UNIVERSIDADE DE SÃO PAULO

FACULDADE DE FILOSOFIA, LETRAS E CIÊNCIAS HUMANAS

DEPARTAMENTO DE LINGUÍSTICA

LEONARDO REITANO

\title{
DISCURSO CONSPIRATÓRIO ONLINE: SANÇÃO E VERIDICÇÃO NOS FÓRUNS DE JOGOS
}

São Paulo 


\section{LEONARDO REITANO}

\section{Discurso conspiratório online: \\ Sanção e Veridicção nos fóruns de jogos \\ Versão original}

Nível: Mestrado

Linha de pesquisa: Análise dos discursos e dos textos verbais expressos na modalidade oral e escrita, e dos textos não verbais Área de concentração: Semiótica e Linguística Geral

Orientador: Prof. Dr. Waldir Beividas

São Paulo

2021 
Catalogado na publicação

Serviço de Biblioteca e documentação

Faculdade de Filosofia, Letras e Ciências Humanas da Universidade de São Paulo 
Nome: REITANO, Leonardo

Título: Discurso conspiratório online: Sanção e veridicção nos fóruns de jogos.

Dissertação apresentada à Faculdade de Filosofia, Letras e Ciências Humanas da Universidade de São Paulo para obtenção do título de Mestre em Semiótica e Linguística Geral.

Aprovado em: $/ 2021$

\section{BANCA EXAMINADORA}

Prof. Dr:

Instituição:

Julgamento:

Assinatura:

Prof. Dr.:

Instituição:

Julgamento:

Assinatura:

Prof. Dr.:

Instituição:

Julgamento:

Assinatura: 


\section{AGRADECIMENTOS}

Agradeço a minha família, Márcia, Reginaldo, Lucas e Odete, por me oferecerem todo o suporte e apoio para a realização deste trabalho, bem como aguentarem minha rotina de escrita. Agradeço também aos parentes que, mesmo não morando comigo, me deram apoio e suporte sempre que precisei, em especial Tia Adriana e Tio Pedro, Ticinho, Marta e Dudu, e meus primos que me ouviram falar sobre meu trabalho durante uma boa parte do nosso reencontro.

Ao Prof. Dr. Waldir Beividas pela elegante orientação e apoio acadêmico: as várias observações e leituras que sempre me ajudaram a evitar que me perdesse nos excessos de minha própria proposta, mas me davam a liberdade para buscar as soluções que mais se adequavam ao projeto.

À USP e ao Departamento de Linguística da FFLCH-USP e todos os servidores que permitiram a viabilização de minha pesquisa. Em especial à Érica, que sempre possuía as respostas para minhas dúvidas.

À Clarissa Monteiro, que foi uma atriz de diversos papéis actanciais durante minha jornada: pelo apoio emocional, pelo auxílio formal com a ABNT e pelo auxílio crítico com a semiótica.

À banca de qualificação, composta pelas prof. Renata Mancini e Paula Martins, pela atenta leitura do projeto, e pelas sugestões que evitaram que minha dissertação se transformasse numa empreitada irrealizável no tempo que eu tinha.

Aos professores Ivã Lopes, Eliane Lima, Norma Discini, Dilson Cruz, Luiz Tatit, Diana Pessoa, Beth Harkot-de-la-Taille, Matheus Schwartzmann, Iara Farias, José Luiz Fiorin e Cristina Altman, pelo apoio acadêmico e administrativo, que fez com que um processo como o mestrado fosse tão agradável e entusiasmante.

Aos colegas de departamento e dos grupos de Whatsapp Les Waldirenes, Les Mancinis, Família GESUSP e RPGesusp: Táriba, Fernando, Joyce, Milton, Marinelli, Vini, Tata, Mafra, Razzino, Mônica, Valéria, Rafa, Bonin, Prachedes, Adriana, Renato, Gizelia, Dan Leite, Ana, Demarchi, Thiago, Maciel, Zeno, Laís, Kalil, Marcelão, Henrique, Hadassa, Cleide, Ernani, Alef, Shimoda, Letícia e Kazuo.

Ao meu amigo Rafael Nascimento, pelo apoio acadêmico, emocional e humorístico. Ao Rodrigo, Paulo, Marília, Freddy, Richie, Shivas, Luiz, Nat Alvarez, Braga, Giga, Nathalia Turri, Barradas, Ghendov, Guilherme, Miranda e Tales por me darem uma vida fora do mundo acadêmico. Ao MarceLab por ser meu professor de $L O L$.

O presente trabalho foi realizado com apoio do Conselho Nacional de Desenvolvimento Científico e Tecnológico (CNPq). Código de Financiamento 130409/2020-0. 


\section{RESUMO}

REITANO, Leonardo. Título: Discurso conspiratório online: Sanção e veridicção nos fóruns de jogos. 2021. 282 f. Dissertação (Mestrado) - Faculdade de Filosofia, Letras e Ciências Humanas, Universidade de São Paulo, São Paulo, 2021.

A presente pesquisa busca lançar luz sobre as relações de usuários de fóruns digitais sobre jogos de videogame com o processo de sanção narrativa e veridicção discursiva. Para atingir tal objetivo, propõe-se inicialmente a análise, dentro dos moldes da semiótica greimasiana, dos dois objetos que compõem o ambiente de fórum: os jogos multijogador $L O L$ e Overwatch, e um conjunto de fóruns utilizados pelos fãs de ambos os jogos. Além da análise individualizada dos elementos do corpus, esta pesquisa enfoca seu estudo também nas relações intertextuais (e hipertextuais) entre esses espaços, pois o sentido dos discursos construídos no espaço de fórum só pode ser compreendido quando se observa os contextos criados entre fórum e jogo. Após o levantamento das principais particularidades do sistema intertextual fórum-jogo, analisar-se-á em detalhes cada uma dessas particularidades: as regras que regem o universo fantasioso, a repetição memética, a preeminência do humor e a densidade da linguagem técnica dentro dos fóruns. A partir dos resultados de tais análises, a pesquisa observa como esses elementos se apresentam dentro do campo da sintaxe e da semântica discursivas, quando sua utilização ad nauseam acaba por se configurar como estratégia discursiva. Em posse dessas estratégias, almeja-se propor um projeto enunciativo, chamado de "discurso conspiratório online": discurso esse que busca uma inviabilização da sanção e utilização da mentira e do segredo como modelos veridictórios principais, impedindo que se julguem ou corrijam os discursos propostos. Argumenta-se por fim que tal estratégia possui laços com as fake news, e os discursos conspiratórios e intolerantes da extrema-direita em ascendência na última década.

Palavras-chave: Fantasia (gênero). Jogos Eletrônicos. Fóruns Digitais. Veridicção. Hipertexto. 


\begin{abstract}
REITANO, Leonardo. Title: Online conspiratorial speech: Sanction and Veridiction in game forums. 2021. 282 p. Dissertation (Master's Degree) - Faculdade de Filosofia, Letras e Ciências Humanas, Universidade de São Paulo, São Paulo, 2021.

This research sheds light upon the relations established between users in online game forums and the processes of narrative sanction and discursive veridiction. In order to achieve such goal, it is first proposed the analysis, within the scope of greimasian semiotics, of two objects that compose the forum environment: the multiplayer games $L O L$ and Overwatch, and also a collection of forums in which players from both games interact. Besides the individual analysis of elements from the corpus, the study of intertextual (and hypertextual) relations between both spaces also comes into focus. Such an approach is justified by the understanding that the meaning of discourses - which are built inside the space of the forum - can only be understood by observing the contexts produced between the online forum and game. After surveying the main particularities of the intertextual system forum-game, these will be analyzed in detail: the rules that govern the fantasy universe, the memetic repetition, the prominence of humor and the density of technical language within the forums. From the results of such analysis, the research observes how these elements present themselves within the field of discursive syntax and semantics, since their recurrent use eventually becomes a discursive strategy itself. Once these elements are accounted for, it is then proposed an enunciative project, named "online conspiratorial discourse": it aims to make the sanction unviable, as to the use of the lie and the secret as main veridiction models, preventing that the proposed discourses are judged or corrected. The final argument of this research proposes that such strategy is related to de development of online fake news, and the intolerant and conspiratorial discourses from the far-right, a common occurrence since the last decade.
\end{abstract}

Keywords: Fantasy (genre). Electronic games. Online forums. Veridiction. Hypertext. 


\section{LISTA DE FIGURAS}

Figura 1 - Esquemático da aproximação entre semiótica e ludologia proposta por Angelo (2015)

Figura 2 - Esquemático da interpretação tensiva proposta por Angelo (2015)............................. 26

Figura 3 - Modelo de análise de jogos proposto por Angelo (2015).

Figura 4 - À esquerda, renderização do cenário de Summoners Rift. À direita, mapa simplificado

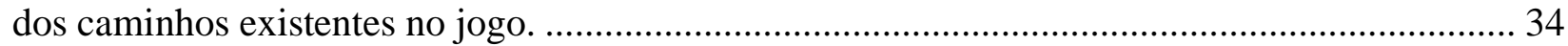

Figura 5 - Divisão em cores dos setores de Summoners Rift. ....................................................... 34

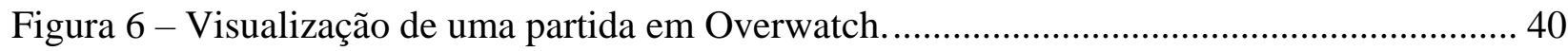

Figura 7 - Comparação das telas de jogo de Overwatch (esquerda) e League of Legends (direita).

Figura 8 - Exemplo do perfil de um campeão em League of Legends........................................... 44

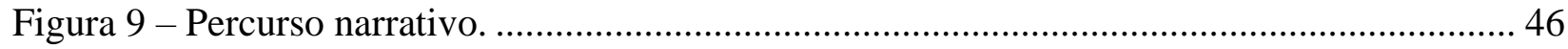

Figura 10 - Gráfico temporal-narrativo baseado no modelo de Juul. …………………............... 53

Figura 11 - Gráfico temporal-narrativo para LOL e Overwatch, baseado no modelo de Juul. .... 54

Figura 12 - Captura de telas de encerramento da partida em LOL................................................5 55

Figura 13 - Captura de telas de encerramento da partida em Overwatch. ...................................... 56

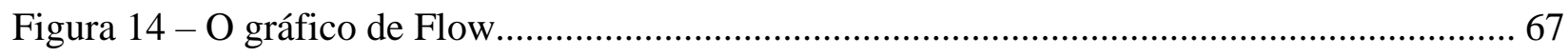

Figura 15 - Tela de seleção de personagens em Super Street Fighter 2 ………………............... 70

Figura 16 - Colagem, representando as nacionalidades das personagens dentro do universo

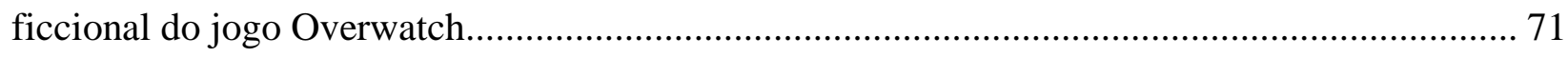

Figura 17 - Mapa de 2017, representando as nacionalidades das personagens dentro do universo

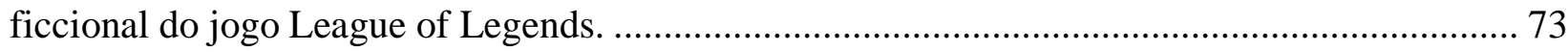

Figura 18 - Algumas skins disponíveis para o campeão Gragas. …………………………….... 80

Figura 19 - Algumas skins disponíveis para a campeã Riven. …………………………………... 81

Figura 20 - Algumas skins disponíveis para o campeão Ryze.................................................... 84

Figura 21 - Modelo de análise semiótica do jogo Overwatch. ..................................................... 88

Figura 22 - Modelo de análise semiótica do jogo League of Legends. ........................................... 90

Figura 23 - Resumo do Percurso Gerativo de Sentido.................................................................... 103

Figura 24 - Apresentação dos percursos temáticos do nível Discursivo. ..................................... 104 
Figura 25 - Apresentação de proposta de distribuição nos percursos temáticos do nível Discursivo.

Figura 26 - Colagem mostrando os perfis de usuário. Em sentido horário: Fandom, Reddit e Rule 34 . 108

Figura 27 - Destacado em vermelho, comentário feito no fórum do Reddit sobre Overwatch. O autor deletou sua própria postagem três dias depois de fazê-la.

Figura 28 - Destacado em vermelho, comentário de um usuário, que foi deletado por um moderador. As interações com o post deletado se mantém.

Figura 29 - Captura de tela do site Reddit, demonstrando os recursos disponíveis na plataforma, destinados a auxiliar a enunciação de seus usuários. 114

Figura 30 - Respostas no modelo de hierarquização visual dos comentários. 116

Figura 31 - Respostas no modelo de citação direta. 116

Figura 32 - Exemplo de post multimídia com comentário escrito. 117

Figura 33 - Exemplo de gif no meio de um comentário. 118

Figura 34 - Colagem exemplificando a sanção qualitativa, assinalada em vermelho. Em sentido descendente: Reddit, Youtube, Fórum de Overwatch e Danbooru. 119

Figura 35 - Exemplo do processo e "edição" da enunciação enunciada como agradecimento à uma sanção positiva.

Figura 36 - Modelo do continuum memético proposto por Marino (2018).

Figura 37 - Meme tipo Sample.

Figura 38 - Meme tipo Remix. 132

Figura 39 - Meme zero-grau do "Boop" de Overwatch. 133

Figura 40 - Memes do tipo Remake. 134

Figura 41 - Exemplo de categorias existentes em fanfics. 138

Figura 42 - Modelo de criação de sentido em imagens proposto por Fraenza (2017). 140

Figura 43 - Captura de tela de jogo, mostrando a personagem D.Va, de Overwatch. 144

Figura 44 - Ilustração da personagem D.Va, de Overwatch. 144

Figura 45 - Ilustração da personagem D.Va, de Overwatch. 145

Figura 46 - Ilustração da personagem D.Va, de Overwatch. 146

Figura 47 - Canal de video-análises de Stylosa. 150

Figura 48 - Quadrinhos feitos por fãs de LOL 152 
Figura 49 - Quadrinhos feitos por fãs de Overwatch e LOL. 154

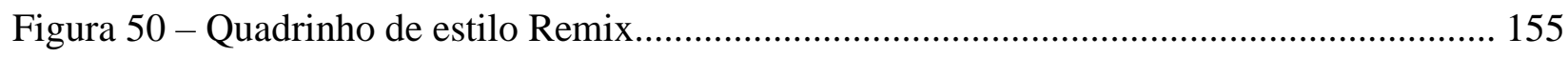

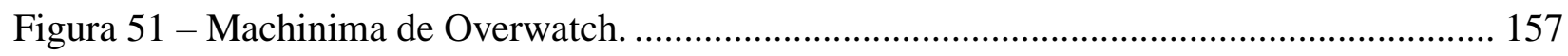

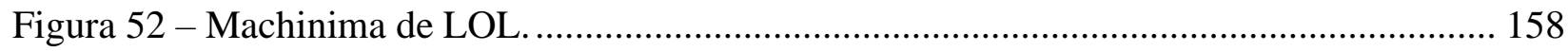

Figura 53 - Lista de competências para a produção de enunciados nas linguagens analisadas.. 162

Figura 54 - Exemplo de ilustração feita através de comissão................................................... 163

Figura 55 - Primeiros comentários no vídeo de lançamento da personagem Sombra................. 165

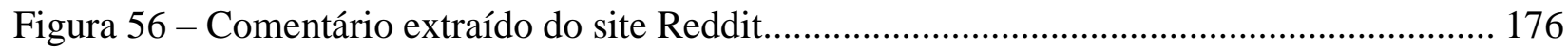

Figura 57 - Comentário extraído do site Youtube. ……………………………………........ 177

Figura 58 - Comentário extraído do site Youtube. ………………........................................ 178

Figura 59 - Comentário extraído do site Reddit................................................................ 179

Figura 60 - Comentário extraído do site Reddit...................................................................... 180

Figura 61 - Postagem no twitter de Michael Chu. .................................................................... 188

Figura 62 - Resposta no Twitter à postagem de Michael Chu.................................................... 189

Figura 63 - Comentários em postagem do site Dambooru. ......................................................... 191

Figura 64 - Comentários em postagem do site Danbooru............................................................. 192

Figura 65 - Resposta no Twitter à postagem de Michael Chu.................................................... 193

Figura 66 - Comentário numa thread do fórum da empresa Blizzard.......................................... 197

Figura 67 - Comentário numa thread do fórum da empresa Blizzard......................................... 198

Figura 68 - Comentário de Twitter e seus respectivos anexos.................................................. 200

Figura 69 - Comentários do site Reddit. .................................................................................. 202

Figura 70 - Descrição de D.Va na wiki de Overwatch. .............................................................. 208

Figura 71 - Ilustrações da personagem D.Va...................................................................... 209

Figura 72 - Ilustrações da personagem D.Va................................................................. 210

Figura 73 - Tags de pesquisa numa imagem apresentando a personagem D.Va....................... 211

Figura 74 - Exemplo de análise sêmica. ...................................................................................... 212

Figura 75 - Análise Sêmica de D.Va (overwatch) e D.Va (gremlin).......................................... 215

Figura 76 - Modelo triforme de linguagem........................................................................ 219

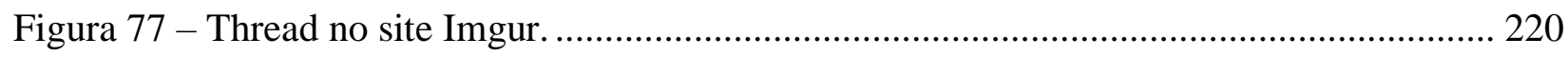

Figura 78 - Análise Sêmica de Seraphine (LOL) ................................................................... 223

Figura 79 - Postagem no Twitter da personagem Seraphine. ………………………............... 226 
Figura 80 - Postagem no Twitter da personagem Seraphine. ........................................... 227

Figura 81 - Postagem no Twitter da personagem Seraphine. .............................................. 227

Figura 82 - Sequência de comentários do site Reddit....................................................... 229

Figura 83 - Ilustração de Deriva Hermética........................................................................ 231

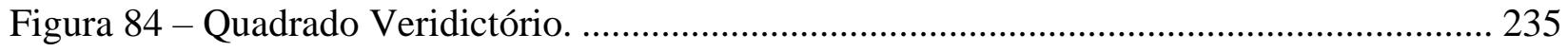

Figura 85 - Modelo veridictório tensivo .................................................................... 237

Figura 86 - Modelo veridictório tensivo aplicado ao objeto de pesquisa. ............................... 241 


\section{SUMÁRIO}

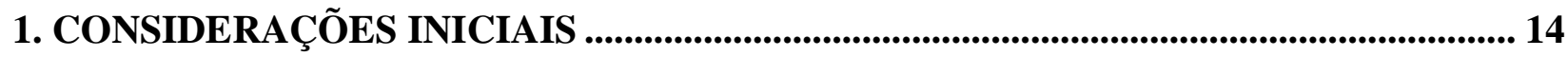

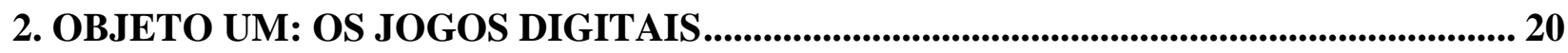

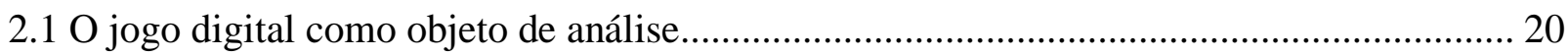

2.2 Um modelo de análise semiótica de jogos .......................................................................... 23

2.3 Apresentação dos objetos............................................................................................... 30

2.3.1 League of Legends (abreviado como LOL) ............................................................. 30

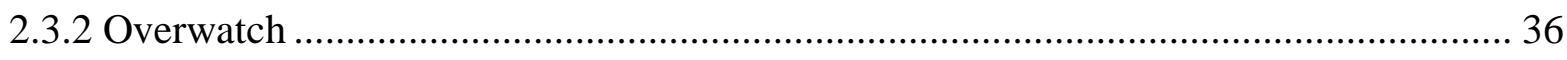

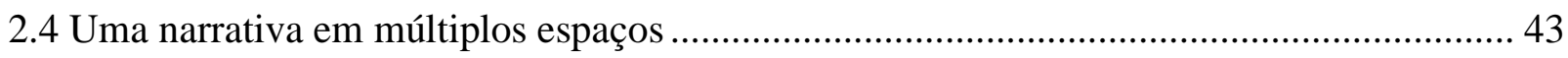

$2.5 \mathrm{O}$ percurso narrativo greimasiano e o corpus analisado ...................................................... 45

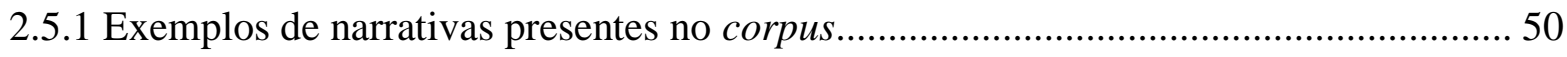

2.5.2 A ausência da sanção nas narrativas do universo ficcional........................................... 53

2.5.3 A rede de equilíbrio do universo ficcional dos jogos.................................................... 60

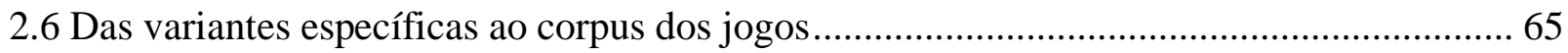

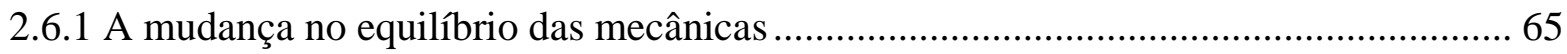

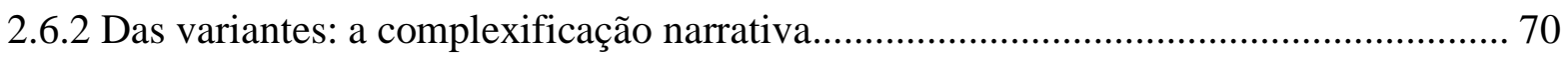

2.6.3 Das variantes: das isotopias propostas pelo elenco de personagens .............................. 74

2.7 Análise de LOL e Overwatch dentro do modelo de análise semiótica de Angelo ............... 88

3. OBJETO DOIS: OS FÓRUNS ...........................................................................................................93

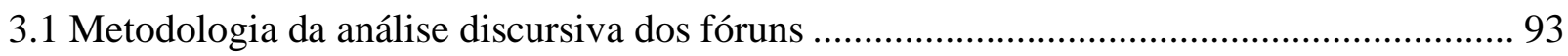

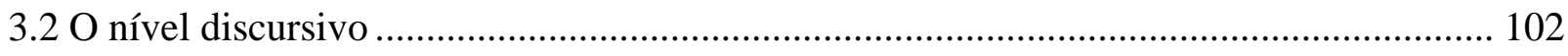

3.3 Os perfis e os comentários ............................................................................................ 108

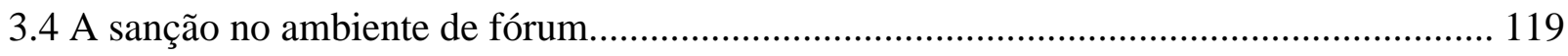

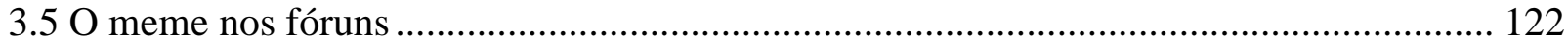

3.6 A sintaxe memética nos fóruns ................................................................................. 130

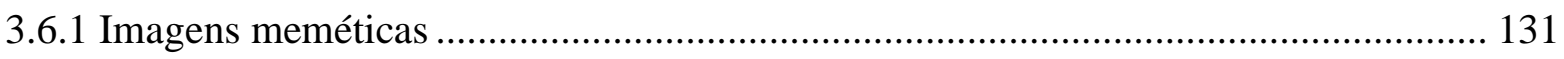




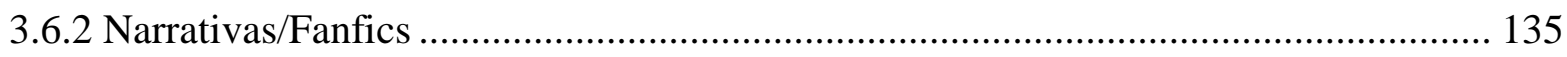

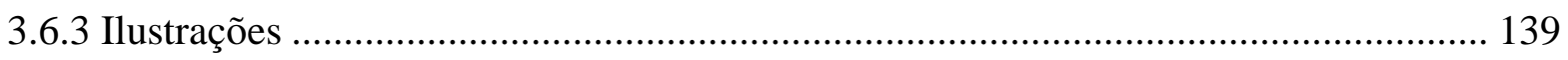

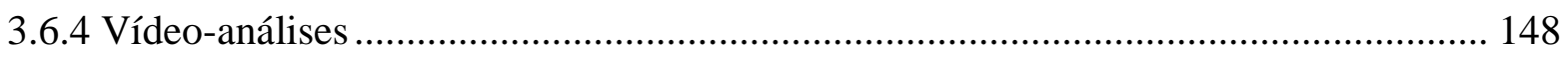

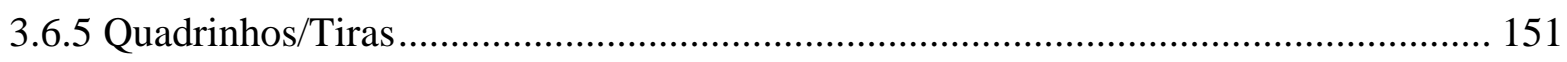

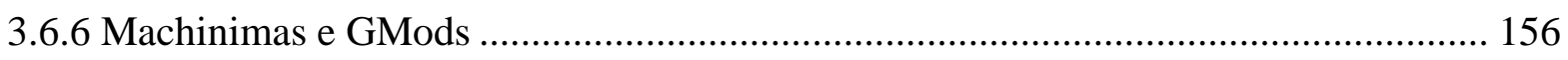

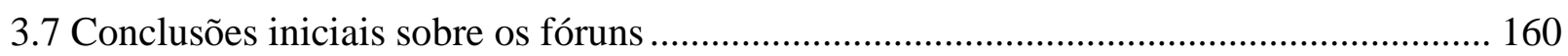

4. OBJETO TRÊS: O MACROTEXTO JOGO - FÓRUM..................................................... 167

4.1 Recapitulação das conclusões iniciais ......................................................................... 167

4.2 Elementos sintáxicos do discurso em fórum................................................................. 171

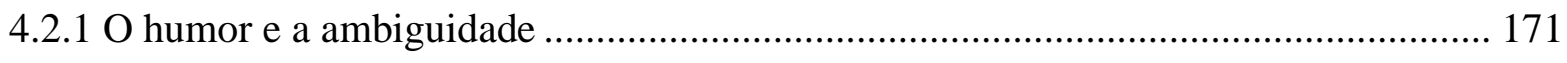

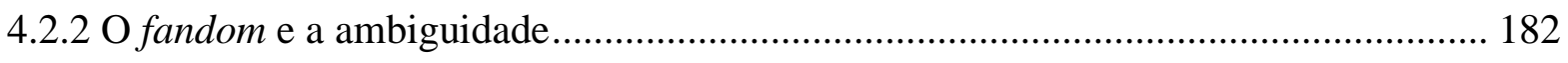

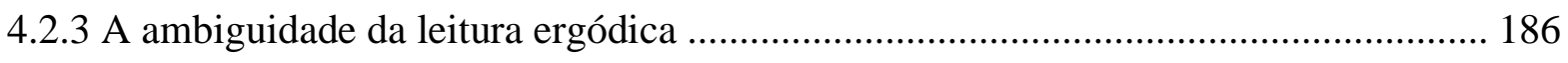

4.2.4 O discurso de autoridade e a conspiração ………………………………………...... 187

4.2.5 - Os pressupostos e a interrupção da discussão ............................................................. 196

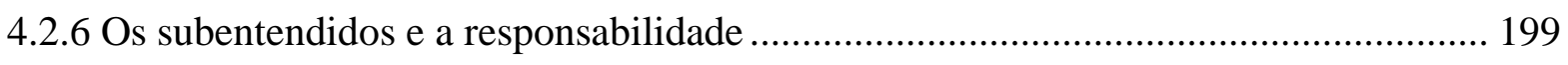

4.2.6 A repetição como estratégia .................................................................................... 204

4.3 Elementos semânticos do discurso em fórum ................................................................ 208

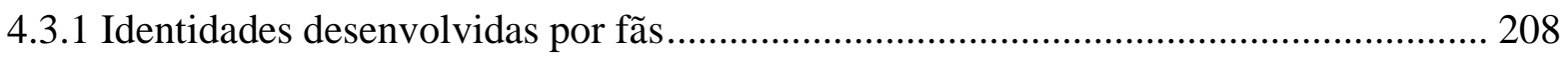

4.3.2 Identidades complexas e compartilhamento de semas .............................................. 212

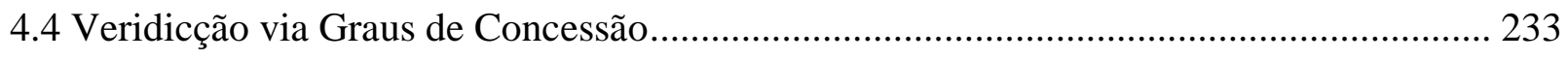

4.4.1 Discurso mentiroso, discurso poético, discurso fantasioso e discurso conspiratório.. 243

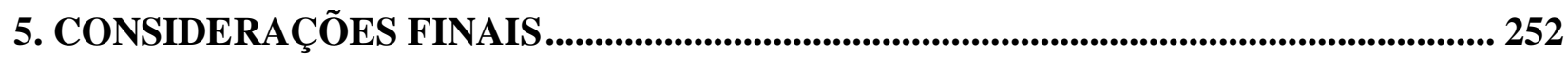

REFERÊNCIAS BIBLIOGRÁFICAS ...................................................................... 260

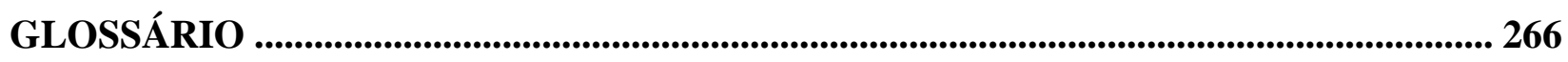




\section{CONSIDERAÇÕES INICIAIS}

A presente pesquisa busca lançar luz sobre as relações de usuários de fóruns digitais dedicados a jogos de videogame e o processo de sanção narrativa e veridicção discursiva.

Para atingir tal objetivo, foi proposta inicialmente a análise, dentro dos moldes da semiótica greimasiana, de um corpus composto por dois espaços típicos do ambiente de fórum: os jogos multijogador $L O L$ e Overwatch e um conjunto de fóruns utilizados por seus fãs.

No capítulo dois, dedicado aos dois jogos de videogame, analisam-se os percursos narrativos de $L O L$ e Overwatch semioticamente, por meio de suas variantes e invariantes. A partir de tal estudo, é possível identificar como elementos comuns da atividade do "jogar": (i) a construção de um universo altamente simbólico e metafórico que, para permitir uma maior interação com os fãs, propõe isotopias conflitantes para simular o efeito de pluralidade de interpretações; (ii) o uso de uma série de personagens de alta carga isotópica que permite a ambos os jogos propor seus universos fantasiosos como "espelhos" do mundo das coisas, no qual todos os elementos simbólicos e culturais desse podem ser metaforizados dentro do universo fantasioso; (iii) a garantia de que as diversas narrativas dentro do universo do jogo não se hierarquizem excessivamente, por meio do constante re-balanceamento de ambos os jogos, tanto narrativa quanto ludologicamente e por fim, (iv) a cristalização dos efeitos de "globalidade" e "igualdade" do jogo, no qual as narrativas do universo fantasioso são incompletas. Neste último, a ausência da etapa da sanção das personagens/sujeitos do jogo mantém todas as várias narrativas e isotopias propostas como virtualmente possíveis, bem como incentivam a interação do fandom, para que esses preencham tais incompletudes.

No capítulo três, dedicado à análise semiótica dos fóruns presentes no corpus, serão levantadas algumas particularidades comuns a todo o conjunto: (i) a estrutura de leitura ergódica, (ii) o intenso uso de tecnoletos, (iii) a utilização de perfis fantasiosos para a interação, (iv) a interação assíncrona, (v) a produção de discursos que invocam diversos suportes audiovisuais simultaneamente, (vi) a necessidade do congelamento de um fluxo de construção discursiva, para que seja possível a análise e, (vii) a utilização de períodos curtos e simulação da fala dentro da escrita. 
Para além da observância dessas particularidades, no capítulo três é proposta também uma forma de organização dos papéis de organização e produção discursiva. Tal organização reforça a noção do macrotexto de enunciador coletivo, composto por pequenos textos de enunciadores, em sua maioria individuais, bem como o caráter coletivo do enunciatário, sendo este "a comunidade" que compõe o fandom.

Além da análise individualizada dos elementos do corpus, os capítulos dois e três enfocam também as relações intertextuais (e hipertextuais) entre esses espaços, pois a presente dissertação propõe que o sentido dos discursos construídos no espaço de fórum só pode ser compreendido pela observância dos contextos criados entre fórum e jogo.

Após levantar as principais particularidades do sistema metatextual fórum-jogo, o capítulo quatro desenvolverá em detalhes as constantes presentes nesse sistema: as regras que regem o universo fantasioso, a repetição memética, a proeminência do humor e a densidade da linguagem técnica dentro dos fóruns.

A partir dos resultados de tais análises, ao fim do capítulo quatro, será observado como esses elementos se apresentam dentro do campo da sintaxe e da semântica discursivas, quando sua utilização ad nauseam acaba por se configurar como estratégia discursiva. Em posse dessas estratégias, esta dissertação almeja, por fim, propor um projeto enunciativo, que será denominado "discurso conspiratório online".

Propõe-se que esse tipo de discurso busca (i) a inviabilização das sanções, (ii) a repetição, (iii) o controle da linguagem técnica, e (iv) uma extensa utilização da mentira e do segredo, como objetivos finais da interação. Nesse ambiente discursivo, os textos e seus argumentos se tornam apenas veículos de um jogo quantitativo de ideologias e crenças. Tais estratégias apresentam laços estruturais com os discursos de Fake News, discursos intolerantes e os chamados "cancelamentos", dentro do ambiente digital.

Os dois jogos abordados por esta dissertação, diferentemente de jogos clássicos como Super Mario World (1990), Street Fighter 2 (1991) e Chrono Trigger (1995), são projetos transmídia, nos quais o universo fantasioso não é construído apenas pelo jogo, mas por uma série de produções em outras linguagens como quadrinhos, animações, hipertextos, etc. Para além da transmidialidade, 
esses jogos são temporalmente durativos: seu "lançamento" pode ser considerado como uma sequência de atualizações de novos conteúdos, que se somam aos conteúdos já existentes. Os jogos do corpus, portanto, possuem um status diferente em relação à sua totalidade: eles nunca serão jogos "completos", pois atualizações serão lançadas, enquanto sua manutenção prosseguir. Tais atualizações, são feitas com o objetivo de agradar o fandom que consome a mídia e, para tanto, são modificações pensadas a partir do que se observa nos fóruns de jogos.

Os fóruns de jogos, por sua vez, são espaços da internet característicos da chamada "Web 3.0" ou "Web Semântica"1, em que a introdução de ferramenta de pesquisa personalizada, bancos de dados e Big Data, permitem que se personalize a experiência do usuário, oferecendo-lhe conteúdos específicos para aumentar seu engajamento emocional com os valores veiculados. A maioria dos fóruns pesquisados possui, em diferentes graus, elementos dessa Web 3.0, e esses elementos acabam por transformar a interação em fórum numa ferramenta de aquisição de capital social.

No decorrer dos últimos anos, certas movimentações dentro de comunidades digitais chamaram a atenção da opinião pública. Um dos primeiros eventos dessa categoria foi o Gamergate, movimento iniciado em 2014, sob a alegação de se tratar de um debate sobre ética na indústria de jogos. O que se identificou, entretanto, foram discussões pautadas em misoginia, teorias conspiratórias e embates ideológicos abstratos, que ignoravam dados reais em prol de interpretações simbólicas.

Exemplos mais recentes desse comportamento são a ascensão e ocasionais eleições de presidentes e outros líderes mundiais, pautados por informações mentirosas, posturas messiânicas e discursos conspiratórios, como Jair Messias Bolsonaro (Brasil, 2018), Donald Trump (Estados Unidos, 2016), Rodrigo Duterte (Filipinas, 2016) e Marine Le Pen (França, 2017). A proeminência

\footnotetext{
${ }^{1}$ WOEBCKEN, Cayo. Web 3.0: conceito, aplicações, e impactos para as empresas. Rock Content. 19 jun. 2017.
} Disponível em: <https://rockcontent.com/br/blog/web-3-0/>. Acesso em: 02 mar. 2021. 
de tais líderes auxiliou ainda o crescimento de comunidades como o QAnon ${ }^{2}$ e o "negacionismo

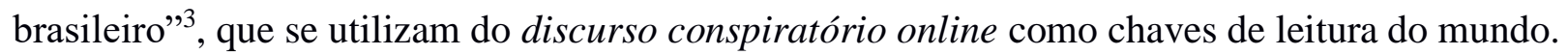

O estudo e análise desses fenômenos é uma iniciativa multidisciplinar: a compreensão dos valores envolvidos tange, para além da semiótica, a antropologia, a sociologia, a economia, entre outras Ciências Humanas. Por outro lado, o universo fantasioso dos jogos de videogame é exclusivamente discursivo e metafórico, portanto, semioticamente privilegiado. Então, a análise do discurso conspiratório online dentro do escopo dos fóruns de jogos digitais é terreno semiótico, no qual as demais ciências podem colaborar-com este campo de conhecimento.

Para além do fato de algumas comunidades de fãs (de esportes, jogos, seriados e outras produções culturais) fazerem parte, de forma intensa, das bases de tais movimentos como o QAnon e similares ${ }^{4}$, é possível supor que certas estratégias de tratamento do discurso - utilizadas por partidários da conspiração e negacionismo - são originárias do espaço de fandom.

A presente pesquisa busca demonstrar que a compreensão do discurso conspiratório online no universo do fandom pode ajudar a lançar luz sobre comportamentos recentes no espaço digital, que desafiam o senso-comum que se faz da "verdade". A invasão ao Capitólio dos Estados Unidos ${ }^{6}$,

${ }^{2}$ WENDLING, Mike. QAnon: O que é e de onde veio o grupo que participou da invasão ao Congresso dos EUA. BBC News Brasil. 07 jan. 2021. Disponível em: <https://www.bbc.com/portuguese/internacional-55577322>. Acesso em 01 mar. 2021.

${ }^{3}$ ROQUE, Tatiana. O negacionismo no poder. Piauí. Fev. 2020. Disponível em: <https://piaui.folha.uol.com.br/ materia/o-negacionismo-no-poder/>. Acesso em: 01 mar. 2021.

${ }^{4}$ CELESTINO, Helena. Jovens 'nerds', 'gamers', hackers e 'haters' formam maior base de apoio a Bolsonaro. Valor Econômico. 11 set. 2020. Disponível em: <https://valor.globo.com/eu-e/noticia/2020/09/11/jovens-nerds-gamershackers-e-haters-formam-maior-base-de-apoio-a-bolsonaro.ghtml>. Acesso em: 01 mar. 2021.

${ }^{5}$ DEBRAN, Dale. Trump, os nerds do 4chan e a nova direita dos Estados Unidos. Tradução: ALLAIN, Clara. Folha de São Paulo. Mar. 2017. Disponível em: <https://www1.folha.uol.com.br/ilustrissima/2017/03/1867370-trump-osnerds-do-4chan-e-a-nova-direita-dos-estados-unidos.shtml>. Acesso em: 01 mar. 2021.

${ }^{6}$ CARROLL Nicole. The Backstory: 'We are done talking' What we witnessed as the presidente of the United States incited a mob of supporters to riot. USA Today. 08 jan. 2021. Disponível em: <https://www.usatoday.com/ story/opinion/2021/01/08/journalists-witness-capitol-riot-trump-supporters-damage/6580244002/>. Acesso em: 01 mar. 2021. 
o ataque às universidades ${ }^{7}$ e o questionamento da vacinação contra a Covid-19 (simultâneo à defesa de tratamentos panacéicos como a Cloroquina ${ }^{8}$ ) são exemplos bem recentes desse descompasso veridictório.

Antes de apresentar, nos capítulos deste estudo, os argumentos para tais afirmações, é importante fazer algumas observações. A primeira delas, sobre o alcance desse discurso conspiratório online: esta pesquisa não propõe que esse tipo de estratégia discursiva seja exclusivo dos círculos de fandom, nem que seja a principal forma interativa dentro dele. A natureza fragmentária e hipertextual do discurso em fórum de jogos, que será abordada em detalhes no item 2.4, dificulta a delimitação de tais estratégias dentro de um suporte ou campo específico. Para esta dissertação, o discurso conspiratório online será um conjunto de estratégias, que não são exclusivas desse tipo de discurso, que se repete dentro do espaço de fórum de jogos, mas não apenas nesses espaços.

Ainda sobre a estrutura hipertextual do fórum de jogos, outra observação importante se refere aos tipos de resultados buscados por esta pesquisa. A presente análise conta com um corpus de 8 fóruns e 2 jogos: a abordagem analítica de tal corpus se concentra nas relações contextuais entre o sistema fórum-jogo, ao ponto de propor que tal sistema é um "macrotexto" coletivo, composto por diversos textos menores. Tal abordagem e extensidade de corpus não são pontos pacíficos dentro dos cânones de análise semiótica, fazendo com que críticas e divergências sejam esperadas.

Em função da heterodoxia da proposta, esta pesquisa escolheu uma abordagem mais abrangente, identificando os contornos gerais e a recorrência das estratégias discursivas do corpus como um todo, em vez de um corpus menor com análises mais detalhadas das estruturas semióticas presentes. Com tal abordagem, não se pretende apresentar exemplos cristalizados de interações,

\footnotetext{
${ }^{7}$ KER, João. Os ataques de Weintraub às universidades da "balbúrdia”. Terra. 10 fev. 2020. Disponível em: <https://www.terra.com.br/noticias/educacao/os-ataques-de-weintraub-as-universidades-dabalburdia,c5f4988ad50a620e0cf0b0915a9272d6gcjhx8ci.html>. Acesso em: 01 mar. 2021.

${ }^{8}$ BRITO, José. Enquanto recusava vacina, Ministério da Saúde entregava cloroquina a estados. CNN Brasil. 06 fev. 2021. Disponível em: <https:/www.cnnbrasil.com.br/saude/2021/02/06/enquanto-recusava-vacina-ministerio-dasaude-entregava-cloroquina-a-estados>. Acesso em: 01 mar. 2021.
} 
mas as linhas gerais de um projeto enunciativo, de recorrência dentro dos fóruns sobre jogos digitais. A possibilidade de estender tais resultados a outros campos será discutida mais profundamente nas considerações finais. 


\section{OBJETO UM: OS JOGOS DIGITAIS}

\subsection{O jogo digital como objeto de análise}

Os jogos digitais, que se utilizam de componentes eletrônicos, não possuem, em termos cronológicos, uma história muito longa se comparado com outras tecnologias. No decorrer dos anos 1950, surgiram as primeiras emulações de jogos tradicionais como damas ou o jogo-da-velha, que serviam principalmente como entretenimento para os visitantes que iam conhecer os novos “computadores do futuro" em feiras e excursões 9.

Em 1962, surge o Spacewar!, programa criado por estudantes do MIT, que é o primeiro jogo que pode ser transferido de um computador para o outro, eliminando a dependência do jogo em relação ao hardware onde foi criado. A partir deste ponto, a jornada para a popularização dos jogos de videogame seria uma questão de tempo ${ }^{10}$.

Apesar de seu curto histórico em relação a outras linguagens, como o cinema, a literatura escrita ou o teatro, os pesquisadores de jogos de videogame se utilizam de teorias produzidas pelos estudiosos dos jogos analógicos ${ }^{11}$. A área da Ludologia, termo cunhado pela primeira vez por Mihaly Csikszentmihalyi, em um artigo de $1982^{12}$, possui trabalhos que datam desde os anos 1930, com destaque para as obras pioneiras de Johan Huizinga (Homo Ludens - 1938) e Roger Caillois (Man, Play and games - 1958).

\footnotetext{
${ }^{9}$ SMITH, Alexander. The priesthood at play: computer games in the 1950s. They create worlds. Disponível em: <https://videogamehistorian.wordpress.com/2014/01/22/the-priesthood-at-play-computer-games-in-the-1950s/>. Acesso em: 09 jan. 2020.

10 SMITH, Alexander. One, two, three, four, I declare a space war. They create worlds. Disponível em: <https://videogamehistorian.wordpress.com/2014/08/07/one-two-three-four-i-declare-a-space-war/> Acesso em: 10 de jan. 2020.

11 Não confundir os estudos sobre jogos que estamos abordando com a Teoria dos Jogos, utilizada modelos matemáticos para a tomada de decisões econômicas.

12 JUUL, Jesper. The definitive history of games and stories, ludology and narratology. The Ludologist. Disponível em: <https://www.jesperjuul.net/ludologist/2004/02/22/the-definitive-history-of-games-and-stories-ludology-andnarratology/>. Acesso em: 10 jan. 2020.
} 
É importante apontar que não apenas os pesquisadores de videogames se valeram dos estudos sobre o jogo, mas a Ludologia foi abordada por muitas áreas de pesquisa. Nas primeiras linhas de Homo Ludens, o autor postula que:

mesmo em suas formas mais simples, ao nível animal, o jogo é mais do que um fenômeno fisiológico ou um reflexo psicológico. Ultrapassa os limites da atividade puramente física ou biológica. É uma função significante, isto é, encerra um determinado sentido. No jogo existe alguma coisa 'em jogo' que transcende as necessidades imediatas da vida e confere um sentido à ação. (HUIZINGA, 2014, p 3-4)

Ao observar a distribuição de capítulos que compõe o Homo Ludens de Huizinga, se encontram títulos como "O jogo e a guerra", "O jogo e o Conhecimento" ou "Formas lúdicas da Filosofia", que confirma um dos postulados da Ludologia, de que:

a verdadeira civilização não pode existir sem um certo elemento lúdico, porque a civilização implica a limitação e o domínio de si próprio, a capacidade de não tomar suas próprias tendências pelo fim último da humanidade, compreendendo que se está encerrado dentro de certos limites livremente aceites. De certo modo, a civilização sempre será um jogo governado por certas regras, e a verdadeira civilização sempre exigirá espírito esportivo, a capacidade de fair play. $\mathrm{O}$ fair play é simplesmente a boa-fé expressa em termos lúdicos. (HUIZINGA, 2014, p 234)

Com este ideal do jogo como um elemento que pode estar presente em diversos campos humanos, e portanto passível tanto de análise de suas práticas como da utilização destes jogos como metáforas, diversos pensadores se utilizaram destas práticas no decorrer da história das ciências. Em 1980, A.J. Greimas publicou “Á propos du jeu” na Actes Semiotiques - Documents No.13 (que no Brasil foi publicado como “Acerca do Jogo", traduzido por Jean Cristtus Portela e presente na revista Significação - Revista de Cultura Audiovisual, Vol. 34 - No. 27, de 2007). Nesta publicação, o autor argumenta que “...Husserl, Saussure, Wittgenstein, Hjelmslev - em algum momento, tomaram o jogo - e mais particularmente o jogo de xadrez - como modelo para sua reflexão" (GREIMAS, 2007, p. 14).

Greimas defende nesse texto que tal emprego metafórico do jogo não é um acaso, mas "se inscreve profundamente, na episteme profunda do século. Refletir sobre o jogo é, para nós, refletir sobre a linguagem e, de uma forma mais abrangente, sobre nossa maneira de ser no mundo significante” (2007, pág. 14). Apesar da análise de Greimas trazer muitas questões interessantes, que serão posteriormente abordadas no decorrer deste capítulo, o primeiro ponto do texto abordado 
nesta pesquisa é, na verdade, uma análise que, no futuro, se revela insuficiente. Ao analisar os casos dos embates de xadrez entre homem e máquina, a partir da capacidade do computador de entender e interpretar os diversos percursos narrativos de um jogador humano pode desenvolver para vencer o jogo e enganar o adversário, o autor afirma que:

A máquina operando, em um primeiro tempo, no nível "referencial" do jogo não seria capaz de interpretar os programas lúdicos que não fossem fundados na busca da vitória, mas regidos pelo sistema modal de segundo grau que produz configurações de jogo que não significam aquilo que parecem querer significar (GREIMAS, 2007, pag. 17).

Nas notas de rodapé da publicação brasileira o próprio tradutor, Jean Cristtus Portela, percebe a inconsistência na visão de Greimas sobre computadores, argumentando que

...a visão greimasiana revela sua acuidade na distinção que sugere entre inteligência humana e artificial, que repousaria no fato de a inteligência humana ser sobredeterminada por um sistema modal subjetivo, instável pois desejante, [...] ao passo que a máquina, cartesiana, limitada pela não-contradição, só conheceria o rigor do /dever/. (PORTELA, 2007, pag. 18)

A análise greimasiana se viu desafiada pelos próprios desenvolvimentos históricos, como a vitória do computador Deep Blue sobre o enxadrista Gary Kasparov em 1997 (mas devemos compreender que Greimas estava, à época, prevendo os desenvolvimentos da computação, com os dados que eram possíveis de serem acessados em 1980), que punham em xeque a afirmação de que a inteligência humana e a programação da máquina teriam comportamentos de interpretação narrativa opostos, cabendo apenas ao primeiro a capacidade de se adequar à dinâmica dos sistemas lúdicos da busca simultânea pela vitória e pela enganação do adversário. Entre as visões diferentes da apresentada por Greimas, encontra-se a do pesquisador norueguês Espen Aarseth, estudioso de jogos digitais e linguagem que, ao analisar a complexidade da linguagem processada pelo computador, afirma que "Quando um sistema é suficientemente complexo, ele vai, por intenção, erro, ou coincidência, inevitavelmente produzir resultados que não foram previstos nem pelo desenvolvedor do sistema” (AARSETH, 1997, p. 27, tradução nossa). 


\subsection{Um modelo de análise semiótica de jogos}

Para diminuir a chance de incorrer em equívocos similares sobre a interpretação de jogos sob a metodologia semiótica, e trazendo para nosso referencial desenvolvimentos teóricos mais atuais na área da computação, esta pesquisa utilizará como modelo de análise a dissertação de José Romero Cardozo Angelo, apresentada em 2015 na UFF (Universidade Federal Fluminense) e intitulada “Análise Semiótica de Videogames: Uma aposta na interdisciplinaridade”.

Neste trabalho, Angelo propõe um modelo semiótico de análise de jogos, desenvolvido a partir dos conceitos de sincretismo do linguista dinamarquês Louis Hjelmslev, da semiótica tensiva do semioticista francês Claude Zilberberg e dos estudos sobre as dinâmicas dos videogames do ludologista dinamarquês Jesper Juul. Angelo utiliza os dois primeiros capítulos de sua dissertação para tratar apenas da aproximação teórica e metodológica entre os campos da ludologia e da semiótica narratológica, bem como os jogos que compõe o seu corpus de análise são jogos que exploram e exemplificam os desenvolvimentos principais da área dos videogames.

A abordagem e metodologia escolhidas por Angelo deram à presente pesquisa um ponto de partida para a elaboração de análise semiótica dos jogos que integram seu corpus.

A aproximação das áreas da ludologia e da semiótica é resumida por Angelo na seguinte tabela:

Figura 1 - Esquemático da aproximação entre semiótica e ludologia proposta por Angelo (2015) 


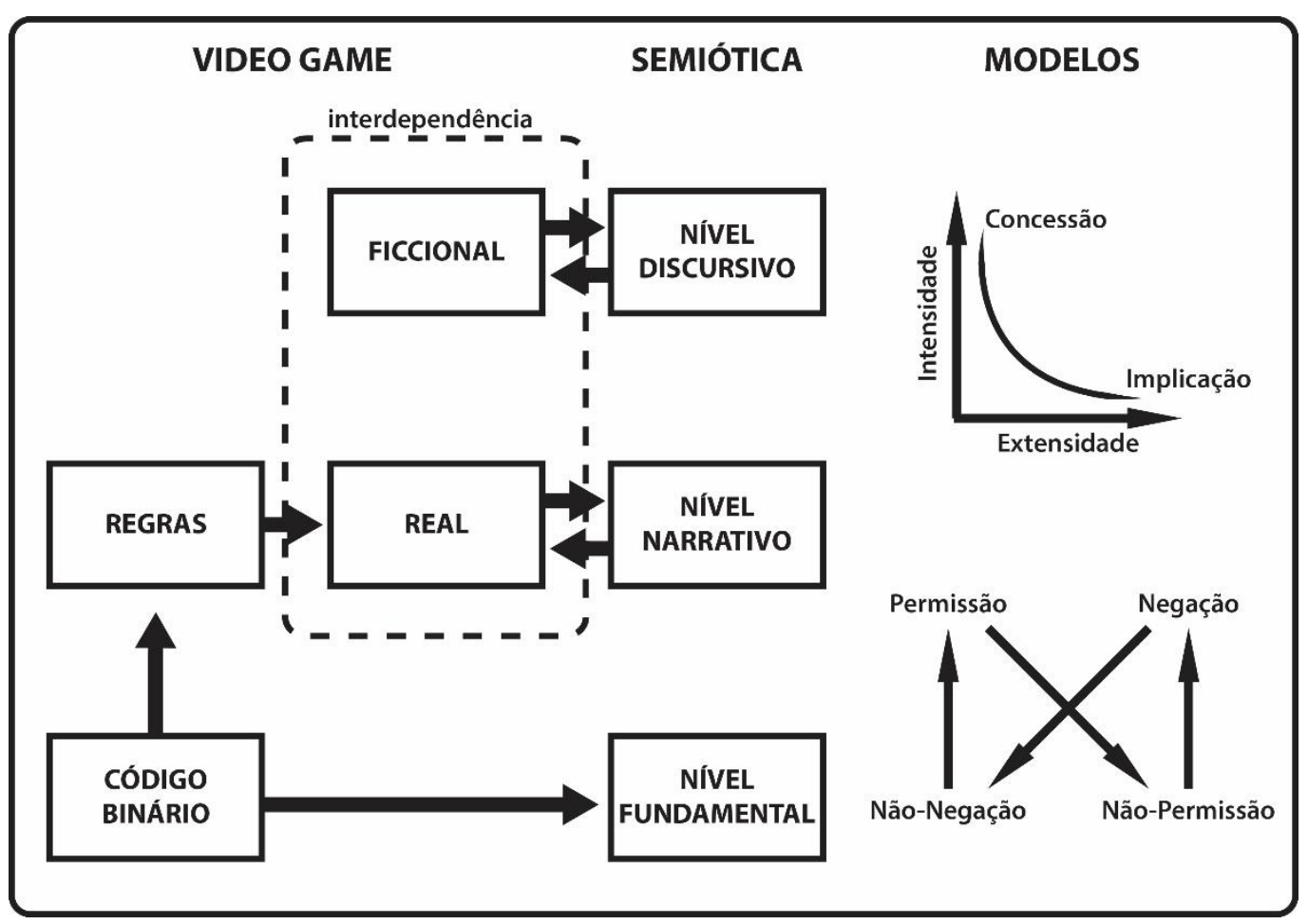

Fonte: imagem nossa, adaptada de Angelo (2015).

No modelo desta figura, o autor postula que existe uma interdependência entre o universo "real" e "ficcional" do videogame, onde o "real" é a ação do jogador sobre o jogo a partir de regras definidas, e o "ficcional" é o recobrimento figurativo que apenas funciona em conjunto com as regras, pois:

...há uma interdependência entre eles - o ficcional recobre um conjunto de possibilidades previstas pelas regras e estas, por si só, representam um ato de imaginação. É o entendimento proporcionado pela abstração de regras que permite a um grupo de pessoas adotarem procedimentos específicos ao jogar. Desta forma, ignorar o recobrimento figurativo proporcionado pela parte ficcional do jogo é desconsiderar a relação entre o jogador e os elementos projetados. (ANGELO, 2015, p. 32).

Os componentes "reais" estão presentes na camada narrativa do percurso gerativo de sentido desenvolvido por Greimas, são as regras por onde o jogador, figurativizado pela personagem protagonista, conseguirá chegar à conjunção com o objeto de seu programa narrativo (geralmente a vitória, com diversos recobrimentos figurativos). Os componentes "ficcionais" por sua vez, estão ligados à camada discursiva do percurso gerativo greimasiano, pois são as escolhas de recobrimento figurativo do jogo e suas modificações no decorrer da narrativa que ajudam a 
modalizar o jogador com os quereres, poderes e saberes necessários para cumprir o programa narrativo $^{13}$; bem como explicitam as escolhas críticas e ideológicas impressas na história do jogo.

Ainda referente à aproximação entre o percurso gerativo e a ludologia, Angelo relaciona o nível fundamental do percurso, onde são analisadas as oposições axiológicas que estruturam os demais níveis, com a natureza binária da lógica de um computador, que opera um código binário de valores " 0 " e " 1 ":

No caso do videogame, trabalhamos com uma alternância não gradativa entre permissão e proibição [...] a não-permissão implica a proibição; a não-proibição, a permissão. O binarismo está presente na lógica de programação de todas as alternativas testadas pelo videogame, como, por exemplo, utilizar ou não determinado armamento ou vestuário [...] Ações como atacar ou defender, andar ou correr, pular ou rolar, por exemplo, integram esse universo de escolhas. (ANGELO, 2015, p. 105).

No canto inferior direito da Tabela 1 se encontra o modelo do quadrado semiótico proposto por Angelo em sua análise. A multiplicação dos comandos de lógica binária acaba por constituir as regras do jogo, que por sua vez compõem o nível narrativo deste percurso gerativo de sentido. Angelo propõe ainda que a aproximação semiótica do estudo da ludologia pode se beneficiar da abordagem tensiva, idealizada por Claude Zilberberg.

Ilustrado pelo gráfico no canto superior direito da Tabela 1, a abordagem tensiva proposta por Angelo postula que as regras do jogo são apresentadas numa lógica implicativa "se X - então Y”, e são administradas pelo jogador para a modalização de sua personagem com os saberes e poderes necessários para vencer o programa-base do jogo. Para superar novos desafios encontrados no decorrer do jogo, o jogador deve manejar as regras conhecidas, e guiar-se através das figuras apresentadas pela narrativa, para compreender novas lógicas concessivas “embora $\mathrm{X}$ - ainda assim Y” e superar da maneira mais fácil os novos desafios.

\footnotetext{
${ }^{13}$ Vale dizer que o recobrimento figurativo é o principal elemento que os fãs e jogadores consideram quando se unem em comunidades (fandoms), pois jogos com mecânicas similares podem atrair públicos distintos, assim como o contrário também ocorre. Porém este recobrimento, apesar de ser o mais proeminente, não é o único a contribuir para tal escolha, já que os gêneros de jogos, marcados por conjuntos de regras específicas, também atraem jogadores que tenham preferência por certos tipos de desafios, proporcionados por certos tipos de regras.
} 
Aplicando esta lógica dentro do grafo tensivo de Zilberberg, o eixo vertical (Intensidade Concessão) exemplifica a dinâmica do aprendizado para a superação do desafio: ao ser defrontado com o desafio, o jogador deve descobrir uma nova configuração dos seus conhecimentos sobre o jogo a partir de sua interação com as figuras dentro na narrativa, e isto gera uma maior intensidade na sua percepção do jogo. Já no eixo horizontal (Extensidade - Implicação) está a dinâmica da regra: o jogador conhece as mecânicas necessárias para avançar, portanto sua percepção do jogo está mais extensa, ou seja, relaxada. No decorrer do jogo, o jogador percorre entre estes dois eixos, de acordo com as dificuldades encontradas.

O grafo tensivo de Zilberberg ganha ainda uma segunda forma, mais detalhada, onde Angelo insere as considerações feitas na relação entre semiótica e ludologia dentro do modelo tensivo, como mostrado a seguir:

Figura 2 - Esquemático da interpretação tensiva proposta por Angelo (2015).

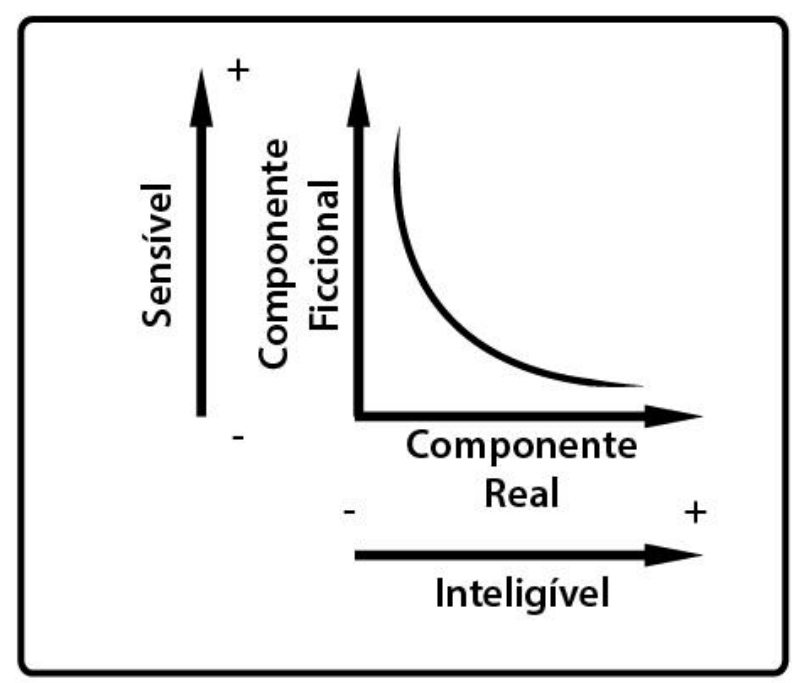

Fonte: imagem nossa, adaptada de Angelo (2015).

Neste grafo, Angelo propõe que, quando a narrativa do jogo por algum motivo aumenta a tensão (seja introduzindo novos inimigos, desafios, ou desenvolvendo a narrativa para fornecer ao jogador novas modalizações ou atualizações em seus programa-base ou programas de uso), a dimensão sensível sobressai, e os componentes "ficcionais", descritos pelo autor como os recobrimentos figurativos, passam a ser privilegiados. Já quando a narrativa se encontra num estágio de administração das regras e competências já adquiridas, a tensão diminui e o jogo se torna mais inteligível, permitindo que os componentes "reais", descritos por Angelo como as regras que regem o jogo, tomem o primeiro plano na atenção do jogador. 
O autor afirma ainda que "Na proposta do modelo tensivo, a intensidade rege a extensidade. De forma análoga, para a teoria do videogame, apesar de o real sustentar o ficcional, este é a variável regente" (ANGELO, 2015, p. 109). Ou seja, é a dimensão da figurativização, e o aumento e diminuição na tensão da narrativa, que permite às regras sobressaírem para o jogador ou não.

Por fim, Angelo propõe um modelo de análise, para que as observações feitas por ele possam ser utilizadas para nortear análises semióticas em que o objeto seja um jogo de videogame. O modelo se apresenta da seguinte forma:

Figura 3 - Modelo de análise de jogos proposto por Anḡelo (2015).

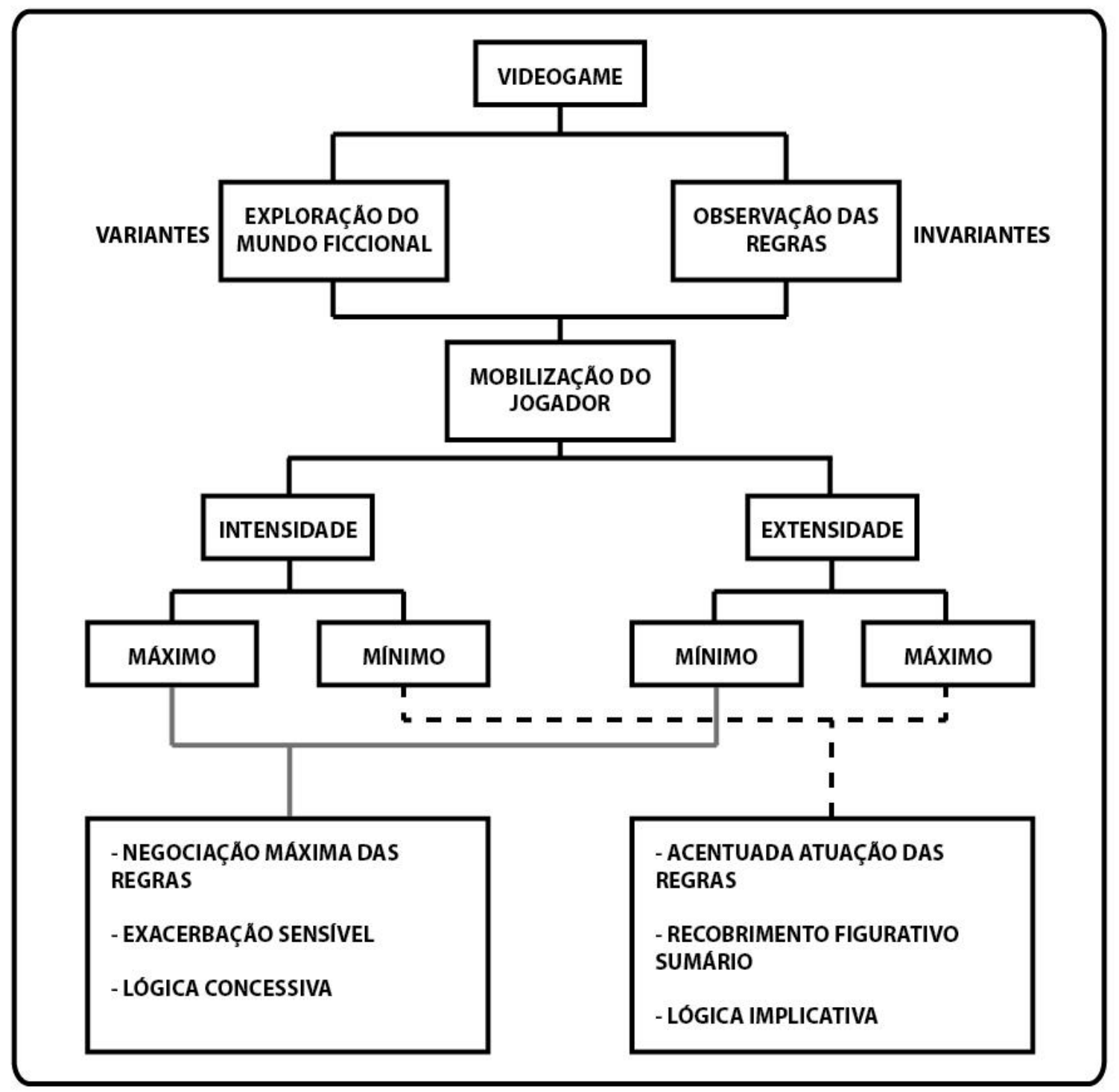

Fonte: imagem nossa, adaptada de Angelo (2015). 
Angelo afirma que a análise do jogo deverá partir de "variantes" e "invariantes" que compõem a experiência e a mobilização do jogador. As invariantes serão geralmente estruturadas pelas regras, tanto implicativas quanto concessivas, presentes na programação do jogo, já que estas regras serão aplicadas igualmente a todos os jogadores, contanto que certos pré-requisitos sejam atingidos. As variantes serão estruturadas pela exploração do mundo ficcional, o modo como os jogadores combinam os elementos do jogo e a ordem em que realizam os programas de uso disponíveis.

Note-se que certas regras podem ser invariantes, como por exemplo nos casos de evolução dos poderes do protagonista, em que o jogador deve escolher entre duas novas habilidades modalizadoras distintas, em que a habilidade escolhida passará a ser uma nova regra dentro do sistema do jogo.

Igualmente, elementos do mundo ficcional podem ser também invariantes, como por exemplo algum desenvolvimento da narrativa que impreterivelmente deverá acontecer durante a experiência do jogador. A linha divisória mais constante entre as variantes e invariantes é a ação do jogador: No caso das variantes, a ação do jogador resulta diretamente nos acontecimentos, enquanto no caso das invariantes, os acontecimentos são gatilhos, armados como reação às ações do jogador.

No passo seguinte da análise, Angelo propõe que se estruture os elementos principais dentro dos dois extremos do grafo tensivo: o momento de alta intensidade/baixa extensidade e o momento de baixa intensidade/alta extensidade. No primeiro momento, a mobilização do jogador é norteada pela negociação máxima das regras (lógica concessiva) e pela predominância do sensível, enquanto, no segundo momento, a mobilização é de uma acentuada aplicação das regras (lógica implicativa) e pouca interferência do recobrimento figurativo. Esta estrutura permite reconhecer quais acontecimentos no jogo são relacionados com cada um dos tipos de lógica.

A escolha pela utilização do modelo de análise desenvolvido por Angelo se explica por dois principais fatores: atualidade e consideração pela linguagem digital. O uso do seu modelo se mostra portanto adequado para esta pesquisa não apenas por que é feita sob a luz dos mais recentes desdobramentos da semiótica Greimasiana, mas por que, ao levar em conta no percurso gerativo de sentido a lógica que rege o computador e os videogames como um todo, o autor não incorre na 
mesma carência apontada por Portela, na análise do jogo de computador feita por Greimas em 1980 e citada acima.

Tal iniciativa também compreende uma crítica feita por Aarseth a respeito da insuficiência da semiótica, na época, ao abordar textos digitais:

Quando a relação entre o signo da superfície e o usuário é tudo o que importa, a singular materialidade dual do processo do signo cibernético é ignorada. Sem o entendimento da dualidade, porém, a análise do fenômeno de comunicação envolvendo a produção de signos cibernéticos se torna superficial e incompleta (AARSETH, 1997, p. 40 - tradução nossa).

Por dualidade, Aarseth se refere ao fato de que, para a construção da interface com a qual o jogador interage há, no nível do código do jogo, uma construção signica que é visível apenas quando o jogo está ativo, porém ela é o que possibilita a construção da própria camada interativa da interface. Os princípios das "regras" e "recobrimentos" do modelo de Angelo ajudam a sanar esta carência, descrita por Aarseth. Após a apresentação do modelo de análise dos jogos, esta pesquisa apresentará agora os jogos que serão analisados. 


\subsection{Apresentação dos objetos}

Esta pesquisa utilizará dois jogos de videogame como o corpus principal:

\subsubsection{League of Legends (abreviado como LOL)}

Desenvolvido pela empresa estadunidense Riot Games, lançado em 2009, LOL é um jogo de videogame freemium disponível para PC. Este jogo é considerado o e-sports mais assistido no mundo, possuindo campeonatos regionais no Brasil, Europa, Rússia, China, Coréia do Sul, América do Norte, Japão, América Latina, Oceania, Turquia, Vietnã, bem como finais mundiais; a edição de 2019 da final foi acompanhada por 44 milhões de pessoas ${ }^{14}$.

O modo de jogo mais comum dentro de LOL é chamado Summoners Rift, onde dois times de cinco jogadores se enfrentam em partidas com duração média de meia hora. Para uma partida, cada jogador deve escolher uma das personagens existentes no jogo. Estas personagens são chamadas de campeões e o número total de campeões disponíveis é de 154 opções até janeiro de $2021^{15}$. Além do recobrimento figurativo do avatar que o jogador utilizará no jogo, os campeões disponíveis diferenciam-se pelos seus atributos, como por exemplo a quantidade de pontos de vida e "mana"16 que cada campeão possui, e seus respectivos kits de habilidades.

No tangente às habilidades, cada campeão possui cinco tipos de habilidades diferentes . Como o número de habilidades de todos os campeões somados passam de setecentas, há certas

\footnotetext{
${ }^{14}$ HEATH, Jerome. The 2019 League of Legends worlds finals peaked at 44 million viewers. Dot Esports. 17 dec. 2019. Disponível em: <https://dotesports.com/league-of-legends/news/league-of-legends-2019-worlds-peakviewership> Acesso em: 10 jan. 2020.

15 Periodicamente, para incentivar o fandom e promover atualizações no balanço do jogo, os desenvolvedores adicionam novos campeões às opções do jogador. No caso de $L O L$, a média é que a cada ano sejam apresentados de três a quatro novos campeões.

16 "Mana" neste caso é uma acepção mais recente do termo. Descrito pela primeira vez por R.H Codrington e citado por James Frazer no seu Ramo de Ouro, originalmente se refere a um poder invisível que certas civilizações acreditavam ser a causa de efeitos que transcendem a concepção regular da natureza, e que habitavam em espíritos e nos seres vivos, impregnando inclusive as coisas que pertenciam a eles. $\mathrm{O}$ termo foi adotado por muitos desenvolvedores de jogos (League of Legends, Magic the Gathering, etc.) para nomear a energia genérica, quantificável e renovável que a personagem do jogador utiliza para lançar magias ou utilizar toda a sorte de habilidades sobrenaturais.
} 
redundâncias entre habilidades de campeões distintos: por exemplo a habilidade do campeão Nautilus, chamada "Ira do Titã" e a habilidade do campeão Malachite, chamada "Escudo de granito" possuem a mesma mecânica dentro do jogo (criam uma “cobertura" sobre o campeão, aumentando temporariamente sua resistência aos ataques inimigos), porém seus custos, tempo de duração e porcentagem de absorção do dano recebido variam. A partir disso, pode-se afirmar que, enquanto as habilidades em si não são únicas, pois há limitações em quantos efeitos podem ser criados na mecânica do jogo, não há habilidades idênticas, e cada campeão possui um kit de habilidades único.

Após escolhidos os respectivos campeões, a dinâmica do jogo é a de ataque à base adversária: cada um dos dois times possui um "totem"17 que servirá como a sua base, que é chamada de Nexus dentro do jogo. Os "totens" ficam posicionados em lados opostos da arena. O objetivo de cada time é derrubar as defesas adversárias (chamadas torres, inibidores e tropas) bem como as criaturas selvagens que se encontram espalhadas no mapa e, então, destruir o "totem" adversário, enquanto simultaneamente defende seu próprio "totem" do time adversário. O primeiro time a destruir o "totem" da outra equipe, vence. Para auxiliar neste objetivo, cada jogador pode adquirir melhorias para seu campeão, e para isso ele deve acumular pontos de experiência (chamado de $X P$ dentro do jogo) e dinheiro (chamado de Ouro dentro do jogo). Tanto o ouro quanto o XP podem sem adquiridos derrotando campeões adversários, torres, inibidores, criaturas ou tropas em combate. O ouro acumulado pode ser utilizado no "Totem" do time, para a compra de itens, enquanto o XP é acumulado e utilizado dentro da própria janela que mostra os atributos do campeão.

Os papéis e tarefas com os quais cada jogador de um time é incumbido durante a partida varia em função do tipo de campeão escolhido e de sua posição no mapa. As variações nos tipos de campeões disponíveis são chamadas de Funções, enquanto sua posição no mapa, é chamada de Rota. Em $L O L$ existem sete funções nas quais um herói pode se encaixar:

\footnotetext{
${ }^{17}$ Neste caso, a palavra “totem" é colocada entre aspas pois estamos nos referindo apenas à sua acepção mais genérica, proposta por Frazer, de um receptáculo no qual um homem mantém sua vida. Esta definição está de acordo com sua função dentro dos modos de jogo analisados, onde a proteção e manutenção do Totem garante a vitória do jogador sobre seu adversário. Este uso não inclui a totalidade dos sentidos sociológicos e psicológicos descritos nos trabalhos por exemplo de James G. Frazer, Émile Durkheim ou Sigmund Freud.
} 
1. Retalhadores: Campeões cuja principal característica é uma rápida mobilidade pelo cenário, e possuidores de ataques rápidos e com grande dano. Em contrapartida, são campeões com pouca resistência, podendo ser eliminados rapidamente. Podem ser especialistas em combate individual (duelistas) ou ataques furtivos (assassinos).

2. Atiradores: Campeões que podem infligir grandes quantidades de dano à distância, porém que possuem mobilidade e resistência baixos, necessitando do apoio de aliados para não ser eliminados rapidamente.

3. Lutadores: Os Campeões lutadores têm como característica principal infligir dano constantemente nos adversários. Possuem bom poder ofensivo, boa resistência e boa mobilidade, porém por serem funções que costumam estar na frente de batalha, costumam ser alvos fáceis dos ataques adversários e suas habilidades incapacitantes. Podem ser especialistas em resistência durante seus ataques (colossos) ou em rápidos ataques de grande dano (lutadores de investida).

4. Magos: Campeões especializados em feitiços, capazes de atacar e atrapalhar os inimigos e alterar as condições do campo de batalha. Como os retalhadores, são campeões com pouca resistência. Podem ser especialistas em magias de dano (obliteradores), em manipulação dos status no campo de batalha (magos de batalha) ou em infligir ataques constantes nos adversários (artilharia).

5. Suporte: São campeões especializados em dar suporte a outros jogadores, enfraquecendo os adversários e fortalecendo os aliados. Por não possuírem nenhum atributo próprio elevado, costumam sempre jogar ao lado de outros jogadores. Podem ser especialistas em melhorar os atributos de seus aliados (encantadores) ou em atrapalhar o avanço e as habilidades dos adversários (disruptores).

6. Tanques: Estes campeões possuem grande resistência contra os danos adversários, enquanto possuem baixo poder de ataque e baixa mobilidade, servindo como peças de controle do avanço adversário. Podem ser especialistas em bloquear o avanço inimigo (vanguarda) ou em proteger e receber dano no lugar de seus aliados (protetores). 
7. Únicos: São campeões que não se encaixam claramente em nenhuma das funções descritas acima, possuindo um conjunto de habilidades inusitado e servindo como um "coringa" dentro de um time.

Alguns campeões podem ser classificados como híbridos, pois seu conjunto de habilidades pode ser utilizado para atender às exigências de duas funções ao mesmo tempo, cabendo ao jogador escolher como e quando utilizá-las; por exemplo, as personagens Karma (Suporte encantador / mago de batalha), Graves (Atirador / Lutador duelista) e Nidalee (Retalhador assassino / Mago de artilharia) são exemplos de campeões híbridos.

Para além das funções dos campeões, há uma considerável importância a respeito da posição dos jogadores dentro do espaço de jogo. No LOL, o cenário de Summoners Rift é um mapa tridimensional, porém nem todos os trechos deste mapa são acessíveis aos jogadores. Espen Aarseth, em seu artigo de 2001, intitulado "Allegories of Space: The question of spaciality in Computer Games” argumenta que a representação espacial em jogos digitais é “...uma operação redutiva que leva a uma representação de espaço que não é em si espacial, mas simbólica e baseada em regras" (AARSETH, 2001, p.163 - tradução nossa), e um dos exemplos utilizados pelo autor quando explica este conceito é o do jogo de exploração Myst (1993), cuja tratativa espacial é descrita por Aarseth como “...uma variação de um jogo em ambientes internos: descontínuo, labiríntico, cheio de obstáculos construídos” (2001, p. 164 - tradução nossa).

O termo "ambientes internos" (indoor game) é parte de uma oposição proposta por Aarseth no decorrer do artigo, entre os jogos em ambientes internos (indoor games) e os jogos em ambientes externos (outdoor games); o primeiro termo se refere aos tipos de jogos que são como se fossem labirintos, “...uma topologia constritiva de nós e conexões entre estes, que interfere com o movimento irrestrito.” (Aarseth, 2001, p. 161 - tradução nossa), jogos como Wolfstein 3D (1992) e DOOM (1993) são exemplos da categoria de jogos de ambiente interno. Já os jogos de ambiente externo são os jogos onde, apesar de haver um limite espacial para onde o jogador pode ir (o tamanho do mapa), a movimentação deste não possui limitações definidas. Este tipo de tratativa do espaço está presente em jogos como Age of Empires II (1999) Grant Theft Auto: Vice City (2002) e The Legend of Zelda: Breath of the Wild (2017). Neste sentido, podemos afirmar que, apesar de um recobrimento figurativo de um jogo de ambiente externo, $L O L$ é na verdade um jogo mais próximo do modelo de ambientes internos, como apresentado na figura a seguir: 
Figura 4 - À esquerda, renderização do cenário de Summoners Rift. À direita, mapa simplificado dos caminhos existentes no jogo.
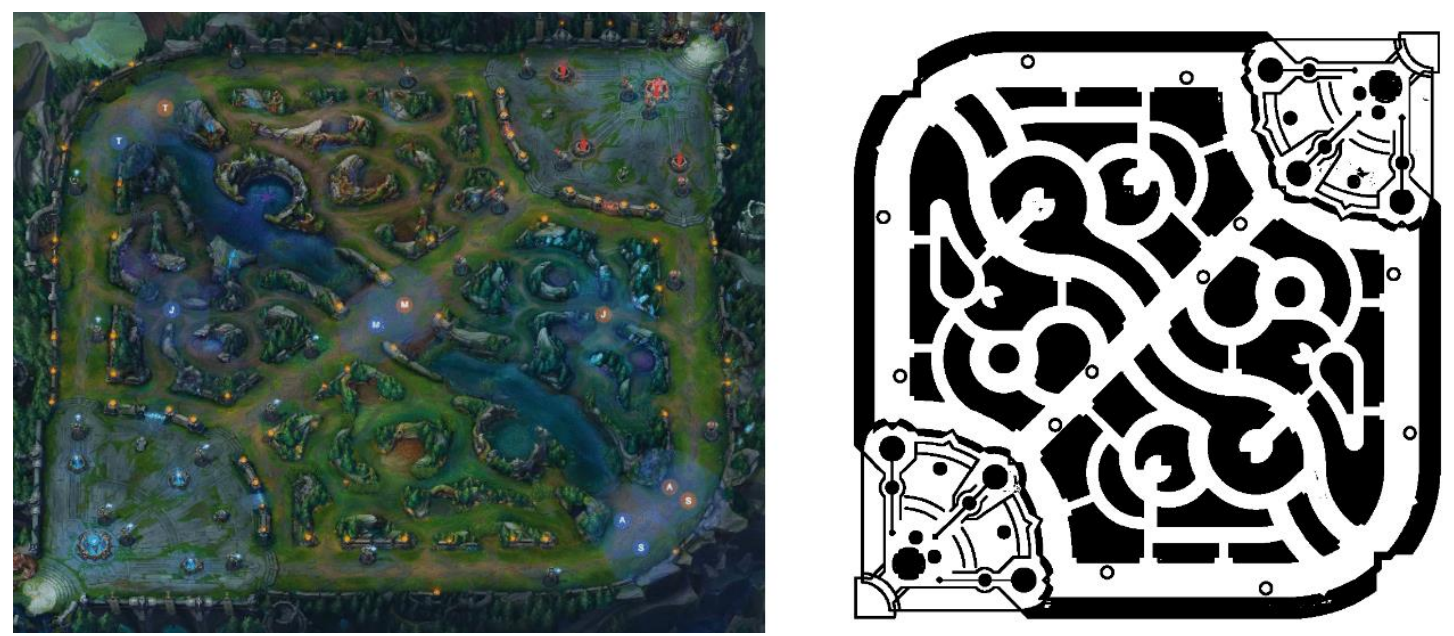

Fonte: imagem nossa, adaptada de Blizzard $(2020)^{18}$.

Possuindo limitadas opções sobre quais caminhos percorrer no mapa, as posições que os jogadores ocupam durante a partida são importantes, sendo chamadas de Rotas, influenciando na função de cada jogador durante a partida. As principais áreas presentes no mapa de Summoners Rift se dividem da seguinte forma:

Figura 5 - Divisão em cores dos setores de Summoners Rift.

18 Disponível em: <https://www.techtudo.com.br/noticias/2018/07/summoners-rift-conheca-o-mapa-de-league-oflegends-guialol.ghtml>. (Acesso em: 09 mar. 2021). 


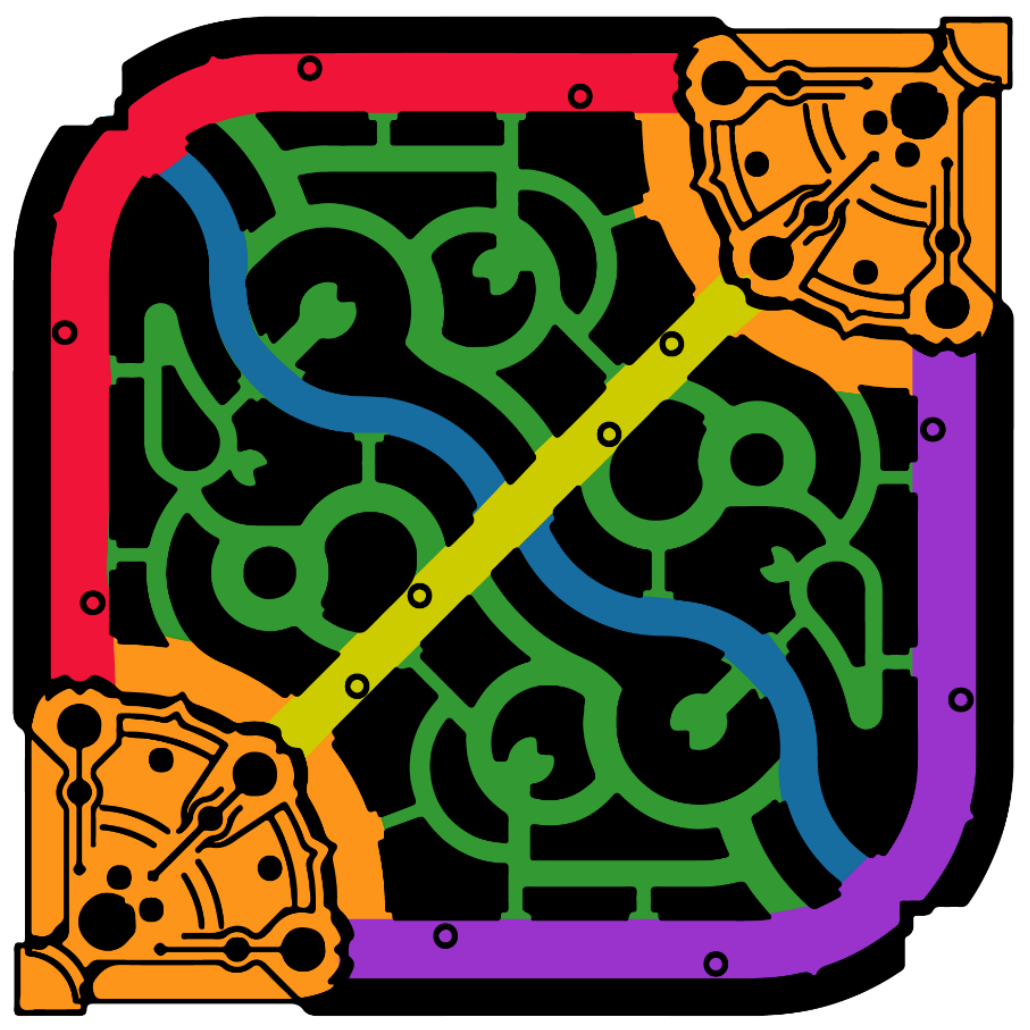

Fonte: imagem nossa, adaptada de Blizzard (2020). ${ }^{19}$

1. Nexus (Laranja): Localizados em cantos opostos do mapa, são os "Totens" de cada time; é o local onde os campeões renascem cada vez que são derrotados, onde os jogadores podem comprar novas habilidades, e o local que os jogadores devem defender dos campeões adversários.

2. Topo (Vermelho): Um dos principais caminhos para o "Totem" adversário, geralmente este caminho é ocupado por Campeões do tipo Tanque ou Lutadores, onde estes devem jogar sozinhos, abater as tropas que circulam no caminho e ajudar os aliados a abater as criaturas na parte superior da selva.

19 Disponível em: <https://www.techtudo.com.br/noticias/2018/07/summoners-rift-conheca-o-mapa-de-league-oflegends-guialol.ghtml>. (Acesso em: 09 mar. 2021). 
3. Meio (Amarelo): Outro dos principais caminhos para o "Totem" adversário, geralmente este caminho é ocupado por campeões do tipo Mago ou Retalhador. A função destes campeões é infligir a maior quantidade de dano ao adversário bem como controlar a circulação pelo rio e abater as criaturas próximas.

4. Bot Lane (Roxo): O terceiro caminho principal até o "Totem" adversário, geralmente é ocupado por dois campeões, um atirador e um suporte. $\mathrm{O}$ atirador deve se ocupar em infligir o máximo de dano no adversário, enquanto o suporte deve prestar assistência defensiva e ofensiva ao atirador, bem como auxiliar o campeão que estiver na selva.

5. Rio (Azul): É o rio que corta toda a extensão de Summoners Rift, não é fixamente ocupado por nenhum campeão, mas é utilizado por todos como a forma de deslocamento mais rápido entre as três linhas principais, sem a necessidade de se embrenhar pela selva.

6. Selva (Verde): Todo o espaço de Summoners Rift que não se encaixa nas opções citadas anteriormente, é um espaço labiríntico onde estão todas as criaturas do jogo. Geralmente ocupado por um campeão do tipo Lutador, Tanque ou Retalhador, que tem como principal função enfrentar as criaturas e promover ataques ou apoios nas linhas de topo e meio.

No próximo capítulo, as variantes de $L O L$ serão analisadas mais a fundo. Primeiro, é necessário apresentar também o segundo jogo presente no corpus de pesquisa.

\subsubsection{Overwatch}

Desenvolvido pela empresa estadunidense Blizzard Entertainment, lançado em 2016; é um jogo pago. Este jogo multijogador também possui grande popularidade, tendo campeonatos regionais na Austrália, Europa, América do Sul, China, Coréia do Sul, Estados Unidos, entre outros. 
O campeonato mundial de 2019 teve cerca de 1.12 milhões de espectadore ${ }^{20}$. Ao contrário de $L O L$, o jogo Overwatch não possui um mapa único ou um modo de jogo que seja suficientemente homogêneo dentro da comunidade. Os principais modos de jogo de Overwatch disponíveis são:

1. Assalto (Conquista de Base): Neste jogo, existem dois times de 6 jogadores cada, bem como dois "pontos de captura", que são círculos espalhados pelo mapa. Neste modo de jogo, cabe a um dos times o papel de defender os pontos de captura, enquanto ao outro time cabe o papel de controlar tais pontos. Para que a conquista se efetue, os jogadores do time atacante devem permanecer, com ao menos um jogador, dentro dos pontos de captura da arena durante um determinado período, sem que haja unidades inimigas dentro do mesmo espaço. Quanto mais jogadores do time atacante estiverem dentro do ponto de captura, mais rápida a conquista do ponto ocorrerá. Caso o time atacante não consiga conquistar todas as bases necessárias para sua vitória dentro do tempo estipulado, o time defensor será o campeão.

2. Controle (Rei do Monte): Neste modo de jogo, novamente com 6 jogadores em cada um dos times, o objetivo de ambos os times é conquistar um ponto de controle neutro, dentro da arena. O primeiro time que conseguir se manter tempo o suficiente dentro do ponto de controle irá dominá-lo, e a partir deste ponto um contador será ativado. Depois do ponto de controle estar conquistado, o time sem o domínio do ponto de controle (que chamaremos de A) deve tentar roubá-lo do time que o possui (que o chamaremos de B). Caso o time A consiga roubar o ponto de controle, o contador do time B para de acrescer, e é o contador do time A que começa a acrescer, invertendo os papéis dos dois times. O time que conseguir fazer com que seu contador seja completado primeiro, mantendo o domínio cumulativo do ponto de controle por mais tempo, vence a partida.

${ }^{20}$ STEDMAN, Alex. Overwatch League's Grand Finals Grows 16\% in Average Viewers From Last Year. Variety. 03 oct. 2019. Disponível em: <https://variety.com/2019/digital/news/Overwatch-league-grand-finals-viewership2019-1203357584/> Acesso em: 24 Mar. 2020. 
3. Escolta (Caravana): Neste modo de jogo, novamente com dois times de 6 jogadores, um dos times fica encarregado de escoltar um carro (com recobrimentos figurativos diversos, dependendo do mapa em que o jogo ocorre) que segue num trilho fixo através do mapa, enquanto o outro time deve impedir que o carro chegue ao seu destino. Quanto mais membros do time da caravana estiverem próximos do carro, mais rápido este andará. Já quando os inimigos ao redor da caravana forem em maior número, ela não se moverá. Caso o time da caravana consiga mover o carro até seu ponto de destino antes do fim do cronômetro, será o vitorioso; caso contrário, o time defensor será o vencedor.

4. Deathmatch (Combate por pontos): Neste modo de jogo, que pode ser jogado em dois times de 4 jogadores ou com 8 jogadores jogando cada um por si, o objetivo dos jogadores/times é adquirir uma determinada quantidade de pontos antes de seus adversários. Para adquirir pontos, os jogadores/times devem eliminar seus adversários em combate. O jogador/time que atingir a quantidade de pontos determinado primeiro, ou o jogador/time que tiver chegado mais perto desta meta ao fim do tempo da partida, é o vencedor.

5. Eliminação (Morte Súbita): Dois times de 1, 3 ou 6 pessoas, se enfrentam dentro do mapa, numa batalha onde, ao contrário de todos os modos descritos acima, não há o respawn, ou seja, quando um jogador é eliminado, ele não retorna para a partida novamente. O primeiro time/jogador a conseguir eliminar todos os seus adversários vence.

6. Híbrido: Há ainda modos de jogo híbridos que misturam dois ou mais dentre os modos de jogo descritos acima. Porém neste caso as regras apenas se acumulam, não havendo a necessidade de análise particular destes. 
Quanto às personagens que os jogadores podem escolher, Overwatch possui atualmente $32^{21}$ personagens disponíveis. Estes personagens são chamados de Heróis e, tal qual como foi descrito em $L O L$, cada herói possui um kit de Habilidades únicas, porém ao contrário do jogo analisado anteriormente, os heróis de Overwatch não possuem um número igual de habilidades, e alguns ainda podem possuir variações como habilidades passivas (habilidades que não precisam ser "ativadas" pelo jogador, pois funcionam automaticamente na programação do jogo). A única consistência no tangente às habilidades dos heróis é o fato de todos possuírem uma habilidade chamada Ultimate, considerado um movimento especial de alto poder e de alto custo (seja energético ou pelo tempo gasto entre cada uso) para o jogador. Outra variante importante entre cada herói de Overwatch é que as armas utilizadas pelos jogadores possuem comportamentos diferentes, bem como efeitos especiais ou efeitos secundários ao serem utilizadas.

Assim como LOL, os heróis de Overwatch são divididos de acordo com o perfil de uso para o qual eles são imaginados; estes perfis são chamados de Classes. Em Overwatch, existem quatro tipos de classes nos quais os heróis se encaixam:

1. Ofensivo: São heróis com alta mobilidade e grande capacidade de infligir dano nos adversários, porém são heróis com poucos pontos de vida para a quantidade de dano à qual se expõe. A principal função dos heróis ofensivos é eliminar o máximo de jogadores adversários. Os heróis ofensivos se dividem ainda em um estilo de Soldado (mais robusto, adequado ao combate direto) ou de um Assassino (mais rápido e frágil, para ataques-surpresa).

2. Defensivo: Os heróis defensivos possuem grande capacidade de infligir dano, maior ainda que o dos heróis ofensivos. Porém, os heróis defensivos possuem pouca mobilidade, e parte das suas habilidades são voltadas a defesa de um espaço ou a atrapalhar os jogadores adversários, muito mais do que apenas aplicar dano. A função principal destes heróis é conter o avanço dos adversários.

\footnotetext{
${ }^{21}$ Assim como no caso de $L O L$, os desenvolvedores de Overwatch adicionam novos campeões às opções do jogador periodicamente. Porém no caso de Overwatch, a média de personagens novos adicionados por ano é menor, não ultrapassado 2 por ano.
} 
3. Tanque: Os heróis do tipo tanque, similar à sua contraparte em $L O L$, são heróis que tem como principal função a de levar o máximo de dano em nome do resto do time, pois possuem uma grande quantidade de pontos de vida, baixo poder ofensivo, baixa mobilidade e habilidades que ajudam a proteger os colegas de time.

4. Suporte: Os heróis de suporte são heróis que tem como principal função a de curar seus aliados e usar suas habilidades para atrapalhar a organização e as habilidades dos adversários. Não possuem um poder ofensivo extraordinário nem muitos pontos de vida, funcionando melhor sempre apoiando outros tipos de herói no avanço ou defesa de um objetivo.

Quanto aos mapas onde o jogo pode ocorrer (ao contrário de $L O L$, Overwatch possui diversos mapas, e nenhum deles goza de absoluta preferência dos jogadores, como é o caso de Summoners Rift), os cenários de Overwatch se mostram próximos do jogo de ambiente externo (outdoor games), dentro dos parâmetros de Aarseth que analisamos anteriormente (p. 16). Os mapas de Overwatch são arenas abertas, onde os personagens podem circular pela grande maioria dos espaços visíveis dentro do jogo, podendo inclusive realizar pequenos voos pelo espaço aéreo do jogo, como podemos ver na figura abaixo:

Figura 6 - Visualização de uma partida em Overwatch. 


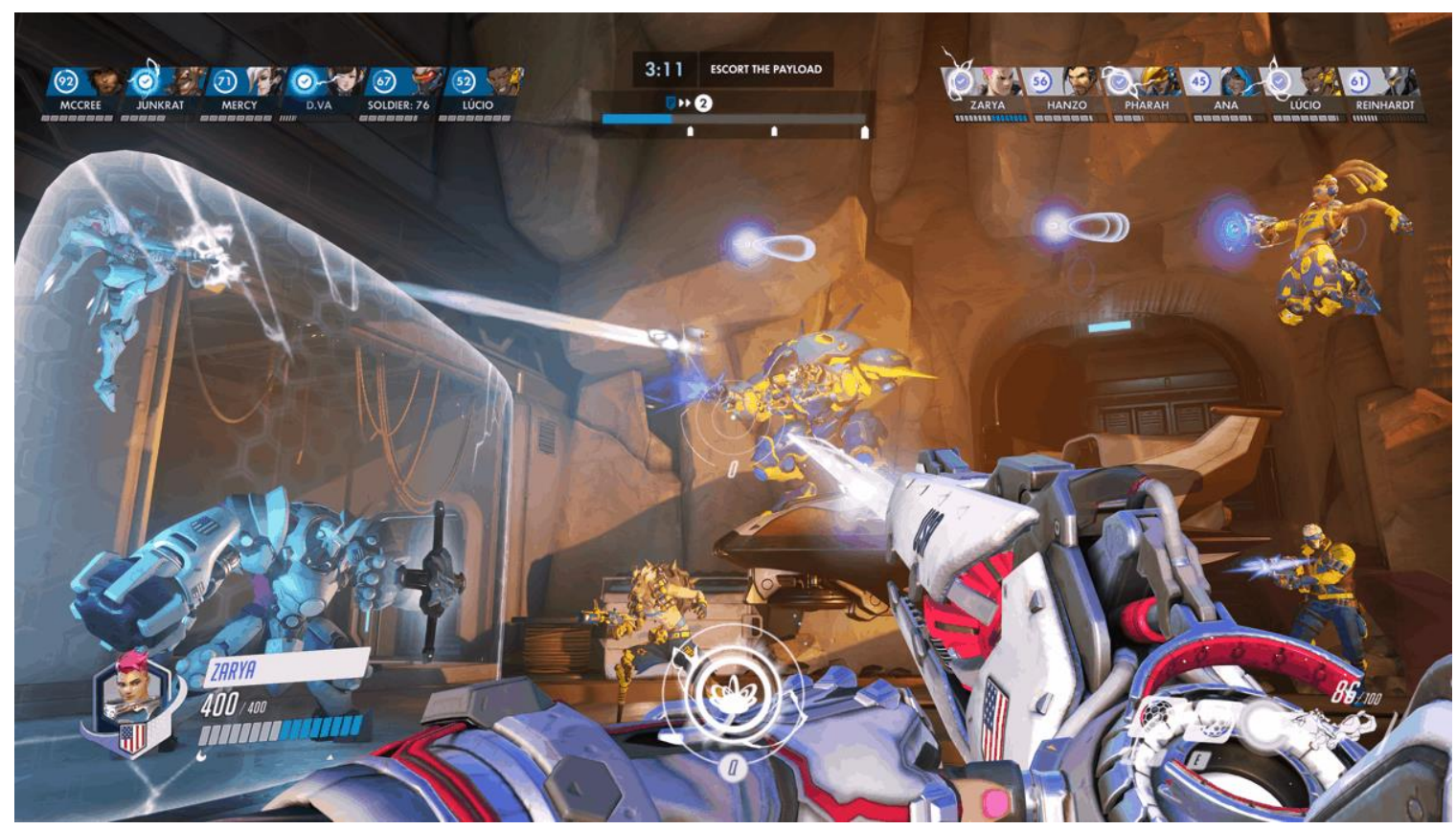

Fonte: imagem nossa, adaptada de Blizzard $(2020)^{22}$

Por fim, uma última característica preliminar importante de ser levantada diz respeito às diferenças no uso de câmeras entre $L O L$ e Overwatch: o primeiro é um jogo em terceira pessoa, enquanto o último é um jogo em primeira pessoa. Cardozo Angelo (2015) descreve a diferenciação entre estes dois tipos de câmera, do ponto de vista semiótico, como:

Os jogos em primeira pessoa - referentes ao ponto de vista do player character representado visualmente - refletem um processo de Debreagem enunciativa de pessoa. A estratégia é comum em jogos de tiro, mas dificilmente será empregada em jogos de interpretação de papéis, conhecidos como RPG. Nos jogos RPG [...] é saliente a importância conferida à densidade sêmica dos personagens - ou seja, ao alto grau de detalhe conferido pelo recobrimento figurativo - e à escolha de atributos físicos, de armas e de vestuário, bem como à visualização de toda a cena de confronto. (ANGELO, 2015, p. 36).

Exemplos da utilização das câmeras nos casos de $L O L$ e Overwatch podem ser vistos na imagem a seguir:

Figura 7 - Comparação das telas de jogo de Overwatch (esquerda) e League of Legends (direita).

${ }^{22}$ Disponível em: <https://daverupert.com/2017/11/team-incentives-in-overwatch/>. Acesso em: 09 mar. 2021. 


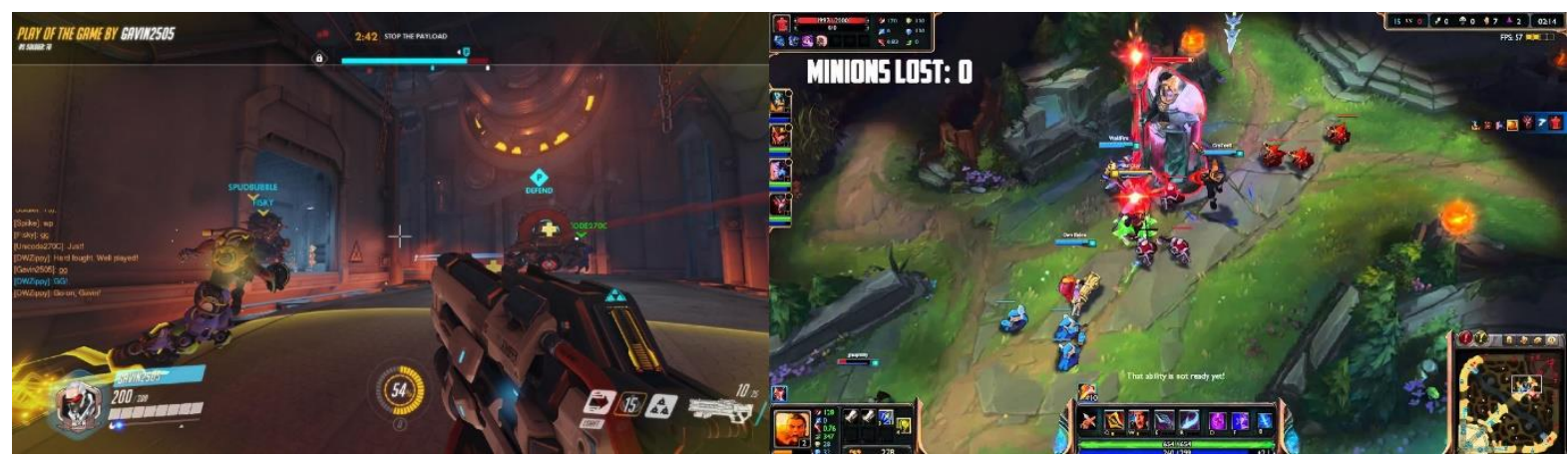

Fonte: Youtube $(2020)^{23}$.

Enquanto ambos os jogos analisados nesta pesquisa não são de gêneros tão divergentes quanto os jogos utilizados na dissertação de Cardozo Angelo, o fato de $L O L$ ser um jogo de terceira pessoa, enquanto Overwatch é um jogo de primeira pessoa, gera reflexos dentro da própria dinâmica do jogo. Em $L O L$, as partidas são mais longas, chegando a ter duração média de 30 minutos, onde a posição coletiva de cada membro do grupo é de grande importância para a partida, e os jogadores possuem progressão de suas habilidades, bem como podem comprar itens em seu próprio "totem" para melhorar seu desempenho nas diversas etapas que cada partida possui. Para este tipo de administração, uma câmera em $3^{\mathrm{a}}$ pessoa que diminui a intensidade dos acontecimentos e permite um campo de presença maior, para a devida apreensão de todos os diversos elementos interativos no cenário é mais adequada, enquanto uma câmera em $1^{\mathrm{a}}$ pessoa é mais coerente para Overwatch, que possui partidas que duram entre 5 e 10 minutos, e onde há um menor campo de presença devido à intensidade da partida, além de poucos elementos interativos no cenário que não sejam os próprios jogadores ou os elementos criados por suas habilidades, como barreiras ou estruturas de defesa. Em ambos os casos, a câmera escolhida ajuda a definir a cadência do jogo, sendo Overwatch um jogo mais intenso e frenético, enquanto $L O L$ é um jogo mais estratégico e segmentado em etapas.

${ }^{23}$ Disponível em <https://www.youtube.com/watch?v=YBbWxfEbZFc>. (Acesso em: 09 mar 2021). e <https:// www.youtube.com/watch?v=dziStDTsFDw>. Acesso em: 09 mar 2021. 
Após esta análise preliminar dos jogos do corpus desta pesquisa, o próximo capítulo será reservado à análise de $L O L$ e Overwatch de acordo com os parâmetros do modelo de Cardozo Angelo.

\subsection{Uma narrativa em múltiplos espaços}

Quando se observa a narrativa que o jogo conta aos jogadores do ponto de vista do percurso gerativo de sentido desenvolvido por Greimas, há algumas características deste tipo de objeto - um MOBA, no caso de $L O L$ e um jogo de tiro em primeira pessoa, no caso de Overwatch, ambos jogos multijogador - que merecem ser analisadas com mais detalhe.

Overwatch e $L O L$ são jogos concebidos para serem jogados com outros jogadores, em partidas curtas e repetidas de enfrentamento. Tanto em Overwatch quanto em $L O L$, para cada partida, os jogadores devem escolher uma personagem, e ambos os sites de acesso ao jogo mantém uma relação atualizada das personagens disponíveis, suas características e a narrativa ficcional da personagem dentro do universo do jogo 2425 .

Tanto $L O L$ quanto Overwatch são projetos transmídia. Este termo é central para o trabalho de Henry Jenkins, pesquisador da área de tecnologia e autor do livro Cultura da Convergência, livro onde é apresentada uma definição de um projeto transmídia:

Uma história transmídia desenrola-se através de múltiplas plataformas de mídia, com cada novo texto contribuindo de maneira distintiva e valiosa para o todo. $\mathrm{Na}$ forma ideal de narrativa transmídia, cada meio faz o que faz de melhor - a fim de que uma história possa ser introduzida num filme, ser expandida pela televisão, romances e quadrinhos; seu universo possa ser explorado em games ou experimentado como atração de parque de diversões. Cada acesso à franquia deve ser autônomo, para que não seja necessário ver o filme para gostar do game, e vice-versa. Cada produto determinado é um ponto de acesso à franquia como um

\footnotetext{
${ }^{24}$ BLIZZARD. Precisa de um herói? Overwatch. Disponível em: 〈https://playOverwatch.com/pt-br/heroes >. Acesso em: 14 fev. 2021.

25 RIOT GAMES. Campeões. League of Legends. Disponível em: <https://universe.leagueoflegends.com/ pt_BR/champions/>. Acesso em: 14 fev. 2021.
} 
todo. A compreensão obtida por meio de diversas mídias sustenta uma profundidade de experiência que motiva mais consumo (JENKINS, 2009, p. 138)

No caso de $L O L$ e Overwatch, eles não são formas ideais de narrativa transmídia: sendo o jogo de videogame o produto principal de ambos os universos narrativos, eles acabam sendo o “centro narrativo", relegando às demais mídias, como os quadrinhos ou clipes de vídeo a função de acrescentar informações extras. Porém, como as informações das demais mídias não se encontram obrigatoriamente no jogo de videogame, Overwatch e $L O L$ ainda se adequam à categoria de projeto transmídia.

Ao observarmos o perfil dos personagens dentro do site oficial do jogo, é perceptível a natureza central deste meio na estrutura narrativa do universo ficcional:

Figura 8 - Exemplo do perfil de um campeão em League of Legends.

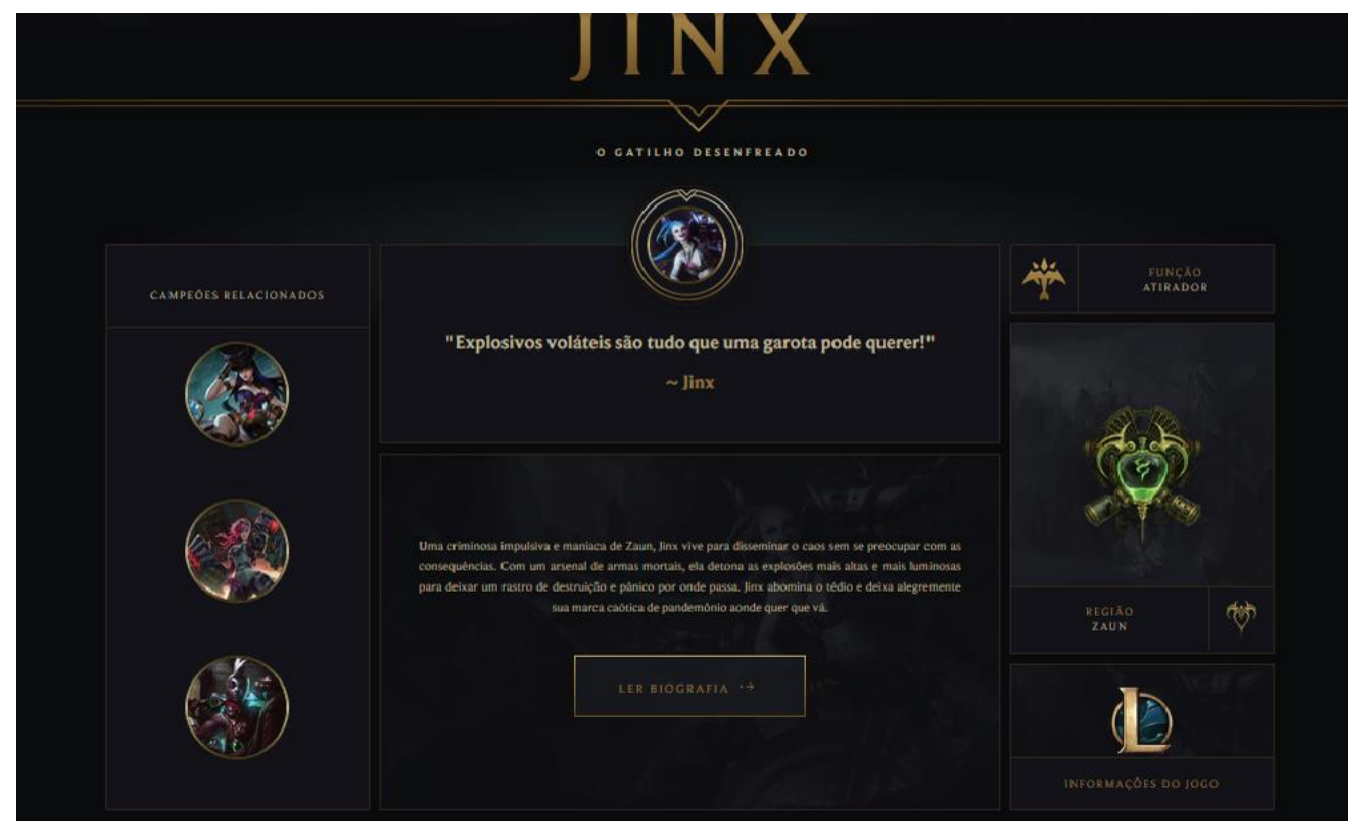

Fonte: Riot (2020). ${ }^{26}$

A figura acima apresenta o perfil de um dos campeões disponíveis no $L O L$, onde diversos links levam a outras páginas ou até mesmo outros sites, que contém vídeos ou quadrinhos. A

\footnotetext{
${ }^{26}$ Disponível em <https://universe.leagueoflegends.com/pt_BR/champion/jinx/>. Acesso em 09 mar. 2021.
} 
organização desta narrativa transmídia é facilitada por um método de organização textual estudado por Espen Aarseth em seu livro Cybertext: Perspective on erodic literature, e descrito como o cybertexto. Para o autor, o cybertexto é uma perspectiva formal sobre como encarar o texto (tal forma existindo já antes da era digital, mas encontrando nesta sua maior disseminação, graças à ferramenta do Hiperlink). Um modo de leitura que

deve conter algum tipo de loop de feedback informacional. De certa forma, isto se se mostra verdadeiro para qualquer situação textual, contanto que o "texto" seja algo mais do que apenas marcas sobre uma superfície. Um leitor lê uma linha de palavras, e dependendo das ações subsequentes do leitor, o significado destas palavras pode mudar. (AARSETH, 1997, p. 19 - tradução nossa)

Este conceito será retomado no decorrer desta pesquisa. Por enquanto, basta a afirmação de que a dinâmica do cybertexto é largamente utilizada para a construção narrativa das personagens de $L O L$ e Overwatch, onde todas as informações narrativas da personagem são apresentadas na forma de hiperlinks para outras páginas ou até mesmo outros sites.

É importante destacar ainda a observação de Antônio Carlos Xavier (2009) quando este diferencia que o hipertexto é também uma questão de concepção, ao afirmar que:

A inovação trazida pelo hipertexto está em transformar a deslinearização, a ausência de um foco dominante de leitura, em princípio básico de sua construção. A deslinearidade está prevista já em sua concepção. Refiro-me aos textos originalmente construídos com as propriedades do hipertexto e não àqueles apenas copiados na rede, posto que todo texto impresso pode ser um hipertexto, mas nem todo hipertexto pode ser um texto impresso (XAVIER, 2009, p. 2013)

Os textos presentes nos jogos analisados neste momento e nos fóruns a serem analisados nos próximos capítulos são hipertextos, no sentido de serem concebidos para o uso no ambiente digital e para a leitura ergódica e descentralizada.

\section{5 percurso narrativo greimasiano e o corpus analisado}

Após a visita dos principais hiperlinks que apresentam a construção narrativa das histórias das personagens de ambos os jogos, é perceptível que os dois jogos possuem uma estrutura muito similar aos modelos de contos de fadas estudados na tradição folclorista de Vladimir Propp (2010), 
pois são fruto direto das constrições de estudiosos como C.G. Jung, Joseph Campbell e Christopher Vogler, que possuem uma metodologia similar à de Propp ${ }^{27}$. Tal construção torna a estrutura das histórias de $L O L$ e de Overwatch mais simples de serem analisadas dentro do modelo greimasiano, especificamente no que tange ao nível narrativo, fortemente baseado nos estudos Proppianos. O gráfico a seguir foi construído a partir de anotações em aulas ministradas por Waldir Beividas durante o ano de 2019:

Figura 9 - Percurso narrativo.

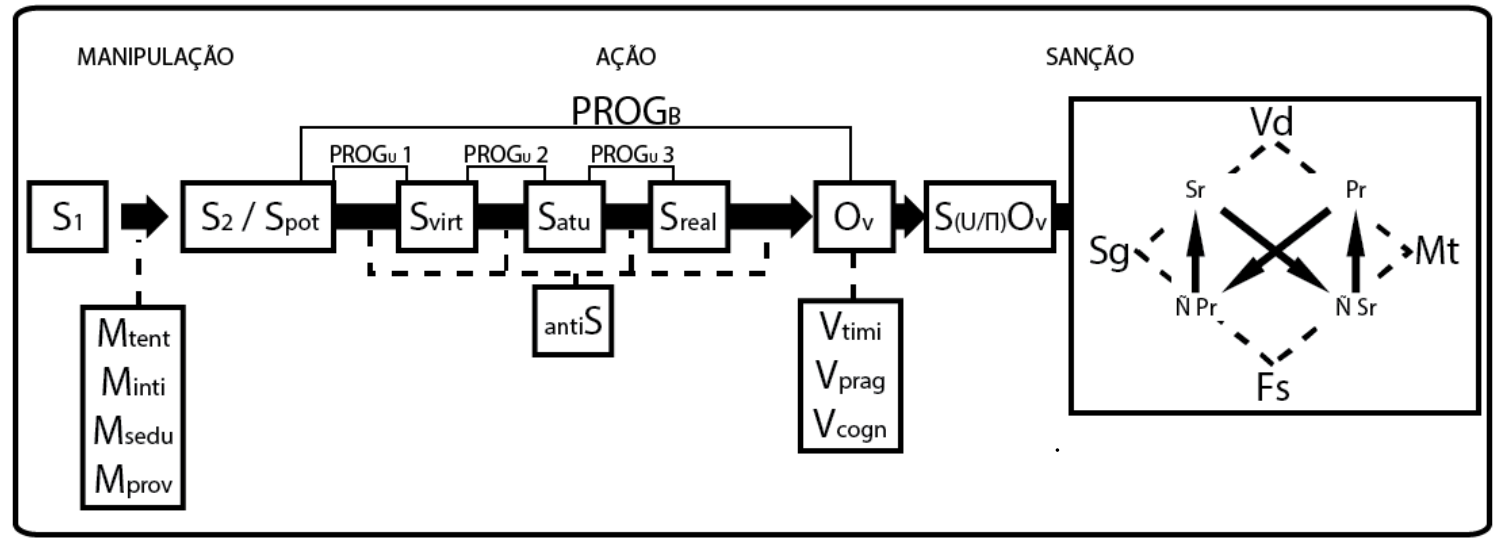

Fonte: imagem nossa, adaptada de BEIVIDAS (2019).

Este modelo sintetizado do percurso narrativo será utilizado nesta pesquisa para analisar a construção das histórias das personagens de Overwatch e $L O L$.

A primeira etapa é a fase da manipulação, onde a personagem do herói $\left(\mathrm{S}_{2}\right)$, que nesta etapa consiste em um actante que a semiótica chama de destinatário, é manipulada por um destinador $\left(\mathrm{S}_{1}\right)$, um actante que convence o destinatário a realizar a busca pelo seu objeto de valor $\left(\mathrm{O}_{\mathrm{V}}\right)$. Entre

\footnotetext{
${ }^{27}$ Aqui é referida uma linha de pesquisa sobre mitologia, iniciada por Henry James Fraser no começo do século XX, e seguida por C.G. Jung, Joseph Campbell, Christopher Vogler e Maureen Murdoch. Tal linha de pesquisa faz uma abordagem de caráter pandeterminista do mito - termo cunhado por Tzvetan Todorov (2017) nos anos 70, para definir, na literatura fantástica, a abordagem de um enredo onde "existem relações em todos os níveis, entre todos os elementos do mundo. Este mundo torna-se altamente significante" (p. 120). Tal abordagem foi amplamente utilizada como modelo narrativo por roteiristas de cinema, e num segundo momento, por game designers. Dado à densidade que pode atingir o estudo de tal corrente pandeterminista dos estudos do mito, ela não será abordada em profundidade nesta pesquisa. Basta observar que, enquanto a linha campbelliana via o mito pelo viés pandeterminista, a linha proppiana se prova mais cautelosa: "Se todos os contos de magia são tão semelhantes quanto à forma - isso significa, por acaso, que todos eles provêm da mesma fonte? (...) devemos porém, mais uma vez, ser muito cautelosos a este respeito. Se os limites do conto se explicassem pelos limites da capacidade imaginativa do homem, não teríamos outros contos a não ser os inscritos na categoria estudada, quando na realidade existem milhares de outros que nada têm a ver com os contos de magia. Finalmente, a fonte única pode ser encontrada na realidade cotidiana." (PROPP, 2010, p. 105).
} 
o destinador e o destinatário, é acordado um contrato fiduciário, onde o destinatário busca o objeto de valor, e em troca recebe uma sanção positiva por parte do destinador.

Para convencer o destinatário a ir em busca do objeto de valor, o destinador pode usar métodos manipulativos, de acordo com os saberes ou poderes que ele possui ${ }^{28}$, sendo estes métodos os seguintes:

1. tentação $\left(\mathrm{M}_{\mathrm{tent}}\right)$, oferecendo algo que o destinatário queira em troca da realização do contrato;

2. intimidação $\left(\mathrm{M}_{\mathrm{inti}}\right)$, ameaçando o destinatário caso não realize o contrato;

3. sedução $\left(\mathrm{M}_{\mathrm{sedu}}\right)$, onde o destinador faz um juízo positivo do destinatário; induzindoo a cumprir o contrato para comprovar tal juízo;

4. provocação $\left(\mathrm{M}_{\text {prov }}\right)$, onde o destinador faz um juízo negativo do destinatário, e este deve cumprir o contrato para prová-lo errado.

Note-se que a manipulação do destinador pode envolver mais de um tipo de manipulação entre as citadas cumulativamente.

Encerrada a etapa de manipulação, a narrativa entra na etapa da ação, onde o destinatário se torna um sujeito potencial $\left(\mathrm{S}_{\mathrm{pot}}\right)$, que é o sujeito que está em uma relação jectal ${ }^{29}$ com o objeto de valor $\left(\mathrm{O}_{\mathrm{v}}\right)$, portanto em sua busca. Para entrar em conjunção com o objeto de valor e superar a jornada em busca deste, o sujeito precisa possuir as competências e capacidades para tal. $\mathrm{Na}$ semiótica estas competências são chamadas de modalidades.

\footnotetext{
${ }^{28}$ Ou que o destinatário acha que o destinador possui. Para convencer o destinatário o destinador não precisa necessariamente ser um ser poderoso, ele apenas precisa que o destinatário creia que o destinador é um ser que possui o saber/poder necessários para manipulá-lo a ir em busca do objeto.

${ }^{29}$ Jectal é o termo utilizado por Luiz Tatit para descrever a relação simbiótica entre o sujeito e o objeto de valor, onde ao estar separado do objeto de valor, o sujeito fica impelido a buscá-lo, pois a existência semiótica deste depende da existência e desejo de junção com o objeto de valor. Descrito em detalhes no glossário no fim da dissertação.
} 
Para adquirir tais modalidades, o sujeito precisa realizar programas, que são como "etapas" na busca pelo objeto. Um exemplo que podemos retirar dos contos-de-fada clássico, é o exemplo do cavaleiro que vai enfrentar um dragão, porém precisa primeiro pegar uma espada mágica que é a única capaz de matar tal dragão. Matar o dragão é o que a semiótica chama de Programa de Base $\left(\mathrm{PROG}_{\mathrm{B}}\right)$, o objetivo final da jornada da personagem, a junção com o objeto de valor, já os Programas de Uso (PROGU $1 / \mathrm{PROG}_{\mathrm{U}}$ 2/PROGU 3 ) são as etapas modalizadoras necessárias para a realização do programa de base, como no caso de nosso exemplo anterior, conseguir a espada mágica.

O sujeito potencial pode se tornar um sujeito virtualizado ( $\mathrm{S}_{\mathrm{VIRT}}$ ) quando adquirir as modalidades do Dever e/ou Querer entrar em conjunção com o objeto. O sujeito virtualizado pode se tornar um sujeito atualizado $\left(\mathrm{S}_{\mathrm{ATU}}\right)$ quando adquirir as modalidades do Saber e/ou Poder entrar em conjunção com o objeto. Somente após adquirir estas modalidades é que o Sujeito se torna um sujeito realizado $\left(\mathrm{S}_{\mathrm{REAL}}\right)$, que é o sujeito que consegue entrar em conjunção com o objeto, encerrando a etapa da ação da narrativa.

Durante toda a etapa da ação, a busca do actante sujeito pelos programas de uso e pelo programa de base pode sofrer impedimentos. Estes impedimentos, no jargão semiótico, são atribuídos ao actante Anti-Sujeito (ANTIS), que é qualquer elemento na narrativa que tenha como principal função impedir a conjunção do sujeito com o seu objeto de valor.

Após o fim da etapa da ação, tem início a última etapa, que é a etapa da sanção. Esta etapa será analisada em maior detalhe, pois possui grande relevância para esta pesquisa.

$\mathrm{Na}$ etapa da sanção, o sujeito já está em conjunção (ח) ou disjunção (U) com o objeto (o que, no gráfico acima, é descrito na expressão $\left.\mathrm{S}_{(\mathrm{U} / \cap)} \mathrm{O}_{\mathrm{V}}\right)$, e o percurso da ação será sancionado ${ }^{30}$. A sanção é a principal consequência do fazer performativo do sujeito, que por sua vez é decorrente da manipulação.

\footnotetext{
${ }^{30}$ Geralmente a sanção é feita pela mesma personagem que foi o destinador na etapa da manipulação, porém pode haver exceções.
} 
$\mathrm{Na}$ prática do "percurso narrativo da sanção ou percurso do destinador-julgador, o destinador interpreta as ações do destinatário-sujeito, julga-o, segundo certos valores, e dá-lhe a retribuição devida, sob a forma de punições ou de recompensas.” (BARROS, 2005, p. 85). De acordo com Greimas e Courtés, no Dicionário de Semiótica, a sanção no nível narrativo é uma sanção que "enquanto exercida pelo destinador final, pressupõe nele um absoluto de competência" (GREIMAS \& COURTÉS, 2008, p. 426). Portanto, o julgador que sanciona é alguém capacitado para sancionar.

José Luiz Fiorin, em seu Elementos da Análise do Discurso (2008), fala da etapa da sanção como a fase em que "ocorre a constatação de que a performance se realizou e, por conseguinte, o reconhecimento do sujeito que operou a transformação" (FIORIN, 2014, p. 31) e afirma ainda que:

A narrativa pode pôr em ação um jogo de máscaras: segredos que devem ser desvelados, mentiras que precisam ser reveladas etc. É na fase da sanção que ocorrem as descobertas e as revelações. É, neste ponto da narrativa, por exemplo, que os falsos heróis são desmascarados e os verdadeiros são reconhecidos (FIORIN, 2014, p. 31)

No nível narrativo, a sanção possui duas dimensões: a sanção pragmática e a sanção cognitiva. A sanção pragmática é, segundo o Dicionário de Semiótica, um juízo epistêmico, proferido pelo destinador-julgador, que diz respeito a recompensas figurativamente recobertas. Um exemplo, tirado das narrativas clássicas de contos de fadas, é o do rei (destinador) que envia um cavaleiro (sujeito) para matar o dragão que aterroriza o reino (programa de base), e promete a mão de sua filha (objeto de valor) em troca.

Quando o cavaleiro retorna ao reino após matar o dragão, ele recebe a recompensa pragmática, que é a mão da princesa em casamento. Caso se descubra que o cavaleiro mentiu a respeito da morte do dragão, ele recebe uma sanção pragmática negativa (punição), como a sua prisão ou execução.

Toda a etapa da sanção é oriunda das provas de reconhecimento do herói, presentes nas pesquisas do folclorista russo Vladimir Propp, cujo trabalho sobre os contos-de-fadas russos acabou por se tornar a base para a construção do nível narrativo greimasiano. 
Esta pesquisa pretende, porém, focar a análise sobre as sanções divergentes entre o esquema da imanência e o da manifestação: o segredo (ser/não-parecer) e a mentira (não-ser/parecer). Estas sanções tradicionalmente se apresentam nos contos de fada como estados intermediários antes de uma sanção final: o herói escondido (segredo) prova ser o matador do dragão ao trazer consigo uma marca ou troféu (verdade) enquanto um falso herói (mentira) falha em apresentar a mesma prova, sendo desmascarado (falsidade). No ambiente de fórum, que será analisado no decorrer deste texto, tais estágios intermediários de veridicção se mostrarão importantes a esta pesquisa.

\subsubsection{Exemplos de narrativas presentes no corpus}

Descrito o modelo de análise de narrativa aos quais nos referenciaremos nesta pesquisa, serão analisados brevemente as histórias de seis personagens escolhidos dentre o nosso corpus: três campeões de LOL (Caitlin, Shen e Katarina) e três heróis de Overwatch (Junkrat, Soldado 76 e Pharah). De forma resumida, as narrativas são as seguintes:

- $\quad$ Soldado 76: Nascido nos estados unidos, Jack Morrison fez parte de um programa militar estadunidense para a criação de super-soldados (programa de uso) para lutar numa guerra em que a humanidade enfrentou robôs rebeldes, chamados Omnicos. Seu desempenho acaba por chamar a atenção da Overwatch ${ }^{31}$ (destinador), que o incorpora à sua equipe de agentes. Após a vitória contra os robôs, a Overwatch se torna uma força de manutenção de paz, e Morrison se torna o diretor executivo da instituição (contrato). No decorrer dos anos, uma série de sabotagens e ataques promovidas por inimigos como a organização Talon e seu ex-colega Gabriel Reyes (anti-sujeitos), a Overwatch acaba sendo extinguida e Morrison é dado como morto. Cinco anos depois, Morrison, agora um justiceiro conhecido como "Soldado 76", rouba tecnologia de ponta (programa de uso) e promove uma guerrilha contra

\footnotetext{
${ }^{31}$ Quando o nome do jogo for utilizado nas descrições da biografia das personagens, Overwatch corresponde à agência especial que recruta heróis como uma espécie de "força de paz" no universo do jogo.
} 
empresas para desvendar a conspiração contra a Overwatch (objeto/programa de base).

- Pharah: Filha de Ana Amari (destinador), uma agente da Overwatch, Fareeha Amari cresceu cercada pelos amigos de sua mãe, os heróis da Overwatch, e sempre treinou rigorosamente, sonhando em se juntar aos heróis que eram sua mãe e os amigos dela, defendendo a justiça (contrato). Porém, após entrar no exército egípcio e se tornar apta como candidata (programa de uso), a Overwatch foi extinguida e sua mãe foi dada como desaparecida após uma missão (anti-sujeitos). Apesar do fim da Overwatch, Fareeha manteve seu objetivo de se tornar uma heroína que luta para proteger os outros (objeto/programa de base), e se filiou a uma empresa de segurança particular, que forneceu a Fareeha uma nova armadura de combate experimental (programa de uso) para combate.

- Junkrat: Durante a guerra com os robôs ômnicos, um ataque destes a um reator nuclear gerou uma grande explosão, destruindo grande parte dos recursos e habitantes do outback australiano. Jamison Fawkes e os demais sobreviventes formaram uma sociedade caótica, consequência dos danos físicos e psicológicos sofridos pela radiação (destinador). Fawkes se tornou um especialista em explosivos obcecado por destruição (objeto/programa de base), e acabou ganhando notoriedade quando descobriu formas poderosas de usar as carcaças dos robôs da região (programa de uso). Para promover seu estilo de vida caótico, bem como conseguir financiá-lo (contrato), Fawkes fugiu da cidade caótica, onde foi perseguido pela regente ditatorial (anti-sujeito) e começou uma turnê de roubos que colocou as autoridades em alerta (anti-sujeito).

- Caitlin: Filha de uma família rica e influente de inventores, Caitlin gastou grande parte de sua infância caçando com armas de alta qualidade (programa de uso), nos terrenos selvagens vizinhos da sua cidade Pitlover. Seus pais sempre lhe passaram uma bússola moral intensa (destinador), porém ela só compreendeu a necessidade de tal fibra moral quando seus pais foram sequestrados por inventores rivais, sendo obrigados a produzir para eles sob regime de trabalhos forçados, regime este do qual 
só foram libertados quando sua própria filha, que conseguiu aplicar na cidade suas habilidades de busca e caça (programa de uso) para encontrá-los e libertá-los. Após conhecer as entranhas corruptas de Pitlover (anti-sujeito), Caitlin decidiu usar seus recursos e habilidades como uma investigadora particular, para ajudar os injustiçados e caçar o autor do ataque a seus pais (programa de base). Após um caso particularmente difícil, Caitlin foi convidada pela polícia de Pitlover (destinador) para ser um dos xerifes da cidade, onde ela poderia ter os recursos para fazer seu trabalho (contrato).

- Shen: Filho de um clérigo da ordem Kinkou (destinador), desde a infância Shen esteve imerso na cultura e nos valores de justiça e de estoicidade pregados pela ordem (contrato), sendo um estudante e praticante exemplar (programa de uso). Junto com seu melhor amigo Zed, eles eram considerados prodígios dentro da ordem, e acabaram sendo encarregados por seu pai de caçar um assassino sádico chamado Jhin. Ao capturarem o assassino, Shen viu seu pai condená-lo a prisão ao invés da morte, e apesar de Shen e Zed questionarem o valor da punição, Shen condicionou-se a aceitála como de acordo aos valores da ordem de Kinkou, enquanto Zed se manteve ressentido. Posteriormente, durante uma guerra contra uma cidade vizinha chamada Noxus, a ordem Kinkou escolheu manter-se neutra e, ao voltar de uma missão em nome do templo, Shen descobriu um golpe feito por Zed contra o templo (anti-sujeito), onde seu pai e outros monges foram mortos como resultado. Assumindo a espada e o papel de seu pai (programa de uso) no que sobrou da ordem Kinkou, buscando novos aprendizes como Akali (destinatário), enquanto tenta reconstruir a ordem Kinkou (programa de base).

- Katarina: Filha de uma poderosa família da militarista cidade de Noxus, desde a infância foi ensinada de maneira impiedosa por seu pai, o general Du Cocteau (destinador), nas artes da espionagem e execução (programa de uso). Quando o general a levou para o campo de batalha pela primeira vez, lhe ordenou que fosse para trás das linhas inimigas e eliminasse um capitão plebeu (contrato). Katarina considerou que este alvo era indigno de todo o seu treino, e ao invés disso executou o general adversário. Seu alvo original, porém, liderou uma investida bem-sucedida 
contra as tropas de Noxus, e Katarina fugiu de vergonha e da ira de seu pai, que ordenou que ela fosse morta. Ela porém voltou ao acampamento inimigo e matou seu alvo original. Desde esse acidente, Katarina busca se redimir (objeto de valor) obedecendo perfeitamente as ordens de Noxus (programa de base).

Estas análises simplificadas não fazem jus ao nível de variedade e detalhe que as construções narrativas do universo ficcional do corpus possuem. Porém, são suficientes para apontar duas características gerais que unem todas as narrativas dos personagens que compõem o corpus: a primeira é a ausência da etapa da sanção dentro das narrativas do universo fantasioso, e a segunda é a existência de uma intrincada rede de interações entre os elementos do universo ficcional, que termina por fazer com que os recobrimentos figurativos tenham diferentes papéis actanciais, a depender de qual foco narrativo está sendo considerado.

\subsubsection{A ausência da sanção nas narrativas do universo ficcional}

O primeiro elemento particular da análise das narrativas dos dois jogos de nosso corpus, que merece ser analisado em detalhe, é o fato de que todas as histórias apresentadas pelo jogo não possuem a etapa da sanção. Todos os heróis e campeões apresentados são sujeitos já virtualizados e atualizados, portanto plenamente capazes de atingir seu objetivo no programa narrativo de junção com seu objeto de valor, mas tal junção nunca ocorre de fato.

Em um artigo intitulado Introduction to Game Time / Time to Play (2004), Jesper Juul estuda a construção temporal das narrativas em jogos. Em determinado ponto de sua exposição, o autor descreve o fluxo temporal-narrativo de um jogo tradicional, como uma "árvore gigantesca com numerosas bifurcações (os jogos salvos), numerosos pontos sem saída e apenas um caminho" (JUUL, 2004b, p. 138 - tradução nossa). Graficamente, tal sistema pode ser expresso da seguinte forma:

Figura 10 - Gráfico temporal-narrativo baseado no modelo de Juul. 


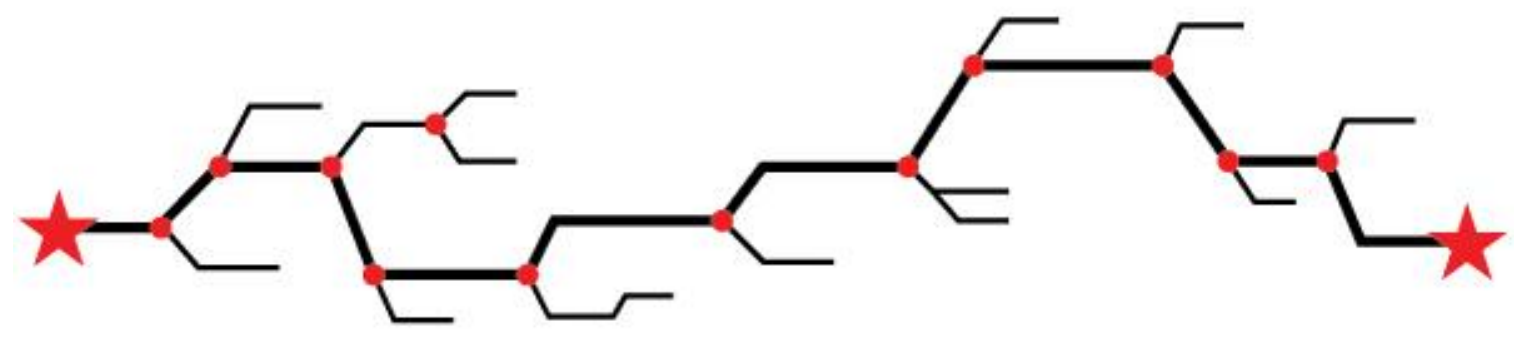

Fonte: imagem nossa.

A estrela vermelha à esquerda representa o início da narrativa-padrão em jogos, a estrela à direita representa o seu final. Cada ponto vermelho, de onde sai uma bifurcação da linha, é um ponto de salvamento do jogo, onde o jogador toma uma decisão. Os caminhos mais finos que se encerram logo depois das bifurcações são as escolhas do jogador que serão consideradas falhas dentro dos programas (de base e de uso) do jogo, portanto punidos com a perda de pontos e o retorno ao ponto de escolha. A linha mais grossa representa o programa narrativo em seu modelo de aquisição das modalidades necessárias, da consequente conjunção com o objeto de valor e devida sanção da personagem e do jogador.

Tradicionalmente, o percurso temporal-narrativo de jogos se desenvolve de modo onde a experiência do jogador avança relativa concomitância temporal com o desenvolvimento da narrativa. Alguns jogos que se encaixam neste modelo são Super Mario World (analisado por SILVA JUNIOR [2019]), Half-Life (analisado por JUUL [2004b]), God Of War 3 (analisado por CARDOSO [2015]) etc.

Porém, no caso de Overwatch e $L O L$, tal exemplo do gráfico não representa adequadamente o desenvolvimento do jogo. No caso dos jogos do corpus desta pesquisa, a experiência do jogador é temporalmente desconexa da narrativa do jogo. A cada nova partida que se inicia, as narrativas das personagens no universo ficcional já estão em pontos específicos (tendo como exemplo as seis narrativas descritas no item anterior), e as ações dos jogadores em suas partidas não alteram nem progridem a narrativa das personagens. Caso esta estrutura fosse representada, nos mesmos moldes do exemplo anterior, teríamos o seguinte gráfico:

Figura 11 - Gráfico temporal-narrativo para LOL e Overwatch, baseado no modelo de Juul. 


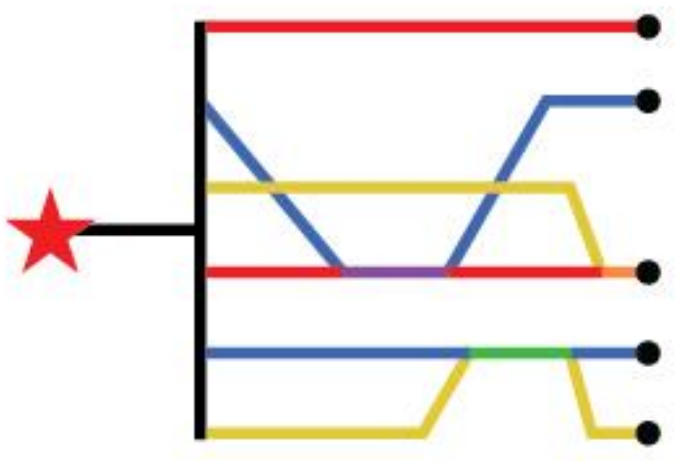

Fonte: imagem nossa.

No gráfico acima, cada linha colorida representa a narrativa de uma personagem, e os pontos pretos são o momento em que o jogo ocorre. Em vários momentos da narrativa do universo ficcional, as histórias das personagens convergem e se sobrepõe, com uma personagem podendo exercer um diferente papel actancial (destinador, anti-sujeito, adjuvante) na narrativa da qual outro personagem é sujeito.

Diferentemente dos jogos analisados por Juul, Cardoso ou Silva Júnior, onde acontece uma homologação entre jogador e personagem, nos moldes de 'Jogador $\leftrightarrow$ Enunciatário $\leftrightarrow$ Narratário $\leftrightarrow$ Personagem"” (SILVA JÚNIOR, 2019, p. 90), em LOL e Overwatch tal homologação acontece apenas durante as partidas, e estas não possuem extensão nas categorias de espaço e tempo da narrativa.

Outra prova desta ausência de sanção à narrativa das personagens pode ser vista nas telas de vitória/derrota que são exibidas ao fim de cada partida:

Figura 12 - Captura de telas de encerramento da partida em LOL. 


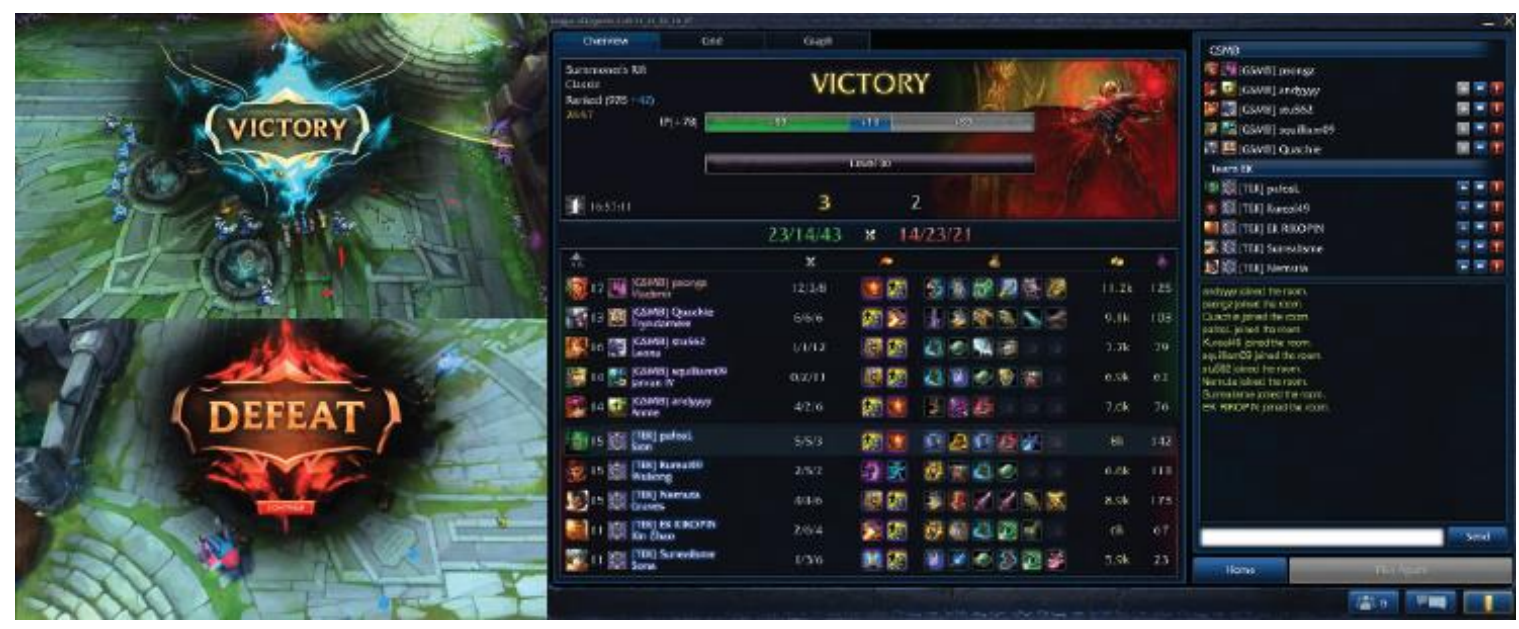

Fonte: imagem nossa, adaptada de Riot (2020).

Figura 13 - Captura de telas de encerramento da partida em Overwatch.

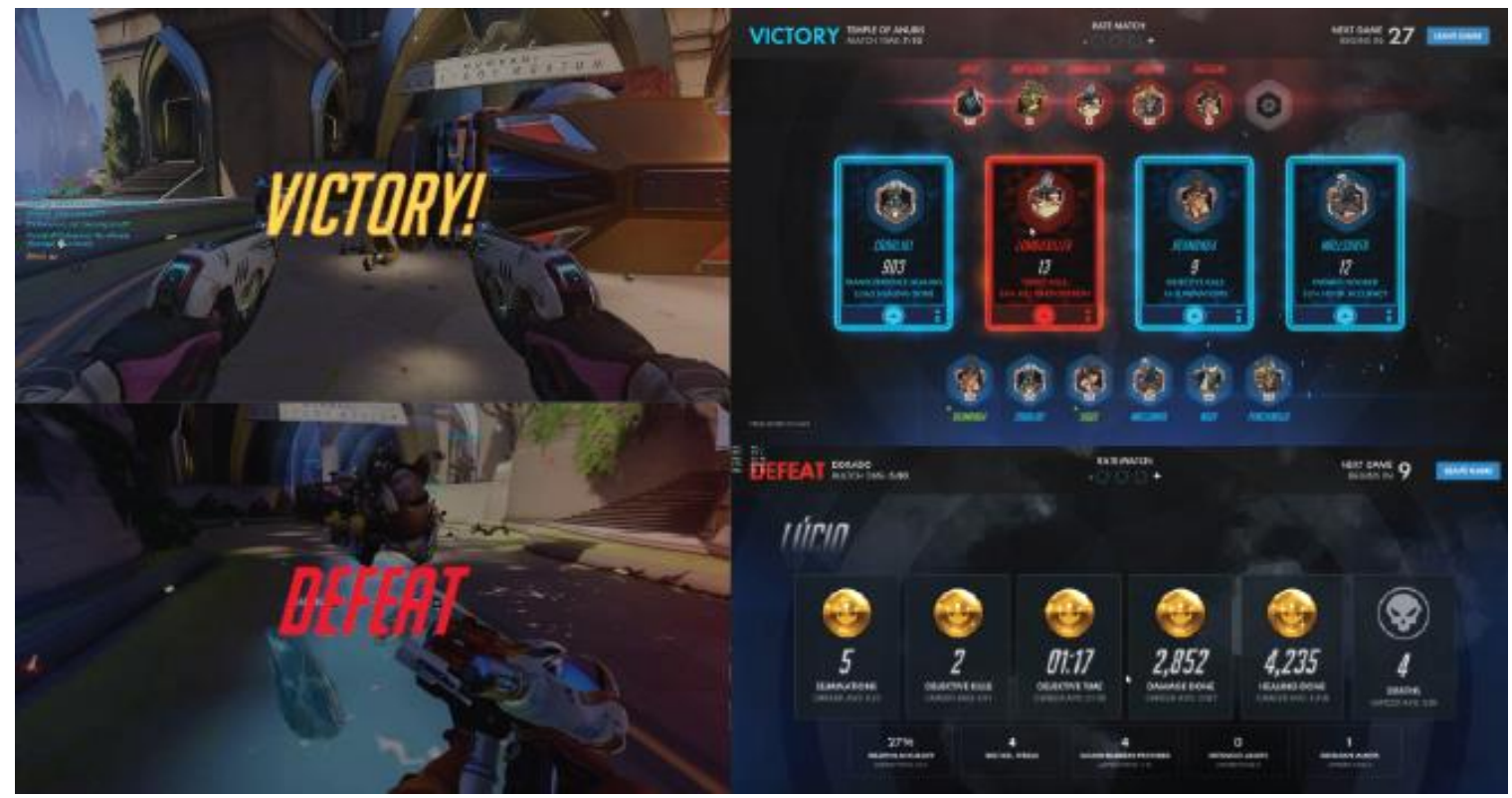

Fonte: imagem nossa, adaptada de Blizzard (2020).

Nas imagens acima, vemos que o jogador recebe as devidas sanções necessárias ao seu desempenho; à esquerda nas duas imagens, vemos que o destinador (jogo) informa ao destinatário (jogador) sobre a conjunção ou disjunção com o objeto de valor (vitória). À direita das duas imagens, temos a sanção positiva ou negativa que é fornecida ao jogador, na forma dos valores e estatísticas do seu desempenho, validando assim um estatuto de verdade para a sanção recebida. 
Esta pesquisa considera que a homologação entre jogador e personagem é, portanto, apenas parcial: o período em que jogador e personagens estão conjungidos no papel de sujeito dura apenas o momento da partida, e tal partida não possui dimensão temporal ou espacial dentro da narrativa da personagem. $\mathrm{O}$ jogador recebe a sanção de seu desempenho como sujeito competente, como analisado por SILVA JÚNIOR (2019).

A narrativa da personagem, porém, não é sancionada. Tal dinâmica permite que todas as personagens disponíveis se mantenham como opções de sujeitos em potencial: caso o jogo Overwatch optasse por encerrar a narrativa de suas personagens garantindo a exposição da conspiração contra a organização Overwatch, o objeto de valor de Jack Morrison (Soldado 76), isto faria do personagem Gabriel Reyes (Reaper) o anti-sujeito da narrativa "o jogo Overwatch".

Sobre a sanção, uma primeira conclusão parcial já pode ser traçada nesta pesquisa: A ausência de sanção em Overwatch e LOL demonstra que, enquanto no plano do jogo como atividade lúdica, os valores e as sanções pragmáticas e cognitivas são devidamente distribuídos aos jogadores, o mesmo não ocorre no plano da narrativa do universo ficcional.

No caso do plano da atividade lúdica, os contratos fiduciários e valores exigidos pelo destinador jogo são perceptíveis: o espírito de cooperação, a análise estratégica e uma certa maleabilidade tática. Quando o jogador cumpre sua performance de maneira satisfatória, é sancionado com a interface visual vencedora, seus pontos e recompensas. Quando não, surge a interface perdedora, bem como o não-aumento de acúmulo de pontos e recompensas, que ainda que não seja uma punição per se, o é em contraste com a vitória adversária.

No plano do universo ficcional, os valores considerados eufóricos pelo enunciador "jogo" se tornam de mais difícil visualização: a ausência da sanção do enunciador a respeito dos diversos programas de base sobrepostos e opostos, cada um pertencente a uma das personagens disponíveis aos jogadores, diminui a capacidade do discurso de recobrir figurativamente e tematicamente os percursos eufóricos e disfóricos. Esta ambiguidade ocorre pois, sendo a sanção o modo principal de expor os contratos e suas respectivas recompensas, é ele que claramente atribui os papéis de sujeito e anti-sujeito no caso de narrativas com dois percursos opostos e polêmicos. 
É importante apontar que a ambiguidade apontada nesta conclusão inicial não se confunde com "incompletude". Renato Razzino Ernica, no artigo "A incompletude narrativa como efeito de sentido nos jogos digitais (2014), aponta para o fato de que alguns pesquisadores criticam certos jogos pelo fato de que suas narrativas são "incompletas", como se deixassem elementos mal apresentados e fossem narrativas fracas.

$\mathrm{O}$ autor argumenta que este equívoco ocorre quando tenta-se analisar jogos de videogame com o ferramental de outros meios expressivos, pois "um jogo não apresenta uma narrativa separada dos elementos formais que o caracterizam, mas sim cria a narrativa por meio deles" (ERNICA, 2014, p. 51). Ainda que, tradicionalmente, as narrativas pressuponham um fechamento para poderem ser observadas como uma unidade de sentido, o autor se utiliza do ferramental proposto por Janet Murray (1997), onde a estética do ambiente digital é baseada em três pontos básicos:

- Imersão: Segundo a autora, "A experiência de ser transportado para um lugar primorosamente simulado é prazerosa em si mesma, independentemente do conteúdo da fantasia. Referimo-nos a essa experiência como Imersão" (MURRAY, 2003, p. 102). A imersão é a capacidade do ambiente digital de "mergulhar" o jogador dentro de um universo simulado.

- $\quad$ Agência: Segundo a autora, "A agência é a capacidade gratificante de realizar ações significativas e ver o resultado de nossas decisões e escolhas" (MURRAY, 2003, p. 127). Vale apontar que a agência envolve os resultados das ações diretas do jogador dentro do jogo. Murray considera que variáveis automatizadas, ativadas à medida que o jogo progride, não são elementos de agência, mesmo sendo elementos interativos.

- $\quad$ Transformação: Murray considera que a transformação é a capacidade que o meio digital oferece para as alterações dos elementos da narrativa, sem as consequências equivalentes de mudanças similares fora do meio digital. Segundo a autora, "Nos jogos de computador, não tomamos decisões para a vida inteira ou por toda uma civilização; quando as coisas dão errado, ou quando simplesmente queremos uma outra versão da mesma experiência, voltamos para o inícios e começamos de novo" (MURRAY, 2003, p. 153). 
Razzino Ernica, a partir das observações propostas por Murray, afirma que o "fechamento" tradicional é substituído pela saturação de tais elementos: o jogo acaba não quando a narrativa se encerra, mas quando os prazeres citados acima se tornam previsíveis e incapazes de propiciar ao jogador sensações de descobrimento (o território do tédio, segundo o conceito de flow, proposto por Cziksentmihalyi).

Para o autor, portanto, estas características colocam tais sistemas de jogo ${ }^{32}$ como possuidores de uma estética da incompletude, onde o fechamento da narrativa do jogador se dá pela saturação, pois:

Baseados em uma estrutura repetitiva de temas e figuras, no que se refere ao plano do conteúdo, e de mecânica de jogo e estímulos sensoriais, no plano da expressão, os diferentes objetivos e modalidades não precisam ser completos individualmente para que se passe do desconhecido ao conhecido (ERNICA, 2014, p. 72)

Esta pesquisa considera que, do ponto de vista da ludologia observada em $L O L$ e Overwatch, que a ausência de uma conclusão das narrativas emaranhadas das personagens do universo ficcional é na verdade um convite: como os jogadores interagem nos fóruns, estes mesmos espaços fornecem uma maior "vida útil" aos jogos, pois é nos fóruns que os jogadores podem experimentar novas formas de imersão (pela discussão sobre o universo do jogo), agencia (discutindo pontos da jogabilidade e pressionando as desenvolvedoras por mudanças) e transformação (onde podem compartilhar e experimentar novas ideias de interação com o universo do jogo).

Tais modalidades de interação não seriam possíveis apenas dentro do espaço do jogo em si, e acabam por transbordar tal espaço. Nas palavras de Razzino Ernica:

Esse conteúdo latente, denunciado pelas personagens que vagam pelos cenários, pelos caminhos fechados, pelas referências a um passado remoto ou por meio das esperanças depositadas em um futuro, penetra no jogador em sua vivência narrativa e adquire sentido no ato discursivo de jogar, que, como já dito, preenche

\footnotetext{
32 Aqui, o autor emprega um termo utilizado por Salen \& Zimmerman (2016a) para falar de elementos como o baralho, onde uma estrutura lúdica serve de suporte para diversos jogos. O autor usa o termo sistema de jogos pois a grande variedade de configurações lúdicas que os hardwares de jogos digitais possuem, acabaram por criar categorias de jogos digitais com configurações narrativas muito diferentes da noção tradicional e leiga do termo. Guardadas as devidas proporções, $L O L$ e Overwatch podem ser considerados sistemas de jogo, pois dentro da mesma plataforma há diversas modalidades de jogo, já explicadas anteriormente neste capítulo.
} 
as lacunas com estruturas narrativas figurativizadas a partir do conhecido sobre o gênero, ampliando constantemente o universo ficcional ao lançar alhures os seus limites, mantendo a narrativa sempre em devir, sem qualquer possibilidade de encerramento (ERNICA, 2014, p. 73)

Já do ponto de vista da semiótica e do percurso gerativo de sentido, a sanção "em aberto" a respeito das narrativas das personagens de $L O L$ e Overwatch opta por não oferecer ao seu leitor marcas claras da ideologia do destinador-manipulador. Quando este actante não sanciona os sujeitos e anti-sujeitos, aplicando os reconhecimentos, punições e recompensas adequados, esconde-se de forma mais intensa os valores ideológicos que regem a construção do discurso e organizam sua axiologia. A ausência da sanção de um destinador em um discurso acaba por fortalecer os percursos de anti-sujeitos e anti-destinadores em relação polêmica com o discurso. Tal situação será abordada em mais detalhes no próximo capítulo.

\subsubsection{A rede de equilíbrio do universo ficcional dos jogos}

Nos jogos de videogame construídos sobre um único programa narrativo linear, o desenvolvimento do universo ficcional possui um foco em torno do protagonista (sujeito da narrativa). Com isso, a criação ou desenvolvimento dos elementos do universo ficcional é feita a partir das exigências do programa narrativo do jogador/protagonista ${ }^{33}$.

Para exemplificar esta condição dos jogos de programa narrativo único e linear, usaremos o jogo Super Mario World, lançado em 1990 e analisado por Mario Silva Júnior em um artigo de 2019. Este jogo conta a história de Mário, o protagonista, que descobre que sua amiga princesa Peach é sequestrada por Bowser, e levada para o Reino do Dinossauro. Indo ao resgate da Princesa, Mario encontra a casa de Yoshi e descobre, por intermédio de uma carta deste, que o dono da casa

\footnotetext{
${ }^{33}$ A relação entre os elementos de um universo fictício dentro de uma narrativa e sua utilidade para a mesma, é um efeito que transcende os videogames, sendo um elemento presente nas narrativas de quadrinhos, filmes e literatura. $\mathrm{O}$ escritor Anton Chekhov propõe este princípio a um colega escritor, S. Shchukin, em troca de correspondências publicadas em 1911 por Shchukin, no livro Memoirs. Este princípio ficou inclusive conhecido como "Chekhov's Gun" (A arma de Chekhov). TVTROPES. Checkov's Gun. TvTropes. Disponível em: <https://tvtropes.org/pmwiki/pmwiki.php/Main/ChekhovsGun>. Acesso em: 22 abr. 2020.
} 
saiu em busca de seus amigos, que também foram aprisionados por Bowser. Assim, de acordo com Mário, o autor do artigo:

Objeto valor (princesa), oponente (Bowser) e adjuvante (Yoshi) definidos, é controverso tentar esclarecer a manipulação que leva Mário a cumprir a ação destinada [...] Em geral, é possível inferir que Mário cumpre seu destino por que deve, ele é o herói e a esperança final. (SILVA JÚNIOR, 2019, p. 92-93)

Não há a necessidade de se problematizar o desempenho do antagonista Bowser como regente, muito menos de compreender a interpretação dos demais habitantes da ilha a respeito da situação, pois nenhuma destas informações tem relação com o programa narrativo da personagem/jogador.

No caso dos jogos de nosso corpus, porém, tal dinâmica se altera um pouco. Um dos antisujeitos de Jack Morrison, Gabriel Reyes, é o herói Reaper, assim como é também um dos heróis de Overwatch Ana Amari, a mãe e destinadora de Pharah. Zed, anti-sujeito do personagem Shen, é um dos campeões de $L O L$, assim como o é o assassino que tenta matar Katherine. A parceira de Caitlin em Pitlover, Vi, também é uma campeã, sujeito de sua própria narrativa. As histórias das personagens de cada um dos jogos do nosso corpus se relacionam na criação de um universo ficcional coeso.

Neste ponto, é prudente nos referirmos a este grupo de protagonistas, sujeitos disponíveis para serem utilizados pelos jogadores a cada começo de jogo, como elenco. Esta nomenclatura será baseada nos estudos de Umberto Eco, que em seu livro A Vertigem das Listas, apresenta a seguinte definição:

Existe, contudo, um outro modo de representação artística que ocorre quando não se conhecem os confins do que se deseja representar (...) para torná-la compreensível, perceptível de alguma maneira, se elencam suas propriedades (...) feito de objetos talvez numeráveis, mas que nós não conseguimos numerar (...) chamaremos esta modalidade representativa de lista, elenco ou catálogo. (ECO, 2010, p. 15-17)

Se este elenco representa uma totalidade dificilmente numerável, o que esta lista de protagonistas dos dois jogos de nosso corpus representa? A resposta é uma isotopia de totalidade e igualdade dentro do universo ficcional. Este elenco de heróis e campeões não podem ser olhados apenas do ponto de vista da narrativa do universo ficcional e suas respectivas isotopias, mas 
também em relação aos elementos de programação, publicidade e game design que constituem o próprio universo do jogo.

Como explicado no capítulo anterior, os jogos de $L O L$ e Overwatch possuem um elenco de personagens em constante atualização, onde gradualmente são adicionados novos representantes. Ao pensarmos no game design e na programação do jogo, é perceptível que uma das principais funções da inclusão de novos personagens no jogo é a de equilibrar as opções estratégicas de atuação dos personagens jogadores, enquanto do ponto de vista da narrativa, os principais motivos para a inclusão de novas personagens é aprofundar os detalhes do universo ficcional, bem como abrir novas frentes narrativas para exploração.

Tal equidade de condições, tanto na mecânica do jogo quanto na representação, é uma preocupação recorrente dentro do universo dos jogos e da Ludologia num geral. O antropólogo Roger Caillois, em Os Jogos e os Homens (1958) fala sobre "A força dos campeões deve ser equilibrada para que cada um possa defender sua oportunidade até o fim" (1990, p. 27). Caillois propõe um conjunto de categorias para divisão dos jogos, num desdobramento mais estruturado do que o trabalho filosófico de Johan Huizinga em Homo Ludens. Nestas categorias, os jogos de nosso corpus podem ser incluídos na categoria de Agôn, e segundo o autor, nesta categoria:

Há todo um grupo de jogos que aparece sob a forma de competição, ou seja, como um combate em que a igualdade de oportunidades é criada artificialmente para que os adversários se defrontem em condições ideais, susceptíveis de dar valor preciso e incontestável ao triunfo do vencedor. Trata-se sempre de uma rivalidade que se baseia numa única qualidade, excedendo-se em limites definidos e sem nenhum auxiliar exterior, de tal forma que o vencedor apareça como sendo o melhor, numa determinada categoria de proezas (CAILLOIS, 1990, p. 33-34).

Ainda que se possa argumentar que as descrições de Caillois sejam de uma época muito anterior ao surgimento dos jogos digitais, pesquisadores mais atuais, como Katie Salen e Eric Zimmerman, retomam o pensamento de Caillois em seu Regras do Jogo (2004). Os dois pesquisadores não apenas concordam com o antropólogo francês, como desenvolvem ainda mais seu pensamento, argumentando que:

Na vida real, os conflitos e lutas enfrentados nunca são claramente articulados e entendidos como em um jogo. A ideia de que os jogadores estão entrando em um conflito justo, em que não serão enganados pelo jogo em si, é um componente fundamental para a atitude lúdica. Mesmo que os jogos possam ter elementos de 
incerteza, a estrutura dentro da qual essa incerteza ocorre é conhecida de antemão (SALEN \& ZIMMERMAN, 2016a, p. 158)

Tanto Caillois quanto Salen e Zimmerman também concordam que, apesar do ideal de que “dentro do círculo mágico, os jogadores vivem uma espécie de igualdade e justiça que não existe fora dos jogos" (SALEN \& ZIMMERMAN, 2016a, p. 160), a igualdade absoluta não é possível de ser atingida, mas é importante que os jogadores envolvidos no jogo acreditem que o sistema do jogo é igualitário o suficiente. Para garantir tal sensação de igualdade, certas técnicas podem ser utilizadas, como por exemplo "ser estabelecida por um handicap entre jogadores de diferentes níveis, o que quer dizer que, na igualdade de oportunidades incialmente estabelecida, se cria uma desigualdade secundária, por proporcional à suposta força relativa dos participantes" (CAILLOIS, 1990, p. 34).

Outro modo de criar desigualdades para garantir uma igualdade de possibilidades na busca da vitória é descrita por Jesper Juul em Half-real (2005), onde o autor discorre sobre a Triangularidade, termo cunhado por Chris Crawford ${ }^{34}$ (1982) para uma dinâmica específica:

A forma mais simples de [triangularidade] é encontrada nos jogos em que três tipos de unidades estão presas em uma relação circular. Nesse caso, o arqueiro é mais forte que o guerreiro, o guerreiro mais forte que o bárbaro e o bárbaro mais forte que o arqueiro. (JUUL, 2019, p. 106).

Pensando em uma variação mais complexa (e mais adequada ao corpus desta pesquisa), o autor prossegue com uma descrição sobre modos de projetar o jogo:

Isso significa projetar o jogo de modo que cada unidade tenha forças e fraquezas em vários eixos diferentes: um arqueiro pode ser fraco em batalha corpo-a-corpo, forte em distância, mas lento para se mover. Outra unidade pode ser forte no corpo-a-corpo, mas fraca na distância. A chave é ter certeza de que há um número diferente de eixos que se sobrepõe ao longo dos quais as unidades possam ser dispostas [...] com o design ortogonal de unidades, muitos tipos diferentes de gameplay inesperados podem acontecer. (JUUL, 2019, p. 106).

\footnotetext{
34 Esta dinâmica foi descrita por outros autores, e suas nominações são usadas pro Juul no mesmo trecho, a Triangularidade foi chamada de "escolha semi-interessante” por Bernd Kreimeier (2002), "diferenciação ortogonal de unidades" por Harvey Smith (2003) e "ações intransitivas” por Andrew Rollings e Dave Morris (2000).
} 
Como exemplo desta busca pela igualdade dentro dos jogos de nosso corpus, podemos citar o lançamento da personagem Echo, dentro do universo de Overwatch, em março de 2020. Nas análises em reportagens ${ }^{35}$ ou em vídeos ${ }^{36}$, os críticos e jogadores se dedicam a analisar dois pontos principais: o primeiro é sobre como as habilidades da personagem desequilibram ou reequilibram a dinâmica das partidas (sua habilidade suprema permite copiar as habilidades de outros heróis, significando mudanças no balanço de habilidades disponíveis no time durante uma partida). $\mathrm{O}$ segundo ponto analisado se refere a quais segredos da narrativa do universo fictícios serão criados ou desvelados. O vídeo de introdução de Echo mostra qual foi o fim de uma das personagens que havia fundado a agência Overwatch, a Dra. Mina Liao, que já era conhecida dos fãs por ter sido citada na história de outros heróis.

Fora da esfera direta de ação do jogo, é possível afirmar que outro foco de discussão é sempre os aspectos das isotopias com o mundo natural que a personagem representa (no caso de Echo, houve críticas sobre a necessidade de criar uma personagem, que é um robô, mas possui uma silhueta destacadamente feminina, já que o mercado de jogos tem uma longa polêmica sobre o machismo e a hiper sexualização de personagens femininas ${ }^{37}$ ).

Tendo como referência o corpus desta pesquisa e outros jogos similares a eles, pode-se afirmar que os três pontos levantados na apresentação de Echo são os principais motivos levados em consideração por desenvolvedores, fãs e jogadores ao observar cada atualização de $L O L$ e Overwatch: as mudanças dentro da mecânica do jogo, as mudanças dentro das narrativas e as isotopias sugeridas entre o universo do jogo e os valores do mundo natural.

35 BEHNKEN, Breno. Echo no Overwatch: saiba tudo sobre a nova personagem jogável do game. Globo.com. 15 abr. 2020. Disponível em: <https://www.techtudo.com.br/noticias/2020/04/echo-no-overwatch-saiba-tudo-sobre-a-novapersonagem-jogavel-do-game.ghtml >. Acesso em: 25 abr. 2020.

${ }^{36}$ COORUJA. NOVO HERÓI ECHO! Primeiras Impressões e Testando Habilidades! Overwatch Brasil. Youtube. Disponível em: 〈https://www.youtube.com/watch?v=wGiWOqj-CH4>. Acesso em: 25 abr. 2020.

${ }^{37}$ TRENT, John F. Overwatch's Latest Hero Echo Under Assault For Looking Like Na Attractive Female. Bounding into Comics. 30 mar. 2020. Disponível em: <https://boundingintocomics.com/2020/03/30/overwatchs-latest-heroecho-under-assault-for-looking-like-an-attractive-female/>. Acesso em: 27 abr. 2020. 


\subsection{Das variantes específicas ao corpus dos jogos}

\subsubsection{A mudança no equilíbrio das mecânicas}

Do ponto de vista das mudanças da mecânica, o aumento de intensidade na relação entre os jogadores e os jogos do corpus não se limita apenas ao momento em que uma personagem nova é lançada, mas é antes uma relação de equilíbrio fluído, posto à prova a cada campeonato ou atualização dentro do jogo. Para exemplificar esta relação, vamos abordar alguns exemplos encontrados em $L O L$, como a utilização conjunta das personagens Master Yi e Taric, e a utilização heterodoxa da personagem Soraka.

No decorrer do ano de 2018, a partir de experiências realizadas nos campeonatos chineses de $L O L^{38}$, uma tática de jogo começou a se popularizar dentro das partidas de $L O L$ por todo o mundo: Taric, um campeão híbrido que é um Tanque do tipo Protetor e também um Suporte do tipo Encantador, fica posicionado na rota do meio do mapa, controlando e prendendo a movimentação dos campeões, criaturas e tropas que circulam por lá, enquanto Master Yi, um campeão Retalhador do tipo Duelista, circula pela Selva, abatendo todas as criaturas da selva e também as criaturas/tropas/campeões que estiverem presos nas magias de Taric na rota do meio.

Com esta tática, no período final da partida, é comum se ter um Master Yi extremamente poderoso e com condições de enfrentar todas as defesas do time adversário sozinho, enquanto o enfraquecido Taric (que não combateu diretamente nenhum inimigo, portanto não acumulou pontos nem poderes) se limita a usar suas habilidades de suporte para ajudar a proteger Master Yi.

Tal tática se tornou tão eficaz, que a dificuldade de vencê-los, bem como a incrível facilidade para ganhar partidas desta forma, se tornaram assunto recorrente entre os jogadores

\footnotetext{
${ }^{38}$ LEE, Julia. The Taric and Master Yi composition, explained. Rift Herald. 29 mai.2018. Disponível em: <https://www.riftherald.com/LOL-gameplay/2018/5/29/17405284/taric-master-yi-LOL>. Acesso em: 28 abr. 2020.
} 
profissionais $^{39}$ e também entre jogadores comuns ${ }^{40}$, com alguns reclamando do desequilíbrio do balanço do jogo enquanto outros elogiavam a "reviravolta" que esse domínio causava em uma dinâmica de jogo que parecia "monótona".

Após uma alta popularização desta tática, a Riot, empresa que desenvolve o $L O L$, decidiu aplicar um $\mathrm{Nerf}^{41}$ nos dois personagens no Patch $8.14^{42}$, onde a alteração das normas de coleta de pontos e ouro na selva acabou por diminuir a eficácia desta estratégia. Este Nerf aplicado pela desenvolvedora Riot causou novamente reações mistas na comunidade de jogadores.

Outro exemplo similar aconteceu com a campeã Soraka, um Suporte do tipo Encantador. Durante o ano de 2019, esta personagem começou a ser constantemente utilizada na rota de Topo e, devido a suas opções de recuperação de dano e aumento de velocidade, bem como a possibilidade de comprar melhorias antes dos demais jogadores. Tal tática permitiu que times que a possuam como personagem na rota de topo atinjam uma taxa de vitória de 56\%, considerada muito alta pelos desenvolvedores, que em fevereiro anunciaram que irão aplicar um Nerf em Soraka num Patch próximo $^{43}$.

Nestes e em outros casos em que os desenvolvedores interferem na programação do jogo para corrigir o equilíbrio entre tais mecânicas, as opiniões da comunidade de jogadores e fãs costumam ser divididas: há jogadores que veem no uso excessivo de meta ${ }^{44}$ uma limitação

${ }^{39}$ BLITZ ESPORTS LOL. Doublelift explains the gold funneling strat (and why he hates it) - LoL Pro Tips. Youtube. Disponível em: <https://www.youtube.com/watch?v=GaGoyIUHs60>. Acesso em: 28 abr.2020.

40 BLIZZARD. Mecânicas de jogo: Taric e Master Yi. League of Legends. Disponível em: <https:// forum.br.leagueoflegends.com/t5/Mec\%C3\%A2nicas-de-Jogo/Taric-e-Master-YI/td-p/236011>. Acesso em: 28 abr. 2020 .

41 Termo utilizado para se referir à diminuição da força de algum elemento de um jogo. Descrito em detalhes no glossário no fim da dissertação.

42 TEIXEIRA, Eric. Rioter explica a solução temporária para o afunilamento de recursos que virá no patch 8.14. Mais ESports. 12 jul. 2018. Disponível em: <https://www.maisesports.com.br/solucao-temporaria-afunilamento-derecursos-8-14/>. Acesso em: 28 abr. 2020.

${ }^{43}$ RICHMAN, Olivia. Major Soraka nerf coming to League of Legends in near future. Win.gg. Disponível em: <https://win.gg/news/3738/major-soraka-nerf-coming-to-league-of-legends-in-near-future>. Acesso em: 28 abr. 2020.

${ }^{44}$ Meta é a abreviação de Metagaming, conceito que pode ser definido como as convenções das práticas de jogo. Descrito em detalhes no glossário no fim da dissertação. 
desnecessária à criatividade do jogo, enquanto outros argumentam que o meta serve para garantir maior igualdade de condições a todos os jogadores. Na prática, a manutenção ou não do meta não possui relação direta com a manutenção do equilíbrio do jogo, pois nos exemplos citados, o caso de Soraka é uma transgressão do meta (o uso de uma campeã de suporte para uma função de combate solo) enquanto o caso de Master Yi e Taric é um desequilíbrio que ocorre dentro do meta do jogo.

Para entendermos tal pluralidade de opiniões, podemos observar argumentos ludológicos e semióticos para tanto. Do ponto da Ludologia, autores como Jesper Juul e Salen \& Zimmerman se referem às ideias do psicólogo húngaro Mihaly Csikszentmihalyi a respeito do Flow (Fluxo), como um referencial teórico para designers de jogos.

O conceito de Flow teoriza que, durante uma atividade, seu praticante pode entrar num estado emocional e psicológico de felicidade controlada e engajada, equilibrando a sensação de controle com uma parcial falta de controle de uma situação. Especificamente para a área dos jogos, Salen \& Zimmerman destacam que

Csikszentmihalyi traça a experiência de uma pessoa em dois eixos. Um eixo representa o grau de desafio que uma atividade oferece. $\mathrm{O}$ outro eixo representa as habilidades que um participante possui (...) de um lado da faixa está o estado de ansiedade, onde os testes da atividade ultrapassam as habilidades do participante. No outro lado está o tédio, o estado no qual as habilidades do jogador superam o desafio que a atividade pode proporcionar." (SALEN \& ZIMMERMAN, 2016b, p. 72).

Csikszentmihalyi, em seu livro Flow: The Psychology of Optimal Experience (1990) constrói um gráfico que visa demonstrar o funcionamento do Flow entre os momentos de ansiedade e tédio:

Figura 14 - O gráfico de Flow 


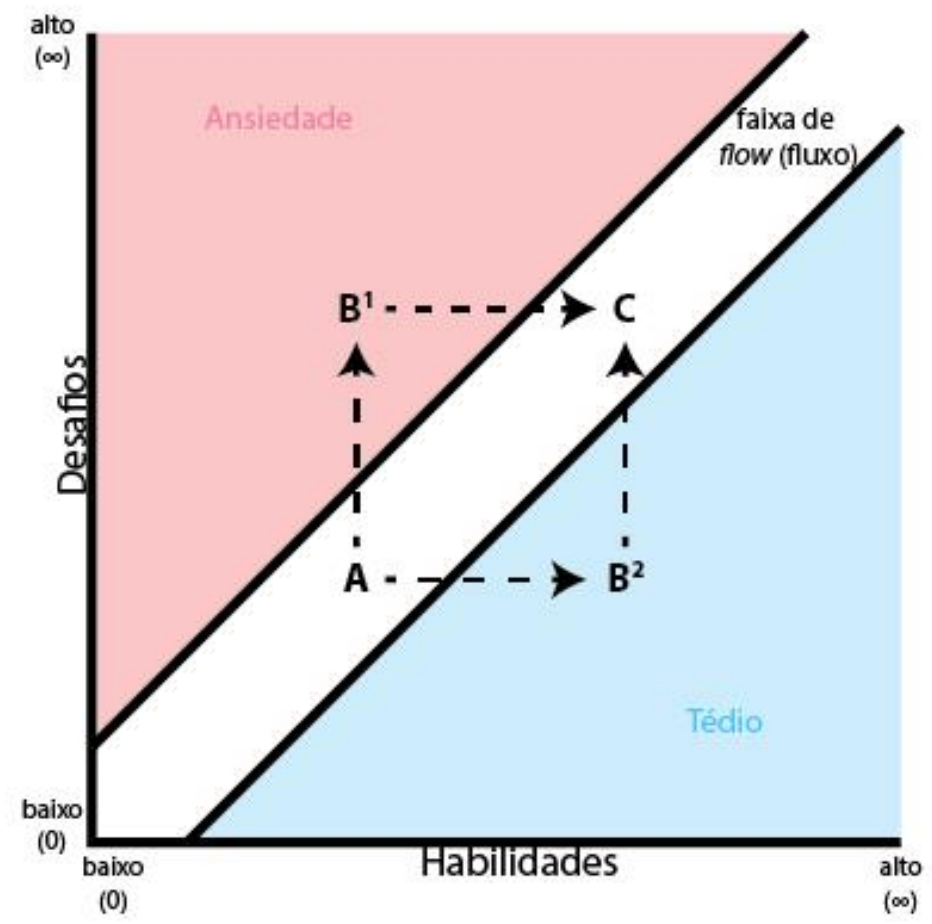

Fonte: imagem nossa, adaptada de Csikszentmihalyi (2008).

É importante termos em mente este "ideal" do design de jogos, onde o jogador não pode ser consecutivamente arrebatado por algo além de sua capacidade, nem deixado em sua zona de conforto indefinidamente, não é um estado constante, mas um ponto ideal de referência. Em um jogo que se utilize bem deste conceito, o jogador deve circular temporariamente entre as zonas de tédio (azul, no gráfico 1) e ansiedade (vermelho, no gráfico 1) apenas como incentivos, para depois voltar ao equilíbrio. O jogador pode ser desafiado além de sua capacidade, e então superar a adversidade e receber ofeedback de estar novamente no controle (no gráfico 1: o caminho $\mathrm{A} \rightarrow \mathrm{B}^{1}$ $\rightarrow$ C) ou, ao contrário, sentir- se como o "dono" do espaço em que circula, até encontrar um novo desafio para vencer (o caminho $\mathrm{A} \rightarrow \mathrm{B}^{2} \rightarrow \mathrm{C}$ ).

Tomando como base este modelo, os game designers buscam criar uma experiência que permita ao jogador realizar estes caminhos $\left(\mathrm{A} \rightarrow \mathrm{B}^{1} \rightarrow \mathrm{C}\right.$ e $\left.\mathrm{A} \rightarrow \mathrm{B}^{2} \rightarrow \mathrm{C}\right)$. Porém, apenas a existência deste referencial não promove uma experiência única para todos os jogadores, pois como o próprio autor aponta:

É importante, entretanto, não cair na falácia mecanicista e esperar que, apenas porque uma pessoa está objetivamente envolvida em uma atividade de flow, ela necessariamente terá a experiência apropriada. Não são apenas os desafios "reais" 
apresentados pela situação que contam, mas aqueles dos quais a pessoa está ciente. (CSIKSZENTMIHALYI, 2008, p. 75)

A partir da ciência do fato de que há uma relação dinâmica entre os estados de ansiedade e tédio no ato de jogar videogame, pode-se entender como isto pode ser considerado uma experiência individual narrativa. No artigo Narratividade e Aspectualização de Silva Júnior, o autor propõe uma interpretação semiótica para a experiência narrativa do ato de jogar:

Superar essas adversidades depende das reações do narratário, medidas em duração, de ordem extensa, e em potência, de ordem intensa, pensando na perspectiva tensiva da semiótica do discurso. Trata-se do quão rapidamente ele corre, foge, desvia, ataca etc. É preciso ajustar-se às oscilações interativas que os perigos configuram, também medidas em extensidade e em intensidade. (SILVA JÚNIOR, 2019, p. 105).

A partir do pensamento do autor, pode-se afirmar que o ato de jogar é uma experiência narrativa, onde o jogador ajusta suas competências para suprir os programas de uso do jogo, e assim conquistar as habilidades necessárias para buscar o programa de base, que é a vitória. No caso de LOL e Overwatch, estes programas de uso são o entendimento das mecânicas do jogo, bem como o domínio das relações de Triangularidade descritas por Juul e que ocorrem entre as habilidades de todo o elenco de campeões/heróis.

Como analisado no item anterior, esta pesquisa considera que as partidas que ocorrem nos jogos de nosso corpus são pontos estáticos dentro da narrativa do universo ficcional. Porém, dentro do modelo narrativo do ato de jogar descrito por Silva Júnior, a narrativa de ajuste é de andamento regular. Cada partida é uma repetição do ponto de vista da narrativa do universo ficcional, porém uma nova experiência do ponto de vista da experiência de jogo, onde surgem novos jogadores e novas combinações de campeões. Como os desafios a cada partida mudam, a possibilidade de que a repetição de um mesmo desafio não-superado canse um jogador inexperiente diminui.

De forma a resumir a corrente de raciocínio iniciada neste item: a experiência de cada jogador consiste na superação de desafios e aquisição de modalidades durante seu ajustamento à narrativa do jogo. É uma guia utilizada por desenvolvedores de jogos que se mantenha a experiência do jogador dentro da faixa do flow de Csikszentmihalyi, onde o jogador não passe muito tempo pressionado por desafios que não possa superar, nem muito tempo entediado com desafios que não o movem. Para garantir que vários perfis de jogadores diferentes possam 
experienciar este flow dentro de uma estrutura única do jogo, são desenvolvidos diferentes personagens, classes, habilidades, pontos importantes em mapas, estratégias de triangularidade e outras ferramentas que dinamizem as opções estratégicas dos jogadores. Por fim, quando a comunidade do jogo começa a incorporar táticas que desequilibram estatisticamente este estado de flow, criando gargalos estratégicos invencíveis/imperdíveis, os desenvolvedores interferem diretamente na mecânica do jogo, através de novas personagens ou cenários, Patchs, Buffs ou Nerfs.

O objetivo desta dinâmica é garantir a igualdade de condições, tão importante à atividade lúdica, como foi demonstrado pelas leituras de Caillois, Juul e Salen \& Zimmerman.

\subsubsection{Das variantes: a complexificação narrativa}

A cada nova inclusão de personagens, ou expansão do universo ficcional dos jogos do corpus de pesquisa, sempre se busca que estas adições equilibrem uma espécie de representatividade ficcional, onde os campeões e as coletividades que eles representam sejam proporcionalmente representados. Vemos esta tendência a uma globalidade ficcional desde jogos antigos, como o Street Fighter 2 (1991):

Figura 15 - Tela de seleção de personagens em Super Street Fighter 2 


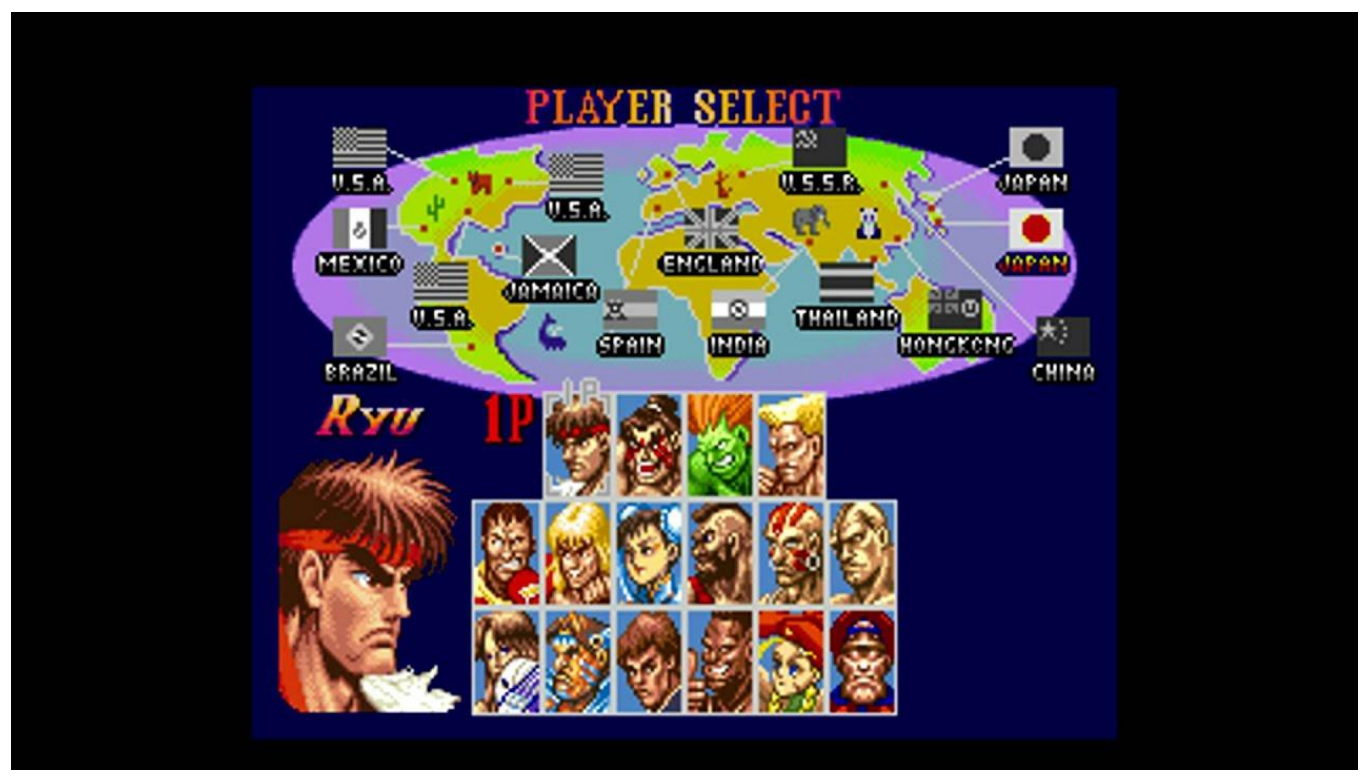

Fonte: Capcom $(1993)^{45}$.

O conceito de uma competição que reúna os melhores do mundo para definir um campeão "indiscutível" não é nova e nem se resume apenas a jogos de videogame: O próprio conceito dos jogos olímpicos, que congregam a grande maioria dos países do mundo, possuem a excelência ${ }^{46}$ como um de seus valores-chave e ainda o lema "citius, altius, fortius", traduzido do latim como "mais rápido, mais alto, mais forte"47. Novamente aqui temos o Agôn de Caillois como referencial.

A forma de construção dos lutadores do universo ficcional que acabamos de ver em Street Fighter 2 se repete em Overwatch, onde o universo fictício desenvolvido pela empresa Blizzard visa mimetizar o mundo natural: uma geopolítica similar à que pode ser vista pelos jogadores nos noticiários e livros de história, porém com toques de ficção científica. A distribuição das personagens é então feita da seguinte forma:

Figura 16 - Colagem, representando as nacionalidades das personagens dentro do universo ficcional do jogo Overwatch.

\footnotetext{
${ }^{45}$ Disponível em: <https://www.youtube.com/watch?v=C3MhOKsMLno>. Acesso em: 09 mar. 2021.

46 OLYMPIC COMITEE. Who We Are. Olympic.com. Disponível em: <https://www.olympic.org/about-iocolympic-movement>. Acesso em: 07 mai. 2020.

47 OLYMPIC COMITEE. The Olympic Motto. Olympic.com. Disponível em: <https://www.olympic.org/theolympic-motto>. Acesso em: 07 mai. 2020.
} 


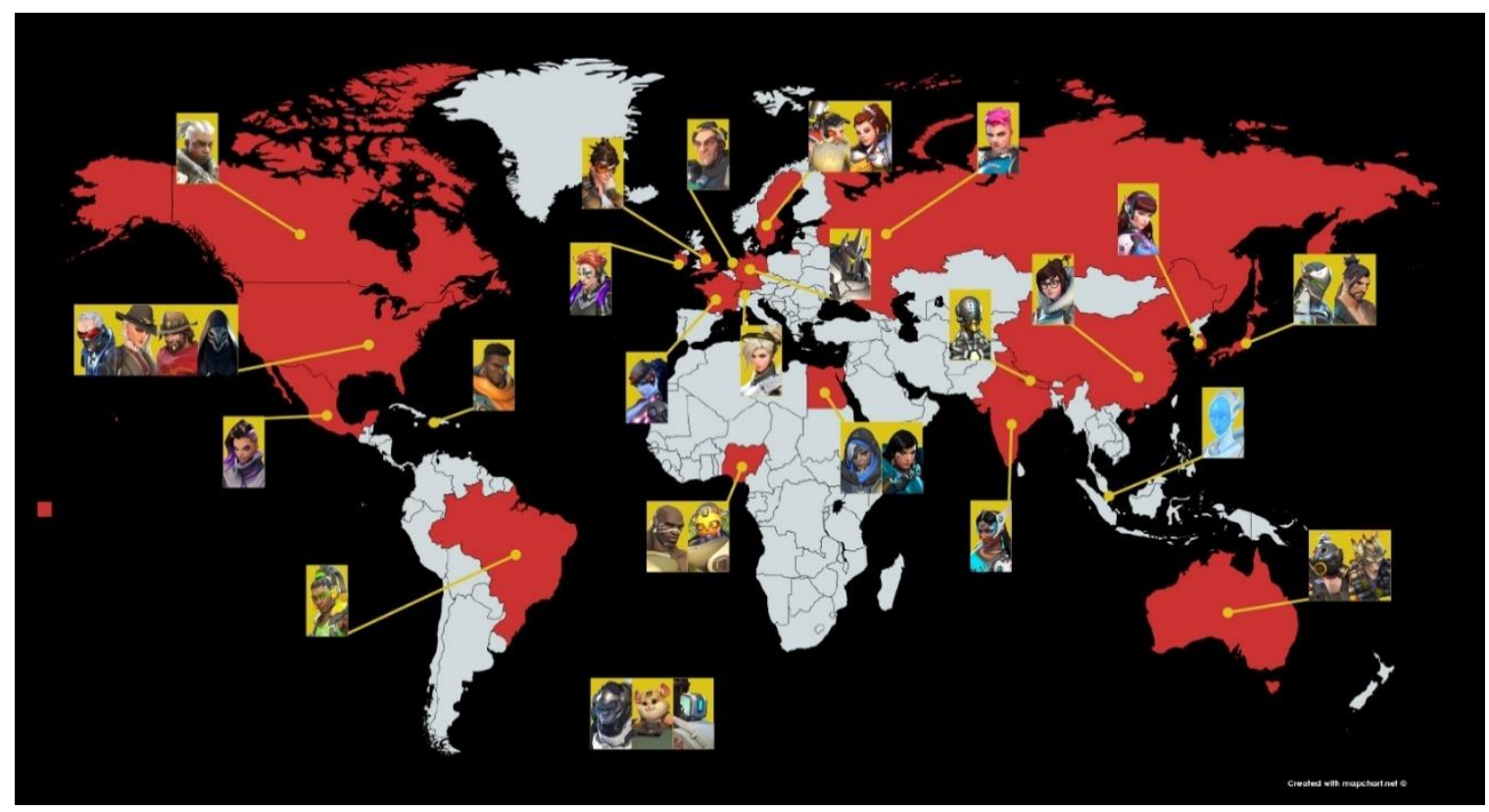

Fonte: imagem nossa, adaptada de Blizzard (2020).

Até Maio de 2020, os 33 campeões já conhecidos pela comunidade são divididos em 21 países (EUA, Canadá, México, Brasil, Haiti, Nigéria, Egito, França, Irlanda, Inglaterra, Holanda, Suécia, Suíça Alemanha, Rússia, China, Índia, Nepal, Singapura e Austrália), enquanto 3 campeões são afiliados a localizações não-geopolíticas (e características do modelo de ficção científica), como uma fábrica autônoma de uma nação robótica e uma colônia lunar de pesquisa científica. Tal distribuição de representações ${ }^{48}$ auxilia a criar uma isotopia de globalidade para os combates que permeiam as narrativas, bem como para o resultado das vitórias dos jogadores.

\footnotetext{
${ }^{48}$ Quando esta pesquisa se refere a um conceito de globalidade na representação nos jogos citados, o faz a partir do referencial do antropólogo argentino Néstor Garcia Canclini. De acordo com os apontamentos feitos pelo autor na obra Diferentes, Desiguales y Desconectados, de 2004, observa-se nesta presente pesquisa, uma noção de globalidade que parte de empresas estadunidenses, que desenvolvem jogos com objetivos comerciais e culturais, para um público de jogadores e fãs que possuem um pathos definido. As diretrizes destes valores e isotopias presentes em tal globalidade e em tais pathos serão discutidos em maior detalhe nos itens e capítulos posteriores. A necessidade de tal discussão se faz necessária para que a globalidade não seja aqui entendida de forma genérica, pois nas palavras do autor "Seria ingênuo pensar que tantas etiquetas com identificações asiáticas em artigos de consumo estadunidense ou em bandeiras argentinas e mexicanas atenuarão o nacionalismo destes povos, aproximando-os e facilitando sua compreensão" (CANCLINI, 2007, p. 18 - tradução nossa).
} 
Mesmo quando o universo fictício é menos mimético ao modelo sociopolítico do mundo natural, a isotopia de globalidade se mantém. O mundo fictício de $L O L$, por exemplo, é chamado de Runeterra, e a distribuição de seus campeões se dá da seguinte forma:

Figura 17 - Mapa de 2017, representando as nacionalidades das personagens dentro do universo ficcional do jogo League of Legends.

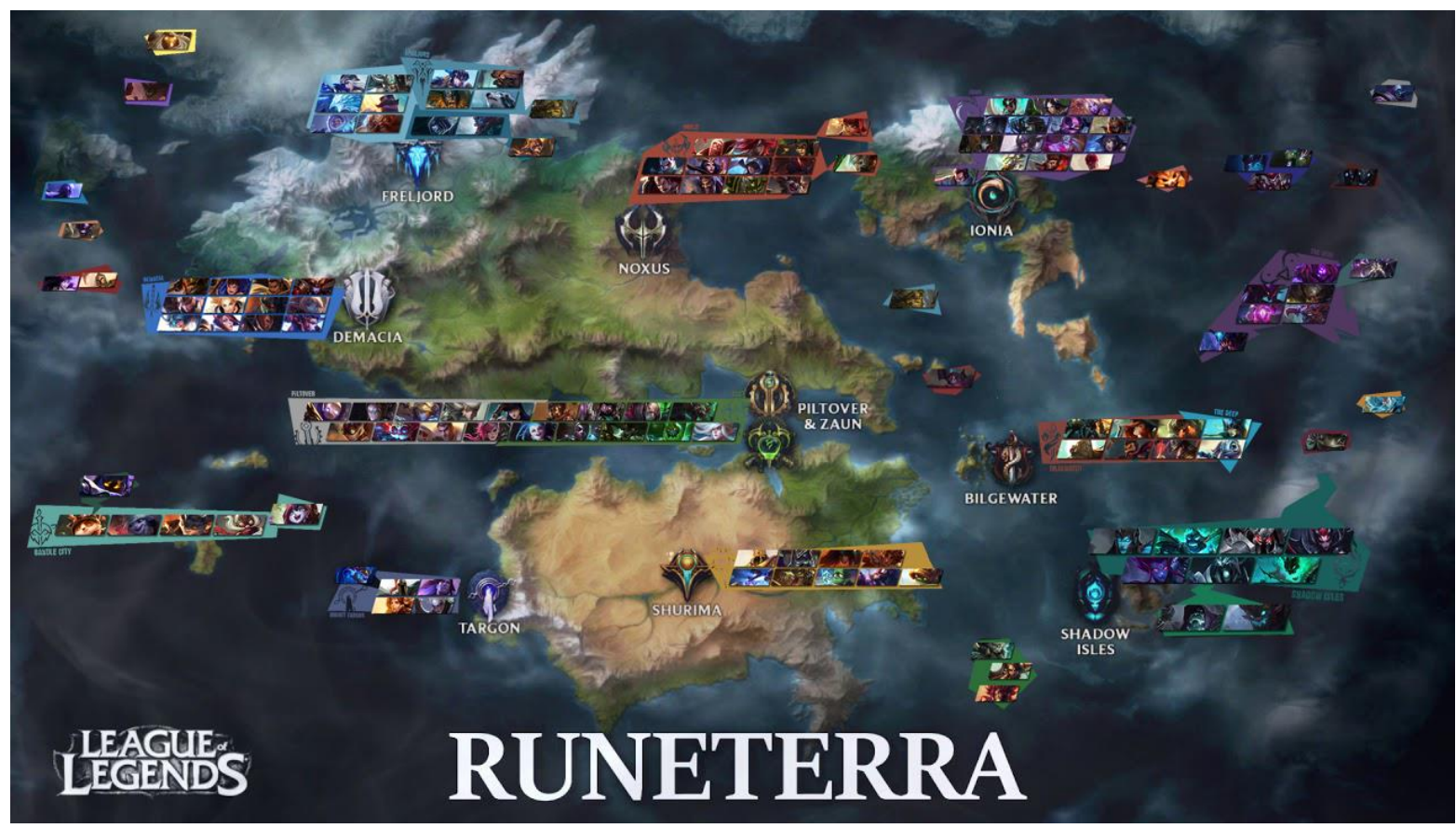

Fonte: imagem nossa, adaptada de Riot (2020).

Neste mapa, datado de fevereiro de 2017, há a seguinte distribuição de campeões entre as cidades existentes do jogo: Ionia (18 campeões), Demancia (14 campeões), Noxus (14 campeões), Freljord (14 campeões), Zaun (12 campeões), Shurima (9 campeões), Monte Targon ( 9 campeões), Blidgewater ( 8 campeões), o Vazio (8 campeões), Pitlover ( 7 campeões), Bandle City ( 7 campeões) e Shadow Islands (6 campeões), com o acréscimo de mais 21 campeões que não estavam relacionados a nenhuma cidade, sendo geralmente representantes de divindades, cidades antigas que já foram extintas, andarilhos ou mesmo membros de locais que não foram definidos dentro da mitologia do universo ficcional. Nos deteremos a seguir num desdobramento narrativo do universo de $L O L$, que faz uso destes locais não-explorados.

Em junho de 2019, foi lançada uma nova personagem em League of Legends, a campeã Qiyana, descrita como a princesa da região de Ixtal. e juntamente com a apresentação da campeã, 
foi apresentada também a região de Ixtal como uma das novas regiões de League of Legends ${ }^{49}$, sendo descrita como uma cidade com grande energia mágica, escondida dentro de uma densa selva. Após a criação de tal região, diversos campeões que já existiam em $L O L$, como Malphite (lançado em 2009), Nidalee (2009), Zyra (2012) e Rengar (2012), todos campeões com temáticas de selva, tiveram suas biografias alteradas para que fossem campeões da região de Ixtal.

Neste ítem, esta pesquisa buscou sublinhar a importância que uma isotopia de globalidade possui dentro dos jogos componentes do nosso corpus. O que está em jogo com tais isotopias, que pode justificar por exemplo o porquê de todos os campeões que foram posteriormente acampados sob o rótulo de Ixtal, possuírem características relacionadas a florestas e certos graus de selvageria, será abordado no próximo item.

\subsubsection{Das variantes: das isotopias propostas pelo elenco de personagens}

Um último ponto ao qual esta pesquisa deve lançar luz é sobre alguns fatores guiam a isotopia de globalidade apresentada em LOL e Overwatch.

Quanto às histórias de fantasias, também chamadas de contos maravilhosos ou contos de fadas por alguns, existe certa concordância entre pesquisadores da teoria literária de que elas sempre guardam paralelos com o mundo natural e os valores do leitor. Para o crítico Anatol Rosenfeld, este atributo dos textos de fantasia e ficção, surgem do que o autor chama de contextos objectuais (do alemão, Sachverhalte), que são relações atribuídas entre um objeto e suas características. Na semiótica, estes contextos objectuais são o equivalente às figuras. Nas palavras da semioticista brasileira Diana Pessoa de Barros, no livro Teoria semiótica do texto, as figuras são "um elemento da semântica discursiva que se relaciona com um elemento do mundo natural, o que cria, no discurso, o efeito de sentido ou a ilusão de realidade" (BARROS, 2005, p. 83). Ainda a respeito dos contextos objectuais, seguindo o pensamento do crítico teuto-brasileiro:

\footnotetext{
${ }^{49}$ R/LEAGUEOFLEGENDS. Ixtal: New Faction. Reddit. 08 jun. 2019. Disponível em: <https://www.reddit.com/ r/leagueoflegends/comments/bya49b/ixtal_new_faction/>. Acesso em: 09 mai. 2020.
} 
Uma das diferenças entre o texto ficcional e outros textos reside no fato de, no primeiro, as orações projetarem contextos objectuais e, através destes, seres e mundos puramente intencionais (onticamente autônomos), ou seja, a objetos determinados que independem do texto. $\mathrm{Na}$ obra de ficção, o raio da intenção detém-se nestes seres puramente intencionais, somente se referindo de um modo indireto - e isto nem em todos os casos - a qualquer tipo de realidade extraliterária (ROSENFELD, 2014, p. 17).

O semioticista Umberto Eco, em seu livro Seis passeios pelos bosques da ficção (2017), argumenta de forma similar, afirmando que um traço marcante da ficção é a sua incompletude descritiva. "Qualquer narrativa de ficção é necessária e fatalmente rápida porque, ao construir um mundo que inclui uma multiplicidade de acontecimentos e personagens, não pode dizer tudo sobre esse mundo. Alude a ele e pede ao leitor que preencha toda uma série de lacunas" (ECO, 2017, p. 9).

A repetição de um número limitado e rápido de figuras num texto também é vista como uma marca do conto de ficção pelo crítico Antônio Cândido:

Ao abordar as personagens de modo fragmentário, nada mais faz do que retomar, no plano da técnica de caracterização, a maneira fragmentária, insatisfatória, incompleta, com que elaboramos o conhecimento dos nossos semelhantes. Todavia, há uma diferença básica entre a posição e outra: na vida, a visão fragmentária é imanente à nossa própria experiência; é uma condição que não estabelecemos, mas a que nos submetemos. No romance, ela é criada, é estabelecida e racionalmente dirigida pelo escritor, que delimita (...), o conhecimento do outro. Daí a necessária simplificação, que pode consistir numa escolha de gestos, de frases, de objetos significativos, marcando a personagem para a identificação do leitor, sem com isso diminuir a impressão de complexidade e riqueza (CÂNDIDO, 2014, p. 58)

Os traços identitários aludidos por Cândido podem ser literais (como um objeto, um elemento físico) e metafóricos. Este metafórico é aqui considerado no mesmo sentido proposto por Tzvetan Todorov, em seu livro Introdução à Literatura Fantástica, onde o autor considera que "Uma metáfora isolada indica apenas uma maneira figurada de falar; mas se a metáfora é contínua, seguida, revela a intenção segura de falar também de outra coisa além do objeto primeiro do enunciado" (TODOROV, 2017, p. 70).

A semiótica greimasiana possui um termo específico para se referir ao conceito desta metáfora reiterada do qual falam Todorov e Cândido, na figura da isotopia. Segundo a semioticista Diana Pessoa de Barros, em seu livro Teoria semiótica do Texto, define o conceito de isotopia 
como "a reiteração de quaisquer unidades semânticas (repetição de temas ou recorrência de figuras) no discurso, o que assegura sua linha sintagmática e sua coerência semântica" (BARROS, 2005, p. 83). José Luiz Fiorin também concorda com esta linha de raciocínio, pois em seu livro Elementos de Análise do Discurso, o autor propõe que "Em análise do discurso, isotopia é a recorrência de um dado traço semântico ao longo de um texto. Para o leitor, a isotopia oferece um plano de leitura, determina um modo de ler o texto" (FIORIN, 2009, p. 112-113).

Portanto, a crítica literária define como características do gênero da ficção o fato de que o texto não busca representar algo com um equivalente no mundo físico, e que constrói um universo onde as representações são criadas e equilibradas pelo autor para passar certos valores. $\mathrm{Na}$ semiótica, estas características podem ser analisadas pelas figuras e pelas isotopias presentes no texto.

Ainda considerando as pesquisas de Todorov sobre os contos maravilhosos, ambos os jogos de nosso corpus se encaixam nos descritos pelo autor, porém em categorias diferentes. Overwatch pode ser definido pelo que o autor búlgaro chama de Maravilhoso Científico, onde "o sobrenatural é explicado de uma maneira racional mas a partir de leis que a ciência contemporânea não reconhece" (TODOROV, 2017, p. 63). Já LOL é o que o autor descreve como o Maravilhoso Puro, que é o "que não se explica de nenhuma maneira" (p. 63) e que se assume como um outro universo.

Ambos os jogos analisados, devido a constrições impostas pelos meios do videogame e da internet, incorrem no que Fiorin chama de pluri-isotopia. Esta construção isotópica ocorre quando:

Alguns discursos que articulam duas ou mais isotopias e outros que se desenvolvem simultaneamente sobre vários planos isotópicos. Neste último caso, não há um trecho com uma isotopia, e outro trecho com outra e a contraposição das duas, mas ocorre uma superposição de isotopias, ou seja, o discurso inteiro pode ser lido sobre mais de uma isotopia (FIORIN, 2009, p. 115). 
A primeira leitura isotópica que esta pesquisa se debruçará é o que será chamado de manifestação cultural dominante $e^{50}$. Tal matriz costuma ter muita circulação dentro da internet e do público que consome os produtos desta mídia (e tanto Overwatch quanto $L O L$ são produtos dentro desta categoria), e gera o que se costuma chamar dentro do jargão da internet de Trope.

Um trope, de acordo com a definição corrente na internet, é considerado um dispositivo ou convenção de narrativa, um atalho para descrever uma situação e que ele pode assumir que o seu público irá reconhecer ${ }^{51}$. Esta pesquisa considerará, portanto, que estes tropes representam isotopias da chamada manifestação cultural dominante.

No caso de Overwatch, como o universo do maravilhoso científico narrado visa emular um futuro alternativo para uma ontologia de mundo real, os heróis advindos de diversas partes do mundo apresentam fortes isotopias culturais, do ponto de vista da manifestação cultural dominante: Entre os personagens estadunidenses, há dois cowboys ${ }^{52}$, os dois personagens australianos são dois sobreviventes rústicos e sem noção de perigo ${ }^{53}$, a personagem indiana é uma brilhante cientista com forte indumentária e trejeitos do hinduísmo ${ }^{54}$, a personagem sul-coreana é uma gamer e possui uma série de skins de cosplay ${ }^{55}$, um dos dois personagens japoneses é um ninja, a personagem

\footnotetext{
${ }^{50}$ Para efeitos de simplificação, usaremos o termo "manifestação cultural dominante" para nos referirmos à uma leitura de mundo a partir de um viés branco, heterossexual, machista, do hemisfério norte, ocidental, colonizador e anglicano. Seguindo o princípio de pesquisa antropológico seguido por Néstor Garcia Canclini (2007), o adjetivo "cultural” será usado ao invés de "cultura" pois pode definir um estatuto de valor cultural resultantes da interação de uma cultura específica com as demais culturas. Dado que o inglês é a língua mais utilizada na internet e empresas estadunidenses possuírem grande parte do comando dos meios de produção dentro do hardware e software da rede mundial de computadores, a visão de dominância global promovida por esta manifestação cultural, e um ocasional enfrentamento e transmutação desta cultura por parte de outras manifestações culturais divergentes, ambas englobam o que esta pesquisa chamará de "manifestação cultural dominante".
}

51 TVTROPES. Tropes. Tv Tropes. Disponível em: 〈https://tvtropes.org/pmwiki/pmwiki.php/Main/Tropes>. Acesso em: 14 mai. 2020.

52 TVTROPES. Cowboy. Tv Tropes. Disponível em: <https://tvtropes.org/pmwiki/pmwiki.php/Main/Cowboy>. Acesso em: 14 mai. 2020.

53 TVTROPES. Awesome Aussie, Tv Tropes. Disponível em: <https://tvtropes.org/pmwiki/pmwiki.php/Main/ AwesomeAussie>. Acesso em: 14 mai. 2020.

54 TVTROPES. Bollywood Nerd. Tv Tropes. Disponível em: <https://tvtropes.org/pmwiki/pmwiki.php/Main/ BollywoodNerd>. Acesso em: 14 mai. 2020.

55 TVTROPES. Cosplay Otaku Girl. Tv Tropes. Disponível em: <https://tvtropes.org/pmwiki/pmwiki.php/Main/ CosplayOtakuGirl>. Acesso em: 14 mai. 2020. 
representando a Rússia é uma lutadora musculosa, patriótica e falastrona ${ }^{56}$. Isto apenas para citar alguns dos exemplos mais visíveis.

No caso de $L O L$, não existem as representações nacionais como conhecemos, porém, as nações mostradas possuem claras referências estereotípicas: Noxus é um império totalitário ${ }^{57}$, Shurima é uma região inspirada no Alto império egípcio ${ }^{58}$, Pitlover é uma região com elementos Steampunks $5^{59}$, enquanto Zaun, a cidade localizada abaixo de Pitlover, é uma distopia poluída ${ }^{60}$. Ionia, uma das regiões com mais campeões dentro do jogo, possui muitos elementos de um oriente místico ${ }^{61}$. Ainda que não exista uma correlação oficial com o mundo real, as isotopias criadas permitem tais comparações sócio-históricas ${ }^{62}$.

As personagens também possuem uma gama infinita de contextos socioculturais que contribuem para sua pluri-isotopia, como etnia, gênero, opção sexual, status social, visão ideológica entre outros. Não listaremos exemplos aqui dada a grande profusão disponível de variantes, mas analisaremos agora alguns exemplos de como estas isotopias de representatividade são consideradas importantes pela comunidade de jogadores e fãs dos jogos dos jogos do corpus desta pesquisa.

O primeiro elemento que chama a atenção é, assim como no ítem anterior, uma cobrança por parte da comunidade por uma noção de globalidade e representatividade. Pouco após o

56 TVTROPES. Husky Russkie. Tv Tropes. Disponível em: <https://tvtropes.org/pmwiki/pmwiki.php/Main/ HuskyRusskie>. Acesso em: 14 mai. 2020.

57 TVTROPES. The Empire. Tv Tropes. Disponível em: 〈https://tvtropes.org/pmwiki/pmwiki.php/Main/TheEmpire〉. Acesso em: 14 mai. 2020.

58 TVTROPES. Tv Tropes. Build Like Na Egyptian. Disponível em: <https://tvtropes.org/pmwiki/pmwiki.php/ Main/BuildLikeAnEgyptian>. Acesso em: 14 mai. 2020.

59 TVTROPES. SteamPunk. Tv Tropes. Disponível em: 〈https://tvtropes.org/pmwiki/pmwiki.php/Main/SteamPunk〉. Acesso em: 14 mai. 2020.

60 TVTROPES. Polluted Wasteland. Tv Tropes. Disponível em: <https://tvtropes.org/pmwiki/pmwiki.php/ Main/PollutedWasteland>. Acesso em: 14 mai. 2020.

61 TVTROPES. Wutai. Tv Tropes. Disponível em: <https://tvtropes.org/pmwiki/pmwiki.php/Main/Wutai>. Acesso em: 14 mai. 2020.

62 TVTROPES. Fantasy Counterpart Culture. Tv Tropes. Disponível em: <https://tvtropes.org/pmwiki/ pmwiki.php/Main/FantasyCounterpartCulture>. Acesso em: 14 mai. 2020. 
lançamento de Overwatch, em novembro de 2014, notícias e avaliações ${ }^{63}$ em sites $^{64}$ sobre jogos $^{65}$ e comentários nos fóruns chamavam a atenção para a falta de representatividade feminina no elenco de Overwatch, onde as 5 personagens femininas que existiam até então no elenco possuíam todas o mesmo biótipo curvilíneo relacionado com mulheres atraentes. Após estas críticas, dentre as 6 heroínas seguintes lançadas pela Blizzard para o jogo, 4 não pertenciam a tal estereótipo: uma mulher robusta e musculosa (Zarya, lançada em março de 2015), uma mulher acima do peso (Mei, lançada em novembro de 2015), uma mulher idosa (Ana, lançada em Julho de 2016) e uma robô construída por uma menina de 11 anos (Orisa, lançada em Março de 2017) ${ }^{66}$.

Periodicamente, tanto em Overwatch quanto também em $L O L$, alguma nova polêmica toma conta dos espaços de discussão de fãs e jogadores, seja a ausência de mulheres negras como heroínas de Overwatch $^{67}$, ou a revelação de que o Soldado 76, personagem que incorporava valores dos ídolos militaristas de filmes de ação estadunidenses, é homossexual ${ }^{68}$. De modo geral, a maior parte destas polêmicas gira em torno dos valores que compõem cada personagem do elenco disponível, em comparação com o mundo natural. Este embate costuma ocorrer segundo a lógica de construção cultural proposta por Canclini, entre os valores de uma manifestação cultural dominante e suas forças opositoras e modificadoras.

${ }^{63}$ GEIER, Caitlin. The Disappointing Lack of Female Body Diversity in Overwatch. Caitlin Geier. 10 mai. 2019. Disponível em: <http://www.caitlingeier.com/the-disappointing-lack-of-female-body-diversity-in-Overwatch/>. Acesso em: 15 mai. 2020.

${ }^{64}$ LIN. Diversity and Representation In Overwatch Part 1. The Fandomentals. 18 ago. 2017. Disponível em: <https://www.thefandomentals.com/diversity-representation-Overwatch/>. Acesso em: 15 mai. 2020.

65 ARTHUR, Ayla. On Designing Women in Games. Medium. 10 nov. 2014. Disponível em: <https://medium.com/ @FourArmsDemon/on-designing-better-women-in-games-ebe785d8689/>. Acesso em: 15 mai. 2020.

${ }^{66}$ OVERWATCH WIKI. Heroes. Gamepedia. Disponível em: <https://Overwatch.gamepedia.com/Heroes>. Acesso em: 15 mai. 2020.

67 MELLOR, Imogen. Why Overwatch 2's Sojourn isn't enough. PCGamesn. 11 nov. 2019. Disponível em: <https://www.pcgamesn.com/Overwatch-2/sojourn-diversity>. Acesso em: 15 mai. 2020.

68 TASSI, Paul. Yes, 'Overwatch’ Making Both Soldier: 76 And Tracer Gay Is A Big Deal. Forbes. 08 jan. 2019. Disponível em: <https://www.forbes.com/sites/insertcoin/2019/01/08/yes-Overwatch-making-both-soldier-76-andtracer-gay-is-a-big-deal/\#6d520e887008>. Acesso em: 15 mai. 2020. 
Adicionando mais temas e valores dentro da pluri-isotopia que compõe este elenco de personagens de LOL e Overwatch, há ainda e existência dentro do jogo das skins e dos Easter Eggs.

Skins são recursos disponíveis tanto em Overwatch quanto em $L O L$ que alteram a aparência do campeão/herói utilizado. No caso dos jogos do corpus analisado, as skins não alteram nenhum atributo do campeão/herói, muito menos as possibilidades de manipulação da personagem pelo jogador ou interação com o cenário, sendo recursos cosméticos. Dentro da metalinguagem da semiótica, o uso de skins pode ser interpretado como uma mudança no nível discursivo do texto, o actante sujeito continua operando normalmente dentro do nível narrativo, porém as figuras e as consequentes isotopias que são evocadas no nível discursivo podem ser identificadas se modificam.

Vejamos alguns exemplos da aplicação de skins em $L O L$, dos personagens Gragas e Riven:

Figura 18 - Algumas skins disponíveis para o campeão Gragas. 

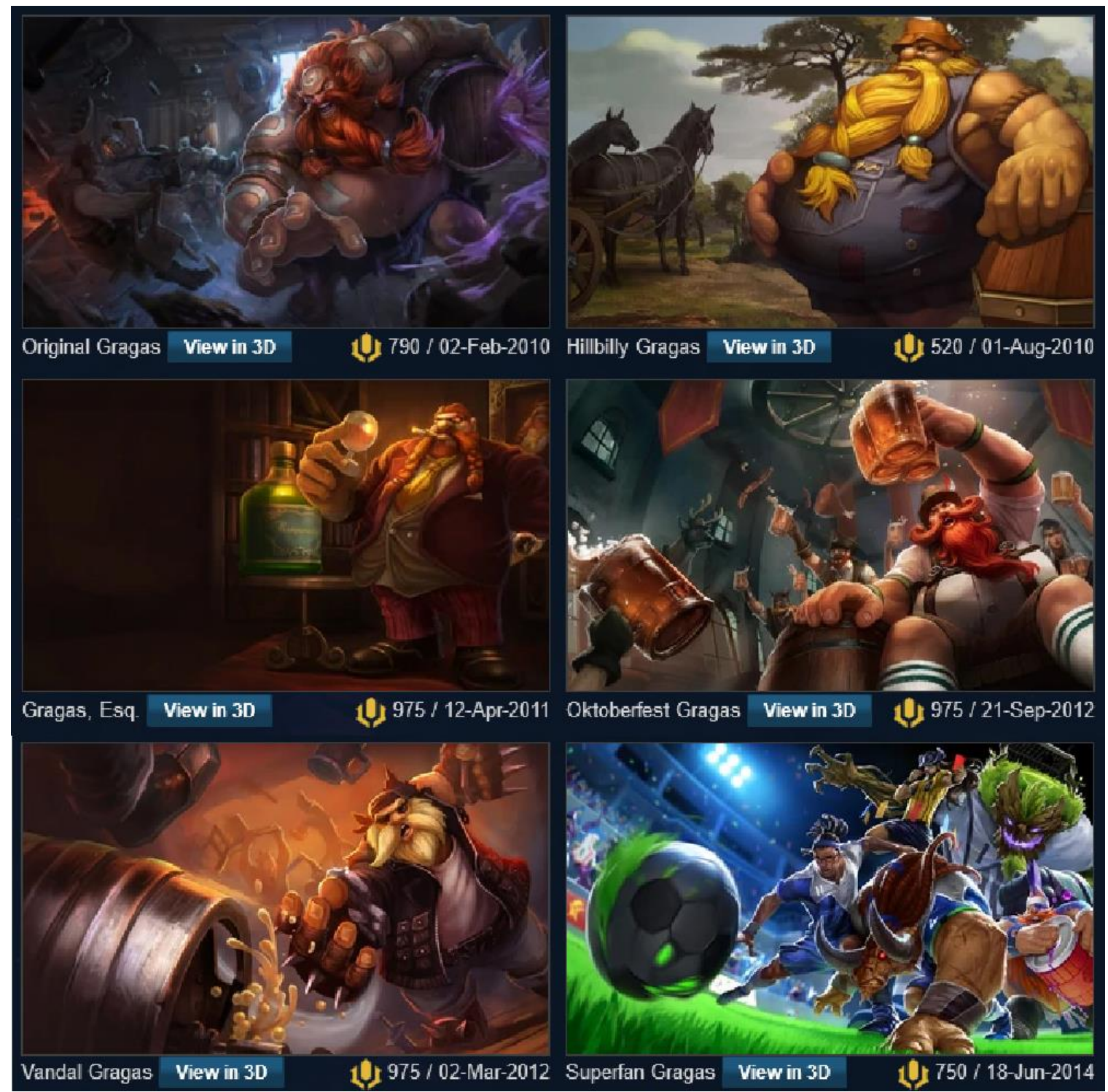

Vandal Gragas View in 3D

1) $975 / 02-M a r-2012$

View in 3D

Fonte: Riot $(2020)^{69}$.

Figura 19 - Algumas skins disponíveis para a campeã Riven.

${ }^{69}$ Disponível em: <https://leagueoflegends.fandom.com/wiki>. Acesso em: 09 mar. 2021. 


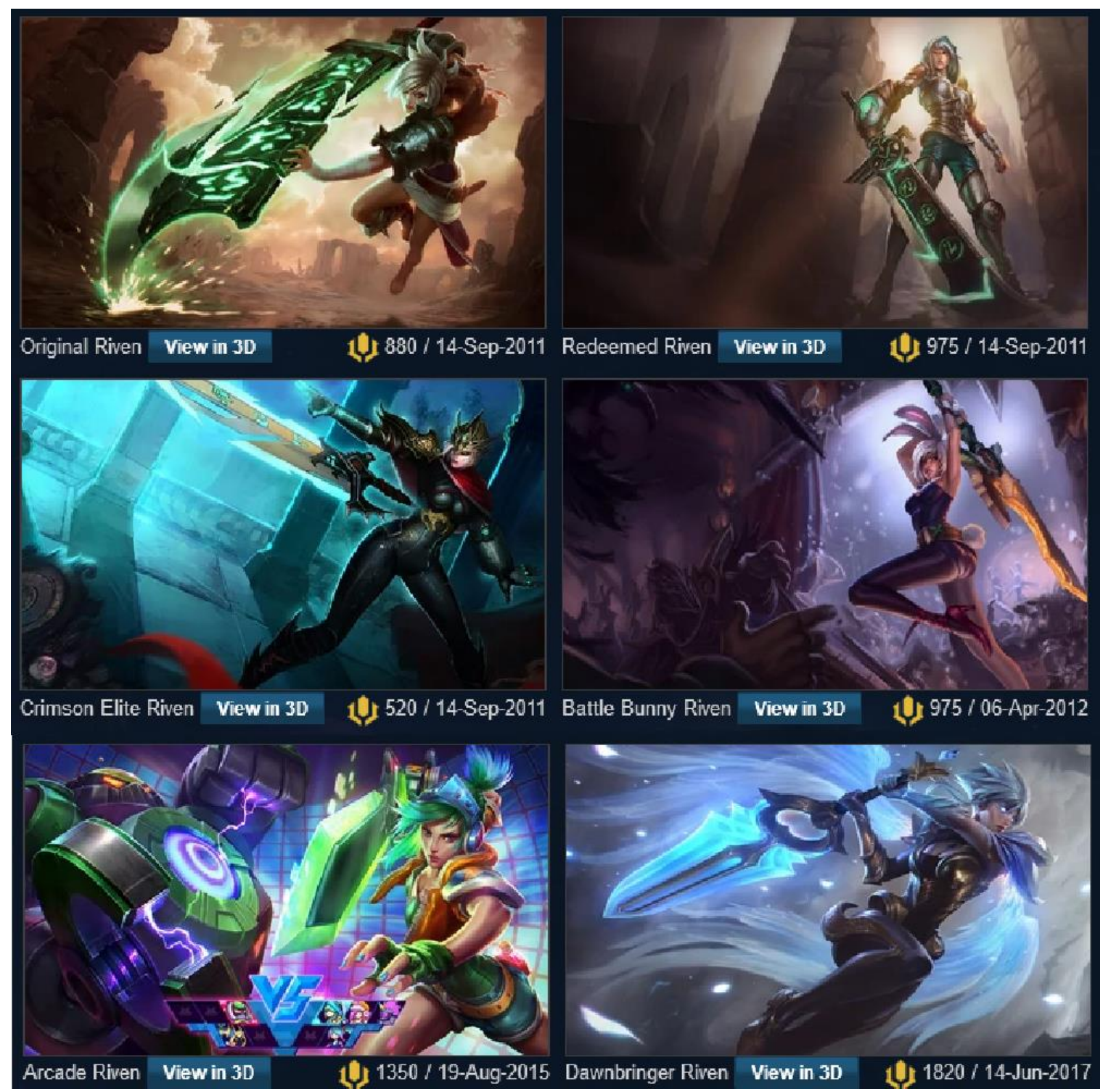

Fonte: Riot $(2020)^{70}$.

As skins disponíveis nos jogos de nosso corpus geralmente podem ser adquiridas das seguintes formas:

- $\quad$ podem ser compradas com o dinheiro fictício que o jogador ganha a cada partida, e que serve para a aquisição de melhorias dentro do universo do jogo;

\footnotetext{
${ }^{70}$ Disponível em: <https://leagueoflegends.fandom.com/wiki>. Acesso em: 09 mar. 2021.
} 
- $\quad$ podem ser conquistadas após o cumprimento de certas conquistas, como um número de vitórias ou um avanço dentro das divisões hierárquicas do jogo;

- $\quad$ podem ser ganhas aleatoriamente como recompensa após cada partida realizada pelos jogadores ou;

- $\quad$ podem ser dadas como presente aos jogadores durante promoções ou datas comemorativas, dentro da interface do site do jogo.

Sendo amplamente usadas por jogadores nas partidas e sendo representadas nas fanarts produzidas pelos jogadores e fãs, as skins podem ser agrupadas em algumas categorias gerais. Notese que as categorias descritas abaixo são uma escolha desta pesquisa para a explanação, não refletindo nenhum sistema oficial:

- Skins de prestígio. Geralmente nomeadas com nomes de minerais (ouro, platina, diamante etc.) ou títulos (elite, especial etc.), costumam denotar figuras de luxo e poder, como por exemplo as skins da campeã Riven chamadas "Dawnbringer" e "Crimson Elite" e apresentadas acima;

- $\quad$ Skins da narrativa. São skins que apresentam versões campeões/heróis em momentos anteriores ou posteriores do ponto fixo na história do universo ficcional onde os combates do jogo se passam. Overwatch, por possuir uma narrativa cronologicamente mais organizada, costuma se valer mais desta modalidade, especialmente mostrando skins de heróis em momentos passados. A skin da campeã Riven apresentada acima, chamada "Redeemed" (do inglês redimida) é um exemplo. A skin mostra a espada da campeã reconstruída, e não aos pedaços, como em sua skin "original". A espada quebrada (por ela mesma) simboliza o arrependimento da personagem por suas ações passadas em nome do Império de Noxus, portanto a reconstrução da espada, além do termo "redimida", representa a conjunção dela com seu objeto de valor do perdão por seus atos. Note-se que estas skins não contradizem o que foi abordado por esta pesquisa num item anterior, onde postulou-se sobre a ausência de sanção da narrativa das personagens. É comum também existirem skins "corrompidas", representando uma narrativa disfórica, quando a personagem falha em entrar em conjunção com seu 
objeto de valor. O campeão Ryze, por exemplo, possui uma skin chamada "Young", que o apresenta no começo de sua jornada, e também duas skins que expõe os desfechos eufórico e disfórico de seu percurso, a "Triumphant" (que representa sua conjunção com o objeto de valor de domínio e compreensão dos cristais mágicos que busca) e a "Dark Cristal" (que representa sua narrativa disfórica de ser consumido pelo poder dos cristais, tal qual seu antigo mestre). Portanto, tais skins não representam uma sanção na narrativa do campeão, apenas uma referência cosmética às possibilidades de sanção que tal narrativa possui, podendo ser acumuladas dentro das opções cosméticas do uso do campeão, sem com isso interferir em sua sanção narrativa no jogo.

Figura 20 - Algumas skins disponíveis para o campeão Ryze.

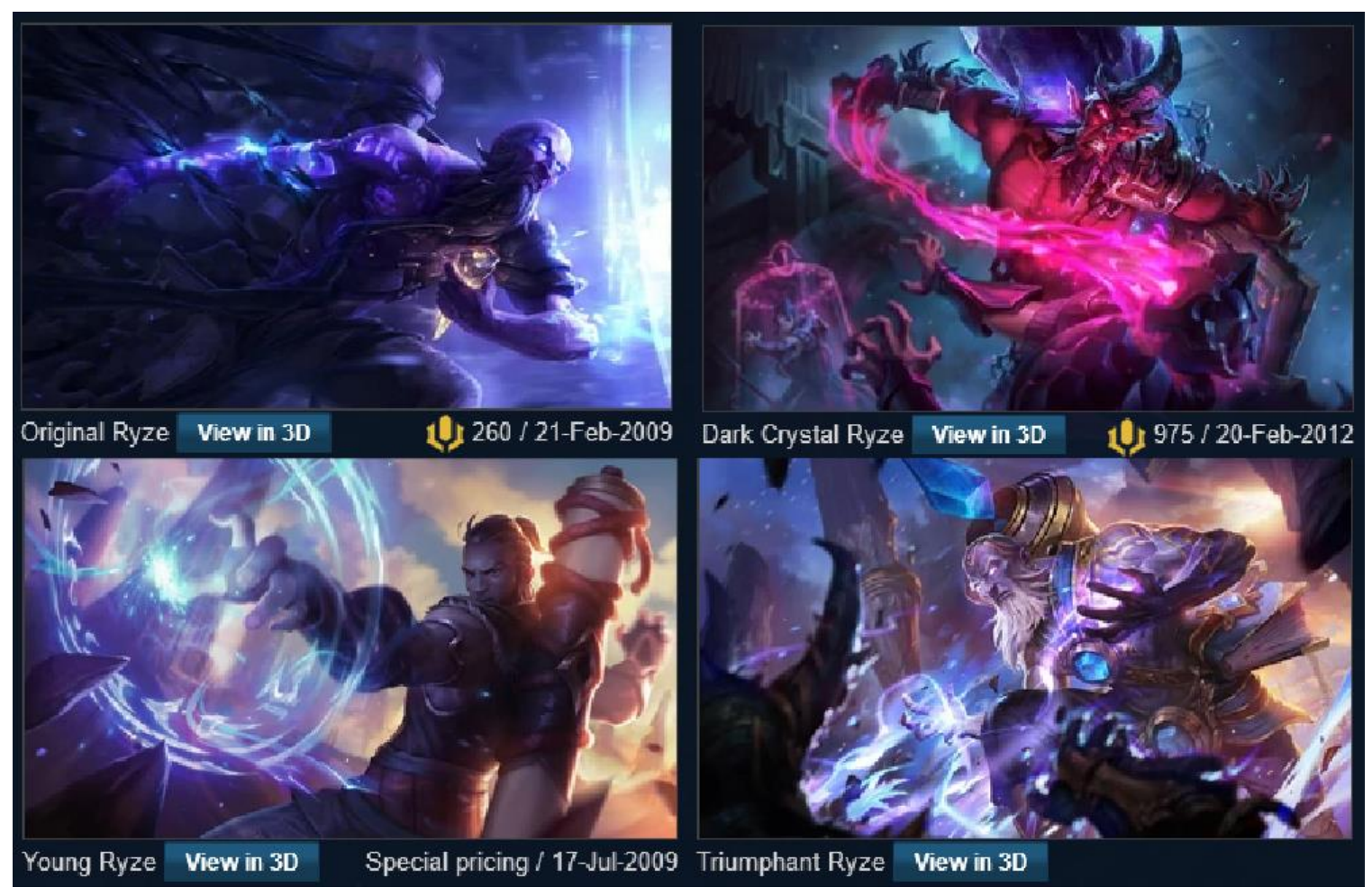

Fonte: Riot $(2020)^{71}$.

\footnotetext{
${ }^{71}$ Disponível em < https://leagueoflegends.fandom.com/wiki>. Acesso em 09 de mar. 2020.
} 
- Skins comemorativas. Geralmente são skins ofertadas ou disponíveis apenas nos períodos de festas, como por exemplo natal, páscoa, Dia de Ação de Graças etc. A skin do campeão Gragas “Oktoberfest”, apresentada acima, é um exemplo.

- $\quad$ Skins de fantasia. São skins consideradas como fantasias (no sentido do vestuário) cômicas, que não costumam sequer possuir relação com o universo do jogo, se referindo diretamente a figuras do mundo natural. Dentre os exemplos acima, temos as skins "Hillybilly" e "Vandal" de Gragas (que representam um caipira do sul estadunidense e um motoqueiro nos moldes do Hell's Angels respectivamente) e as skins "Arcade" e "Battle Bunny" de Riven (que representam uma personagem de videogames infantis e uma coelhinha da revista playboy, respectivamente).

- $\quad$ Skins de grupo. São skins que podem se encaixar em qualquer uma das categorias acima, porém sendo uma identidade visual para um grupo de campeões, fazendo parte de uma série e permitindo, por exemplo, que um time de jogadores entre em uma partida "uniformizado". A skin do campeão Gragas "Superfan", apresentada acima, é um exemplo, pois Gragas divide esta skin com temática futebolística com os campeões Malachite, Twisted Fate, Lucian e Alistair.

Estes conjuntos de skins, podendo ser utilizados na maioria das partidas tanto em $L O L$ quanto em Overwatch, se inserem nas simbologias presentes no jogo, criando figuras e isotopias, de certa forma autorizadas pelo enunciador do jogo, na figura dos desenvolvedores. De maneira similar, o aumento das pluri-isotopias é também a consequência do uso dos Easter Eggs.

O termo Easter Eggs foi cunhado por Steve Wright, diretor de software da Atari, a respeito de uma mensagem deixada pelo programador Warren Robinett em uma posição específica no mapa do jogo Adventure (1979) ${ }^{72}$. O termo em inglês se refere aos ovos de páscoa, e a tradição de escondê-los para que as crianças os procurem durante o domingo pascoal. Os Easter Eggs são, portanto, mensagens dos mais variados tipos, como textos, imagens, áudios etc., deixadas dentro

\footnotetext{
72 WIKIPEDIA. Easter Egg (media). Wikipedia. Disponível em: 〈https://en.wikipedia.org/wiki/Easter_egg_(media)>.
} Acesso em 19 mai. 2020. 
do ambiente do jogo, geralmente endereçadas à cognição do jogador, e não à personagem presente no universo do jogo.

Os Easter Eggs em LOL podem ser homenagens a elementos antigos do jogo que foram retirados em builds mais recentes ${ }^{73}$. Podem ser também mudanças na interface do jogo, como o caso campeão Anívia, uma espécie de fênix de gelo, que tem seu nome no chat da partida modificado para Eggnivia $($ Egg = Ovo em inglês - Egg + Anivia $)$ quando sua habilidade de renascer de um ovo, isotopia da fênix, está ativada ${ }^{74}$.

Porém em Overwatch os Easter Eggs são utilizados com muito mais intensidade e profusão. Podem ser referência a outros textos de outras empresas de outros universos ficcionais. Como por exemplo quando o herói Winston, um gorila geneticamente modificado, pode dizer "é melhor não me deixar nervoso" durante uma luta, frase clássica relacionada ao personagem Hulk, da Marvel, pois tanto Winston quanto Hulk possuem a habilidade de mudar de cor e aumentar em muito a própria força quando estão irritados. Outro exemplo é a fala que o personagem McCree, um caubói, pode dizer durante um combate: "Não sou o bom, nem o mau, mas certamente não sou o feio", numa referência ao famoso filme de Spaguetti western chamado O bom, o Mau e o Feio (The good, the bad and the ugly - 1966) de Sérgio Leone ${ }^{75}$.

Outro exemplo do uso de Easter Eggs, desta vez com fins publicitários, é o fato de que em todos os cenários do jogo, existem tablets espalhados pelo cenário, e estes tablets estão sempre

73 CHANA DEL REY. Easter Eggs do nosso Lolzinho \#1. Riot Games. 31 mar. 2018. Disponível em: $<$ https://forums.comunidades.riotgames.com/t5/Outros-Assuntos-de-LOL/Easter-Eggs-do-nosso-LOLzinho-1/tdp/177232>. Acesso em: 19 mai. 2020.

74 LEAGUE OF LEGENDS WIKI. Easter Egg. Fandom. Disponível em: <https://leagueoflegends.fandom. com/wiki/Easter_egg>. Acesso em: 19 mai. 2020.

75 Note-se que o filme foi lançado no Brasil como Três homens em conflito, em 1968, e que a piada é uma tradução direta ao nome do filme em inglês. Porém, como dito anteriormente, os Easter Eggs são feitos para a diversão e modalização dos jogadores, portanto seu não-conhecimento ou não-compreensão não alteram diretamente a experiência lúdica. 
exibindo a tela de duelo de Hearthstone, um jogo digital de cartas produzido pela Blizzard, que é a produtora de Overwatch ${ }^{76}$.

Os Easter Eggs podem ainda revelar segredos, ou comprovar teorias que circundam o universo fictício de Overwatch e suas atualizações, geralmente aguardadas pelos fãs. Um exemplo que ficou famoso foi o do lançamento da personagem Sombra, em novembro de 2016. A partir de julho daquele mesmo ano, diversos Easter Eggs na forma de códigos e imagens foram espalhados nos cenários do jogo, bem como nos materiais promocionais. Estes Easter Eggs davam dicas e apresentavam senhas para que os fãs descobrissem informações sobre a nova heroína ${ }^{77}$ (uma hacker) antes de seu lançamento em novembro ${ }^{78}$.

Longe de analisar cada tipo de Easter Egg, ou cada dinâmica na construção de skins, esta pesquisa se limita a levantar a existência e recorrência destes dois elementos dentro do universo do jogo. Do ponto de vista semiótico, tanto o Easter Egg quanto a skin se encontram em níveis distintos de organização textual em relação ao texto do jogo.

No artigo intitulado "a noção de texto e os níveis de pertinência da análise semiótica" (2018) de Matheus Schwartzmann, o autor fala sobre a configuração do texto, e sobre o "reconhecimento de níveis de complexidade, de aspectos distintos e complementares do processo de constituição da significação e - portanto, da constituição do texto" (SCHWARTZMANN, 2018, p. 3). Os referênciais dos Easter Eggs e das skins estão presentes dentro do processo cognitivo do jogo, mas não em seu nível de texto, ou suporte; portanto não nos deteremos em sua análise, mas compreenderemos que ambos colaboram para o adensamento figurativo e o processo de pluri-

\footnotetext{
${ }^{76}$ GOMES, Sara. Descubra todos os easter eggs e referências de Overwatch. Aficionados. 01 ago. 2017. Disponível em: <https://www.aficionados.com.br/easter-eggs-Overwatch/>. Acesso em: 19 mai. 2020.

${ }^{77}$ Esta dinâmica entre os fãs/jogadores e os desenvolvedores de Overwatch, onde ocorre um jogo de investigação paralelo ao jogo em si, é uma estratégia de marketing comum em produtos transmídia, recebendo o nome de ARG (Alternate Reality Game), e estudado por pesquisadores como Henry Jenkins (2009) e Eddie Duggan (2017). Esta pesquisa não pretende se aprofundar sobre tais mecânicas.
}

78 GAME DETECTIVES WIKI. Sombra ARG. MediaWiki. Disponível em: <https://wiki.gamedetectives.net/ index.php?title=Sombra_ARG>. Acesso em: 19 mai. 2020. 
isotopia, criando relações que se complementam ou mesmo se contradizem, algo que será abordado em detalhe no próximo capítulo.

Agora portanto, cabe estruturar, dentro do modelo de análise semiótica desenvolvido por Cardozo Angelo, como se apresentam as observações levantadas até o momento.

\subsection{Análise de LOL e Overwatch dentro do modelo de análise semiótica de Angelo}

Ao aplicar as observações apontadas nos itens anteriores dentro do modelo proposto por Cardoso Angelo, descrito no capítulo anterior, referente ao jogo Overwatch, apresenta-se o seguinte resultado:

Figura 21 - Modelo de análise semiótica do jogo Overwatch. 


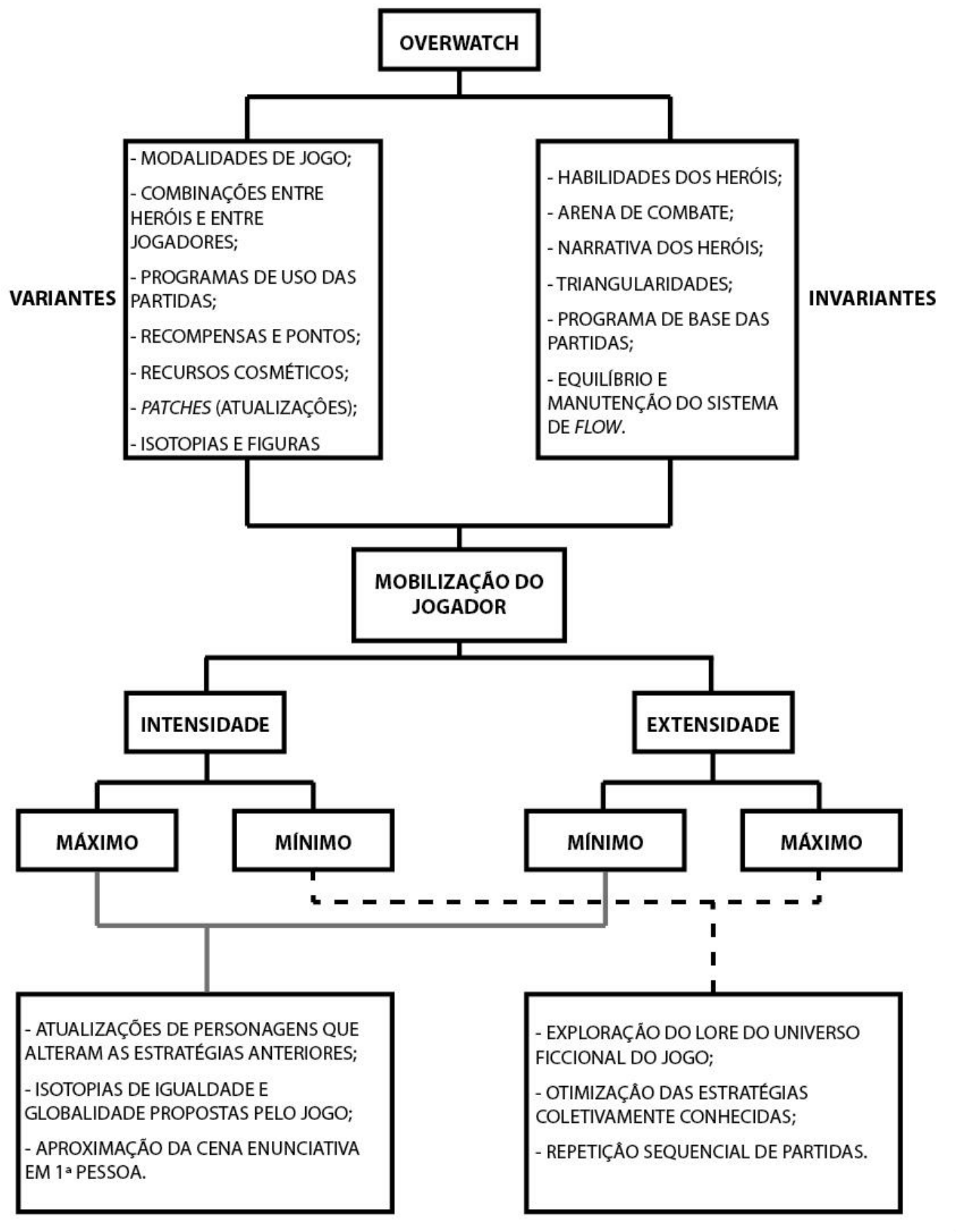

Fonte: imagem nossa, adaptada de Angelo (2015).

Pela análise do modelo acima apresentado, algumas questões abordadas nos itens anteriores ficam localizadas. O programa de base da vitória é uma invariante, enquanto os programas de uso 
para modalizar tal vitória são uma variante, responsável por grande parte das habilidades que o jogador deve demonstrar, usando combinações entre tipos de heróis e tipos de jogadores.

As regras do jogo, que compõe a maior parte das variantes do jogo, são as arenas de combate, cuja previsibilidade pode ser usada a favor dos jogadores, bem como o conhecimento das habilidades de cada herói, regidas pelo princípio da triangularidade. Um dos princípios que regem o jogo, a dinâmica do Flow, possui um funcionamento particular: se compõe das invariantes do conhecimento dos mapas e do elenco de heróis com as variantes introduzidas a cada novo patch de atualização.

Para a mobilização do jogador, a análise acima apresenta a consequência do regime do Flow, pois promove um movimento de (alta intensidade baixa extensidade) nas partidas onde os jogadores precisam enfrentar novas combinações de habilidades e estratégias, promovidas pelos Patchs, e promove um movimento de tédio (alta extensidade e baixa intensidade) quando o jogador, já conhecedor das lógicas implicativas do elenco de heróis, busca otimizar as estratégias coletivamente conhecidas através da repetição sequencial de partidas.

Abaixo, segue o modelo aplicado ao jogo LOL:

Figura 22 - Modelo de análise semiótica do jogo League of Legends. 


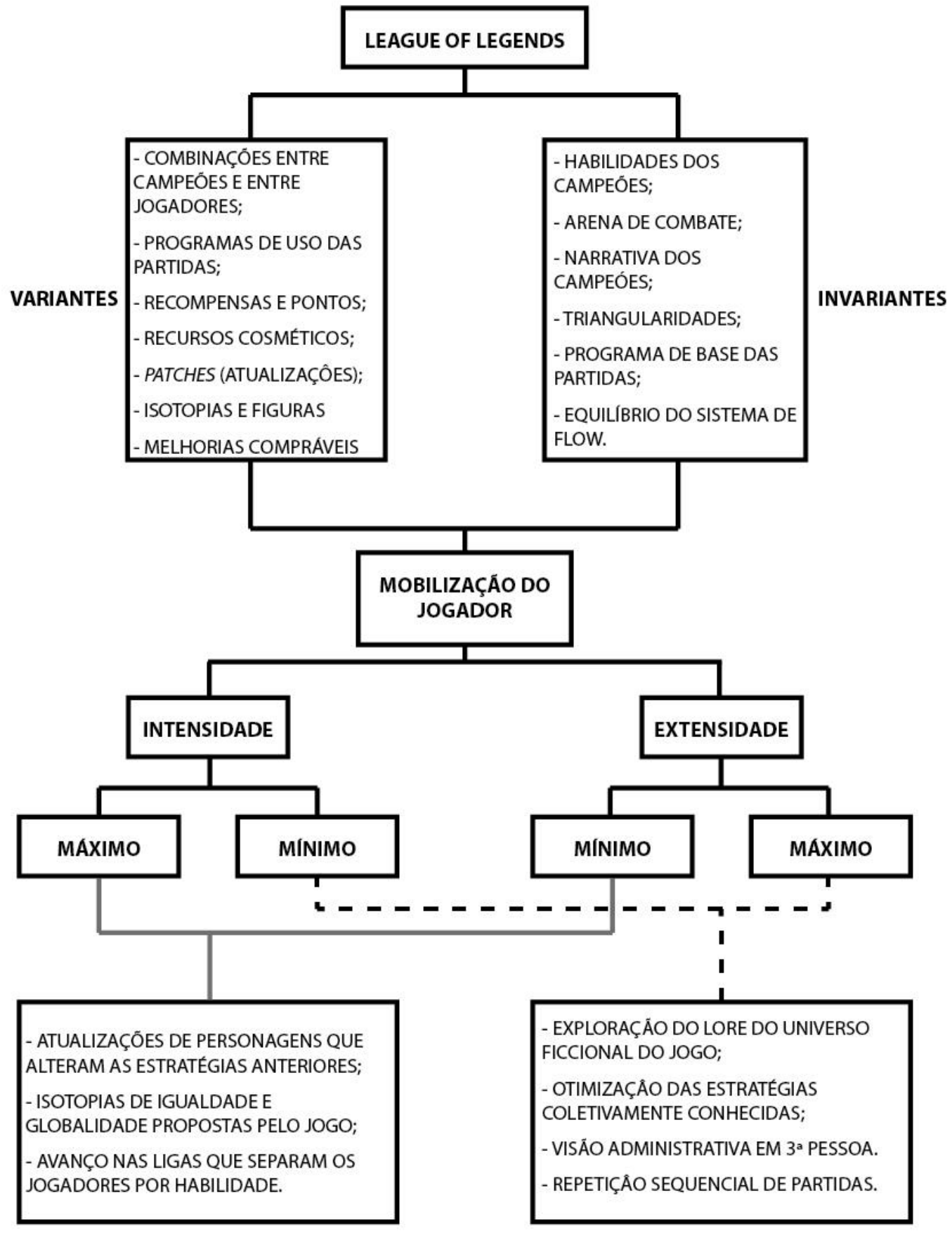

Fonte: imagem nossa, adaptada de Angelo (2015).

Existem algumas similaridades entre as conclusões apresentadas no modelo de $L O L$ em relação ao modelo de Overwatch. Entre as principais diferenças estão a possibilidade de que alguns 
poderes que serão utilizados pelos campeões sejam compráveis em uma loja durante a partida, adicionando uma nova variável à estratégia do jogador.

Outra diferença importante é que, enquanto a câmera em $1^{a}$ pessoa de Overwatch promove uma maior intensidade e uma menor extensidade, pois aproxima o jogador da cena enunciativa, em $L O L$, a câmera em $3^{\mathrm{a}}$ pessoa faz o contrário, pois fornece ao jogador uma visão mais distanciada.

Em ambos os casos, a questão da narrativa se mostra categorizada de maneira similar. Ambos os jogos possuem um grupo de informações biográficas de seus elencos de personagens fictícios, e tais informações são invariáveis. Já as isotopias e figuras podem variar, pois necessitam da interação dos jogadores e fãs para serem estabelecidas. Enquanto a exploração de tais pluriisotopias possam ser feitas em momentos de alta extensidade e baixa intensidade na experiência do jogador. A cada novo patch, onde novas skins e personagens podem ser adicionados, aumenta-se a intensidade, pois as novas adições alteram as isotopias de igualdade e globalidade propostas, bem como reorganizam as figuras e isotopias existentes.

Quanto à experiência do jogador no jogo em si, sua experiência narrativa e sua sanção performativa se mostram adequadamente observadas neste capítulo. Porém, as questões envolvendo a ausência de sanção das personagens utilizadas, bem como a manutenção de figuras e isotopias do nível discursivo ainda apresentam questões para serem observadas. No próximo capítulo, será abordada a construção e utilização de tal universo fantasioso por parte dos jogadores e fãs, que ocorre não na atividade do jogo em si, mas sim no espaço de fórum. 


\section{OBJETO DOIS: OS FÓRUNS}

\subsection{Metodologia da análise discursiva dos fóruns}

O ambiente digital, dada sua multiplicidade midiática e particularidades técnicas, se apresenta sempre como um objeto desafiador para os estudos da semiótica. Nos últimos anos, um número cada vez maior de pesquisadores tem se debruçado sobre tal objeto, tentando analisar como nele é produzida a enunciação, bem como quais são as limitações e constrições promovidas durante tal prática comunicacional. A presente pesquisa, almejando contribuir com mais um tijolo em tal empresa, irá primeiramente estabelecer uma metodologia de análise, a partir de modelos desenvolvidos nos últimos anos.

Um destes modelos, de onde essa pesquisa partirá para a definição das propriedades de seu objeto, é a análise do artigo "Gêneros textuais emergentes no contexto da tecnologia digital”, em que Luiz Antônio Marcuschi propõe um levantamento de tipos de ambientes digitais, onde, segundo o autor, nasceriam os futuros "gêneros textuais da internet". Os fóruns que serão abordados nesta pesquisa inicialmente se enquadram na categoria que o autor chama de Lista de Discussão, caracterizada em seu artigo como um "grupo de pessoas com interesses específicos, que se comunicam em geral de forma assíncrona, mediada por um responsável que organiza as mensagens e eventualmente faz triagens" (MARCUSCHI, 2009, p. 34).

O autor lista como elementos destacáveis do modelo de lista de discussão, além da assincronia na comunicação, a presença de moderadores, que observam as interações entre os participantes, já que "há, pois, tanto um código de ética como um conjunto de valores que censuram a operacionalidade destas listas" (MARCUSCHI, 2009, p. 69), e também uma tendência em coibir mensagens que não tratem dos conteúdos que originaram o próprio fórum (no caso desta pesquisa, os jogos). No próximo capítulo, será mostrado que, no caso deste corpus analisado, o conceito destes "assuntos paralelos" é mais ambíguo do que parece.

Sobre as características definidoras destes espaços digitais, o próprio Marcuschi admite que “o grande risco que corremos ao definir e identificar esses gêneros situa-se na própria natureza da tecnologia que os abriga. Seu vertiginoso avanço pode invalidar com grande rapidez as ideias aqui 
expostas, o que nos obriga a ter muita cautela" (MARCUSCHI, 2009, p. 30). Esta pesquisa concorda com o autor, pois os fóruns e sites que compõe o corpus não se encaixam de modo preciso na modalidade de lista de discussão, trazendo alguns elementos de outras modalidades descritas por Marcuschi e que valem a pena ser observadas.

Os fóruns Reddit e Danbooru, por exemplo, permitem que se abram conversas privadas entre dois perfis, além da interação principal e pública nos fóruns. Esta modalidade é similar aos chats em salas privadas, descritos no artigo de Marcuschi como "uma interação a dois sem a possibilidade de acessar mais ninguém. Isso traz a diminuição sensível de emoticons e em geral diminui as tensões" (MARCUSCHI, 2009, p. 60). Outro elemento dos fóruns que pode ser encontrado no trabalho de Marcuschi é o anonimato, onde os frequentadores interagem através de apelidos, característico dos modelos de Chat em sala aberta, também observados pelo autor.

Vale notar também que, na busca por um gênero de escrita digital, Marcuschi postula que, ainda que não se possa defini-lo com clareza, algumas características comuns aos vários espaços de interação digital podem ser observadas: "Uma destas estratégias é a produção de enunciados mais curtos e com menor índice de nominalizações por frase” (MARCUSCHI, 2009, p. 76).

Após uma definição das principais características dos espaços interativos a serem analisados, neste caso os fóruns digitais, deve-se agora abordar o recorte de texto que será analisado. Porém, deve-se para isso expor os motivos que levam esta pesquisa a fazer uma análise dos jogos de $L O L$ e Overwatch para, então, analisar seus respectivos fóruns.

Como apresentado no capítulo anterior, as isotopias e figuras, criadas e manipuladas para a definição de sentido sobre o universo de valores do jogo, é resultante de um processo multimídia, ou ainda transmídia, segundo as análises de Jenkins (2008). Tais isotopias e valores que regem a imersão do jogador em tal universo de sentido são resultantes de muitas variáveis: de similaridades das mecânicas de LOL e Overwatch com outros jogos de diversos gêneros (o uso de arquétipos como "tanque", "assassino" e "suporte"), de isotopias e figuras evocadas do mundo das coisas (a temática de Cowboy da personagem McCree, de Overwatch, ou a Temática Steampunk da personagem Caitlyn, de $L O L$ ), além de outras figuras e isotopias emprestadas de tropes advindos 
de uma manifestação cultural dominante da internet (Como a referência, em $L O L$, a uma terra mística com traços orientais na apresentação de Ionia $^{79}$ ).

No ambiente de fórum - onde todos os leitores podem comentar cada post e cada texto apresentado, inclusive anexando imagens ou hiperlinks para outras páginas - a complexidade de tal comunicação e a manipulação de tais isotopias e figuras tendem a se multiplicar exponencialmente. Para poder entender as estratégias de manipulação da veridicção, esta pesquisa crê ser necessário que se possa observar os princípios ideológicos mais homogêneos que regem as interações no fórum, bem como organizam as figuras, temas e isotopias.

Em seu livro Teoria do discurso: Fundamentos Semióticos (1988), Pessoa de Barros aponta que, enquanto necessária, a análise imanente não é capaz de acessar o “enunciador sócio-histórico”, o manipulador dos valores inseridos na figura do enunciador do discurso. Para acessar tais valores, a autora propõe:

Refazer os caminhos narrativos do destinador-manipulador e do destinadorjulgador, assim como os percursos temáticos de produtor e receptor-interpretante, pelo recurso aos textos que formam o contexto do discurso em questão. Revê-se o problema do contexto em termos de relações intertextuais. Assim entendido, o contexto não se confunde com o "mundo das coisas". É antes considerado como um texto maior, uma totalidade de significação, no interior do qual cada texto cobra sentido. (BARROS, 1988, p. 142)

Ainda que tal contexto seja sempre uma empreitada perigosa, pois desde Greimas é alertado que "fora do texto não há salvação", Pessoa de Barros delimita bem o escopo de tal "contexto":

Não se tem a pretensão de reconstruir o macrotexto cultural, mas se julga imprescindível, para a análise semiótica de um texto qualquer, a determinação de suas interações contextuais. Recorta-se, dessa forma, a totalidade do textocontexto, graças às suas relações com o texto em exame. (BARROS, 1988, p. 142)

Pessoa de Barros define ainda três categorias de contextos que devem ser levados em consideração no estudo de um texto:

79 TVTROPES. Wutai. Tv Tropes. Disponível em: <https://tvtropes.org/pmwiki/pmwiki.php/Main/Wutai>. Último acesso: 20 out. 2020. 
- Contexto situacional: é o contexto de caráter metalinguístico, definido por ser um texto que situa o sujeito da enunciação, como os objetivos da fabricação do texto, ou suas intenções, como cartas do autor, análises da obra, comentários etc. Umberto Eco, em Seis passeios pelos bosques da ficção (2017), retomando a terminologia de Genette (2010), chama tais contextos situacionais de paratexto, que "consiste em toda a série de mensagens que acompanham e ajudam a explicar determinado texto mensagens assim como anúncios, sobrecapa, título, subtítulos, introdução, resenhas, e assim por diante" (ECO, 2017, p. 150);

- Contexto interno: é o contexto de caráter idioletal $^{80}$, determina os elementos ideológicos e linguísticos que caracterizam o produtor e o sujeito da enunciação. É o que define o estilo de Guimarães Rosa e seus neologismos linguísticos, por exemplo;

- Contexto externo: é o contexto de caráter socioletal ${ }^{81}$, os valores que produtor e receptor manipulam, sejam eles de classe, de grupo, de época ou de cultura. São as características que definem o estilo em comum de escritores e obras categorizadas como "Naturalismo brasileiro do final do século XIX", por exemplo.

Para a definição adequada de quais serão estes textos-contextos, aqui será retomado um dos princípios norteadores desta pesquisa, que foi apresentado na introdução: os objetivos aqui buscados não são o da criação um sistema fechado e cristalizado para a interpretação do uso da veridicção nestes ambientes, mas sim o levantamento de algumas estratégias usadas pelos enunciadores para o sancionamento veridictório dentro do ambiente de discussão sobre jogos digitais.

\footnotetext{
${ }^{80}$ Idioleto é um conjunto de normas individuais que caracteriza o estilo de um autor. Descrito em detalhes no glossário no fim da dissertação.

${ }^{81}$ Socioleto é um conjunto de normas sociais que caracteriza um movimento estilístico. Descrito em detalhes no glossário no fim da dissertação.
} 
Tendo tal princípio como guia, os textos analisados serão postagens e threads de resposta, presentes nos sites Twitter $^{82}$, reddit $^{83}$, danbooru ${ }^{84}$, Youtube ${ }^{85}$, Imgur $^{86}$ e rule $34^{87}$ (este último com conteúdo pornográfico), bem como nos respectivos fóruns dentro dos sites de $L O L$ e Overwatch $^{88}$ e de $\operatorname{suas}^{89}$ respectivas ${ }^{90}$ Wikis $^{91}$.

A escolha de um corpus de análise tão amplo se justifica a partir do princípio do processo de leitura no ambiente digital. Espen Aarseth, no livro Cybertext: Perspective on Ergodic Literature, propõe o termo Ergódico para analisar a dinâmica de leitura que se utiliza da mecânica do hipertexto. De acordo com o autor:

Durante todo o processo cybertextual, o usuário terá efetuado uma sequência semiótica, e este movimento seletivo é um trabalho de construção física de que os vários conceitos de 'leitura' não dão conta. Este fenômeno que eu chamo de 'ergódico' usando um termo apropriado da física que deriva das palavras gregas ergon e hodos, significando 'trabalho' e 'caminho'. (AARSETH, 1997, p. 1 tradução nossa)

O processo ergódico é, portanto, um processo de leitura em que a criação do sentido acaba por transpassar o suporte material, em sua concepção mais tradicional, e acontecer através da navegação entre diversos hiperlinks, concebendo o texto lido nesta ordem particular como um

82 TWITTER. Twitter. Twitter.inc. <https://twitter.com/home>. Acesso em: 26 mai. 2020.

${ }^{83}$ REDDIT. Reddit. Reddit. <https://www.reddit.com/>. Acesso em: 26 mai. 2020.

${ }^{84}$ DANBOORU. Dambooru. Dambooru. <https://danbooru.donmai.us//>. Acesso em: 26 mai. 2020.

${ }^{85}$ YOUTUBE. Youtube. Youtube. 〈https://www.youtube.com//>. Acesso em: 29 mai. 2020.

${ }^{86}$ IMGUR. Imgur. Imgur. <https://imgur.com//>. Acesso em: 31 mai. 2020.

${ }^{87}$ RULE 34. Rule 34. Paheal <https://rule34.paheal.net//>. Acesso em: 29 mai. 2020.

${ }^{88}$ OVERWATCH WIKI. Overwatch. Gamepedia. <https://Overwatch.gamepedia.com/Overwatch_Wiki/>. Acesso em: 26 mai. 2020.

89 LEAGUE OF LEGENDS WIKI. League of Legends. Fandom. <https://leagueoflegends.fandom.com/wiki/ League_of_Legends_Wiki/>.Acesso em: 26 mai. 2020.

${ }^{90}$ OVERWATCH WIKI. Overwatch. Fandom. <https://Overwatch.fandom.com/wiki/Overwatch_Wiki/>. Acesso em: 26 mai. 2020.

${ }^{91}$ Wiki é um tipo de website que pode ter seu conteúdo editado por usuários, desenvolvido inicialmente por Ward Cunningham em 1994. Geralmente a autoria é atribuída a um enunciador difuso, nomeado como a comunidade da internet. Descrito em detalhes no glossário no fim da dissertação. 
cybertexto. Enquanto este tipo de fluxo livre entre hiperlinks pode propiciar uma experiência mais autoral na apreensão das informações, o processo ergódico pode também promover resultados não esperados:

O cybertexto põe seu possível leitor em risco: o risco de rejeição. O esforço e energia demandado pelo cybertexto de seu autor aumenta os riscos da interpretação em relação à intervenção. Tentar conhecer o cybertexto é um investimento de improvisação pessoal que pode resultar em intimidade ou falha. (...) uma disputa que não apenas por insight interpretativo, mas também por controle narrativo: 'eu quero que este texto conte a minha história; a história que não poderia ser contada sem mim'. Em alguns casos isto pode ser literalmente verdade. Em outros casos, talvez na maioria deles, a noção de narrativa individual é ilusória, mas independente disso o aspecto da coerção e da manipulação é real (AARSETH, 1997, p. 4 - tradução nossa)

Baseado nas noções propostas por Aarseth sobre os conceitos de hipertexto, cybertexto e leitura ergódica, esta pesquisa selecionou um grupo de sites de fóruns de discussão limitado, que não correspondem à totalidade dos cybertextos que podem ser criados ou referidos pela navegação dos usuários, mas que representam uma parte expressiva das conversas sobre os jogos analisados, estes sites agem como se fossem nós dentro da rede do hipertexto, por onde a maior parte das informações acaba por circular e por onde grande parte dos jogadores e fãs acabam por circular durante sua leitura ergódica.

A interação ergódica dos fãs e jogadores de $L O L$ e Overwatch nos sites que compõe o corpus para a pesquisa dos fóruns, acaba por fazer com que o conjunto de jogos (já analisado nos capítulos anteriores) e o conjunto de fóruns (a ser analisado nos próximos capítulos) se comportem como textos-contextos uns dos outros, especificamente textos-contextos situacionais.

O jogo, por ser a origem e razão de existência dos fóruns, é o contexto referencial que reúne grande parte das isotopias e figuras utilizadas nas interações, e por sua vez, as movimentações nos fóruns acabam por guiar e explicar as alterações de funcionalidade, isotopias e figuras presentes em cada novo patch nos jogos. Os contextos internos e externos são preenchidos pelo que esta pesquisa nomeou como Manifestação cultural dominante, com sua relação de dominância e combate de certos discursos.

O recorte de objeto proposto nesta pesquisa, embora inusitado, busca seguir uma interpretação mais abrangente do conceito de texto, mas que encontre suporte dentro da própria 
teoria greimasiana. Segundo Matheus Schwartzmann, a partir da do adágio greimasiano "fora do texto não há salvação", uma das duas interpretações (que não são excludentes) possíveis é a de que "Tudo é texto. Não se pode levar a cabo uma análise sem que se tome uma dada grandeza semiótica como um texto. Esta segunda maneira de ler o adágio greimasiano (...) possibilitou, para a teoria (...) um avanço muito importante" (SCHWARTZMANN, 2018, p. 2).

O avanço descrito por Matheus Schwartzmann é referente às teorias de Floch e Landowski, por exemplo, que tomam como texto a comunicação e as situações, respectivamente. Para que tais extrapolações do sentido tradicional de texto possam ser promovidas é necessário, segundo Schwartzmann, reconhecer as estruturas constituintes da significação do objeto. Tal princípio é baseado no princípio do nível ótimo de análise, proposto por A.J. Greimas em Maupassant: A semiótica do texto: exercícios práticos e citado por Schwartzmann. Segundo o excerto "Uma tática particular, para a abordagem de cada objeto discursivo, consiste em adotar o nível ótimo de análise, o melhor aproprido ao objeto, permitindo deliberar, ao mesmo tempo sobre a especificidade de um texto e sobre os modos de sua participação no universo socioletal" (GREIMAS ${ }^{92}, 1993$, p. 9 apud SCHWARTZMANN, 2018, p. 3).

Esta pesquisa propõe então que a análise deste grupo limitado de sites, objeto abrangente, porém incompleto, é o nível ótimo de análise para a observação das táticas de sanção da veridicção dos discursos dentro dos fórum, pois é capaz de abranger a estrutura de construção de sentido gerada pelos cybertextos da leitura ergódica de Aarseth, responsáveis pela criação das pluriisotopias que recobrem as personagens e o universo dos jogos do corpus da pesquisa, sendo também a segunda metade de uma relação texto-contexto que os fóruns possuem com os jogos, analisados no capítulo anterior.

Após definido o corpus a ser analisado, deve-se falar sobre a metodologia de sua abordagem. A semioticista brasileira Norma Discini publicou um artigo em 2015, chamado "Blog e campo de presença”, em que a autora analisa semioticamente o blog de humor kibeloco, buscando entender

92 GREIMAS, Algirdas Julien. Maupassant: a semiótica do texto: exercícios práticos. Florianópolis: Editora da UFSC, 1993. 
a construção de sentido dentro de um ambiente composto por postagens e uma thread ${ }^{93}$ de respostas, dinâmica muito similar ao princípio de fórum que organiza os textos aqui analisados.

Segundo a autora, ao analisar o discurso do blog, o analista deve congelar o discurso, analisando-o como um texto finalizado, sem que se considere os hiperlinks ou mecânicas do ambiente digital. "Aquela edição, que é única e que pode ser arquivada e imprimida pelo analista, congelada pela leitura crítica portanto, permite que se examine o blogueiro como um sujeito imobilizado, em conjunção com o mundo discursivizado" (DISCINI, 2015, p. 120).

Portanto, neste trabalho serão analisados prints congelados com o conteúdo dos fóruns, para que se possa buscar as táticas discursivas de veridicção dentro de tal universo. Porém, cabe relembrar que:

É por meio de um congelamento da página que se define um meio de racionalizar a descrição analítica de tal página da web como um todo de sentido, tal qual encerrado em determinada edição de um blog. O congelamento metodológico não deixa, porém, de fazer escaparem as marcas enunciativas do sujeito mobilizado já que o próprio congelamento analítico não é definitivo: sempre se intervém com participações, ainda que mínimas, ainda que não sejam efetuados comentários e outras contribuições para as atualizações. (DISCINI, 2015, p. 126).

Este trabalho usará imagens dos fóruns que, congeladas, permitem a identificação dos enunciadores e enunciatários, bem como as dinâmicas da enunciação. Porém, o modo de funcionamento do fórum, bem como sua natureza inacabada e aberta, especialmente na criação e manipulação das isotopias e figuras, será sempre lembrado durante as análises.

É importante observar ainda, que o congelamento para análise interrompe uma dinâmica $a d$ nauseam característica do fórum: um discurso de um perfil pode ser respondido, com uma proposta veridictória que, ao mesmo tempo, se torna um discurso, também passível de ser avaliado. O texto do fórum é constantemente atualizado por veridicções sobrepostas, com o congelamento proposto por Discini se apresentando como uma forma de observar uma etapa dentro de um fluxo contínuo.

93 Thread é o jargão usado nas interações em redes sociais para designar a sequências de respostas feitas a uma mensagem (post) inicial. Descrito em detalhes no glossário no fim da dissertação. 
Uma última observação que deve ser feita sobre as delimitações do corpus será a do idioma. Esta pesquisa utilizará inicialmente posts em inglês, dada à intensidade terminológica da linguagem utilizada nos fóruns e nos jogos. Fernanda Galli, no artigo "Linguagem da internet: um meio de comunicação global" (2009) usa o termo Tecnoleto ${ }^{94}$ para se referir a terminologias "que possam dar conta das especificidades de cada grupo social, de sua natureza e característica" (GALLI, 2009, p. 157).

No caso das interações de fóruns, existem vários tecnoletos utilizados na comunicação: referentes à cultura dos jogos, à cultura dos fóruns e à própria Manifestação cultural dominante que perpassa a interação na internet. Outra característica da "linguagem da internet", e destacada por Galli, é a predileção do uso do idioma inglês para a comunicação, que por si só já é um sintoma da disputa cultural que rege a globalização idiomática das manifestações culturais dominantes.

Porém, muitos brasileiros, tailandeses, chineses e outros usuários de culturas nãoanglófonas ainda assim acabam por preferir interagir em inglês nos fóruns, pois as desenvolvedoras dos jogos $L O L$ e Overwatch, e dos fóruns Reddit e Youtube possuem sede nos Estados Unidos, e todos os objetos do corpus possuem o inglês como língua primária.

Em função de afinidades linguísticas e culturais, as notícias e acontecimentos que movem a economia e o desenvolvimentos dos jogos costumam acontecer primeiro em inglês, e os nãoanglófonos optam por circular nestes ambientes para "cortar caminho" e chegar às novidades e discussões o mais rápido possível. A preeminência do inglês sobre os demais idiomas rege, inclusive, a construção dos neologismos que, quando adotados pela comunidade, incorporam os tecnoletos.

A importância do destaque dado aos tecnoletos nesta pesquisa pode ser exemplificada pela observação de Jenkins, Ford e Green ao justificar a importância da semântica na análise da propagabilidade das mídias:

Nosso foco sobre a terminologia vai além da mera semântica. Acreditamos que a linguagem tem uma importância fundamental e que as metáforas que todos

\footnotetext{
94 Tecnoleto é um termo também denominado como "língua de especialidade". Descrito em detalhes no glossário no fim da dissertação.
} 
usamos para descrever os padrões que vemos formatam a maneira como entendemos o mundo. Ficamos cegos em relação a alguns fenômenos e preconceituosos em relação a outros (JENKINS; FORD; GREEN, 2014. P. 26).

Portanto, esta pesquisa utilizará fóruns em inglês, promovendo as traduções do idioma, que acaba por acontecer simultaneamente à tradução das terminologias dos socioletos que os fóruns utilizam, por ser neste idioma e nestes espaços anglófonos que a grande maioria das interações ocorrem.

Resumindo as primeiras considerações deste capítulo: a pesquisa se focará num conjunto de 8 fóruns (Danbooru, Reddit, Imgur, Rule 34, Youtube, Twitters relacionados aos jogos e os fóruns oficiais de LOL e Overwatch). Este corpus possui como alguns elementos definidores o uso de hiperlinks na sua constituição, bem como a assincronia entre as mensagens. Outras características incluem o suporte para interação multimídia de vídeo, som e texto, bem como uma comunicação entre membros que compartilham interesses comuns e se comunicam através de pseudônimos, utilizando diversos idiomas, mas predominantemente em inglês. Por fim, cabe também destacar que tais fóruns possuem métodos de triagem de mensagens e fóruns de conversa públicos, ainda que alguns deles abram a possibilidade para interações privadas.

Outra delimitação deve ser feita antes da análise propriamente dita do objeto: a estruturação básica dos papéis de enunciador e enunciatário dentro do nível discursivo do percurso gerativo de sentido. Para isso, deve-se retomar qual modelo de estudo da enunciação será utilizado nesta pesquisa.

\section{$3.2 O$ nível discursivo}

Para analisar a enunciação dentro do espaço do fórum, é necessário antes estabelecer quais as posições ocupadas durante a enunciação e a construção do sentido dentro o espaço do fórum. Para isso, será analisado brevemente o funcionamento do nível narrativo dentro da semiótica greimasiana. 
Segundo Fiorin (2014), o nível discursivo é o local onde "as formas abstratas do nível narrativo são revestidas de termos que lhes dão concretude" (FIORIN, 2014. p. 41):

Figura 23 - Resumo do Percurso Gerativo de Sentido.

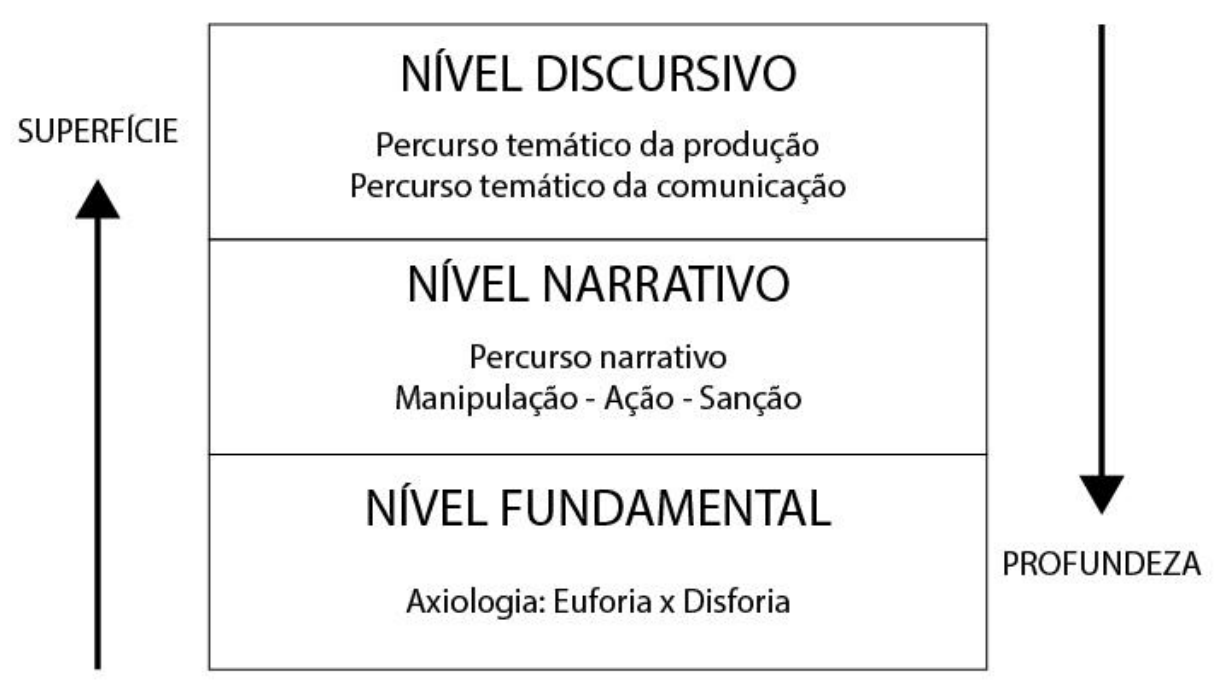

Fonte: imagem nossa.

Na figura acima, se encontra resumido o percurso gerativo de sentido greimasiano. Esta divisão, de caráter metodológico, busca estruturar a construção do sentido em três áreas. O nível fundamental, considerado como o nível mais profundo, é onde se analisa a axiologia fundamental que rege os valores do texto, a partir de uma oposição lógica, onde um acontecimento é eufórico e o seu contrário, é disfórico. A narrativa de Tarzan (1999) da Disney, por exemplo, é uma história que opõe os contrários Natureza e Tecnologia, onde o primeiro é o termo eufórico (representado pelo herói Tarzan) e o último, o termo disfórico (representado pelo vilão Clayton e seus caçadores de gorilas).

O nível intermediário, chamado narrativo e já discutido no capítulo anterior, é quando esta oposição axiológica é narrativizada dentro do modelo proposto de um sujeito, manipulado por um destinador, é modalizado em busca de um objeto de valor. É neste ponto que os sujeitos do texto passam a agir e a receber reações e sanções do mundo.

E por fim, o nível discursivo é o nível mais superficial, pois é onde estão os elementos visíveis do texto. Um mesmo percurso narrativo pode receber diferentes recobrimentos figurativos 
dentro do nível discursivo: se tomarmos como referência uma narrativa comum dos filmes dos estúdios Walt Disney, onde um sujeito, modalizado pelo querer, pelo dever e pelo poder, se sacrifica para entrar em conjunção com seu objeto de desejo, que é o bem-estar de sua amada, e ao final recebe uma sanção positiva, tendo sua vida restaurada. Se, no nível discursivo, o recobrimento figurativo é a Grécia antiga, temos Hércules (1997), se por outro lado o recobrimento é a França monarquista, temos A Bela e a Fera (1991).

Enquanto são necessários os três níveis para que os valores psico/sócio/ideológico sejam compreendidos, é analisando-se o nível discursivo que eles podem ser vistos com mais clareza, pois estão cristalizados em isotopias, figuras e no uso sintáxico. Segundo Pessoa de Barros:

O discurso é fabricado como decorrência de necessidade /dever ser/ do receptor ou de seu desejo /querer ser/ de certos valores, segundo a interpretação do destinador, e com o objetivo de se constituir em lugar de inscrição, manipulação e veiculação desses valores. A necessidade, em geral interpretada como precisão e questão econômica, e o prazer estético do texto distinguem-se, mas não recobrem a oposição do social ao individual. Ambos, interesse econômico e prazer estético, dizem respeito a grupos sócio-históricamente determinados e atendem a diferentes necessidades do homem, oriundas da sociedade. (BARROS, 1988, p. 141-142).

Diana Pessoa de Barros analisou mais detalhadamente o funcionamento do nível discursivo em seu livro Teoria do Discurso: Fundamentos Semióticos (1988). Segundo ela, o nível discursivo pode ser considerado como a neutralização de dois percursos temáticos: o percurso temático da produção e o percurso temático da comunicação. "O tema da produção é o da ação do homem sobre as coisas, transformando-as ou construindo-as; o da comunicação, o da ação do homem sobre os outros homens" (BARROS, 1988, p. 136).

De acordo com o princípio de imanência da semiótica, onde o modelo de análise deve fornecer todos os dados e métodos de uma análise, Pessoa de Barros (1988) propõe que os dois percursos sejam analisados utilizando a mesma mecânica da etapa de manipulação do nível narrativo, analisado no capítulo anterior. Aplicando esta premissa no nível discursivo, temos o seguinte modelo:

Figura 24 - Apresentação dos percursos temáticos do nível Discursivo. 


\begin{tabular}{|c|c|c|c|c|}
\hline 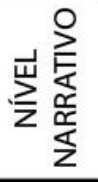 & $\begin{array}{l}\text { Percurso narrativo } \\
\text { da Manipulação }\end{array}$ & $\begin{array}{l}\text { DESTINADOR } \\
\text { MANIPULADOR }\end{array}$ & $\begin{array}{l}\text { DESTINATÁRIO } \\
\text { SUJEITO }\end{array}$ & $\begin{array}{l}\text { DESTINADOR } \\
\text { JULGADOR }\end{array}$ \\
\hline \multirow{2}{*}{ 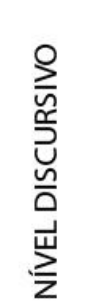 } & $\begin{array}{l}\text { Percurso temático } \\
\text { da Comunicaçáo }\end{array}$ & ENUNCIADOR & ENUNCIATÁRIO & (ENUNCIADOR) \\
\hline & $\begin{array}{l}\text { Percurso temático } \\
\text { da Produçăo }\end{array}$ & PRODUTOR & $\begin{array}{l}\text { SUJEITO DA } \\
\text { ENUNCIAÇÃO }\end{array}$ & $\begin{array}{c}\text { RECEPTOR } \\
\text { INTERPRETANTE }\end{array}$ \\
\hline
\end{tabular}

Fonte: imagem nossa, adaptada de Pessoa de Barros (1988).

Pessoa de Barros argumenta que os percursos temáticos de comunicação e de produção possuem uma estrutura de manipulação, similar a etapa de manipulação do nível narrativo.

No caso do percurso da comunicação, um enunciador, entidade cuja função é equivalente ao destinador do nível narrativo, enuncia um discurso, imprimindo neste marcas e valores ideológicos, com o objetivo de comunicá-los ao enunciatário, a entidade para quem a enunciação é feita. O objetivo do enunciador é manipular o enunciatário, para levá-lo a uma modalidade de crer e numa modalidade de fazer.

Toda a enunciação é concebida pelo enunciador, e este possui a seu dispor algumas formas de imprimir os valores desejados, bem como as formas de construir a si e a seu enunciatário, pois devemos sempre lembrar que "O fazer persuasivo do enunciador realiza-se, conforme foi examinado na análise das estruturas narrativas e discursivas, no e pelo discurso" (BARROS, 1988, p. 137)

Uma destas formas é a sintaxe ${ }^{95}$. É através da das marcas da sintaxe que o enunciador pode marcar a presença da enunciação no enunciado, portanto marcar (ou esconder) um $e u$, um $t u$ e um

\footnotetext{
95 Parte da linguística que estuda as palavras e suas relações organizacionais dentro de uma frase. Descrito em detalhes no glossário no fim da dissertação.
} 
ele, bem como exibir ou esconder as marcas espaciais e temporais. Outra forma é a semântica ${ }^{96}$, onde as formações ideológicas do discurso podem ser percebidas pelos percursos figurativos, temáticos e pelas escolhas das isotopias.

Tais enunciadores e enunciatários podem se desdobrar em narradores/narratários e interlocutor/interlocutário. Porém, em todos estes casos, as construções e relações descobertas pelo estudo da semântica e sintaxe discursivas remetem à enunciação do enunciado, portanto ao trabalho do enunciador. É o enunciador que escolhe as figuras, temas e dêiticos, pensando nos valores sociopsico-históricos embutidos no discurso, na imagem e valores que vai construir de si e também na imagem e valores dos que pretende convencer.

O conteúdo do discurso e os valores que ele evoca é o que pode ser chamado de $\operatorname{Logos}^{97}$, enquanto a imagem que pode ser analisada, via discurso, do enunciador e o enunciatário envolvidos na comunicação não são sujeitos ontológicos, mas sim um ethos $^{98}$ do enunciador e um pathos ${ }^{99}$ do enunciatário, respectivamente. "A imagem do enunciador, o ethos, e também a do enunciatário, o pathos, exercem um papel central na compreensão tanto das opções enunciativas quanto da eficácia do discurso" (FIORIN, 2008, p. 150).

Eco (2017) também pensa sobre o papel do ethos e o pathos na construção de sentido, chamando-os de autor-modelo e um leitor-modelo, e afirma que não tem interesse no autor empírico. Bem como descreve o leitor-modelo como "uma espécie de tipo ideal que o texto não só prevê como colaborador, mas ainda procura criar"' (ECO, 2017, p. 15). A existência deste leitor pressupõe "observar as regras do jogo, e o leitor-modelo é alguém que está ansioso para jogar” (p. 16). Daí vem a importância de tal distinção: Tanto o ethos quanto o pathos são criados pelo trabalho do enunciador, portanto são fundamentais na criação da "verdade do texto", uma enunciação que

\footnotetext{
96 Parte da linguística que estuda as palavras como valores e significados dentro de uma língua e uma cultura. Descrito em detalhes no glossário no fim da dissertação.

${ }^{97}$ Logos é o conteúdo lógico de um argumento. Descrito em detalhes no glossário no fim da dissertação.

98 Ethos é a imagem que se faz do enunciador de um discurso. Descrito em detalhes no glossário no fim da dissertação.

${ }^{99}$ Pathos é a imagem que se faz do enunciatário de um discurso. Descrito em detalhes no glossário no fim da dissertação.
} 
não encontrará resistência alguma ao ser enunciada. O enunciador é validado por seu enunciatário e não há entre eles ruídos pois são fruto do mesmo arcabouço de valores psico-sócio-históricos.

Quando se pensa numa configuração ainda mais abrangente, entra-se no percurso temático da produção do discurso que será comunicado no percurso temático da comunicação. De acordo com a tabela acima, na posição de sujeito manipulado, o conjunto enunciador/enunciatário é sincretizado na figura do sujeito da enunciação. Este tipo específico de sujeito é o que comporta toda a performance da criação do discurso, do ethos, do pathos e do logos, bem como os elementos utilizados para sua criação, pois "o objeto fabricado sempre traz as marcas de seu fabricante e de sua fabricação (BARROS, 1988, p. 140). São estas marcas que a análise da semântica e sintática do discurso visam expor.

Na posição do manipulador, se encontra o Produtor do discurso. Esta figura é o "destinadormanipulador responsável pela competência do sujeito da enunciação e origem de seus valores. Deve ser entendido como destinador sócio-histórico (ou psico-sócio-histórico)" (BARROS, 1988, p. 140-141). Já na posição do julgador, se encontra o Receptor-Interpretante, este pode ser considerado como "papel temático do destinador julgador, julga e sanciona o fazer do sujeito da enunciação, com base no contrato passado entre destinador-produtor e sujeito (p. 141).

Tal produtor e tal receptor-interpretante ainda assim não se relacionam a sujeitos ontológicos, mas sim a sujeitos psico-sócio-históricos, que podem ser acessados parcialmente pelo próprio texto analisado, e em sua totalidade pelos contextos, descritos início do tópico 3.1. Definidos estes pontos de partida, cabe observar como os fóruns elencados neste capítulo podem ser observados dentro destas categorias:

Figura 25 - Apresentação de proposta de distribuição nos percursos temáticos do nível Discursivo. 


\begin{tabular}{|c|c|c|c|c|}
\hline 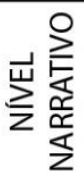 & $\begin{array}{l}\text { Percurso narrativo } \\
\text { da Manipulação }\end{array}$ & $\begin{array}{l}\text { DESTINADOR } \\
\text { MANIPULADOR }\end{array}$ & $\begin{array}{l}\text { DESTINATÁRIO } \\
\text { SUJEITO }\end{array}$ & $\begin{array}{l}\text { DESTINADOR } \\
\text { JULGADOR }\end{array}$ \\
\hline \multirow{2}{*}{ 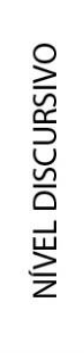 } & $\begin{array}{l}\text { Percurso temático } \\
\text { da Comunicação }\end{array}$ & $\begin{array}{c}\text { ENUNCIADOR } \\
\text { Perfil }\end{array}$ & $\begin{array}{c}\text { ENUNCIATÁRIO } \\
\text { Perfil/ } \\
\text { Comunidade }\end{array}$ & (ENUNCIADOR) \\
\hline & $\begin{array}{l}\text { Percurso temático } \\
\text { da Produção }\end{array}$ & $\begin{array}{c}\text { PRODUTOR } \\
\text { Usuário }\end{array}$ & $\begin{array}{c}\text { SUJEITO DA } \\
\text { ENUNCIAÇÃO } \\
\text { Perfil }\end{array}$ & $\begin{array}{c}\text { RECEPTOR } \\
\text { INTERPRETANTE } \\
\text { Comunidade }\end{array}$ \\
\hline
\end{tabular}

Fonte: imagem nossa, adaptada de Pessoa de Barros (1988).

Ao pensar no princípio da autoria do eixo produtor-enunciador, é preciso circunscrever a dinâmica do fórum. O blog, objeto de natureza similar ao fórum e já analisado semioticamente por Discini (2015), possui um autor que é transversal, aberto e regido pela mistura. Porém os fóruns e páginas que serão analisados nesta pesquisa não possuem, em sua maioria, uma figura similar à de "autor", pois qualquer perfil de usuário registrado pode iniciar o post que dará origem à thread, bem como os sites não se restringem às publicações de apenas um autor ou grupo de autores. Todas as interações e comentários no fórum são operadas via perfis.

\subsection{Os perfis e os comentários}

Os perfis são as identidades que podem enunciar discursos dentro dos fóruns e sites analisados nesta pesquisa. Estes perfis são criados pelos usuários de acordo com regras específicas, vigentes dentro do site onde este será utilizado. A quantidade de informação que um perfil possui pode variar, mas geralmente são compostos por um nome e uma imagem principais, bem como uma página pessoal dentro do próprio fórum, onde podem ser apresentadas toda a sorte de informações desejadas pelo operador do perfil. Nos casos dos fóruns oficiais dos jogos analisados, esta página pessoal pode exibir uma lista de conquistas e estatísticas do operador, quando este age como jogador no LOL ou no Overwatch.

Figura 26 - Colagem mostrando os perfis de usuário. Em sentido horário: Fandom, Reddit e Rule 34. 


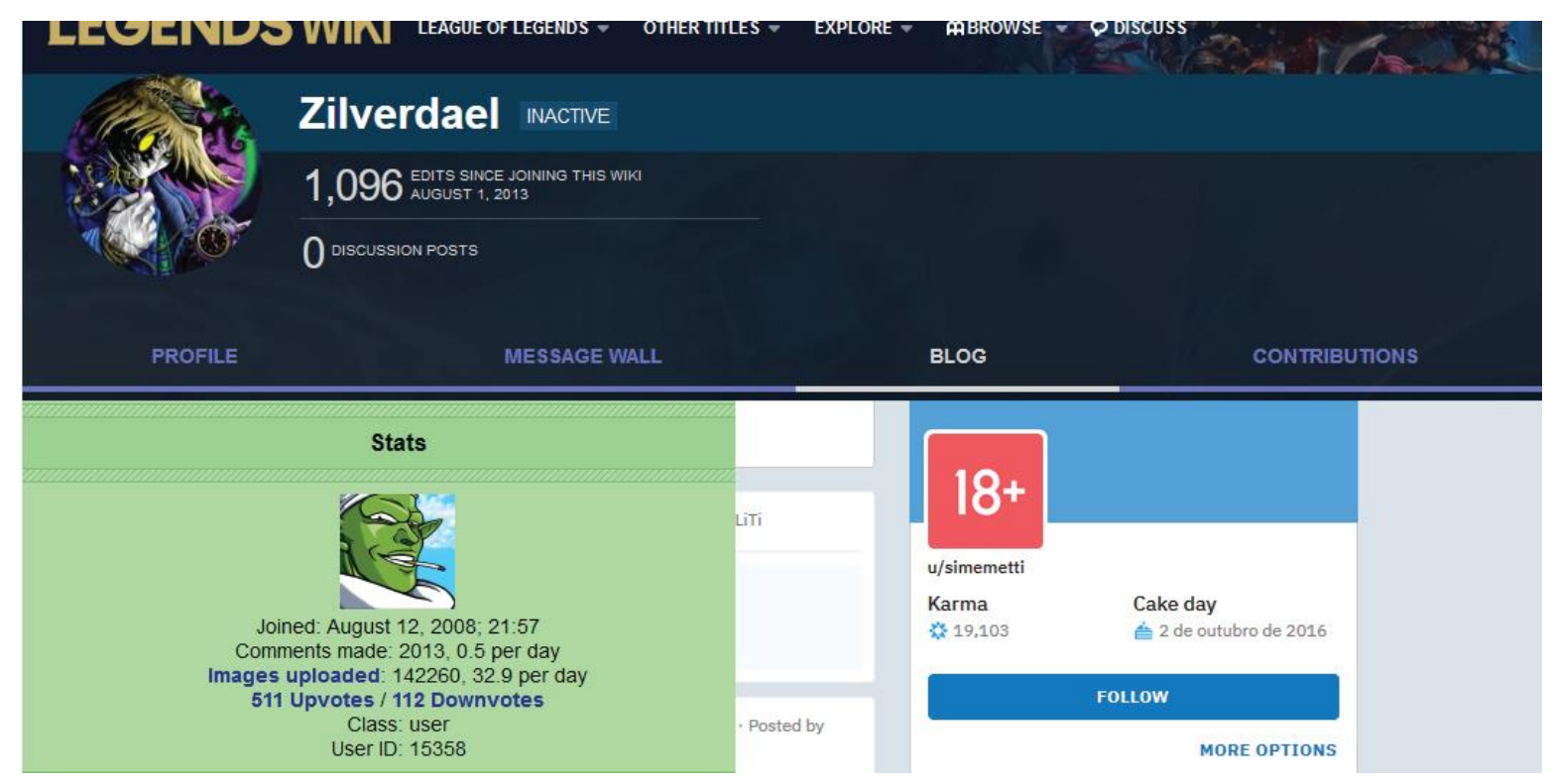

Fonte: imagem nossa, adaptada de Fandom (2020), Reddit (2020) e Rule $34(2020)^{100}$.

Vale notar que, ao comunicar-se no ambiente digital, o usuário médio não possui métodos para comprovar se o conteúdo de um perfil com o qual interage possui correspondência com o mundo real ou não, sendo prática comum em tais perfis o uso de ícones, memes ou desenhos digitais no lugar da foto do usuário, e a inserção de informações falsas, aleatórias ou claramente fantasiosas nos dados de cadastramento que serão exibidos para os demais membros do site ou fórum. Umberto Eco, numa de suas colunas na revista L'espresso, registrou a recorrência de tal fenômeno no ambiente digital:

Não tenho Twitter nem estou no Facebook. A Constituição me permite isso. Mas é claro que há no Twitter um falso perfil meu, assim como um falso Casaleggio. Certa vez, uma senhora me disse com o olhar cheio de reconhecimento que sempre me lê no Twitter e que já interagiu muitas vezes comigo, para seu grande proveito intelectual. Tentei explicar que se tratava de um falso eu, mas ela olhou para mim como se estivesse dizendo que eu não sou eu. Se estava no Twitter, eu existia. Tuíto ergo sum. (ECO, 2017b, p. 35)

Há, além dos elementos construtivos, diversas práticas conhecidas no ambiente de sites e fóruns de jogos, que costumam cristalizar o ethos e o pathos do sujeito da enunciação em fórum

100 Disponível em: <https://leagueoflegends.fandom.com/wiki/User:Zilverdael>, <https://rule34.paheal.net/user/ Gackt>, <https://www.reddit.com/user/simemetti/>. Acesso em: 10 mar. 2021. 
como o de um sujeito duvidoso, que pode ser falso ou mentiroso. Marcuschi fala em "construção das identidades sociais em uma espécie de contínuo" (MARCUSCHI, 2009, p. 78), afirmando que as interações em ambiente digital podem se dar entre indivíduos conhecidos, desconhecidos, anônimos e irreais.

Existem perfis criados com o intuito de gerar um comportamento disruptivo e destrutivo dentro das comunicações dos demais perfis no site, os chamados trolls, bem como um mesmo operador pode possuir múltiplos perfis no mesmo fórum, fazendo com que seus próprios perfis interajam entre si, simulando uma conversa entre mais de um operador. Anne Jamison afirma que, na comunidade dos escritores de fanfic "Ás vezes, escritores assumem identidades fantasmas para elogiar e promover seu próprio trabalho e destruir o trabalho de seus rivais" (JAMISON, 2017, p. 121).

Para além de tais táticas, conhecidas entre usuários de fóruns, o perfil pode ter enunciações apagadas e modificadas por si mesmo ou por moderadores da página (caso suas enunciações incorram contra as diretrizes de comportamento do próprio fórum).

Figura 27 - Destacado em vermelho, comentário feito no fórum do Reddit sobre Overwatch. O autor deletou sua própria postagem três dias depois de fazê-la.
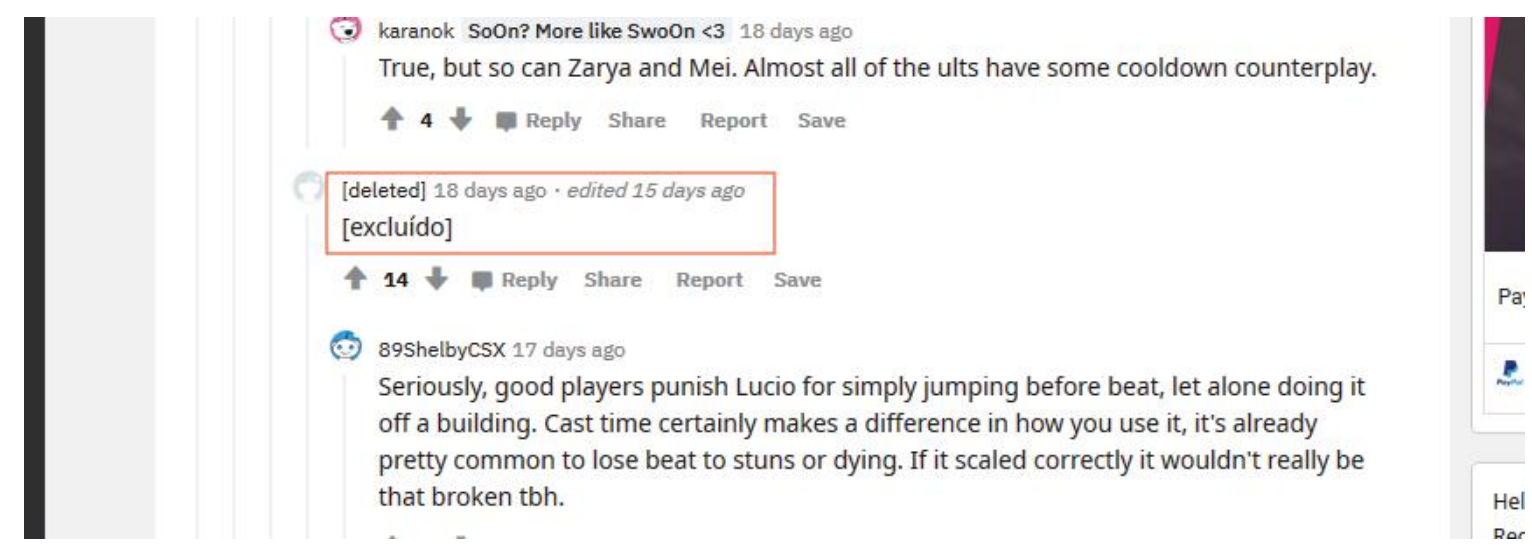

Fonte: imagem nossa, adaptada de Reddit $(2020)^{101}$.

101 Disponível em: <https://i.reddit.com/r/Overwatch/comments/gtip47/i_used_the_workshop_to_make_lucios_beat_ increase/>. Acesso em: 10 mar. 2021. 
Figura 28 - Destacado em vermelho, comentário de um usuário, que foi deletado por um moderador. As interações com o post deletado se mantém.
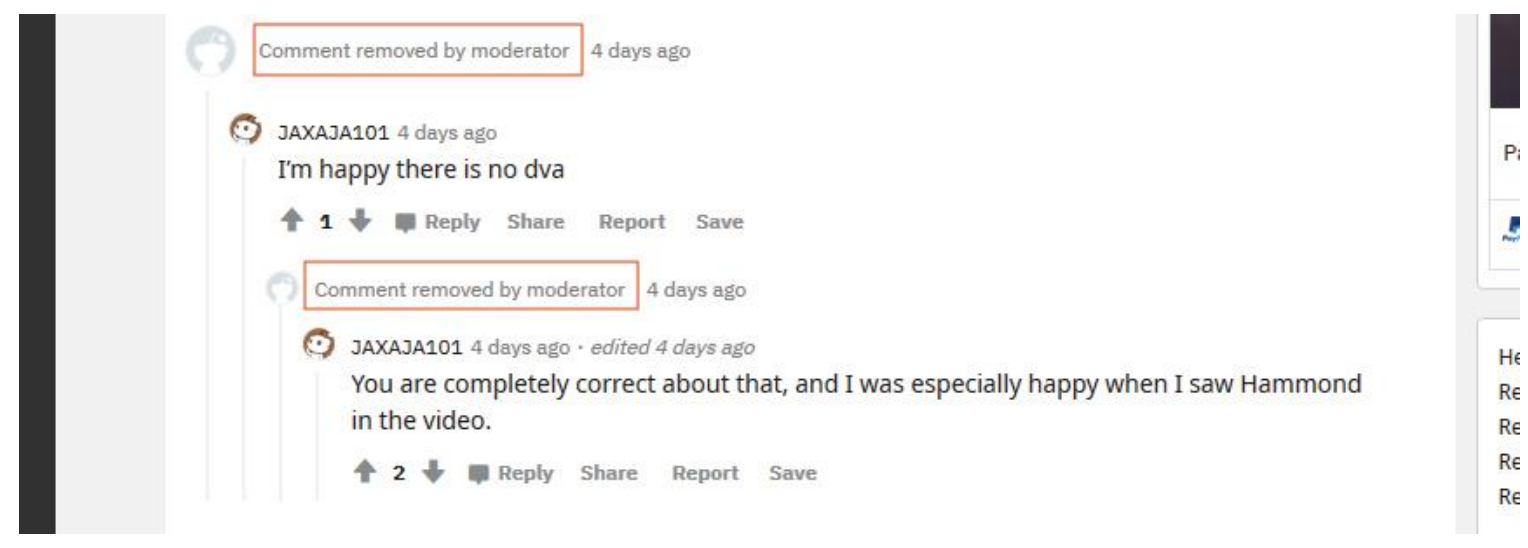

Fonte: imagem nossa, adaptada de Reddit $(2020)^{102}$.

Ainda sobre tais particularidades do uso dos perfis, estas cristalizam também um ethos de transitoriedade e indefinição a respeito do enunciador, presentes também no estudo de Discini (2015) sobre os blogs. Segundo a autora, "É uma mistura de enunciados, de enunciações, e dos próprios valores que fundam a presença exposta à transversalidade actancial favorecida pela internet" (DISCINI, 2015, p. 94).

Ainda a respeito do blog, a autora postula que este efeito de bricolagem textual, em que o excesso de diversos links, imagens, textos e citações constroem o corpo e a presença do blogueiro na internet, permite a este "autor" recorte o mundo de seu próprio jeito. Isto faz deste autor do blog:

Um corpo fluído, por que atrelado à fluidez de suporte - considerado este na acepção de configuração material própria à textualização. É um corpo fluído também devido à impregnação do sentido ambivalente, próprio ao princípio cômico. (DISCINI, 2015, p. 107)

Em relação à tabela 12, esta pesquisa propõe que o enunciador do percurso temático da comunicação, e o sujeito da enunciação do percurso temático de produção seja o perfil, um avatar construído por um operador, que ocupa o lugar do produtor do discurso no percurso temático de

102 Disponível em: <https://www.reddit.com/r/Overwatch/comments/h7zn6v/i_made_an_ow_anime_opening/>. Acesso em: 10 mar. 2021. 
produção. O operador é o sujeito psico-socio-histórico que modula e manipula os valores que são enunciados pelo perfil, como enunciador e sujeito da enunciação do texto-jogo

Outra observação necessária sobre o sujeito da enunciação pode ser feita a respeito do caráter coletivo de seus participantes. Marcuschi (2009) fala sobre um conceito de relações hiperpessoais. Segundo o autor, ambientes de fórum ou chat se dá "uma relação mais hiperpessoal do que interpessoal, pois a participação não é centrada no indivíduo e nas relações individuais e sim no grupo" (MARCUSCHI, 2009, p. 57)

Diana Pessoa de Barros, no capítulo "a comunicação humana” do livro didático Introdução â linguística I: Objetos teóricos (2015) fala a respeito da dinâmica de entrevista, um modo de comunicação descrita da seguinte forma:

No caso da entrevista, na televisão ou na imprensa escrita, estabelecem-se três relações na comunicação: entre o entrevistador e o entrevistado, entre $o$ entrevistador e o público, entre o entrevistado e o público. Em outras palavras, a relação entre o entrevistador e o entrevistado, que é a única explicitada nessa comunicação "alargada", dependerá (...) também das relações dos interlocutores com o público. Na verdade, a comunicação com o público é o objetivo primeiro da comunicação entre entrevistador e entrevistado. Cria-se entre entrevistador e entrevistado uma interação particular, em que eles são cúmplices nas tarefas de informar e convencer o público e, ao mesmo tempo, oponentes na conquista dessa audiência (BARROS, 2015, p. 46)

Outro autor que reconhece os efeitos de tal dimensão expositiva é Roland Barthes. Em seu livro A câmara clara (2015), ao elaborar sobre o processo de leitura fotográfico, o autor postula a existência de três práticas: Operator (o fotógrafo), Spectator (quem observa a foto) e o Spectrum ${ }^{103}$ (quem é fotografado).

Sobre o spectrum, Barthes propõe uma impossibilidade de se permanecer "neutro" diante da objetiva da câmera, de realizar uma performance. Para o autor:

Posando diante da objetiva (quero dizer: sabendo que estou posando, ainda que fugidiamente), não me arrisco tanto (pelo menos por enquanto). (...) eu vivo na angústia de uma filiação incerta: uma imagem - minha imagem - vai nascer: vão

103 Spectrum é o termo proposto por Barthes para a pessoa que é o alvo da fotografia. Descrito em detalhes no glossário no fim da dissertação. 
me fazer nascer de um indivíduo antipático ou de um 'sujeito distinto'? Se eu pudesse 'sair' sobre o papel como sobre uma tela clássica, dotado de um ar nobre, pensativo, inteligente etc.! (...) Infelizmente, estou condenado pela fotografia, que pensa agir bem, a ter sempre uma cara: meu corpo jamais encontra seu grau zero, ninguém dá a ele. (BARTHES, 2015, p. 18-19).

Esta sensação de ser um spectrum, prática ambígua e impotente diante das interferências do operator e do spectator, está presente em todas as interações discursivas do fórum, que ficam registradas, e se tornam objeto para os spectators alheios.

Para esta pesquisa, tal dinâmica de entrevista parece ser uma forma construtiva de considerar a interação discursiva. O perfil enunciador, através de sua ação como o sujeito da enunciação, disputa e compartilha com diferentes perfis enunciatários que respondem e comentam, a construção do sentido, enquanto a função de sancionador final da enunciação e seus percursos propostos é atribuída a uma coletividade que frequenta tais fóruns. Esta audiência pode ser chamada de comunidade. É esta comunidade, do qual tanto o perfil enunciador quanto o perfil enunciatário fazem parte, o sancionador do discurso do fórum sobre os jogos.

Em relação à tabela 12, esta pesquisa propõe que o papel julgador, tanto no percurso temático da comunicação quanto no percurso temático da produção, é a comunidade. Ainda que o enunciatário do percurso da comunicação possa ser um perfil nominal, a natureza pública da interação a transforma num espetáculo que é, em última instância, feito para buscar uma sanção por parte da comunidade.

Definidos os papéis que perfis, comunidade e operadores terão dentro do nível discursivo do percurso gerativo de sentido, uma primeira conclusão já pode ser traçada a respeito das estratégias de veridicção no ambiente de fórum. Tanto o ethos do enunciador do fórum, desconfiável e irônico, quanto o pathos do enunciatário do fórum, um coletivo que engloba todo e qualquer interessado, são construídos em grande parte pelo modo como os elementos textuais e interativos são tratados no fórum.

O sujeito fluído, misturado e transversal, observado por Discini, é um sujeito que resiste de forma mais direta ao escrutínio de seus julgadores. Por causa do processo de leitura ergódica descrito por Aarseth, é difícil observar, em sua integridade, o ethos do enunciador, pois este pode 
esconder e apagar enunciações, bem como alterar as informações do próprio perfil quando bem entender, mostrando aos demais faces diferentes atribuídas à mesma enunciação.

Outro elemento disponível para o enunciador, e que dificulta a identificação do produtor por parte do receptor, é a padronização das ferramentas de produção dos posts. Este tipo de estrutura automatiza ferramentas textuais, inserção de textos de outrem, bem como o uso de elementos multimídia como gifs e vídeos. Isto permite a um enunciador, que não possua uma prática enunciativa ou descritiva adequada ou ainda não possua conhecimentos sobre o tema, poder camuflar tais marcas de si mesmo como produtor, através de ferramentas de edição da máquina e das multimídias da internet. Komesu (2009), ao estudar Blogs, corrobora esta visão ao afirmar que “A facilidade para a edição, atualização e manutenção dos textos em rede foi - e é - os principais atributos para o sucesso e a difusão dessa chamada ferramenta de auto-expressão" (KOMESU, 2009, p. 136).

Figura 29 - Captura de tela do site Reddit, demonstrando os recursos disponíveis na plataforma, destinados a auxiliar a enunciação de seus usuários. 


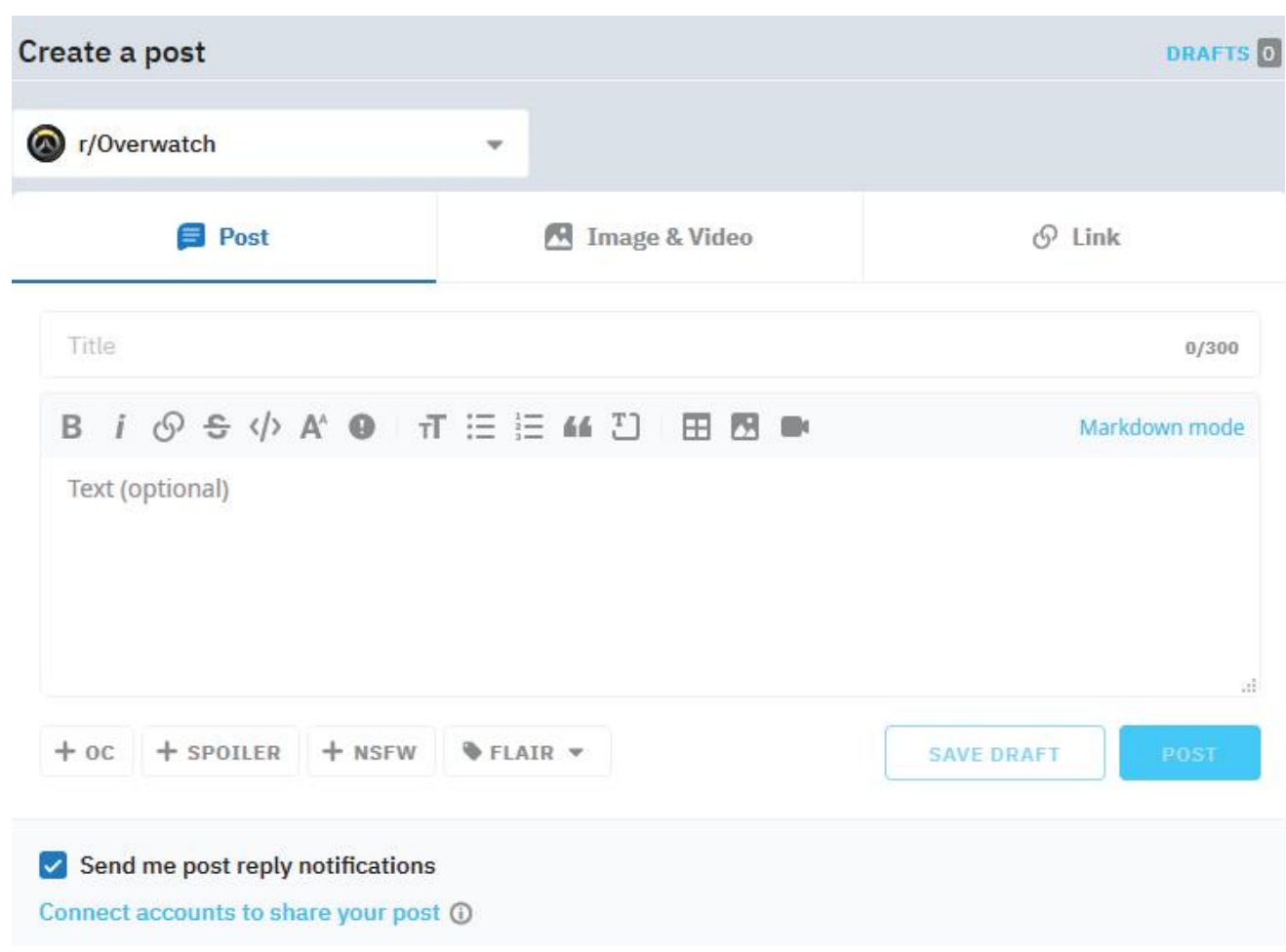

Fonte: Reddit (2020) ${ }^{104}$.

O uso de uma temporalidade bem-marcada (com indicação da data e hora de cada postagem do perfil) bem como uma espacialidade não-marcada (a ausência de marcação espacial da postagem) permitem, segundo Komesu, uma "vontade do indivíduo de 'ritmar o tempo' para a historização de si mesmo" (KOMESU, 2009, p. 140). A massificação das ferramentas para a produção dos perfis, bem como a facilidade que o cybertexto possibilita para que se copiem informações para construir o próprio perfil, cria meios para que o operador por trás do perfil controle sua aparência de forma a se "expor" o menos possível e, ao invés disso, hiper expor sua persona digital, o perfil. Ainda sobre tais possibilidades:

Por meio de links, textos escritos, imagens e sons podem ser associados de modo não linear em um 'mundo textual sem fronteiras', visto que as ligações eletrônicas podem ser realizadas entre textos em um número virtualmente ilimitado. A interatividade característica do suporte é evidenciada nessa produção de escritos sobre si veiculados de maneira pública pela internet. Não se trata dos segredos do indivíduo, velados pelas práticas diaristas tradicionais. Os blogs são redigidos

${ }^{104}$ Disponível em: <https://www.reddit.com/submit>. Acesso em: 10 mar. 2021. 
para que as histórias pessoais sejam compartilhadas abertamente (KOMESU, 2009, p. 144).

Sobre as funções disponíveis ao produtor do discurso, é interessante que sejam ressaltadas duas: A primeira é a possibilidade de se responder posts específicos dentro da thread de um fórum. Isto pode acontecer através de uma hierarquização visual dos comentários, onde linhas verticais contínuas enfileiram as respostas de um post, ou através de uma citação direta na própria resposta.

Figura 30 - Respostas no modelo de hierarquização visual dos comentários.

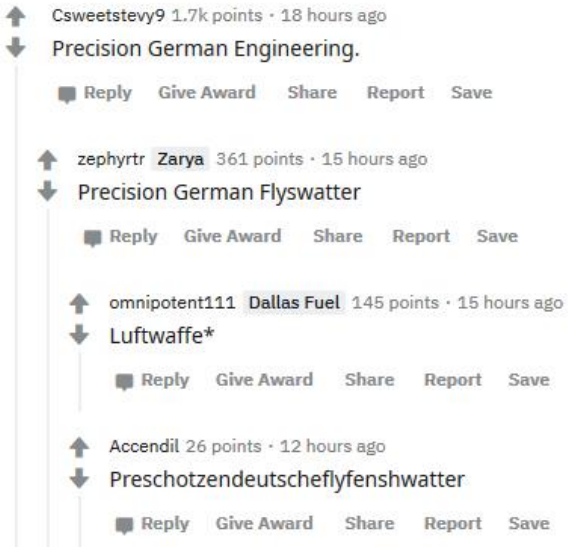

Fonte: Reddit $(2020)^{105}$.

Figura 31 - Respostas no modelo de citação direta.

${ }^{105}$ Disponível em: <https://www.reddit.com/r/Overwatch/comments/jellu6/everyone_you_cant_pin_a_mercy_while_ shes_flying/>. Acesso em: 10 mar. 2021. 


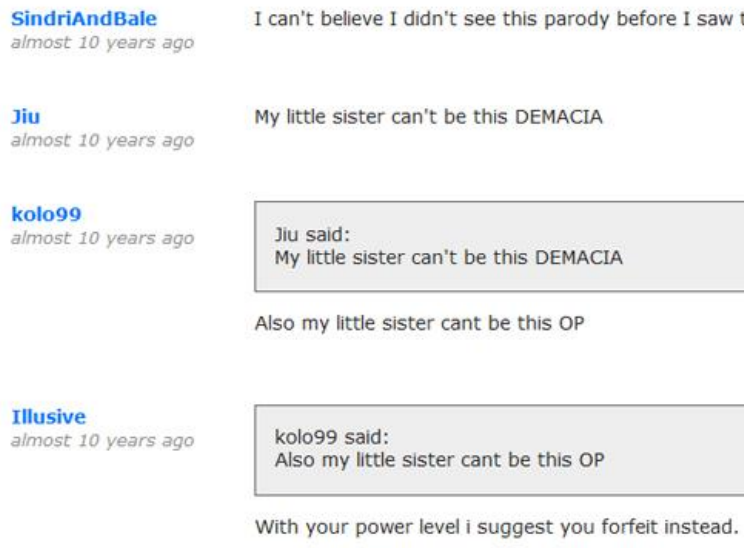

With your power level i suggest you forfeit instead.

Fonte: Reddit (2020) ${ }^{106}$.

A segunda função destacada é a de anexação de imagens, vídeos, áudios, emojis e demais recursos multimídias, como descrito por Komesu (2009). Para além da possibilidade de anexação de mídias em um comentário escrito, há também a variante, presente nos fóruns de imagens como Rule 34 e Danbooru em que posts de imagens multimídia permitem que descrições escritas sejam anexadas junto à postagem, como um comentário do próprio autor da postagem.

Figura 32 - Exemplo de post multimídia com comentário escrito.

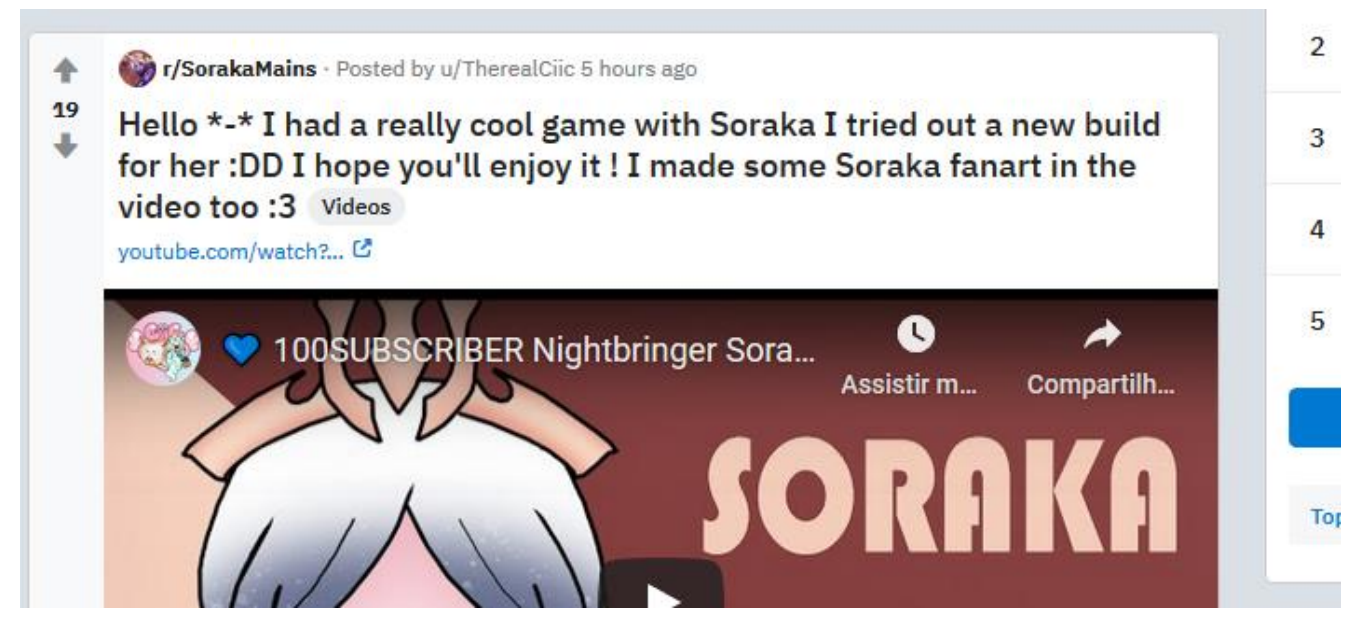

Fonte: Reddit $(2020)^{107}$.

106 Disponível em: <https://danbooru.donmai.us/posts/777830>. Acesso em: 10 mar. 2021.

107 Disponível em: <https://www.reddit.com/r/SorakaMains/comments/jf24mi/hello_i_had_a_really_cool_game_with _soraka_i/>. Acesso em: 10 mar. 2021. 
Figura 33 - Exemplo de gif no meio de um comentário.

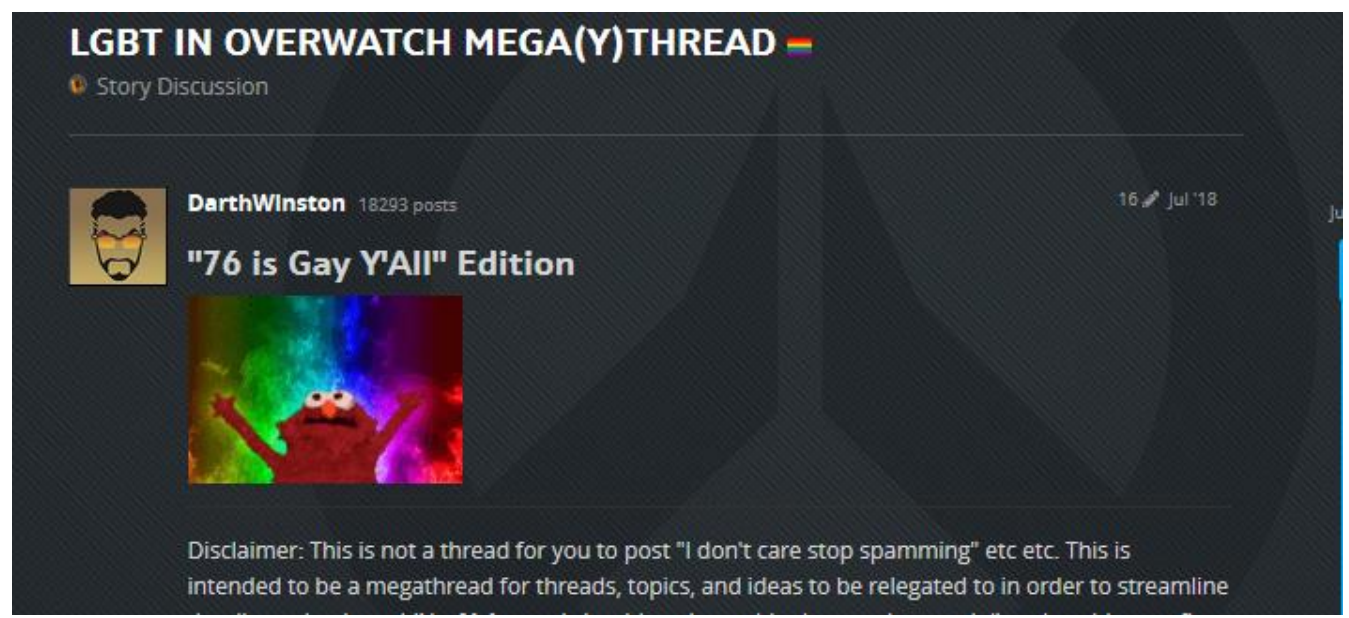

Fonte: Blizzard $(2020)^{108}$.

Em relação à característica escrita, o meio do fórum de internet, é descrito por Pessoa de Barros como um meio complexo entre a fala e a escrita, pois "exemplificam boa parte desses pontos intermediários entre a fala e a escrita ideais, nos três aspectos observados (...): as características temporais, espaciais e actoriais do discurso falado e escrito." (BARROS, 2015b, p.15).

Segundo Pessoa de Barros, o discurso da internet apresenta-se num meio-termo entre a informalidade, concomitância e incompletude da fala, e a formalidade, não-concomitância e completude da escrita, aproveitando-se dos efeitos de cada um no momento desejado ${ }^{109}$. Esta complexidade faz com que as categorias de espaço, tempo e pessoa se tornem menos marcadas na enunciação do discurso na internet: o autor é um alguém, mas que pode não ser este alguém. As enunciações estão todas no mesmo espaço, mas são feitas por sujeitos que podem não possuir

108 Disponível em: <https://us.forums.blizzard.com/en/overwatch/t/lgbt-in-overwatch-megaythread/159835/4>. Acesso em: 10 de mar. 2021.

${ }^{109}$ Pode-se observar, porém, que o tamanho dos textos em cada comentário tende a exercer certa influência na dinâmica entre formal-escrita e informal-fala: quanto mais extenso o comentário, mais inclinado às convenções da escrita formal ele se torna, com a informalidade estando mais presente nos comentários mais concisos. 
contato entre si. As enunciações possuem a ordem temporal de uma conversa, mas podem ser acessadas a qualquer momento.

Em relação ao enunciatário, este pathos coletivo que representa toda a comunidade de fãs e jogadores, há também traços de desconfiança. Pois quando se fala à totalidade, se reforça a dimensão polêmica dos valores da enunciação: logicamente, tanto um sujeito antagônico quanto um sujeito adjuvante fazem parte da totalidade de tal comunidade. A partir disso, o sujeito da enunciação vê-se livre para se dirigir à comunidade, se valendo da ambiguidade entre fala e escrita, descrita no parágrafo anterior: Um enunciador pode discursar contra um julgamento do qual se diz vítima, sem precisar a pessoa, o espaço ou o momento ao qual se refere, apenas contando com convenções aceitas por pelo menos parte de tal comunidade, porém atribuindo tal pathos a toda a comunidade.

No capítulo seguinte, esta pesquisa analisará alguns exemplos que detalham as dinâmicas que envolvem tais enunciadores e enunciatários do fórum. A seguir, entraremos em detalhes a respeito da sanção veridictória, presente no final do percurso narrativo, cuja ausência na análise de $L O L$ e Overwatch no capítulo anterior demanda um olhar mais atento.

\subsection{A sanção no ambiente de fórum}

A sanção oferecida às enunciações dos perfis pode vir de duas formas principais: quantitativa/reduzida, e dialógica/extensa. A primeira é fruto da natureza estatística dos fóruns, da internet gerida pelo big data. Há, na grande maioria dos sites de fóruns aqui levantados como corpus de análise, ferramentas similares ao Curtir, onde os perfis que acessam à thread podem sancionar positivamente (e as vezes, negativamente) o comentário selecionado. No caso dos fóruns para publicação e comentário de peças artísticas (como o Danbooru ou o Rule34) tais curtidas são aplicadas à arte que origina a thread, neste caso se aproximando mais do modelo de autor proposto por Discini em seu estudo Blog e campo de presença.

Figura 34 - Colagem exemplificando a sanção qualitativa, assinalada em vermelho. Em sentido descendente: Reddit, Youtube, Fórum de Overwatch e Danbooru. 
pricet803 14 hours ago

How is this only a highlight?

$45 \div$ Reply Share Report Save

Detective Salsa 1 ano atrás

I prefer overwatch over fornite anytime

3 mil 91 RESPONDER

- Ver 93 respostas

MareHeroes 17281 post5

You just said it yourself, probably the same designer that came up with Doomfist. Lul.

3 Replies $v$

Information

ID: 3933669

Date: about 8 hours ago

Size: 417 KB $(1125 \times 1125)$

Source: pixiv.net/artworks/67302295 »

Rating: Safe

Score: 4

Favorites: 6

Status: Active

Fonte: imagem nossa, adaptada de Reddit, Youtube, Gamepedia, Danbooru ${ }^{110}$.

Este tipo de sanção, por ser quantitativa e não necessitar de nenhuma interpretação textual complexa, costuma ser encontrado mais facilmente do que a sanção do tipo dialógica. Por este motivo, alguns dos sites (como o Youtube) permitem que os usuários filtrem todos os posts de uma thread, mostrando primeiro os posts com mais curtidas, portanto com a sanção quantitativa mais positiva. Ainda que estas sanções quantitativas não sejam o foco de análise desta pesquisa, vale apontar que sua existência guia parte das ações dentro destes fóruns, pois ainda sim validam, de forma simples, as enunciações e consequentes percursos sugeridos. Um exemplo desta afirmação

${ }^{110}$ Disponível em: <https://www.reddit.com/r/Overwatch/comments/gtbove/ive_been_called_i_must_answer_always />,<https://www.youtube.com/channel/UCJyTWgKoUjyFIlhUmIOGHuw/featured>,<https://us.forums.blizzard.com /en/overwatch/t/echo-is-cancer-pls-fix/509127>, <https://danbooru.donmai.us/posts/3933669>. Acesso em: 10 mar. 2020. 
pode ser visto na prática de, ao receber uma grande quantidade de sanções positivas da comunidade do fórum, um perfil editar sua própria postagem para agradecer tal sanção.

Figura 35 - Exemplo do processo e "edição" da enunciação enunciada como agradecimento à uma sanção positiva.

Parker Yancey 1 ano atrás (editado)

Ah, the French and British are at it again...

edit- I come back a year later to my most liked youtube comment ever XD thanks yall

5,9 mil $\quad$ q RESPONDER

- Ver 42 respostas

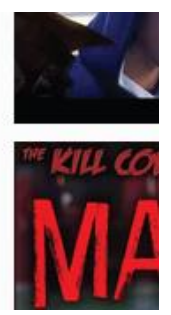

Fonte: Youtube (2020) $)^{111}$.

Na imagem acima, é um comentário referente a uma animação ${ }^{112}$ que apresenta um combate entre duas personagens de Overwatch, a inglesa Tracer e a francesa Widowmaker. No comentário, o perfil enuncia que "Ah, os Franceses e os Ingleses começaram novamente...", em referência ao histórico que ambos os países possuem de combaterem entre si durante o período medieval europeu - neste sentido a guerra dos Cem Anos (1337-1453) é um exemplo famoso do antagonismo entre os países, naquela época. Ao receber cerca de 5,9 mil curtidas no comentário, o perfil edita este, adicionando que "Edição- Eu voltei aqui um ano depois para meu comentário de Youtube mais curtido de todos os tempos XD obrigado a todos"

Na sanção quantitativa, especialmente diante de um objeto complexo e pluri-isotópico como o caso desta pesquisa, não há como analisar qual é o percurso sancionado positivamente. Quando um perfil faz uma piada relacionando uma isotopia do jogo de videogame com um acontecimento do mundo real, não é possível identificar se a sanção quantitativa recebida é uma sanção à relação proposta, à piada feita, ao ethos do perfil que enuncia ou mesmo ao conjunto.

Diferente do tipo quantitativo, a sanção dialógica é dada na interação discursiva entre os perfis engajados numa thread, onde é possível analisar as estratégias de validação do discurso, bem

${ }^{111}$ Disponível em: 〈https://www.youtube.com/watch?v=U130wnpi-C0〉. Acesso em: 10 mar. 2021.

112 PLAY OVERWATCH. Overwatch Animated Short | Alive. Youtube. Disponível em: <https://www.youtube.com/ watch?v=U130wnpi-C0>. Acesso em: 18 jun. 2020. 
como quais isotopias e valores são mobilizados. Portanto, esta pesquisa buscará se fixar nas sanções e interações dialógicas e qualitativas, que permitem que se veja melhor a construção e manipulação dos valores em busca do estabelecimento de veridicções.

\subsection{0 meme nos fóruns}

Como observado no item anterior, imagens, vídeos e demais produções multimídia não raramente acompanham os comentários escritos, feitos pelos perfis nos fóruns. Para os usuários que não são habituados com o universo do jogo, ou sequer com a dinâmica de fóruns digitais como um todo, acompanhar as discussões pode se mostrar um tanto quanto difícil. Um dos motivos para tal é o uso intenso de Tecnoletos, descritos por Galli (2009) e discutidos já anteriormente neste texto.

Outro elemento é a natureza intensamente referencial que se apresenta nestes espaços. Discini (2015) propõe que o espaço de blog é como "Um sistema concomitantemente homogêneo, fechado em si, e heterogêneo, aberto ao mundo" (DISCINI, 2015, p. 115). A intensa circulação dos temas e figuras dos jogos $L O L$ e Overwatch se choca com temas e figuras advindos do mundo das coisas, onde circulam seus jogadores.

A fim de observar melhor esta interação excessiva de diversas linguagens e figuras, esta pesquisa propõe analisar em maior detalhe um elemento que costuma congregar em si estes diferentes temas e figuras: o Meme.

No célebre livro intitulado O Gene Egoísta, publicado pela primeira vez em 1976, Richard Dawkins propôs uma leitura sobre a teoria evolutiva de Darwin, considerando os genes os principais responsáveis pela evolução das formas de vida. Segundo o autor, três fatores seriam definidores para que, nos processos de meiose que geram descendentes, os genes pudessem se duplicar nos novos corpos, suplantando os demais códigos genéticos concorrentes: longevidade (genes que manteriam sua configuração intacta por mais tempo), fecundidade (genes que pudessem gerar o número máximo de cópias) e fidelidade (genes que produzissem o menor número de cópias 
com mutações). A partir de tais princípios, o autor postula que os genes possuem a tendência a promover ações “egoístas”, visando sua própria sobrevivência e replicação.

Ainda que o foco central do livro, a biologia genética e, em certa medida, a sociologia, uma das postulações de Dawkins é de grande importância para a área da semiótica, especialmente nos estudos semióticos que observam as novas tecnologias. No capítulo 11 de seu livro, o autor postula que, equivalente à unidade biológica gene, deve ser considerada a existência de uma unidade cultural, que opera de maneira similar. A esta unidade o autor nomeia "meme", a partir da raiz grega de imitação mimeme e da palavra francesa para memória, même. Segundo o autor:

Exemplos de memes são melodias, ideias, slogans, as modas no vestuário, as maneiras de fazer potes ou de construir arcos. Tal como os genes se propagam no pool gênico saltando de corpo para corpo através dos espermatozoides ou dos óvulos, os memes também se propagam no pool de memes saltando de cérebro para cérebro através de um processo que, num sentido amplo, pode ser chamado de imitação. (DAWKINS, 2007, p.330).

O termo proposto por Dawkins acabou por ser incorporado para descrever as manifestações características da internet, e que recebem análises semióticas nos últimos anos, dada sua grande difusão e crescente importância no universo cultural globalizado e na Manifestação Cultural Dominante.

Na proposta do autor, a eficácia de um meme dependeria de três fatores, similares aos propostos para a eficácia da replicação genética:

- $\quad$ Longevidade: Segundo Dawkins, a longevidade de um meme parece ser o elemento de menor impacto. Se for analisada a grande rotatividade que caracteriza o ambiente digital, a estabilidade de uma manifestação específica de um elemento memético de fato possui pouco alcance.

- $\quad$ Fecundidade: A fecundidade é definida pela força da difusão que tal meme possui. O autor considera que a importância deste quesito significa a aceitação ou adequação de determinado meme em uma sociedade. 
- $\quad$ Fidelidade: Diz respeito a capacidade de um meme de não gerar cópias "modificadas". Inicialmente, Dawkins, Marino e outros especialistas consideram que a unidade memética pressupõe que, a cada nova transmissão, o meme é alterado e editado.

A questão da fidelidade solicita que se preste mais atenção à proposta original, de Dawkins: segundo o autor, o conceito de "gene" e, por consequência, de "meme" é contextual:

Recorri ao mesmo truque verbal que empreguei no capítulo 3. Lá, dividi o "complexo de genes" em unidades genéticas grandes e pequenas e em unidades dentro de outras unidades. O "gene" foi definido não como uma forma rígida e absoluta, e sim como uma unidade de conveniência, uma extensão de um cromossomo com um grau de fidelidade de cópia suficiente para servir como uma unidade viável de seleção natural. Se uma única frase da Nona Sinfonia de Beethoven for marcante e memorável o suficiente para ser abstraída do contexto de toda a sinfonia e usada como vinheta de abertura de uma estação emissora de rádio europeia irritantemente incômoda, então, nesse sentido, ela merece ser considerada um meme (DAWKINS, 2007, p. 335).

O semioticista italiano Danielle Marino, em seu artigo “Qual semiótica da propagabilidade: uma abordagem sistemática de memes e virais de Internet”, de 2018, observa que, num primeiro momento, as pesquisas meméticas e linguísticas que envolviam os memes, e os memes como fenômenos cultural da internet, não dialogavam entre si, em função de uma não-sistematização do estudo memético. Apesar da ausência de sistematização, o autor observa que "Não obstante a crítica acima. A noção de meme tem sido empregada em estudos semióticos como sinônimo de 'ideia, signo ou texto eficaz e difundido'; ou seja, tem sido empregada metaforicamente, sem endosso da ideologia holística do paradigma memético" (MARINO, 2018, p. 11).

Marino então propõe a atribuição de um valor heurístico para o valor dos memes dentro do ambiente digital. Para tal resultado, o autor faz uso de alguns trabalhos na área da semiótica e tecnologia digital, que corroboram uma leitura do meme mais próxima da que Dawkins havia originalmente proposto: uma unidade de sentido reprodutível dentro de um texto. Três autores (Umberto Eco, Lucio Spaziante e Gérard Genette) são referenciados por Marino para a estruturação deste modelo, sendo suas contribuições as seguintes:

- $\quad$ Sistemas Textuais: Propostos pelo crítico literário Gérard Genette no livro Palimpsestos: A literatura de segunda mão, estes são sistemas de "relações 
transtextuais, que enumerarei numa ordem crescente de abstração, implicação e globalidade" (GENETTE, 2010, p. 14). São eles:

1. Intertextualidade: Um texto que faz referência direta e transcrita a outros textos, podendo ser apresentado na forma de referência, citação ou cópia (no sentido de plágio).

2. Paratextualidade: Já citado anteriormente nesta pesquisa, pois foi utilizado nas pesquisas de Eco (2017), são textos assessórios, como notas de rodapé, introduções, críticas de um texto, avaliações dentre outros.

3. Metatextualidade: Um texto que faz um comentário relativo a outro texto. Difere da intertextualidade pois não é uma transcrição direta de outro texto, mas um comentário.

4. Hipertextualidade: De acordo com o autor, "Entendo por hipertextualidade toda relação que une um texto B (que chamarei de hipertexto) a um texto anterior (que, naturalmente, chamarei hipotexto) do qual ele brota de uma forma que não é a do comentário". (GENETTE, 2010, p. 18). É um texto da paródia, pastiche, charge, ou transposição.

5. Arquitextualidade: Um texto que possui relações não-explícitas com outros textos, como o gênero ou estilo, que unem textos sob este "rótulo" comum.

- $\quad$ Reinterpretação de um texto: O semioticista Lucio Spaziante, em seu Sociosemiotica del Pop (2007), propõe uma análise sociosemiotica, com foco na música, mas considerando também outras linguagens que possam se encaixar no rótulo de “'culturapop', que, portanto, envolve o cinema, videogames, televisão, Internet, moda, quadrinhos, esportes e música, estão entre as principais fontes que compõem a imaginação contemporânea" (SPAZIANTE, 2007, p. 12 - tradução nossa). Para o autor, a característica participativa dos fenômenos pop, que mobilizam valores "míticos e coletivos" (p. 12 - tradução nossa) levam a três práticas de réplica de textos preexistentes: 
1. Sampling: Chamado também de Reinterpretação Apropriativa, é a extração de um texto pré-existente. Pode aparecer em nível estrutural ou em nível referencial.

2. Remixing: Também chamado de Reinterpretação Manipulativa, é considerado por Marino (2018) como o hipônimo de um sampling; enquanto neste há a apropriação de um trecho de outro texto, no caso do remixing há uma modificação/reapropriação de todo um dado texto.

3. Remaking: Uma reinterpretação propriamente dita. A recriação de um texto preexistente, sem relação com sua forma original de expressão ou meio, como uma adaptação de um texto para outro meio ou uma imitação.

- $\quad$ Desconjuntividade: No livro Seis passeios pelos bosques da ficção (2017), Umberto eco chama de "desconjuntividade" um dos fatores responsáveis pelo sucesso cult de Casablanca, Hamlet, a Bíblia e a Rocky Horror Picture Show. Tal desconjuntividade se apresenta quando uma obra possui trechos desconexos, pedaços, imagens e frases da obra que podem ser replicadas de maneira mnemônica, como um kit para montar arquétipos que potencializa sua propagabilidade. Segundo o autor, que metaforiza o processo de leitura de ficção como a entrada num bosque "Para se tornar sagrado, um bosque tem que ser emaranhado e retorcido como a floresta dos druidas, e não organizado como um jardim francês" (ECO, 2017, p. 134).

Marino porém apresenta uma discordância a respeito do conceito de meme de Dawkins: para o autor "A ideia é que práticas textuais identificadas por termos como 'viral' e 'meme' devem sua eficácia não tanto a mecanismos de mimetismo ou contágio, mas à sua capacidade de estimular a participação dos usuários ou, em outras palavras, ativar sua agência" (MARINO, 2018, p. 17).

Para o autor, os memes da internet são textos similares aos textos ergódigos (Aarseth, 1997), que demandam a agência dos usuários/leitores, não sendo adequada a metáfora da "contaminação" neste caso. Marino então faz referência ao pesquisador de cultura contemporânea Henry Jenkins (mais especificamente em seu livro Cultura da Conexão, escrito em parceria com Joshua Green e Sam Ford) e seu conceito de propagabilidade. Para os autores: 
A "propagabilidade" se refere ao potencial - técnico e cultural - de os públicos compartilharem conteúdo por motivos próprios, às vezes com a permissão dos detentores dos direitos autorais, às vezes contra o desejo deles. (...) A "propagabilidade" se refere aos recursos técnicos que tornam mais fácil a circulação de algum tipo de conteúdo em comparação com outros, às estruturas econômicas que sustentam ou restringem a circulação, aos atributos de um texto de mídia que podem despertar a motivação de uma comunidade para compartilhar material e às redes sociais que ligam as pessoas por meio de troca de bytes significativos (JENKINS; FORD; GREEN, 2014, p. 26-27)

Tomando tais princípios como base, Marino propõe uma leitura de continuиm memético a respeito destes memes, estruturada no gráfico abaixo:

Figura 36 - Modelo do continuum memético proposto por Marino (2018).

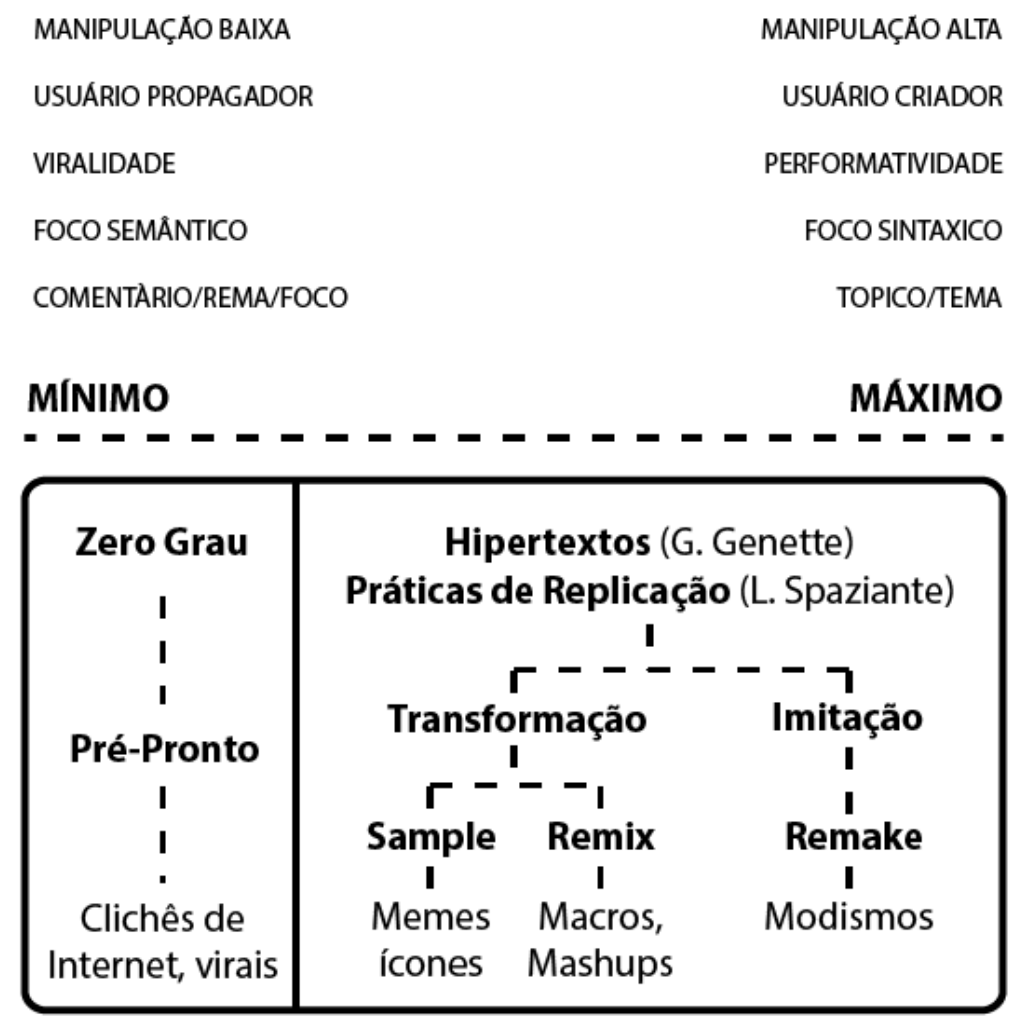

Fonte: imagem nossa, adaptada de Marino (2018)

Neste modelo de continuum memético, há uma gradação, pensando na propagabilidade descrita por Jenkins, Ford e Green, em que um elemento da manifestação do meme pode pender para o lado da agência/propagabilidade mínima do usuário (lado esquerdo do gráfico) ou para o lado da máxima agência/propagabilidade do usuário (lado direito do gráfico). 
Do lado esquerdo, onde a agência/propagabilidade do usuário diminui, a tendência é que o meme receba pouca ou nenhuma manipulação, e o efeito cômico não precise ser sublinhado, como é o caso dos vídeos virais da internet. Nestas condições o usuário é muito mais um agente propagador do que criador, se aproximando mais do elemento virológico originalmente proposto por Dawkins (2014).

Do lado direito, onde a agência/propagabilidade do usuário aumenta, o meme recebe sucessivas manipulações de usuários que se tornam criadores e cocriadores. Aqui, ao invés de comportamento de vírus, os usuários performam na construção do meme, assumindo e manipulando seus valores.

Dentro deste continuum, podemos encontrar as práticas de replicação de Spaziante (2007), à medida que a participação do usuário na criação do meme aumenta: partindo da participação mínima do meme pré-pronto (o exemplo dos vídeos virais da internet) temos a prática de Samples (Meme Ícone), depois os Remixes (Alterações no meme ícone, que gera uma série de memes com o mesmo tema), e por último, os Remakes (Quando os usuários criam novos textos comentando ou participando dos memes).

Pensando nas relações textuais de Genette (2010), todos estes memes são hipertextos, cabendo aos Samples e Remixes a relação hipertextual de transformação, enquanto o Remake é um hipertexto de transformação.

O que torna tal sistema de continuum memético interessante para a presente pesquisa é seu caráter estrutural. Segundo as conclusões do autor:

Para resumir, um meme de Internet típico - categoria que constitui, de facto, o melhor e principal exemplo de um texto propagável - apresenta um "gancho sintático" (uma estrutura modular, fórmula e modelo) e um "gancho semântico" (um elemento marcante, um punctum, geralmente um erro que se sobrepõe a um núcleo semântico básico). A viralidade ou propagabilidade de memes da internet baseiam-se nessas duas características e em seu equilíbrio. Um atua sobre a agência dos usuários, outra sobre o engajamento deles. (MARINO, 2018, p. 33).

Para Marino, este elemento sintático é o conjunto de elementos que "permitem o engajamento de usuários em operações de bricolagem de acordo com diferentes graus de 
intervenção" (p. 33) enquanto o elemento semântico é um punctum ${ }^{113}$ marcante. Tal punctum é um termo usado por Roland Barthes em seu derradeiro livro A Câmara Clara (2015), a respeito do processo humano de criar e capturar imagens. Para o autor, quando observa o conceito de punctum na fotografia, a descrição é a seguinte:

Neste espaço habitualmente unário, às vezes um detalhe me atrai. Sinto que basta sua presença para mudar minha leitura, que se trata de uma nova foto que eu olho, marcada a meus olhos por um valor superior. Esse "detalhe" é o punctum (o que me punge). (...) Com muita frequência, o punctum é um 'detalhe', ou seja, um objeto parcial. Assim, dar exemplos de punctum, de certo modo, entregar-me. (BARTHES, 2015, p. 41-42).

Barthes apresenta este punctum em oposição a outro conceito presente na apreciação de uma fotografia, o studium. Este é um sentimento moderado, muito menos intenso e cortante do que um punctum, e que é de modo geral mais frequente. Para Barthes, o studium possui um caráter de conformismo:

O studium é uma espécie de educação (saber e polidez) que me permite encontrar o Operator, viver os intentos que fundam e animam suas práticas, mas vive-las de certo modo ao contrário, segundo meu querer de Spectator. Isso ocorre um pouco como se eu tivesse de ler na fotografia os mitos do Fotógrafo, fraternizando com eles, sem acreditar inteiramente neles. Estes mitos visam evidentemente (e para isso é que serve o mito) reconciliar a Fotografia e a sociedade, dotando-a de funções, que são para o Fotógrafo outros álibis. (BARTHES, 2015, p. 31)

De um lado, há um studium de alinhamento de valores e visão social, do outro, há um punctum intenso e pessoal. Segundo Marino, este punctum:

no caso de um meme, que é um texto derivado, o erro existente no texto original é selecionado, posto sob um holofote e propagado. O 'erro' do texto fonte é o gancho semântico que atrai a atenção do usuário, tornando o texto suscetível à seleção e disseminação meméticas. (MARINO, 2018, p. 32)

Portanto, dentro dos elementos semânticos do modelo memético de Marino, o studium representa a compreensão dos textos-contextos de um elemento memético, enquanto o punctum se

\footnotetext{
113 Punctum é um termo cunhado por Roland Barthes em seu livro A Câmara Clara, que define um elemento marcante que atrai a atenção pessoal do observador, para além das convenções sociais. Descrito em detalhes no glossário no fim da dissertação.
} 
mostra como um elemento marcante e "pessoal" para o leitor, uma espécie de verdade descoberta, e que por isso convida o usuário a propagá-la e comentá-la. E tanto studium quanto punctum semânticos são representados, no nível discursivo, pelas figuras e temas. Pessoa de Barros nos lembra que "As figuras semânticas do discurso, conforme foi explicado, procuram, essencialmente, criar a ilusão de realidade.” (BARROS, 1988, p. 154).

Para que se compreenda as estratégias de veridicção, esta pesquisa propõe que se observem e enumerem os elementos estruturais sintáxicos de apropriação e alteração dos textos nos espaços dos fóruns, a partir do modelo de Marino e das gradações propostas por Genette, Spaziante e Eco.

Após tal levantamento, que se observe mais profundamente como se apresentam as figuras e temas observadas no capítulo 2 (a análise semiótica dos jogos), observando quais padrões se apresentam na manipulação de tais valores.

\subsection{A sintaxe memética nos fóruns}

Uma característica marcante dos fóruns presentes no corpus desta pesquisa é sua variedade de linguagens, com elementos visuais, textuais, audíveis entre outros. Estes elementos constituem o que, na semiótica, se considera como a forma da expressão, onde é possível ver o resultado dos jogos semióticos, ocorridos no nível fundamental e narrativo, manifestados.

Segundo Waldir Beividas, o momento em que se observa tais linguagens multimídia é "o instante (metodológico) em que a forma do conteúdo se deixa amoldar, por assim dizer - face à 'solidariedade' (função semiótica) que mantém com a forma da expressão - às coerções que esta última carrega, dada a natureza da matéria significante, ou seja da substância da expressão" (BEIVIDAS, 2015, p. 84). Como a forma da expressão acaba por interferir no conteúdo proposto, esta pesquisa dedicará este item à análise de uma lista de linguagens comumente encontradas nos fóruns analisados.

A lista a seguir se apresenta apenas como uma interpretação da variedade de manifestações discursivas dentro dos espaços de fórum do corpus desta pesquisa, a partir do modelo de trabalho de Marino (2018) a respeito do continuum memético, propondo uma maior compreensão da forma 
da expressão dos fóruns. Tal levantamento não intenta qualquer utilidade pré-estabelecida fora do contexto desta análise.

\subsubsection{Imagens meméticas}

O modelo do continuum memético de Marino foi desenvolvido tendo este tipo de objeto como corpus de análise, e esta pesquisa não vê a necessidade de adequar tal método de análise ao seu próprio corpus, pois todos os exemplos abordados por Marino em seu modelo possuem equivalentes dentro dos fóruns sobre $L O L$ e Overwatch. Esta pesquisa portanto se limitará a apresentar alguns exemplos de cada tipologia.

Os samples costumam se apresentar, nos fóruns presentes neste corpus de pesquisa, similar ao conjunto de critérios observado por Marino no meme-token: uma imagem engraçada acompanhada de um texto na fonte impact. No exemplo dado abaixo, são comparadas as aparências de uma skin antiga da personagem Evelynn, de $L O L$, em relação à uma versão mais atual (novamente, observe-se que as figuras e valores presentes neste meme corroboram a "Manifestação cultural dominante", citada há alguns capítulos):

Figura 37 - Meme tipo Sample. 


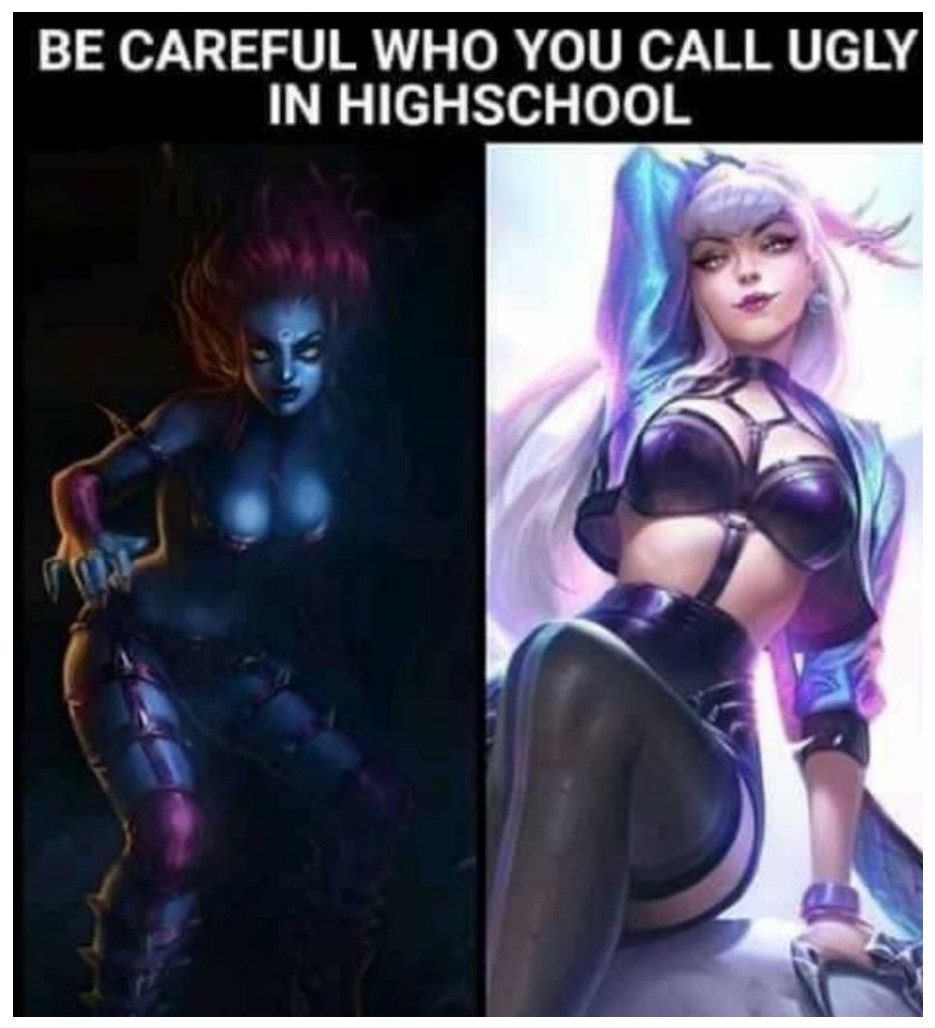

Fonte: Reddit $(2020)^{114}$.

As práticas de Remix possuem construções estéticas mais variadas, onde os elementos da imagem original são editados para criar o punctum memético. No caso do exemplo abaixo, a piada se refere ao lançamento de uma nova personagem, Seraphine, em $L O L$, que recebe uma "recepção" de um grupo de personagens que, dentro do jogo, possuem vantagens estratégicas em relação a ela. A sequência de imagem onde os rostos das personagens de $L O L$ estão inseridos são do anime japonês Jojo's Bizarre Adventure (2012).

Figura 38 - Meme tipo Remix.

114 Disponível em: <https://www.reddit.com/r/LeagueOfMemes/comments/jbtwt5/eve_is_a_bae/>. Acesso em: 10 mar. 2021. 


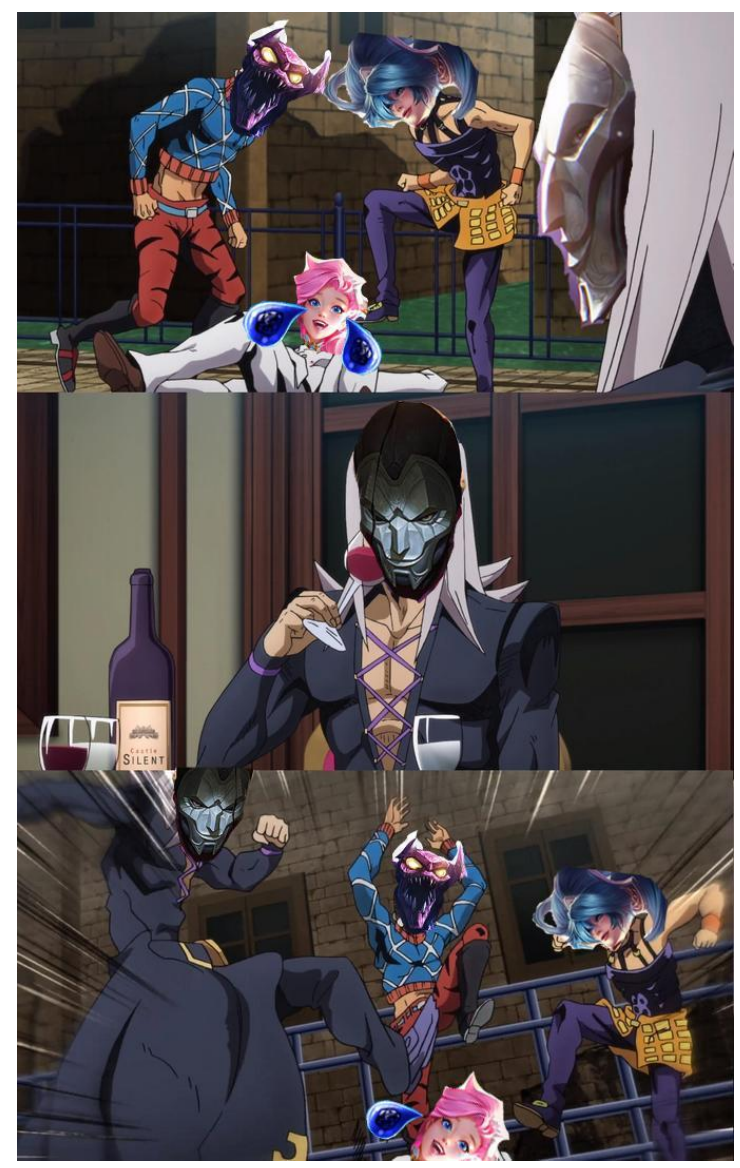

Fonte: Reddit $(2020)^{115}$.

As práticas de Remake, por fim, são textos imitacionais porque refazem um determinado texto preexistente. No exemplo abaixo, o "meme zero grau" (o elemento memético presente na imagem original, que não possui interferência dos propagadores) é o vídeo ${ }^{116}$ de apresentação da personagem Sombra, de Overwatch. Durante este vídeo (2016), após vencer sua adversária, Sombra a ridiculariza com um toque no nariz dela, enquanto fala a onomatopéia "Boop". Ao fim do vídeo, inclusive, a personagem Sombra repete o gesto, desta vez apontando o dedo na direção do espectador, para fazer o "Boop" no nariz deste.

Figura 39 - Meme zero-grau do "Boop" de Overwatch.

115 Disponível em: <https://www.reddit.com/r/JhinMains/comments/jbvkkt/welcome_to_summoners_rift/>. Acesso em: 10 mar. 2021.

116 PLAY OVERWATCH. Overwatch Animated Short | Infiltration. Youtube. Disponível em: <https:// www.youtube.com/watch?v=Og5-Pm4HNII>. Acesso em: 18 out. 2020. 


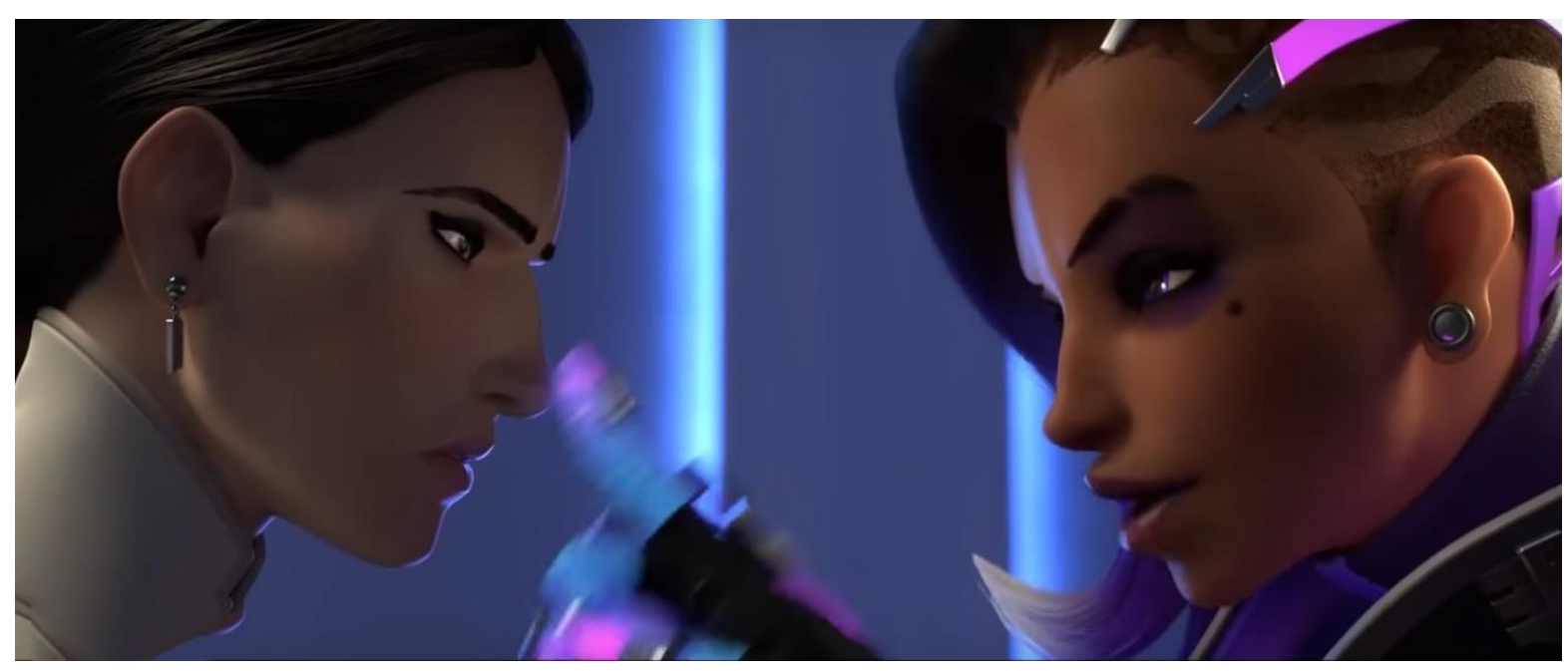

Fonte: Blizzard (2020) ${ }^{117}$.

Criou-se em torno do "Boop" de sombra uma série de memes de Samples e Remixes ${ }^{118}$, que por sua vez evoluíram para diversos Remakes, listados abaixo:

Figura 40 - Memes do tipo Remake.

${ }^{117}$ Disponível em: < https://www.youtube.com/watch?v=Og5-Pm4HNII\&t=6s>. Acesso em: 10 mar. 2021.

${ }^{118}$ MOUSTACHE SRL. Overwatch - (Sombra) Boop On Me [Take On Me Parody]. Reddit. Disponível em: <https://www.reddit.com/r/Overwatch/comments/5cgcjb/Overwatch_sombra_boop_on_me_take_on_me_parody/>. Acesso em: 18 out. 2020. 


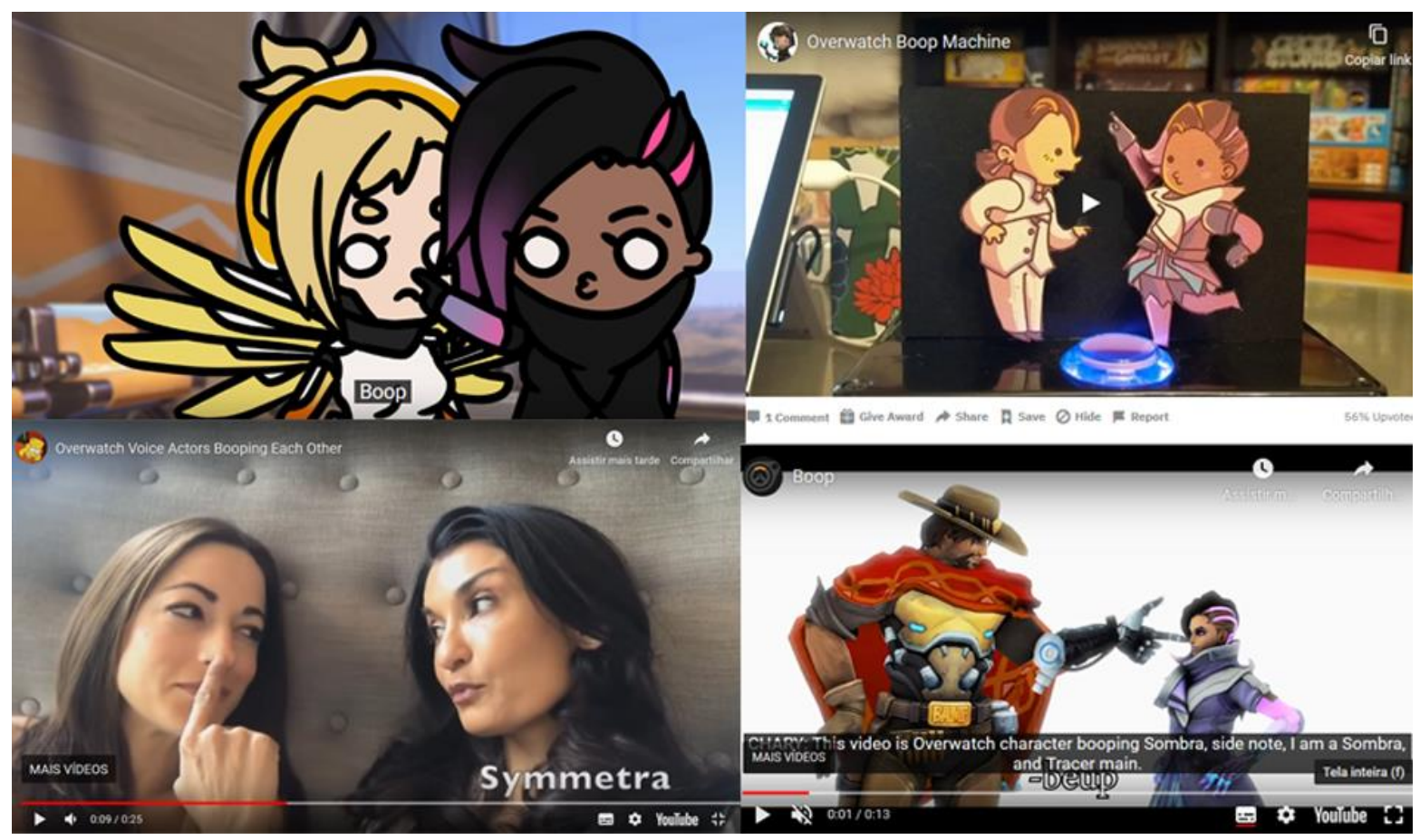

Fonte: Youtube (2020) e Reddit (2020) ${ }^{119}$.

A partir destes exemplos, esta pesquisa considera adequado que a metodologia desenvolvida por Gabriele Marino (2018) seja aplicada aos fóruns que compõe o corpus deste estudo. Além das múltiplas ocorrências de Samples, Remixes e Remakes que podem ser encontradas, o elemento de propagabilidade que permeia o continuum memético permite que sejam identificadas algumas diretrizes na multiplicidade de textos que são utilizados pelos perfis de fóruns em suas construções veridictórias.

\subsubsection{Narrativas/Fanfics}

Fanfic é um neologismo criado a partir da palavra "fan fiction", ou seja, ficção de fãs. A definição deste tipo de texto dentro do escopo desta pesquisa será baseada nos estudos da

${ }^{119}$ Disponível em: <https://www.youtube.com/watch?v=y1WqcXquRtI\&feature=emb_rel_end >, <https://www.reddit. com/r/Overwatch/comments/7kgb3z/overwatch_boop_machine/>, <https://www.reddit.com/r/Overwatch_Memes/ comments/7bzcaj/overwatch_voice_actors_booping_each_other/>, 〈https://www.reddit.com/r/Overwatch/comments/ 8ygjw1/humor_sombra_boop/>. Acesso em: 10 de mar. 2021. 
professora de literatura Anne Jamison, autora do livro Fic: por que a fanfiction está dominando o mundo (2017).

Segundo a autora, uma fanfic, em sentido geral, pode ser considerada como um "uma escrita que continua, interrompe, reimagina, ou apenas faz alusão a histórias e personagens que outras pessoas já escreveram" (JAMISON, 2017, p. 31). Porém, a fanfic dentro do corpus desta pesquisa possui uma particularidade: a sua relação com a comunidade onde é apresentada:

O que chamamos de fanfiction hoje é outra coisa, no entanto: não se trata apenas de escrever histórias sobre personagens e mundos existentes - é escrever essas histórias para uma comunidade de leitores que já querem lê-las, que querem conversar sobre elas e que podem estar escrevendo, também. (JAMISON, 2017, p. 49)

Ainda que a escrita deste tipo de texto tenha se popularizado com o desenvolvimento do computador e da internet, Jamison apresenta em seu livro diversas formas de escrita seculares que possuem estreita semelhança com a prática atual de fanfic. Em 1614, Afonso Avellaneda escreveu uma continuação de Dom Quixote à revelia do conhecimento de Miguel de Cervantes. Sir Walter Scott, autor de Ivanhoe (1819) teve sequências não-oficiais de seus trabalhos publicados, desde Willian Thackeray (1850) a Christopher Vogler (2006).

Em suas origens, a atividade de escrever versões próprias de universos conhecidos sempre foi vista como uma espécie de "treino" para escritores, tendo sido praticado por Willian Thackeray, Emily Brönte e J.M. Barrie. Porém, é a partir do início do século XX que tal atividade começou a ser relacionada mais fortemente com os fãs de determinados universos culturais. Um dos primeiros fandoms reconhecidos na mídia ocidental, e que se assemelha com as práticas atuais, é o que cerca o universo de Sherlock Holmes, de Arthur Conan Doyle.

Com a democratização dos meios de divulgação de textos e discursos, diversos fãs expandiam suas interações e seus trabalhos dentro da comunidade, de acordo com os meios disponíveis em sua época: O fandom contemporâneo de Sherlock Holmes fez suas fanfics principalmente por livros, nos anos 70 o fandom de Jornada nas Estrelas o fazia por meio revistas impressas manualmente, chamadas zines, compartilhadas em convenções e pelo correio. Nos anos 80-90, o fandom de Twin Peaks e Arquivo $X$ reunia seus fanfics no pioneiro sistema de fóruns Usenet, enquanto após os anos 2000, os fandoms de Harry Potter e Crepúsculo se reuniam, agora 
em proporções globais, em redes sociais como Facebook ou Twitter, bem como em sites especializados como Archive of our Own e Fanfiction.net.

Segundo Jamison, um dos grandes motivadores da construção de fanfics por parte da comunidade de fãs é a insatisfação com o desenvolvimento canônico do universo. Seja por soluções polêmicas, ou por elementos que não são suficientemente explorados, "Usar a insatisfação como inspiração é uma estratégia comum e muito produtiva na fanfiction, mas também é uma das menos compreendidas por gente de fora" (JAMISON, 2017, p. 71)

Outro motivador comum para a criação de fanfics, este descrito por Ron Hogan, escritor em entrevistado de Jamison em seu livro, é a capacidade dos fãs de reconhecerem as estruturas narrativas nas histórias que acompanham. "cresci em um mundo de fic que me estimulou a passar mais tempo ligado profundamente às histórias que amava, descobrindo os elementos funcionais que as faziam funcionar”. (HOGAN, 2017, p. 117).

Para o escritor, a atividade de escrever fanfic é uma versão elaborada de jogos feitos por crianças:

Pode começar; como descrevi antes, quando tratamos as histórias com as quais crescemos não apenas como textos para serem lidos, ou filmes ou programas a serem assistidos, mas como brinquedos com os quais podemos brincar. Em alguns casos, este processo é facilitado pela existência de brinquedos reais; mesmo sem objetos físicos, no entanto, nossas imaginações podem tomar conta dos elementos das histórias e ajustá-los a nosso gosto - seja um pitaco simples aqui e ali ou o desenvolvimento de uma narrativa completamente nova. Alguns de nós simplesmente avançam para outro estágio, onde, em vez de extrair os resultados de nossa imaginação de brincalhona de dentro de nossas cabeças ao mover bonequinhos pelos nossos quartos ou pela mesinha de centro da sala de estar, nós os colocamos no texto. (HOGAN, 2017, p. 117).

Hogan e Jamison ainda pressupõem que o fenômeno da metatextualidade, onde histórias e personagens de universos distintos se encontram (algo chamado nos fandoms de crossover $^{120}$ ), pode ser visto também nestas práticas infantis de misturar personagens (ou bonequinhos) em narrativas.

\footnotetext{
120 Crossover é o termo que define uma narrativa onde dois ou mais universos fantasiosos pré-existentes são referenciados. Hipoteticamente, seria como se existisse uma história onde Sherlock Holmes se encontrasse com os três Mosqueteiros. Descrito em detalhes no glossário no fim da dissertação.
} 
A Metatextualidade se torna óbvia na prática da fanfic, pela própria definição descrita por Jamison, do texto que possui referências não-diretas a outro texto-universo. Porém, a metatextualidade muitas vezes pode vir acompanhada de relações intertextuais, quando uma passagem do texto-referência é repetida ipsis literis na fanfic (estratégia que dá ainda mais peso a mudanças propostas pelo autor em sua nova versão do intertexto original). Nas fanfics pode ser comum também que apareçam relações arquitextuais, pois é muito comum que fanfics sejam divididas em "tipos" de relacionamento, ou "intensidade" dos acontecimentos, como mostrado no exemplo abaixo:

Figura 41 - Exemplo de categorias existentes em fanfics.

Graphic Depictions Of Violence, Major Character Death, Lena "Tracer" Oxton, Angela "Mercy" Ziegler, Jesse McCree, Fareeha "Pharah" Amari, Soldier: 76 | Jack Morrison, Hana "D.Va" Song, Genji Shimada, Undisclosed Character(s), Crimes \& Criminals, Organized Crime, Alternate Universe - Modern Setting, LCBTQ Character, LCBTQ Themes, References to Depression, Mental Health Issues, Mental Instability, Soul-Searching, Feels, Weapons, References to Drugs, Alcohol Abuse/Alcoholism, Drug Abuse, Recreational Drug Use, Implied/Referenced Homophobia, Homophobia, Implied Relationships, Alternate Universe - Modern: No Powers, Alternate Universe - No Overwatch

"To let go of grief, one has to let go of the person that they were when the grief was caused. They have to change, they have to move on, and forget the past."

An AU set in a world without Overwatch. A young Lena Oxton fights through the process of finding herself, and is helped along by a few familiar faces. Her journey will not take her along the yellow-brick road to $\mathrm{Oz}$, though. Instead, Lena finds herself in the dark underbelly of her home, and in the presence in some of the most notorious criminals this side of the Thames.

Creator Chose Not To Use Archive Warnings, Soldier: 76 | Jack Morrison/Reaper | Gabriel Reyes, Soldier: 76 | Jack Morrison, Reaper | Gabriel Reyes, Original Female Character(s), Original Female Character(s) of Color, Original Male Character(s), soul play, disgustingly sweet fluff, nothing too explicit yet, Angst, relationship deteroriation, i guess, OCs Freeform, Light Angst, Alternate Universes

just a bunch of ficlets that I jot down when the mood strikes me. Multi pairings, multi fandoms.

Fonte: imagem nossa, adaptada de Archive of Our Own (2020) ${ }^{121}$.

Na imagem acima, categorias como Drug Abuse (Abuso de drogas), Angst (Angústia) indicam alguns dos elementos tímicos da fanfic, e categorias como "Soldier: 76|Jack Morrison / Reaper|Gabriel Reyes" Indicam quais serão os ships ${ }^{122}$ apresentados na história.

Dentro do continuum memético de Daniele Marino, as fanfics costumam se apresentar como Remakes e, em menor frequência, como Remixes. Esta afirmação se embasa nos levantamentos

${ }^{121}$ Disponível em: <https://archiveofourown.org/>. Acesso em: 10 mar. 2021.

122 Ships é o termo usado na comunidade para se referir a casais num universo ficcional. Descrito em detalhes no glossário no fim da dissertação. 
feitos por Jamison: Além da afirmação, citada no começo deste item, de que as fanfics são feitas para um público que deseja os acontecimentos e relacionamentos propostos neste tipo de texto, há valores de releitura presentes na fanfic:

Por mais diversas que as comunidades de fanfiction e sua escrita possam parecer, elas não se encaixam na imagem comumente atribuída aos escritores experimentais ou vanguardistas, e por uma boa razão. Vanguardas literárias tendem a atrair e ser descobertas por aqueles que já manifestavam um desgosto notável pelo status quo do entretenimento tanto literário quanto comercial. As comunidades de fanwriting desfrutam e consomem vorazmente a cultura comercial, a celebram, até quando desafiam e transformam seus produtos para os próprios propósitos, às vezes radicais. [...] Persuadidos pela presença de seus personagens favoritos, até os leitores menos aventureiros às vezes abraçam histórias apresentando sexualidades e gêneros alternativos, ou desfrutam de um material mais desafiador em termos estilísticos e temáticos do que teriam acesso de outra forma. Porém, a fanfiction é em sua maior parte motivada pelo amor àqueles mesmos elementos - narrativa e personagem -, que boa parte da escrita experimental do último meio século buscou questionar e criticar. (JAMISON, 2017, p. 36)

Marino propõe que "a segunda categoria sintática opera pela transformação (samples e remixes), enquanto a terceira opera pela imitação (remakes).” (MARINO, 2018, p. 28). Portanto um tipo de texto como a fanfic, que se apóia em um punctum serializado e que reencena os elementos célebres de sua forma original, é um tipo de operação similar aos remakes, ainda que, como Jamison aponta, haja em menor frequência exemplos mais experimentais, que se comportam à maneira de samples e remixes.

\subsubsection{Ilustrações}

Conceitos abrangentes, como "desenho" "pintura" e "ilustração" possuem muitas interpretações possíveis, bem como uma bibliografia extensa de estudos nas mais diversas áreas, com nomes como Rudolph Arnhein, Erwin Panofsky e Jacques Aumont. Como uma definição geral das imagens que analisaremos neste trecho, esta pesquisa opta pela definição do artista plástico cantonês Wucius Wong, em seu livro Princípios de forma e desenho (2001). Para o autor, o fato de o desenho ocupar funções que variam desde a ornamentação até o desenho técnico, faz desta linguagem algo que: 
constitui a melhor expressão visual possível da essência de "algo", seja uma mensagem, seja um produto. Para executar esta tarefa de forma acurada e efetiva, o desenhista deve procurar a melhor maneira possível em que este "algo" possa ser definido, feito, distribuído, utilizado e relacionado com o ambiente. Sua criação deve ser não somente estética mas também funcional, ao mesmo tempo que reflete e orienta o gosto de seu tempo. (WONG, 2001, p. 41).

Wong, como uma expressiva parcela de artistas que enveredam pelo caminho do ensino e pesquisa, guia suas pesquisas por uma linha majoritariamente formalista. Porém, como vemos na passagem acima, o autor admite a importância do que ele chama de "algo", que é o conteúdo, na terminologia semiótica.

No Princípios de forma e desenho, o autor discorre sobre as possibilidades pictóricas dos elementos de desenho (linha, ponto, volume etc.), visuais (formato, tamanho, cor etc.) e relacionais (direção, posição, gravidade etc.) que compõe uma imagem bidimensional analógica e digital. Mas admite a importância dos elementos não-subjacentes ao conteúdo e extensão de um desenho, como a "Representação: Quando um formato é derivado da natureza ou mundo feito pelo homem, ele é figurativo ou de representação" (WONG, 2001, p.44).," Significado: O significado está presente quando o desenho transmite uma mensagem" (ibid.)e "Função: A função está presente quando o desenho serve a um propósito" (ibid.). O autor decide por não abordar tais temas em seu livro, pois fogem ao seu escopo.

Ainda que a separação entre forma e conteúdo de um discurso seja uma estratégia para organizar análises semióticas, ambas as dimensões são constituintes do signo linguístico. Fernando Fraenza, artista plástico e semioticista argentino, afirma que a apreensão visual das formas pelo aparelho visual humano é fundamental na definição do que será o signo, tanto a nível individual quanto coletivo.

A partir de princípios postulados por Umberto Eco, David Marr e Noam Chomsky, Fraenza propõe que, pensando nos princípios do desenho de memória e do desenho de observação, a formação do referencial imagético de uma pessoa, bem como a "criação" de elementos , passem por uma estrutura de criação de sentido, representada a seguir:

Figura 42 - Modelo de criação de sentido em imagens proposto por Fraenza (2017). 


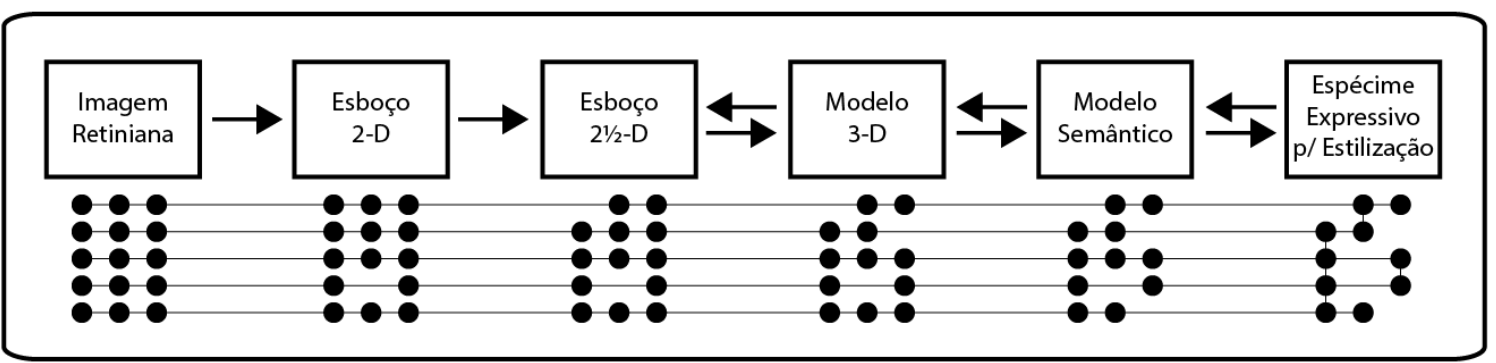

Fonte: imagem nossa, adaptada de Fraenza (2017)

Tal estrutura possui os seguintes elementos:

- Imagem Retiniana: é a imagem de algo presente no mundo das coisas, capturada pelo olho, podendo ser tanto um objeto ou ambiente, observados num ponto espacial e temporal específico, quanto uma imagem impressa, uma tela ou outro tipo de imagem produzida.

- Esboço 2-D: Segundo o autor, esta primeira etapa do processamento da imagem é o "da detecção de descontinuidades de intensidade na imagem retiniana, para estabelecer limites ou bordas visuais relevantes, em determinada posição e orientação x e y do campo visual" (FRAENZA, 2017, p. 22 - tradução nossa). Nesta etapa o observador reconhece as continuidades e descontinuidades da imagem retiniana.

- $\quad$ Esboço 21/2-D: A etapa seguinte é considerada por Fraenza a primeira etapa de nível consciente no processo. É no esboço 21/2-D que o indivíduo começa a reconhecer tais descontinuidades como volumes, e estabelecer relações como figura-fundo, ou como objetos independentes. Nesta etapa do processo, a identificação e o foco ainda estão depositados sobre o observador. A partir daqui tal foco se transfere para o objeto observado.

- Modelo 3-D: Enquanto na etapa do esboço 21/2-D fica explicitado "o que se vê", na etapa seguinte, a do modelo 3-D, explicita-se “o que é” o que se vê. Nesta instância, o indivíduo consegue prever certas formas do objeto visualizado, mesmo que tais formas estejam ocultas, bem como categorizar e nomear tais formas. Segundo o autor, "O poder de representar e de codificar classes é dado ao modelo 3-D por ele não ser inflexível como o estereótipo, já que a decomposição recursiva de um objeto pode 
especificar - já falando em termos computacionais - proporções e variações, ao invés de um valor único e fixo para tamanho, forma e disposição" (FRAENZA, 2017, p. 32 - tradução nossa). É nesta etapa que surge portanto uma consciência do que é o objeto, e de quais são os elementos que o compõe, dentro do repertório semiótico e linguístico do observador.

- Modelo Semântico: O modelo 3-D é uma concepção "independente" da referência visual, mas que acaba por ser relacionada com um espécime (o objeto observado). No modelo semântico, surge uma imagem de tipo (a categoria da qual este objeto faz parte). Segundo o autor, "É comum sustentar que as lembranças dos espécimes e dos tipos de espécimes se distinguem por sua vagueza ou sua generalidade, sendo as entidades individuais muito mais densas e específicas" (FRAENZA, 2017, p. 45 tradução nossa). Estes atributos de generalidade ou densidade se referem, segundo o autor, ao semas ${ }^{123}$ que categorizam o tipo de objeto. O modelo 3-D possui uma densidade maior de semas por se referir a um espécime, enquanto o modelo semântico, por ser um tipo, possui uma densidade sêmica menor.

- Espécime expressivo por Estilização: A partir de uma terminologia de Umberto Eco (2014), Fraenza propõe que é nesta etapa que começam a surgir correlações do tipo ratio facilis $^{124}$ de um conjunto de semas e uma forma expressiva padrão, por convenção social e por experiências anteriores, permitindo por exemplo que se reconheçam diferentes exemplares de um mesmo "tipo", sem que necessariamente tenha-se entrado em contato com ele antes. Caso esteja-se diante da ocorrência mais incomum de uma figura mais estilizada, menos próxima das referências já conhecidas, operam-se correlações de ratio Difficilis ${ }^{125}$, onde, na ausência de um tipo expressivo

\footnotetext{
${ }^{123}$ Sema é uma unidade mínima da significação, específica do domínio da semântica. Descrito em detalhes no glossário no fim da dissertação.

${ }^{124}$ Ratio Facilis é uma ocorrência expressiva que concorda com um tipo expressivo institucionalizado, como por exemplo um sinal de trânsito. Descrito em detalhes no glossário no fim da dissertação.

${ }^{125}$ Ratio Difficilis é uma ocorrência expressiva que concorda com um conteúdo, pois não há um tipo expressivo institucionalizado, como por exemplo um desenho estilizado da figura humana. Descrito em detalhes no glossário no fim da dissertação.
} 
institucionalizado, se busca a criação do código necessário para a interpretação ${ }^{126}$. Em ambos os casos, é este espécime expressivo por estilização que é acessado quando se desenham elementos "por memória" ou "por semelhança".

A respeito deste sistema de processamento semiótico das imagens, é necessário apontar que, ainda que a fase inicial de apreensão se refira a elementos visuais, a partir da etapa do modelo semântico, há uma maior abstração e, por consequência, a codificação destas imagens junto a um conjunto independente de unidades expressivas tipo linguístico. Certos modelos semânticos, como a ação do ato de sentar-se ou apontar, acabam por condensar, além do Modelo Semântico/Espécime Expressivo, semas linguísticos ou ainda unidades de significado de outras naturezas.

Fraenza postula que o Modelo Semântico permite à estrutura conceitual "ser despojada de um grande número de características descritivas ad hoc, codificando essas informações no formato do modelo 3d, onde não é ad hoc, mais precisamente para que esse nível de representação é projetado.” (FRAENZA, 2017, p. 47 - tradução nossa). Este Modelo 3-D/Modelo Semântico opera de modo similar ao processo de análise sêmica idealizado por Bernard Pottier (1978), encapsulando várias combinações sêmicas no Modelo 3-D/Modelo Semântico.

Por último, é necessário apontar que as setas bidirecionais presentes entre o Esboço 21/2-D e o Espécime expressivo representam o fato de que este processo de construção é de duas vias, já que, assim como o que é visto e identificado no Esboço 2D é codificado até um Modelo Semântico/Espécime Expressivo, modificações no código institucionalizado e outras experiências visuais acabam por modificar o modo como o próprio Esboço 21ํ2-D é codificado.

Dada a grande variação de estilos e tipos de ilustração que circulam nos fóruns presentes nesta pesquisa, serão analisadas duas categorias de ilustração que não devem ser consideradas como exemplares de uma categoria específica, mas sim como dois extremos de um continuo

\footnotetext{
126 É importante apontar, como descrito no glossário, que esta “invenção" proposta numa ocorrência ratio difficilis é, na verdade, uma invenção de código, devido à necessidade. Um processo de invenção onde se reorganizam diversos conteúdos dentro de um mesmo sistema de expressão (como uma skin de jogos, pensando no objeto desta pesquisa) faz parte do ratio facilis; Segundo Eco, a ocorrência da ratio difficilis vem da necessidade do produtor de "ter uma ideia bastante clara daquilo que quer dizer mas não sabe como dizê-lo" (ECO, 2017, p. 167).
} 
estabelecido entre uma reprodução mais fidedigna às regras da representatividade realista, e uma representação mais estilizada e experimental.

A imagem a seguir é referente à personagem D.Va (pronunciado "Diva", para simular a linguagem de jogadores profissionais de videogame) de Overwatch, retirada de uma das telas presentes dentro do próprio jogo:

Figura 43 - Captura de tela de jogo, mostrando a personagem D.Va, de Overwatch.

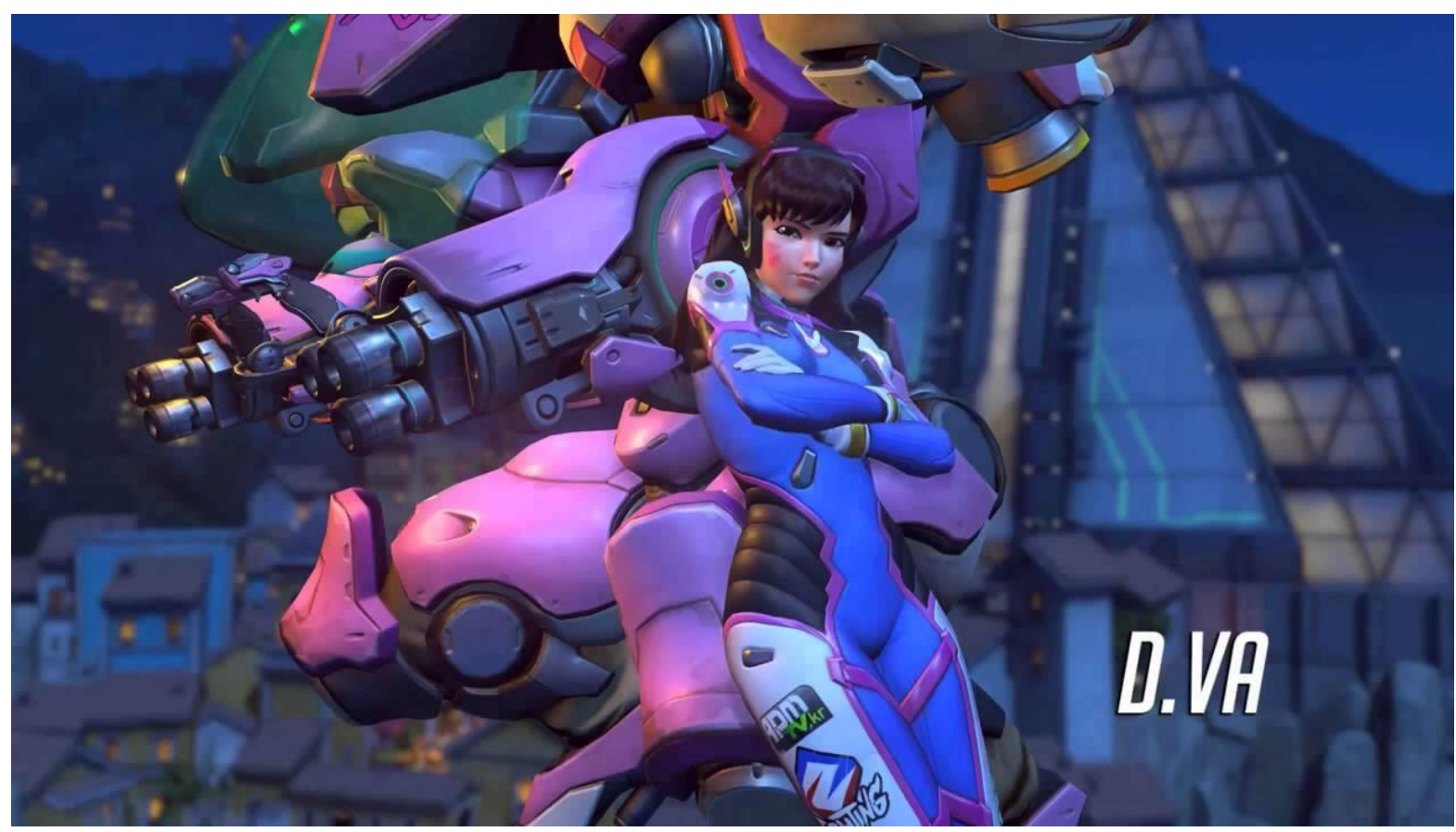

Fonte: Blizzard (2020).

No videogame, o jogador controla um avatar tridimensional, que é a origem da terminologia utilizada por Fraenza: após relativamente pouco tempo de jogo com as personagens de $L O L$ e Overwatch no ambiente digital, os jogadores já possuem sólidos modelos 3D em suas cabeças. Porém, a constante interação e produção dos fãs de material textual e gráfico sobre tais universos digitais (e que será discutido novamente no capítulo seguinte) acaba por engrossar a concentração de semas que orbitam os Modelos semânticos/ Espécimes expressivos das personagens. Olhemos os exemplos a seguir, ambos relativos à personagem D.Va (Overwatch) e retirados do site Danbooru: 


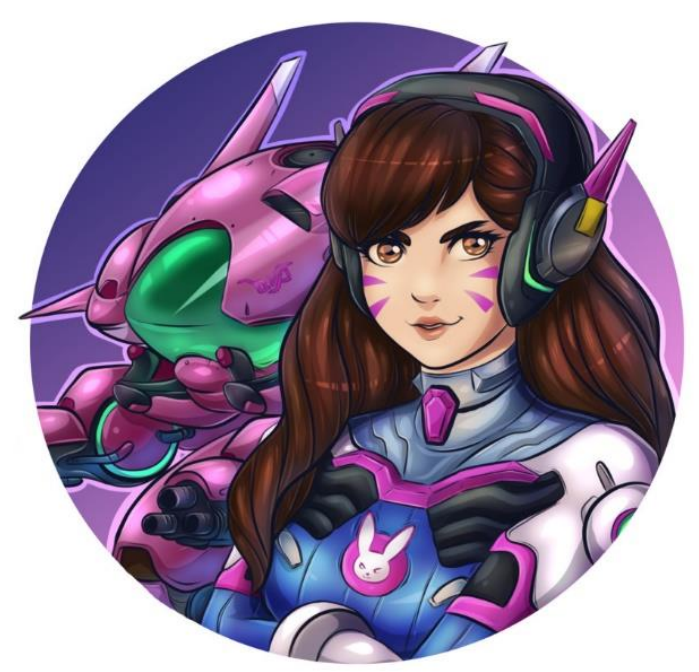

Fonte: Danbooru $(2020)^{127}$.

Na imagem acima, há uma correlação do tipo ratio facilis, onde o estilo da composição e do traço do autor busca mimetizar tanto o Modelo 3D da personagem (bem como seu Modelo Semântico) quanto reproduzir a perspectiva captada pelo olho humano na observação do mundo. Neste tipo de ilustração, convidam-se expressões que reafirmem os padrões e convenções sociais, tanto ocorridos dentro do jogo e conhecidos por sua comunidade, quanto os padrões do mundo das coisas. Pode-se ver também que este tipo de ilustração faz um uso do universo do jogo como metatexto, pois não o copia, mas reafirma os elementos canônicos do texto-jogo. Este tipo de ilustração pode, inclusive, se fazer presente em peças de caráter mais fantasioso:

Figura 45 - Ilustração da personagem D.Va, de Overwatch.

${ }^{127}$ Disponível em: <https://danbooru.donmai.us/posts/2176428>. Acesso em: 10 mar. 2021. 


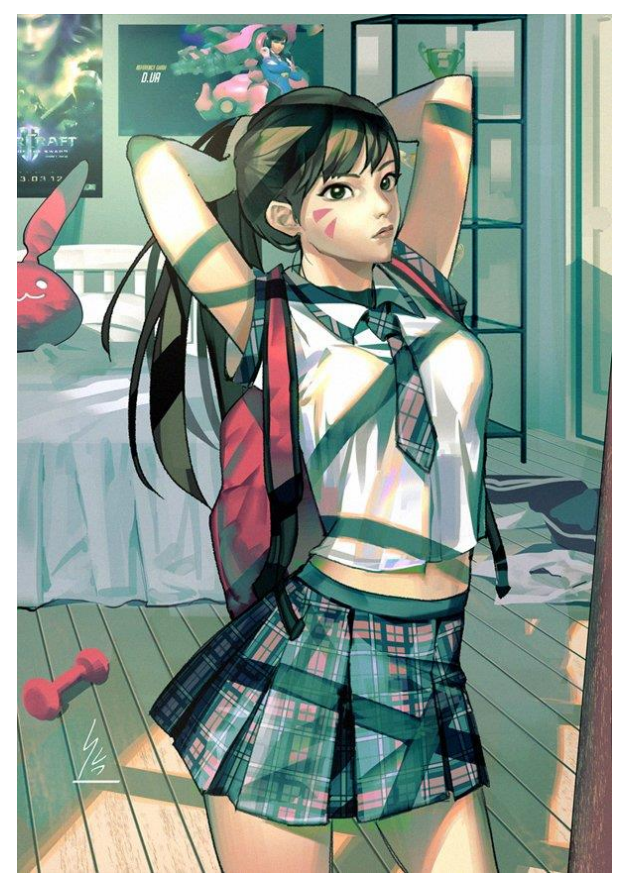

Fonte: Danbooru $(2020)^{128}$.

$\mathrm{Na}$ imagem acima, o artista ilustra a personagem D.Va como uma colegial; ainda que esta configuração não exista no universo do jogo, a representação se mantém uma ratio facilis pois o estilo continua buscando uma mimetização do mundo das coisas, seguindo os padrões e convenções sociais de representação destes elementos e fazendo uma leitura metatextual dos elementos do universo ficcional do jogo e dos universos culturais do mundo das coisas.

Figura 46 - Ilustração da personagem D.Va, de Overwatch.

${ }^{128}$ Disponível em: <https://danbooru.donmai.us/posts/2389378>. Acesso em: 10 mar. 2021. 


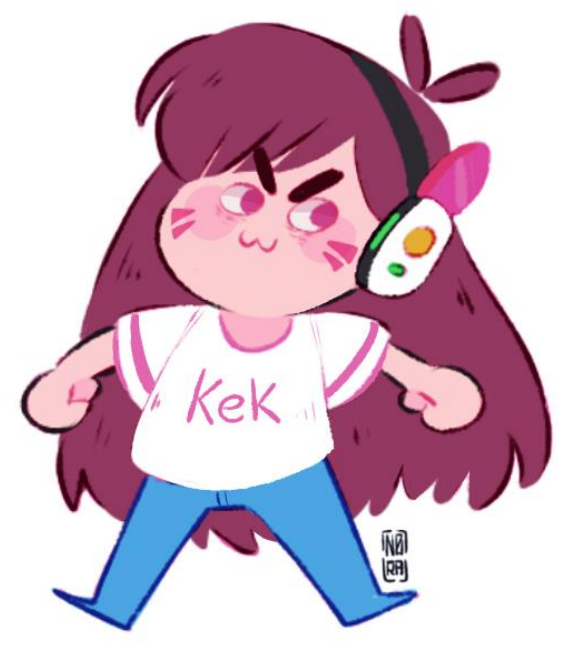

Fonte: Danbooru (2020) $)^{129}$.

No segundo extremo dos tipos de ilustração encontrados no corpus de análise, temos uma ilustração da personagem D.Va que opera em ratio difficilis; onde há uma maior concentração sêmica disponível incialmente no Espécime Expressivo, e onde se faz necessário o desenvolvimento de novas codificações ${ }^{130}$, baseadas no conhecimento do observador, para a compreensão da imagem. A intersecção intertextual de Genette aqui se manifesta como um uso intenso de hipertextos, pois além do caráter de pastiche, há apenas referências indiretas aos universos do jogo e do mundo das coisas (o que é reforçado pela menor densidade sêmica promovida durante uma ratio difficilis).

É importante ressaltar, novamente, que estes dois "estilos" apresentados não são modelos estanques, mas sim exemplos que ajudam a explicar a variação entre as caracterizações de ilustrações em ratio facilis e ratio difficilis.

${ }^{129}$ Disponível em: <https://danbooru.donmai.us/posts/2385786>. Acesso em: 10 mar. 2021.

${ }^{130}$ No caso, existem certas codificações que regem tal imagem: o estilo gráfico da imagem é inspirado no cartunista japonês Bkub Okawa, famoso por desenhar pequenas meninas hostis e endiabradas, que a comunidade digital chama de "gremlins". A inscrição "kek" na camiseta também é um sub-nicho da cultura gamer asiática (sendo usado como riso, similar ao "rsrs" usado pelos brasileiros), mas que nos últimos anos passou a ser utilizado pela alt-right (o movimento da juventude ultradireitista, muito presente em fóruns de games e filmes), sendo associado a outros símbolos como Pepe the Frog. Ainda estes sistemas possuam suas estruturas, eles não são padrões e convenções sociais dentro da comunidade de jogadores e fãs de Overwatch, o que justifica sua denominação como mais próxima de uma Ratio Difficilis nesta pesquisa. 
Dentro do sistema proposto por Marino (2018) sobre o continuum memético, as imagens do tipo ratio facilis serão consideradas nesta pesquisas como tendentes a ocuparem a função de Remakes. Isto ocorre devido a sua reprodução de convenções sociais na formas de modelos semânticos ser um procedimento similar às "práticas meméticas, como reencenar a ação exibida numa fotografia ou vídeo que serve como texto original" (MARINO, 2018, p. 27). Já as imagens de ratio difficilis, possuem a tendência de se configurarem como Samples e, em menor frequência, Remixes; não há aqui uma tentativa de reinterpretar (tanto a nível visual quanto a nível de conteúdo), mas sim a inserção da personagem em outros sistemas de convenções sociais, o que colabora na geração do punctum descrito por Barthes. Nas palavras de Marino, isto representa "personagens altamente reconhecíveis que são colados ou inseridos em figuras preexistentes” (MARINO, 2018, p. 26).

É importante reforçar que tal interpretação não se propõe a ser uma tipologia de ilustrações dentro do continuum memético, mas sim a proposição de que as ilustrações que surgem nos fóruns presentes neste corpus podem apresentar traços de Sample, Remix e/ou Remake, e isto dependerá do quão reconhecíveis e convencionadas são as técnicas e os semas aplicados em tal ilustração. Dependendo do momento e do contexto, uma mesma imagem pode, inclusive, mudar de posição no continuum memético, pois as convenções dentro dos ambientes digitais possuem maior fluidez e velocidade em seu desenvolvimento.

\subsubsection{Vídeo-análises}

O pesquisador brasileiro Marcos Kalil Filho, em sua tese de doutorado (2020), analisa semioticamente os modos de vida dos daily vloggers, que são parte do elenco de celebridades de plataformas como o Youtube. Os daily vloggers possuem similaridade com os perfis especialistas em análise de jogos - o que transforma tais observações em objeto de interesse desta pesquisa. Segundo o autor, a fama promotora de tal indivíduo não pode ser separada deste, pois "A notoriedade de parcela significativa dessas celebridades, inclusive, conforma uma tautologia, ou seja, não é por que cumprem uma função social ou realizaram um feito heroico que são celebrados, mas em decorrência da própria notoriedade.” (KALIL FILHO, 2020, p. 141). 
Os efeitos de construção dos vídeos do Youtube são coagidos pela estrutura da plataforma, e costumam construir o efeito de sentido de pessoalidade e subjetividade, através de câmera próxima, discurso próximo da fala, discurso em primeira pessoa, entre outros.

Kalil Filho chama a atenção para a terminologia presente no Youtube, que permite antever quais as práticas relacionadas a publicações de vídeo, estas práticas sendo aplicáveis também aos canais de jogos, objeto da presente pesquisa. O próprio uso do termo canal, de origem rádio televisiva, para definir o os perfis da plataforma, já induz à prática de organização de um tipo de conteúdo dentro de tal perfil, bem como a de espectadores interessados em tal conteúdo.

Outro elemento importante de ser apontado, pois ajuda a definir como operam as vídeoanálises sobre jogos dentro do continuum memético, é a prática neoliberal que subjaz na atividade do videomaker de Youtube. A atividade do videomaker é um modelo de negócios no qual o enunciador-produtor arca com todos os riscos envolvidos. O sucesso do canal depende, para além do conteúdo vinculado, das escolhas sêmicas de seu discurso, pois são tais escolhas que o posicionam dentro do algoritmo de buscas e sugestões dentro do Youtube, e que Kalil Filho considera ser o verdadeiro motor de desenvolvimento da plataforma.

O enunciatário será, acima de tudo, um cliente sobre o qual as estratégias de fidelização deverão ser desenvolvidas para, de um lado, melhor servi-lo e, de outro atraí-lo tanto o quanto for possível. Como a meta é manter o consumidor na plataforma o máximo de tempo para que sua audiência gere receita de publicidade e mais dados de uso para refinar o próprio algoritmo, o efetivo conteúdo dos textos-enunciados importará pouco. (KALIL FILHO, 2020, p. 153)

Tal postura neoliberal descrita acima, possui dois efeitos em nosso continuum memético analisado. O primeiro é a tendência, do enunciador da vídeo-análise, em buscar os punctuns meméticos presentes em cada movimentação do universo de $L O L$ e Overwatch, pois o poder de replicação do elemento memético permite ao enunciador promover seus vídeos e seu projeto de enunciação neoliberal. Outro efeito é a predileção do enunciador da vídeo-análise pelas práticas do remake: para que o conteúdo atraia visualizações, ele deve tratar de temas que já tenham um grau considerável de cristalização, portanto que já tenham ao menos remixes circulando pela comunidade. 
A predileção pelo remake permite que o enunciador das vídeo-análises imprima sua própria marca (vocal, gráfica, narrativa) ao remake construído, como uma espécie de "branding de si”, impresso em seus remake, que almejam ser propagados pelo fórum. Abaixo, mostramos os arquivos de vídeos do canal Stylosa, um youtuber britânico que analisa jogos competitivos de tiro em primeira pessoa, em especial Overwatch:

Figura 47 - Canal de video-análises de Stylosa.

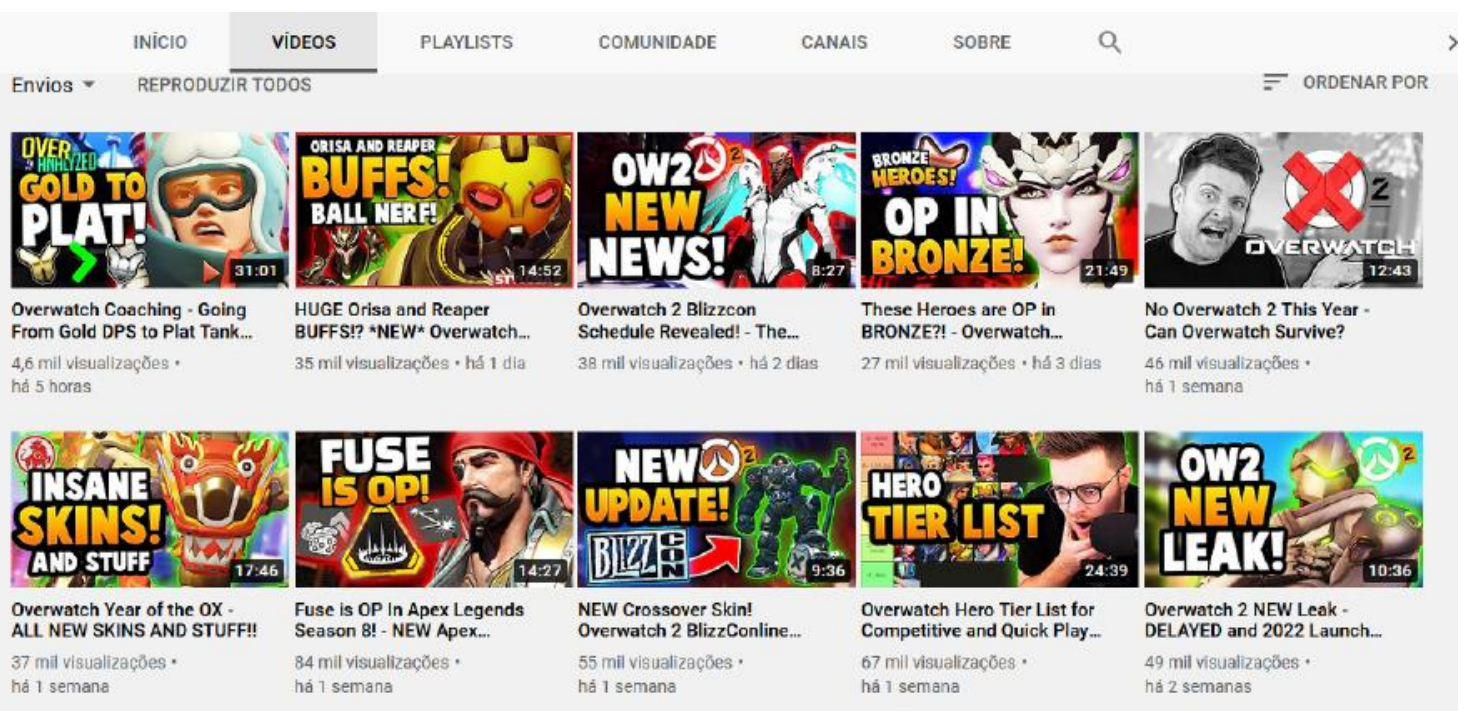

Fonte: Youtube $(2021)^{131}$.

Nesta imagem é possível perceber diversos elementos que apontam para o "branding de si": O aparecimento do próprio Stylosa nas imagens de propaganda do video, em meio a personagens do jogo, a padronização de fontes e layout. É também visível que os vídeos abordam discursos com punctuns meméticos que perpassam a comunidade: vazamentos sobre atualizações futuras dos jogos, efeitos de patches, bem como estratégias de como se tornar um jogador de elite.

Como observou Kalil Filho anteriormente, e a presente pesquisa pode confirmar tal postulação nas vídeo-analises do corpus de estudo, o conteúdo divide sua relevância com o estilo

${ }^{131}$ Disponível em: <https://www.youtube.com/c/stylosa/videos>. Acesso em: 10 mar. 2021. 
do analista, que propaga na verdade o seu remake pessoal dos punctuns meméticos dos universos de $L O L$ e Overwatch.

\subsubsection{Quadrinhos/Tiras}

Muito frequentemente, as postagens multimídias feitas por usuários apresentam tiras que podem ir de poucos quadros, como as vistas nos jornais, até edições digitais de quadrinhos com várias páginas de extensão, às vezes possuindo mais de um volume. Estas postagem se utilizam de muitas das convenções tradicionais da linguagem dos quadrinhos, sendo porém feitas no ambiente de fórum, dentro das threads de comentários, ou mesmo como uma postagem, que possui uma lista de comentários própria.

Daniele Barbieri, semiólogo italiano autor do livro A Linguagem dos Quadrinhos (2017), propõe um estudo comparativo da linguagem dos quadrinhos, onde esta é observada em relação com outras linguagens, sendo que esta comparação considera relações como a Inclusão (a inclusão dos quadrinhos dentro da linguagem geral da narrativa), Geração (o quadrinho como uma derivação da ilustração, caricatura e literatura ilustrada), Convergência (a aproximação de elementos dos quadrinhos com elementos da fotografia, teatro, cinema e imprensa) e a Adequação (a adequação da linguagem cinematográfica à linguagem dos quadrinhos).

Tal estudo é interessante para esta pesquisa pois, enquanto existem excelentes trabalhos que estudam os elementos e relações particulares à linguagem dos quadrinhos (como os trabalhos fundamentais de Will Eisner e Scott McCloud), uma oportunidade ao se optar pela análise comparativa, nas palavras do próprio autor, é que "Explorar esta linguagem por meio de sua comparação com outras é um modo de introduzir a discussão da comunicação por meio dos quadrinhos na discussão geral da comunicação" (BARBIERI, 2017, p. 21). Com esta abordagem espera-se localizar melhor o modo como o quadrinho cria ou propaga os elementos meméticos dentro do continuum.

Alguns dos elementos característicos da linguagem dos quadrinhos, em comparação com outras, são a proeminência da natureza narrativa em detrimento da natureza pictórica de uma 
ilustração, por exemplo. Segundo o autor, enquanto este comenta uma ação, aquela conta. "Nos quadrinhos, pelo contrário, cada vinheta tem uma função diretamente narrativa; inclusive com ausência de diálogos e legendas ou texto narrativo, a vinheta conta um momento da ação que constitui parte integrante da história, e prescindir dela supõe prejudicar a boa medida da compreensão" (BARBIERI, 2017, p. 27).

A respeito da ilusão de profundidade e construção do espaço pictórico, Barbieri faz observações que são alinhadas à análise da percepção visual de Fernando Fraenza, que foi utilizada anteriormente nesta pesquisa, a respeito das ilustrações. É possível observar a oposição entre a mimetização do mundo das coisas, tendente à Ratio Facilis, e a estilização, tendente à Ratio Difficilis. Para além das justificativas, já anteriormente descritas no modelo de Fraenza, Barbieri ressalta que a estilização e a simplificação possuem uma dimensão narrativa, própria dos quadrinhos: "Trata-se da mesma exigência de simplicidade que levará à eliminação da profundidade em muitas tiras cômicas, anos depois, mas que joga aqui com o fato de que o leitor, enquanto tinha visto aquela profundidade, conhece-a e já não há necessidade de repeti-la" (BARBIERI, 2017, p.106).

Em linhas gerais, é possível considerar que, do ponto de vista do continuum memético de Marino, os quadrinhos possuam uma abrangência similar ao que foi observado no item relativo à Ilustração, discutido mais acima. Porém, a leitura não pode ser considerada parecida. Tomemos os exemplos a seguir:

Figura 48 - Quadrinhos feitos por fãs de LOL. 


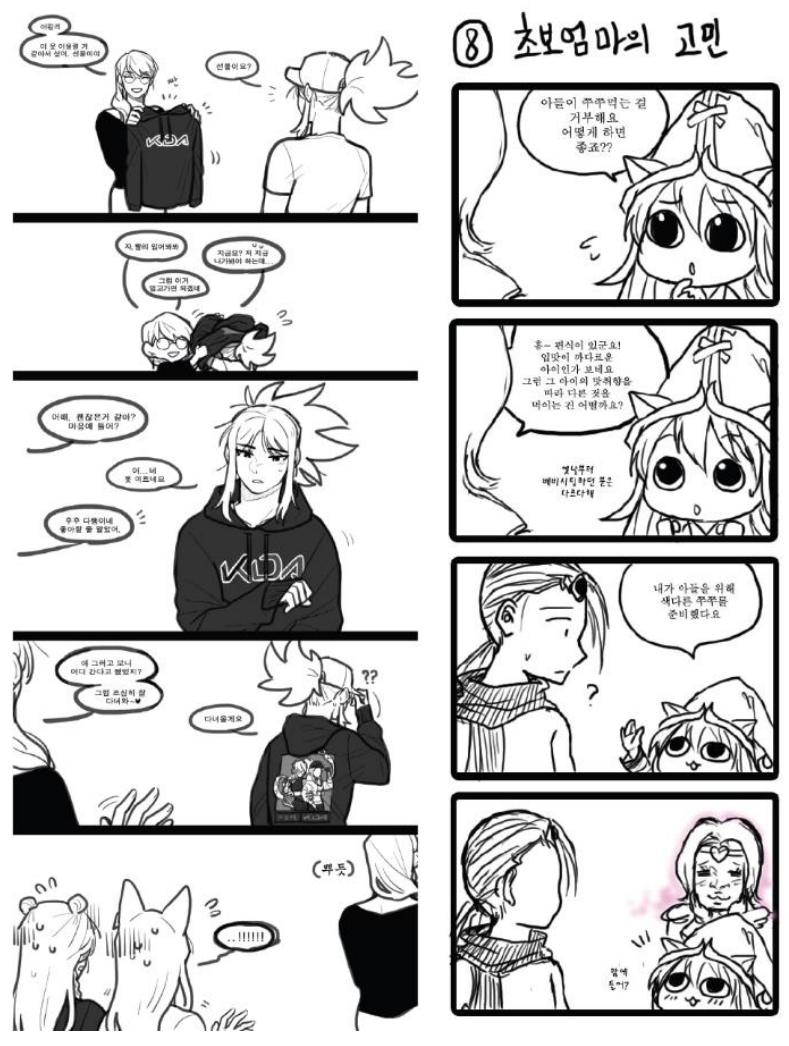

Fonte: Danbooru $(2020)^{132}$.

Nos dois quadrinhos apresentados na imagem acima, ainda que existam diferenças entre uma abordagem pictórica do quadrinho à esquerda (mais próximo de uma representação do "mundo das coisas") em relação ao quadrinho da direita (mais estilizado), ambos possuem todos os códigos sociais que caracterizam o estilo de quadrinhos oriental ${ }^{133}$.

Segundo Barbieri, os "tipos" de quadrinhos existentes, como cartuns, quadrinhos de superheróis ou romance, podem ser identificados pelas convenções sociais e estéticas que regem o que

132 Disponível em: <https://danbooru.donmai.us/posts/4043511 e https://danbooru.donmai.us/posts/1519904>. Acesso em: 10 mar. 2021.

133 É importante frisar que existem diferenças entre os gêneros de quadrinhos asiáticos, como o Manga japonês (preto e branco, leitura da direita à esquerda, estilização do traçado e excesso de informação nos quadros) e o Manhwa coreano (colorido, leitura da esquerda à direita, desenhos mais anatômicos e quadros com menos acúmulo de informações). Quando, como no caso dos exemplos dados, os quadrinhos são produções feitas na e para circular na internet e nos fóruns, não é incomum que os gêneros se misturem. Nos dois quadrinhos apresentados, optamos por defini-los genericamente como "quadrinho oriental" pois, ainda que sejam híbridos entre mangas e manhwas, estes códigos e convenções estilísticas possuem uma visível diferença dos quadrinhos “ocidentais” (Europa e América). 
está representado no quadrinho. A respeito da tradução de uma mesma obra de uma mídia (animação) para outra (quadrinhos), e do processo de adequação das convenções sociais e estéticas reconhecidas na animação para a linguagem dos quadrinhos, o autor afirma que:

Não é que a representação do movimento e dos signos de movimento nasça com o desenho animado: encontramo-los já em Yellow Kid, em 1896. Entretanto, a estreita relação com o cinema de animação devida à presença dos mesmos personagens fez necessário até certo ponto o desenvolvimento de novos signos de movimento muito mais inventivos do que já havia sido até então. (BARBIERI, 2017, p. 198)

A imagem a seguir apresenta mais alguns exemplos de quadrinhos retirados do fórum de imagens Danbooru:

Figura 49 - Quadrinhos feitos por fãs de Overwatch e LOL.

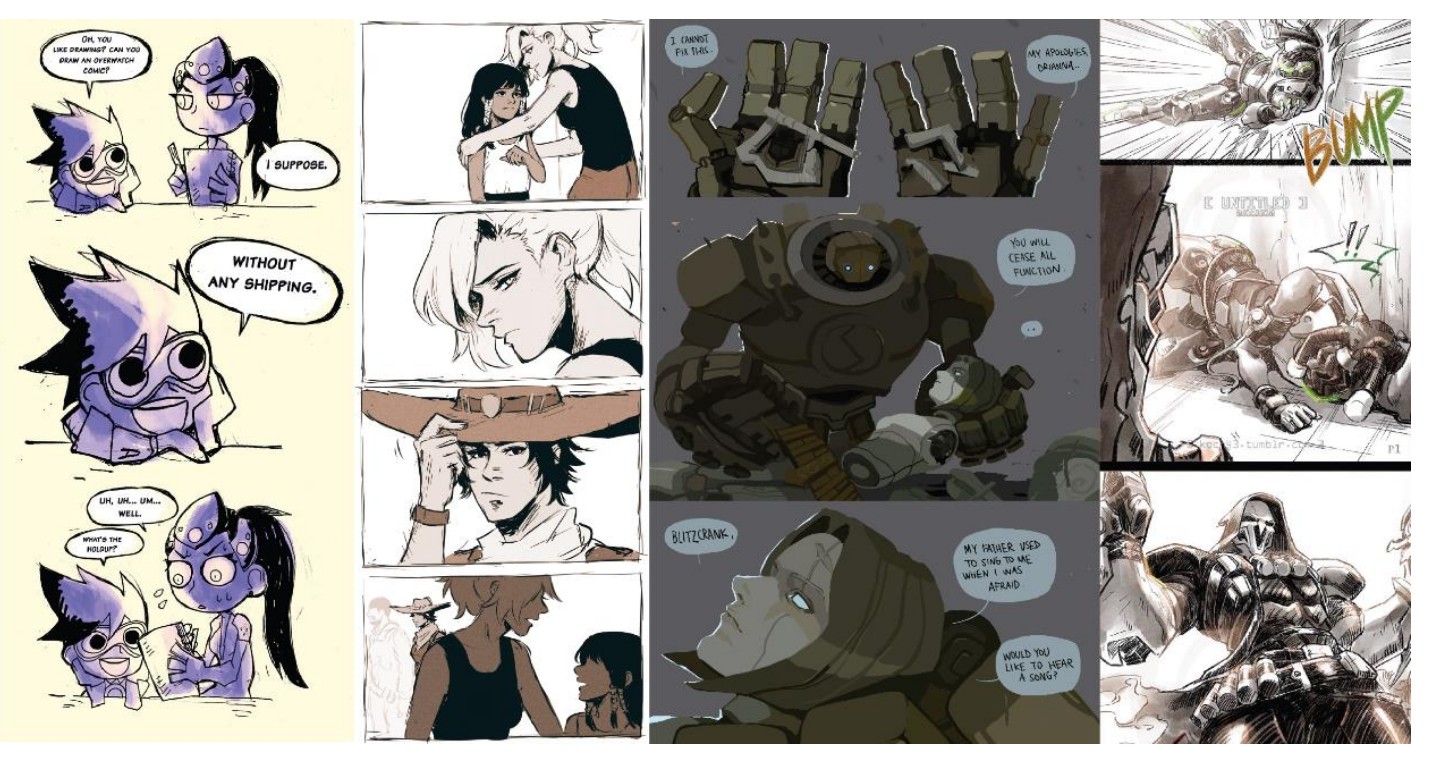

Fonte: Danbooru $(2020)^{134}$.

Na sequência de quadrinhos apresentada acima, há uma pletora de semas e elementos estilísticos presentes em cada uma das sequências, que contribuem para construir o "estilo" de cada traçado: O quadrinho mais à esquerda possui um estilo mais caricaturesco, reforçado pelo traço

134 Disponível em: <https://danbooru.donmai.us/posts/2456113>, <https://danbooru.donmai.us/posts/2466306>, <https://danbooru.donmai.us/posts/1885649>, <https://danbooru.donmai.us/posts/2530926>. Acesso em: 10 mar. 2021. 
irregular; o quadrinho mais à direita expressa tridimensionalidade, volumes e texturas de maneira mais anatômica. Porém, os quatro exemplares apresentados são legíveis como quadrinhos: as constrições de fluxo de leitura, separação em quadros para a estruturação narrativa e outros elementos apontados por Barbieri (2017) são raramente subvertidos nos quadrinhos observados dentro do corpus pesquisado.

Ainda que os quadrinhos possam ser observados, nos mesmos moldes do que foi proposto na análise da ilustração, uma gradação entre ocorrências de ratio facilis (Remakes) e ratio difficilis (Samples e Remixes), este segundo tipo acaba por ser mais incomum dentre os quadrinhos, pois os códigos e constrições de leitura específicos deste meio são muito mais homogêneos do que os códigos e constrições da ilustração. Um tipo característico de Remix que utiliza a linguagem de quadrinhos é um quadrinho cujo punctum seja uma imagem memética, como o exemplo abaixo:

Figura 50 - Quadrinho de estilo Remix.

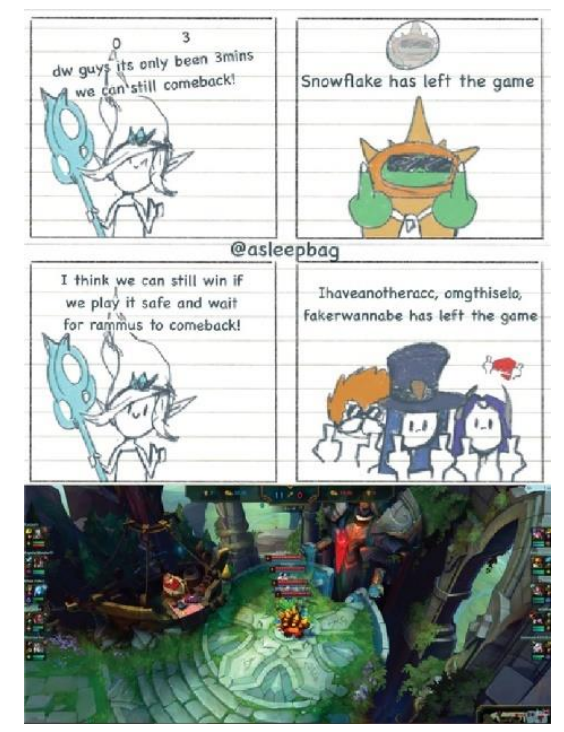

Fonte: Reddit $(2020)^{135}$.

O quadrinho acima possui uma construção de história em quadrinhos, mas parte fundamental do punctum, que o torna memético, é o uso da tela de jogo, no último quadrinho de

135 Disponível em: <https://www.reddit.com/r/leagueoflegends/comments/gt9ej1/comic_idk_why_im_not_climbing _this_season/>. Acesso em: 10 mai. 2021. 
uma imagem do jogo, que representa uma derrota acachapante do sujeito, após todos os seus aliados o abandonarem no meio de uma partida. Os quadrinhos que apresentam estas estratégias de remix existem, porém são minoria em relação à circulação dos quadrinhos sem tais referências.

\subsubsection{Machinimas ${ }^{136}$ e GMods ${ }^{137}$}

Machinimas são vídeos de animação 3D que possuem a particularidade de que todas as cenas, posições de câmera e efeitos visuais são feitos a partir da própria interface dos jogos nos quais eles se passam. Segundo Henry Lowood, autor do artigo "A tecnologia encontrada: Jogadores como inovadores na produção de machinima" os Machinimas são a "produção de filmes animados com o software utilizado para desenvolver e interagir com games de computador" (LOWOOD, 2011, p. 11).

Originalmente, a prática de Machinimas surgiu nos anos 90, inicialmente entre as comunidades de jogadores de Doom (1993) e Quake (1996). Dentre as funcionalidades destes jogos, havia a possibilidade de se gravar seu jogo (gameplay), com o objetivo de que o jogador usasse as gravações como modo de aprimorar a qualidade do seu jogo. Com o tempo, os vídeos em $1^{\text {a }}$ pessoa do jogo começaram a ser divulgados pelos seus autores, bem como houve o início do estabelecimento de narrativas. Logo criou-se uma cultura de narrativização de tais vídeos, e as próprias desenvolvedoras começaram a incentivar a produção de tais conteúdos, fazendo concursos e oferecendo ferramentas específicas na interface do jogo, voltadas para a produção e captura dos vídeos, como câmeras em $3^{\text {a }}$ pessoa e instant replays. O machinima pode ser considerado uma criação coletiva, resultante da relação desenvolvedor/jogador, pois "Foram os desenvolvedores que criaram essa tecnologia, mas não previram esta aplicação, que foi descoberta, testada e melhorada por estes jogadores (LOWOOD, 2011, p. 29).

\footnotetext{
136 Termo criado a partir das palavras machine (máquina) e cinema (cinema). Define animações construídas dentro da interface dos próprios jogos de computador. Descrito em detalhes no glossário no fim da dissertação.

${ }^{137}$ Nome popular atribuído ao jogo Garry's Mod, uma “caixa de areia de conceitos físicos”, que permite a criação de diversos jogos, utilizando inclusive conteúdos pertencentes a outros jogos como LOL e Overwatch. Descrito em detalhes no glossário no fim da dissertação.
} 
O refinamento das práticas como o machinima é inevitável, segundo Lowood, por ser uma das duas práticas com as quais o jogador pode se apresentar como o actante competente e capaz dentro da comunidade dos jogos: A primeira é a do "Deus do Joystick", onde suas habilidades em cumprir o programa narrativo do jogo são vistas como exemplares (e, em certa medida, um referencial de como o jogo deve ser jogado). A segunda é a do "jogador-programador", um usuário que conhece a mecânica e a programação do jogo tão profundamente, que é capaz de criar $\operatorname{mods} s^{138}$, encontrar bugs ou glitches $^{139}$ e produzir machinimas. $\mathrm{O}$ autor nota como a natureza destes grupos é competitiva e exibicionista.

Figura 51 - Machinima de Overwatch.

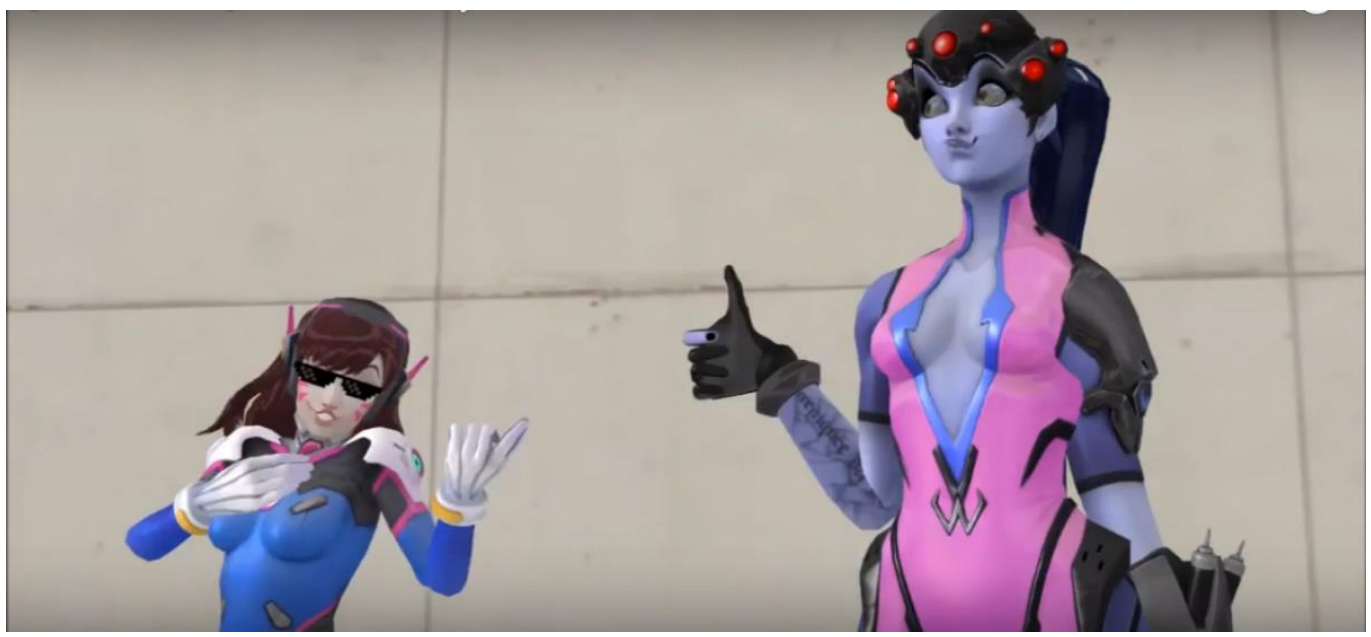

Fonte: Youtube $(2020)^{140}$.

A criação de machinimas e o uso de mods são considerados uma das atuais estratégias de sobrevivência da franquia e se tornou possível graças ao estabelecimento da produção de jogos como uma indústria. "A padronização da produção de games também abriu os portões para uma enxurrada de conteúdos criados por jogadores, o que, por sua vez, estenderia a vida comercial do

${ }^{138}$ Mods são alterações estéticas e, às vezes, funcionais, promovidas por fãs dentro da programação de um jogo. Descrito em detalhes no glossário no fim da dissertação.

${ }^{139}$ Bugs são comportamentos inesperados dentro da programação de um jogo que fazem este parar de funcionar. Glitches são erros que, por serem menos graves, não fazem o jogo parar de funcionar, mas alteram seus atributos de forma inesperada. Descritos em detalhes no glossário no fim da dissertação.

${ }^{140}$ Disponível em: <https://www.youtube.com/watch?v=XDm6RYSRpBg>. Acesso em: 10 mar. 2021. 
game" (LOWOOD, 2011, p. 18). Henry Jenkins, já no meio dos anos 2000, falava a respeito desta "fidelidade participativa" da comunidade de fãs, e como ela era capitalizada pelas marcas, utilizando conceitos como Lovemarks e "Capital Emocional". Segundo o pesquisador:

Os consumidores não apenas assistem aos meios de comunicação; eles também compartilham entre si ao que assistem - seja usando uma camiseta proclamando sua paixão por determinado produto, postando mensagens em uma lista de discussão, recomendando um produto a um amigo ou criando uma paródia de um comercial que circula na internet. A expressão pode ser vista como um investimento na marca, e não simplesmente uma exposição a ela (JENKINS, 2009, p. 103)

Neste sentido, os machinimas são uma estratégia de fidelização da comunidade de jogadores, que possui exemplos de sucesso como no caso do jogo Team Fortress 2, e que também se encontra em $L O L$ e Overwatch. O ápice desta estratégia pode ser encontrado no lançamento, em 2004, do jogo Garry's Mod (doravante denominado GMod).

Figura 52 - Machinima de LOL.

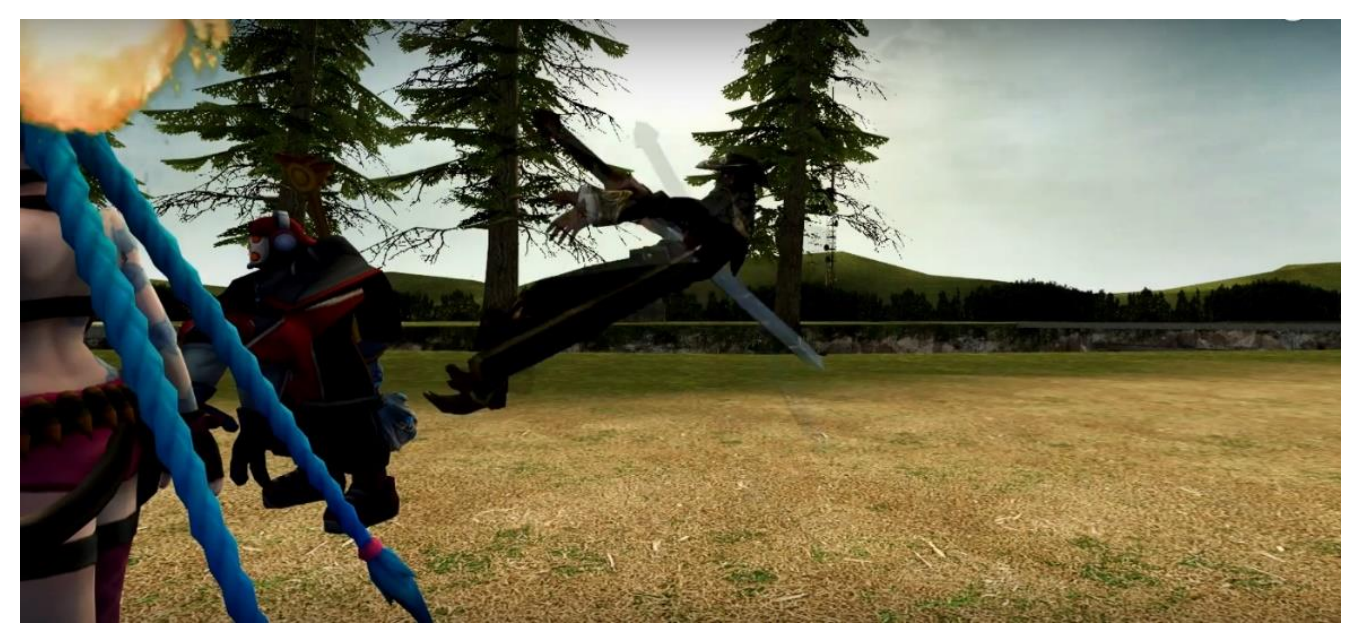

Fonte: Youtube (2020) ${ }^{141}$.

O GMod foi lançado em 2004, pela desenvolvedora Facepunch Studio, e publicado na plataforma de jogos online Valve, que já vendeu mais de 10 milhões de cópias em todo o mundo ${ }^{142}$.

\footnotetext{
${ }^{141}$ Disponível em: <https://www.youtube.com/watch?v=bTe_gOfwHuM>. Acesso em: 10 mar. 2021.

${ }^{142}$ GARRY MOD. Gmod, Valve. Disponível em: <https://store.steampowered.com/app/4000/Garrys_Mod/>. Acesso em: 18 ago. 2020.
} 
Um dos elementos diferenciais deste jogo é que funciona como um Sandbox ${ }^{143}$, onde há funcionalidades como editor de expressões faciais, corpos e texturas, bem como a gravação de sequências e gatilhos de acontecimentos físicos dentro do jogo. Tais funcionalidades são ideais para o desenvolvimento de Machinimas.

Para além de possuir uma mecânica propícia para a criação de Machinimas e outros conteúdos do fandom, o GMod possui diversas bibliotecas, organizadas pela própria Valve e preenchidas pelos fãs e jogadores, com modelos de personagens e elementos de jogos como Overwatch, LOL, Team Fortress 2 entre outros, devidamente programados para o uso dentro do GMod. Esta dinâmica representa um caso do uso do capital emocional descrito por Jenkins: fãs e jogadores contribuindo ativamente para propagar e promover gratuitamente o conteúdo de uma empresa (que no caso, são as desenvolvedoras dos jogos).

Do ponto de vista da teoria de intertextualidade de Genette, esta pesquisa considera que os machinimas utilizam o texto-jogo como um intertexto; os próprios elementos gráficos e algumas programações computacionais do jogo estão presentes nos machinimas, o que pode se configurar como uma citação direta ao texto-jogo.

Do ponto de vista do continuum memético de Marino, pode-se pensar que os machinimas atuam como o remake de Spaziante. Na produção dos machinimas, há uma reapropriação e reutilização de modelos, padrões estéticos e outras convenções, que são herdados dos próprios jogos, das mecânicas do GMod (ou outro programa usado para a criação de Machinimas) e de convenções que já existem dentro da comunidade de jogadores. Na maioria dos casos, os machinimas podem ser vistos como reinterpretações mais elaboradas e realistas (considerando que o "realismo" neste caso se refere à maior semelhança dos machinimas com o ambiente visto/ouvido pelo jogador durante os jogos) de conceitos e elementos meméticos que já se encontram em circulação na comunidade de fãs e jogadores, mas em formas mais simples, como imagens ou textos.

143 Sandbox é um gênero de jogo que funciona como um cenário aberto, cheio de elementos oferecidos ao jogador para que este se divirta interagindo com eles pelo espaço. Descrito em detalhes no glossário no fim da dissertação. 
Ainda neste sentido, os machinimas funcionam como um intertexto tanto do jogo quanto do fórum, pois parte expressiva de seus enredos vem de textos menos cristalizados encontrados nos fóruns (como os comentários), assim como o material visual e audível dos machinimas é oriundo tanto do próprio jogo, quanto dos materiais disponíveis nos jogos como GMod.

\subsection{Conclusões iniciais sobre os fóruns}

Após analisar acima as linguagens presentes nos fóruns, a partir do continuum memético proposto por Marino, esta pesquisa pode traçar algumas conclusões a respeito das dinâmicas dos fóruns presentes em nosso corpus. Ao esboçar as três categorias do continuum memético (Samples, Remixes e Remakes), Marino postula uma espécie de gradação entre elas:

Numa perspectiva estática, as três categorias sintáticas identificam formatos processuais e textos únicos. Numa perspectiva dinâmica, elas identificam as fases de um processo possível de produção hipertextual, no qual, de um texto fonte pré-pronto - é possível produzir o sample-remix textual, de onde surgirá o texto mimético. Cada um deles pode, por sua vez, servir como um texto pré-pronto propagável [...] além de estimular a produção e outro mashups (MARINO, 2018, p. 28)

Esta gradação entre as três categorias sintáticas possui convergências com uma outra gradação que, dentro do corpus analisado, tende a ocorrer num sistema similar: a gradação na cristalização dos tipos de debreagem enuncivas internas. Fiorin (2016) descreve a debreagem enunciva como "aquela em que se instauram no enunciado os actantes do enunciado (ele), o espaço do enunciado (algures) e o tempo do enunciado (então)" (FIORIN, 2016, p. 38). A debreagem interna, por sua vez, ocorre dentro da debreagem enunciva:

Trata-se do fato de um actante já debreado, seja ele da enunciação ou do enunciado, se torna instância enunciativa, que opera, portanto, uma segunda debreagem, que pode ser enunciativa ou enunciva. É assim por exemplo, que se constitui um diálogo: com debreagens internas, em que há mais de uma instância de tomada da palavra. (FIORIN, 2016, p. 39).

A importância da observação destas debreagens enuncivas seguidas de debreagens internas se deve ao efeito que elas podem causar. Fiorin compara os efeitos desta com a debreagem enunciativa, quando se instalam no enunciado os actantes (eu/tu), o espaço (aqui), e o tempo (agora): 
A debreagem enunciativa e a enunciva criam, em princípio, dois grandes efeitos de sentido: de subjetividade e de objetividade. Assim, a instalação dos simulacros do ego-hic-nunc enunciativos, com suas apreciações dos fatos, constrói um efeito de subjetividade. Já a eliminação das marcas de enunciação do texto, ou seja, da enunciação enunciada, fazendo que o discurso se construa apenas com enunciado enunciado, produz efeitos de sentido de objetividade. Como o ideal de ciência que se constitui a partir do positivismo é a objetividade, o discurso científico tem como uma de suas regras constitutivas a eliminação de marcas enunciativas, ou seja, aquilo a que se aspira no discurso científico é construir um discurso só com enunciados (FIORIN, 2016, p. 39).

Grosso modo, a debreagem enunciativa cria um efeito de "opinião", enquanto a debreagem enunciva cria um efeito de "fato". Esta dinâmica é reforçada pela debreagem interna, que "serve, em geral, para criar um efeito de sentido de realidade, pois parece que a própria personagem é quem toma a palavra e, assim, o que ouvimos parece ser exatamente o que ela disse" (FIORIN, 2016, p. 40).

Em todas as linguagens analisadas acima, observamos diversas debreagens enuncivas seguidas de debreagens internas: Narrações e travessões com falas nas fanfics, traços e cores que personificam as personagens nas ilustrações e memes, narrativas e balões nos quadrinhos e memes, e até programações de código que permite fazer com que as personagens movam-se e interajam nos machinimas.

Para os elementos meméticos analisados acima, auxilia em sua propagabilidade que o punctum barthesiano seja tratado como um "fato", pois a personagem retratada toma a palavra, e não apenas como a opinião de um perfil do fórum. Neste sentido, a debreagem enunciva seguida de uma debreagem interna colabora para este efeito.

Dito isto, é importante observar que a intensidade dos efeitos destas debreagens acaba por se correlacionar com o trabalho que exigem. Também no livro Astúcias da Enunciação, Fiorin cita como algumas das competências necessárias para a produção de um enunciado:

Competência textual, que concerne ao saber utilizar a semiótica-objeto em que o discurso será veiculado [...] competência intertextual, que se refere às relações contratuais ou polêmicas que um texto mantém com outros [...] competência situacional, que diz respeito ao conhecimento a respeito da situação em que se dá a comunicação e do parceiro do ato comunicativo (FIORIN, 2016, p. 28). 
Tais competências pressupõem um domínio dos meios e linguagens envolvidos, e tal domínio se torna mais exigente quando o discurso se torna sincrético. Um discurso na forma de um comentário dentro de um fórum, linguagem mais elementar de interação em tais espaços, exige de seu produtor apenas o conhecimento básico da linguagem em que se comunica, bem como os princípios básicos de funcionamento do fórum. À medida que a complexidade e sincretismo das linguagens aumenta, também aumenta a exigência do produtor para a confecção de discursos, como mostra a figura abaixo:

Figura 53 - Lista de competências para a produção de enunciados nas linguagens analisadas.

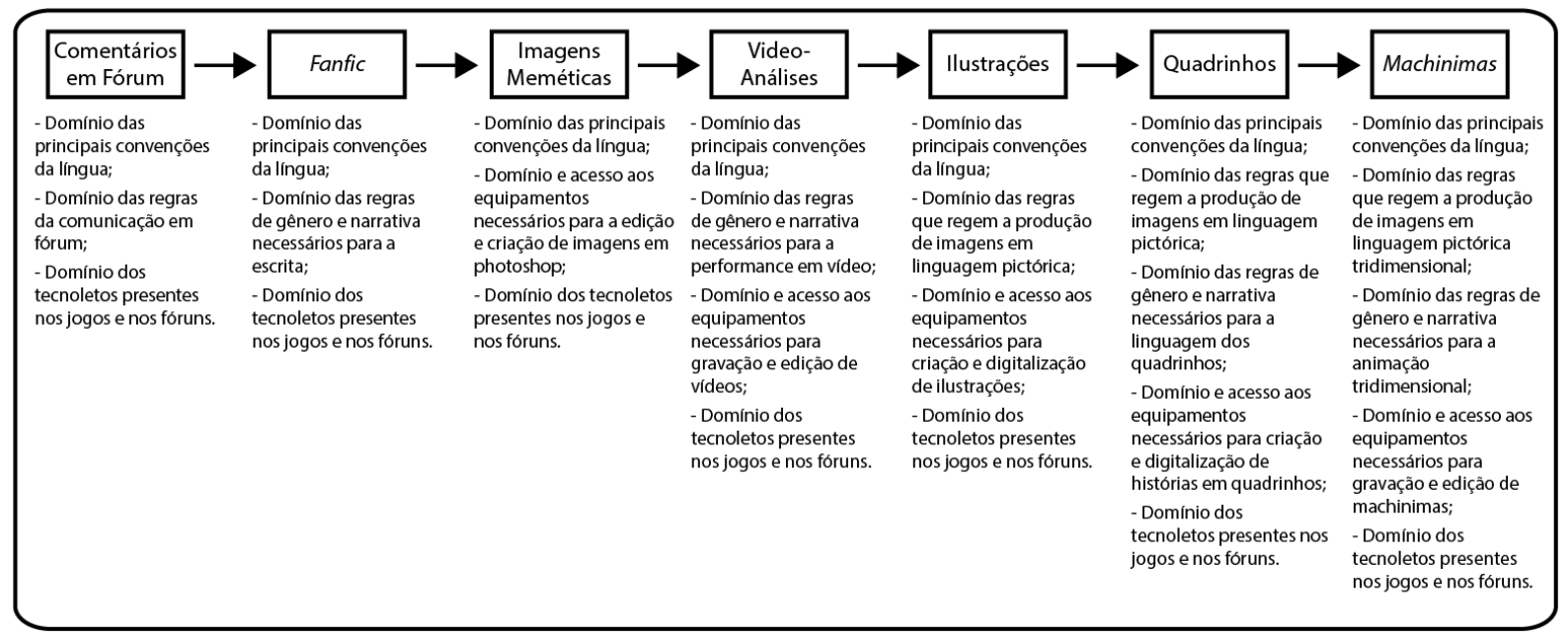

Fonte: imagem nossa.

O esquema apresentado acima não tem como função definir qualquer sorte de regras para a consideração das linguagens abordadas. Ela se propõe tão somente a enumerar as principais competências geralmente requeridas aos produtores do discurso para a enunciação em certas linguagens, e demonstrar que, quanto mais linguagens sincréticas são envolvidas, mais competências se fazem necessárias.

Por consequência, pode-se postular que, enquanto todo o usuário dos fóruns analisados é capaz de produzir discursos no formato de comentário de fórum, apenas alguns destes serão capazes de criar fanfics ou imagens meméticas, enquanto um número ainda menor será capaz de criar quadrinhos ou machinimas. 
Não surpreendente é o fato de que, dentro dos fóruns e, em especial nos fóruns de compartilhamento de imagens Danbooru e Rule 34, ocorre a prática de Comission (Comissão): Um usuário-cliente paga para que um usuário-artista produza uma peça de arte em alguma linguagem (ilustração, machinima etc.), seguindo as orientações do usuário-cliente.

Figura 54 - Exemplo de ilustração feita através de comissão.

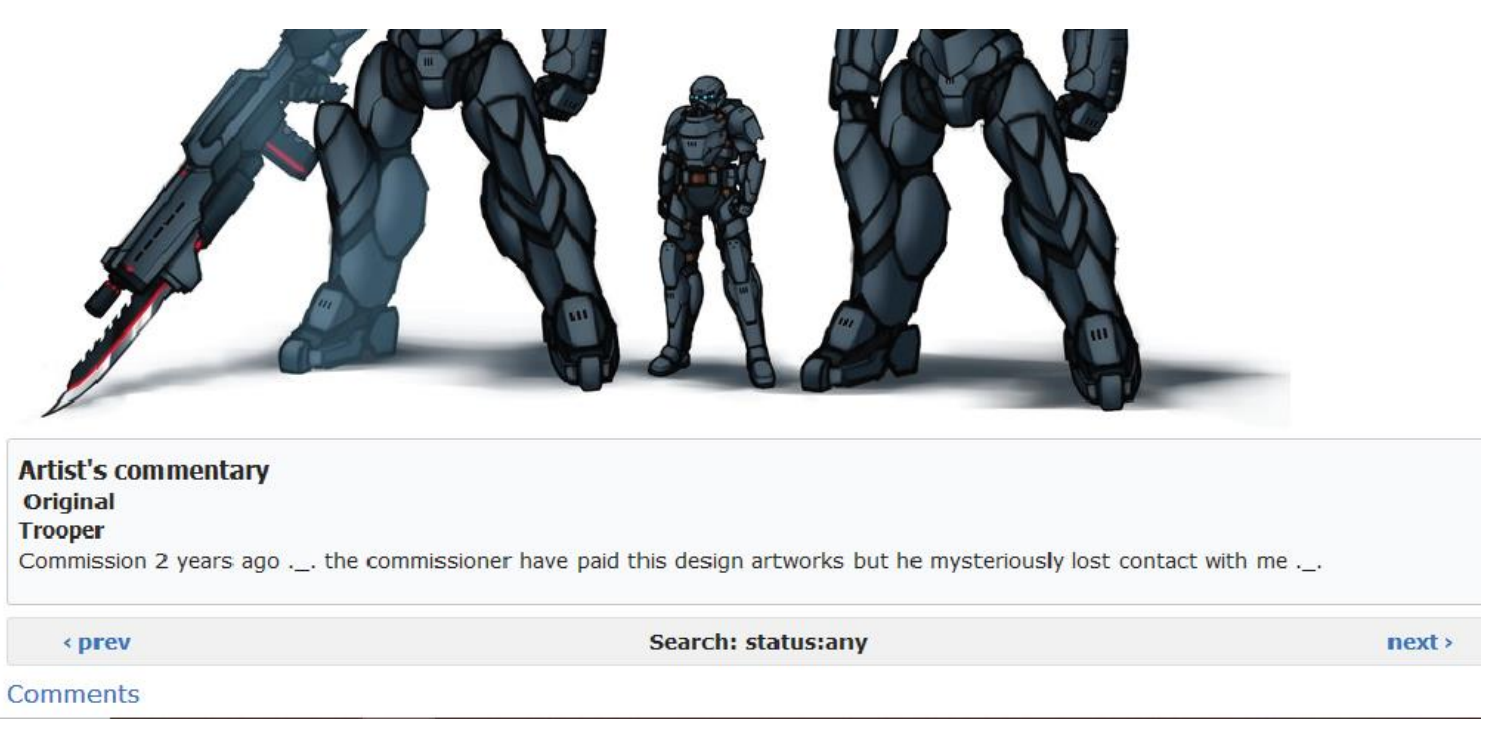

Fonte: Danbooru $(2020)^{144}$.

Uma das principais razões para tais comissões é a capacidade dos objetos de semiótica sincrética em cristalizarem o "efeito de real". Esta pesquisa não intenta propor que haja uma relação entre a complexificação das semióticas sincréticas e os processos de debreagem enunciva. Mas, dentro do processo de manifestação do continuum memético, estes dois fatores auxiliam nas estratégias de propagação.

Segundo Barthes, o punctum possui um caráter de autoria por parte do observador (spectator), pois "quer esteja delimitado ou não, trata-se de um suplemento: é o que acrescento à foto e que todavia já está nela" (BARTHES, 2015, p. 52). O punctum "fere" e perpassa o spectator pois fala diretamente com este, o clama a sentir além do que está presente na foto. Este elemento

\footnotetext{
${ }^{144}$ Disponível em: <https://danbooru.donmai.us/posts/4164430>. Acesso em: 10 mar. 2021.
} 
de autoria é o que Marino observa como função memética: algo que está no objeto, mas dá ao seu observador a sensação de autoria.

Porém, é necessário relembrar a constante observada por Jenkins, Green e Ford (2014), quando estes analisavam as estratégias de circulação de conteúdo nos meios de comunicação sociai e digital (que, incluem os fóruns, nosso corpus). Através da máxima "Se algo não se propaga, está morto." (JENKINS; FORD; GREEN, 2014, p. 23)., os autores afirmam que "a propagação, de todas as formas de mídia, depende tanto (ou mais) de sua circulação pelo público quanto de sua distribuição comercial; que a propagabilidade é determinada por processos de avaliação social e não técnica ou feitiçaria criativa, e com a participação ativa dos públicos engajados.” (Ibid., p. 244).

A partir disso, temos um punctum que, através da dinâmica memética, busca se propagar e se manter propagado e propagável, através de samples, remixes e remakes. Porém, a característica pessoal e autoral do punctum, inevitavelmente, se esvaece à medida que se torna acordado e esperado dentro da comunidade onde se propagou, compartilhada por grande parte dos seus membros. O punctum se torna, então, studium.

Barthes define o studium como um elemento que "transmite enfaticamente a 'realidade', sem duplicá-la, sem fazê-la vacilar: nenhum duelo, nenhum indireto, nenhum distúrbio" (BARTHES, 2015, p. 40). Tal efeito promovido pelo studium é resultado de uma educação e convenção social, algo que deve ser aceito e acordado entre os membros de uma comunidade. Esta pesquisa postula que, em sua existência pautada pela propagabilidade, o punctum memético pode se manter em expansão, até adquirir o estatuto de studium.

É aqui que as propostas deste estudo sobre o continuum memético e a debreagem enunciva se encontram. Á medida que um punctum memético se propaga o suficiente dentro de uma comunidade, ele passa a se multiplicar em samples, remixes e remakes, gradativamente se propagando em linguagens sincréticas (como ilustração, quadrinhos, machinima, vídeo), que possuem, via de regra, maior cristalização de suas debreagens enuncivas e debreagens internas. A presença dentro destas linguagens sincréticas garante também ao elemento memético uma maior ocorrência de ratio facilis que, de acordo com Eco (2014), tem como característica principal característica a concordância com sistemas expressivos e convenções socialmente aceitas. 
Todos estes elementos convergem em sua tarefa de criar efeitos de realidade, que podem até alçar um punctum memético individual à uma condição de studium culturalmente convencionado.

Um último ponto a ser destacado a respeito das relações aqui propostas se refere ao começo deste efeito de propagabilidade. Para que um punctum memético possa ser devidamente discursivizado e propagado coletivamente dentro dos fóruns de jogos, sua interpretação precisa ser devidamente polemizada e figurativizada. Esta pesquisa considera que o principal local onde estas atividades ocorrem é nos comentários escritos dos fóruns.

Ilustraremos esta proposta tomando como exemplo o meme boop relacionado à personagem Sombra de Overwatch, que foi apresentado anteriormente nesta pesquisa. O vídeo de apresentação da personagem, que possui o punctum memético "boop", foi publicado no youtube em 4 de novembro de 2016, durante o evento de lançamento da personagem na BlizzCon, convenção organizada pela empresa produtora do jogo.

Figura 55 - Primeiros comentários no vídeo de lançamento da personagem Sombra.

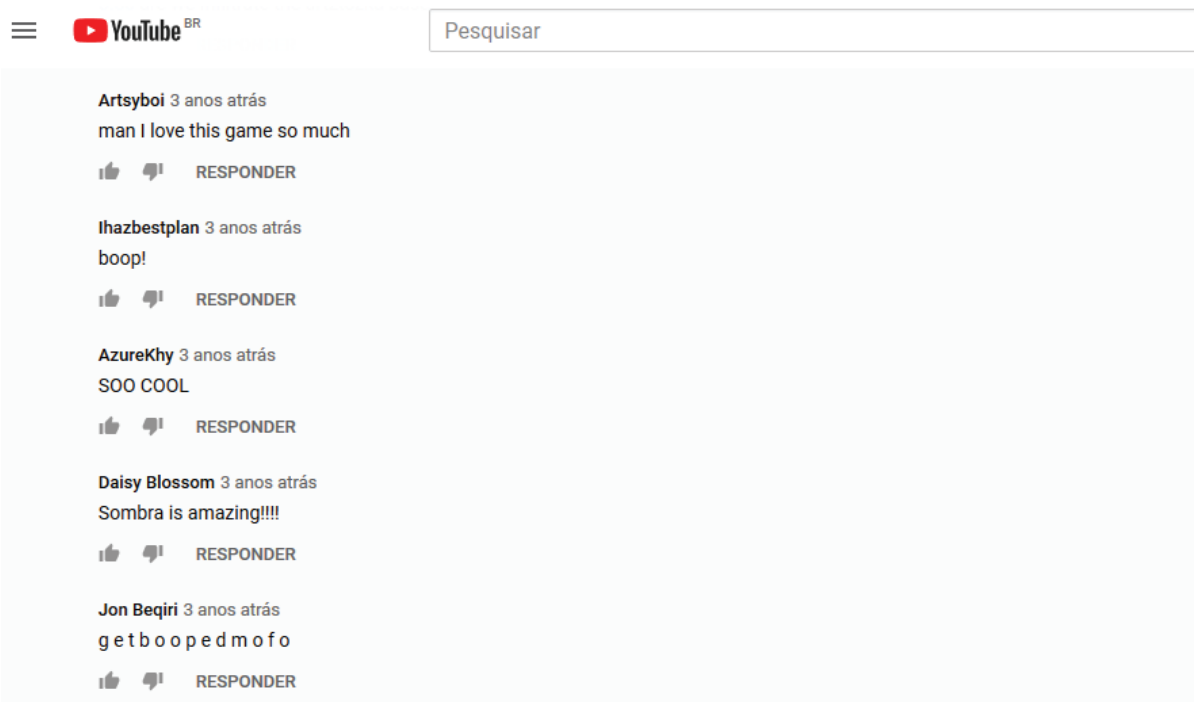

Fonte: Youtube $(2020)^{145}$.

${ }^{145}$ Disponível em: <https://www.youtube.com/watch?v=Og5-Pm4HNII>. Acesso em: 10 mar. 2021. 
Como apresentado na imagem acima, o primeiro e o quarto comentário no vídeo, feitos minutos após seu upload, já faziam menções ao punctum memético boop. A primeira imagem (ratio difficilis) a surgir na plataforma Danbooru ${ }^{146}$ quase simultaneamente. Porém, enquanto os comentários no Youtube continuavam expandindo a figurativização do punctum Boop (como popularizando o termo "booped!" como termo para um jogador derrotado pela personagem durante uma partida, ou a especulação que outro personagem do jogo, Lucio, já utilizava o termo "boop" anteriormente - o que gerou outros remixes-remakes), a segunda imagem com este tema no site Danbooru ${ }^{147}$, bem como a primeira imagem no site Rule $34^{148}$ (ambas ainda começando a demonstrar sinais de ratio facilis) saíram apenas no dia seguinte.

Os comentários escritos acabam por ser o principal espaço de negociação durante o processo de propagabilidade do punctum memético, primeiro por serem por excelência o que esta pesquisa chamou de sanção qualitativa (a sanção operada por discurso escrito), e segundo por serem o tipo de linguagem mais democrática dentro do espaço dos fóruns analisados. Esta pesquisa postula que, ainda que as demais linguagens possam oferecer peças com um efeito de realidade mais cristalizado, são os comentários que fornecem o ponto de partida, sendo a primeira estrutura polêmica, ajudando a circunscrever alguns dos desdobramentos nas demais linguagens.

Após realizada a análise semiótica das estruturas dos jogos e dos fóruns, o passo seguinte é a análise de algumas das estratégias discursivas que buscam estabelecer veridicções dentro destes ambientes.

${ }^{146}$ KADABURA. Post de imagem. Danbooru. Disponível em: <https://danbooru.donmai.us/posts/2533753>. Acesso em: 31 out. 2020.

147 DISHWASHER1910. Doodle: Boop War. Danbooru. Disponível em: <https://danbooru.donmai.us/posts/253 4866>. Acesso em: 31 out. 2020.

${ }^{148}$ MAGSAMA. Post de imagem. Rule 34. Disponível em: 〈https://rule34.paheal.net/post/view/2017335>. Acesso em: 31 out. 2020. 


\section{OBJETO TRÊS: O MACROTEXTO JOGO - FÓRUM}

\subsection{Recapitulação das conclus̃̃es iniciais}

Para a análise das estratégias de veridicção mais comuns utilizadas pelos enunciadores do fórum, cabe resgatar algumas conclusões prévias, levantadas durante a análise dos jogos $L O L \mathrm{e}$ Overwatch, bem como a análise das estruturas dos fóruns e o elemento do continuum memético.

Uma primeira conclusão, traçada no capítulo 2, diz respeito às razões pelas quais esta pesquisa optou por fazer dois estudos de corpus, os jogos e o fórum:

- Em função da relação sinérgica entre fórum e jogos, operacionalizada pelo uso do cybertexto, torna-se muito difícil observar as figuras, temas, isotopias e argumentos que compõe o fórum sem analisar o jogo (e, em menor medida, vice e versa). Portanto, esta pesquisa considerou que os dois corpus analisados (dois jogos e sete fóruns) oferece o nível ótimo de análise proposto por Greimas (1993) para a compreensão do texto.

- A dinâmica entre fóruns e jogos, nos moldes do trabalho de Pessoa de Barros (1988) é a de que Jogo e Fórum são textos-contexto situacionais um do outro, enquanto os textos-contextos interno e externo estão representados no que esta pesquisa denominou como "Manifestação Cultural Dominante", termo criado a partir da teoria de Canclini (2007) sobre a desigualdade dentro da esfera globalizada e digital.

No capítulo 1, quando esta pesquisa analisou os jogos $L O L$ e Overwatch, através do modelo proposto por Angelo (2015), as seguintes conclusões iniciais foram observadas:

- A sanção em $L O L$ e Overwatch é parcial. Enquanto o desempenho e a competência do jogador são sancionados cognitiva e pragmaticamente, dentro do modelo semiótico tradicional, a narrativa das personagens que o jogador utiliza para jogar, numa homologação parcial entre jogador e personagem, não é sancionada. Do ponto de vista do jogar como processo narrativo, foi observado, a partir de Razzino Ernica (2014) e Murray (2003), que os dois jogos de videogames analisados possuem uma estética da incompletude, em que o 
fechamento ocorre pela saturação dos princípios de imersão, agência e transformação, e substitui a sanção narrativa, permitindo que o jogador "conclua" sua experiência do jogar. Já do ponto de vista das narrativas do elenco de personagens do jogo, a ausência de sanção às performances das personagens acaba por ocultar as preferências ideológicas do enunciador. Esta ausência de sanção, decorrente da estética da incompletude, incentiva os jogadores e fãs a buscar tal saturação (em relação ao universo narrativo do jogo) nos ambientes de fórum.

- A partir dos princípios de igualdade lúdica, levantados por Huizinga (2014), Caillois (1990) e Salen \& Zimmerman (2016), LOL e Overwatch se utilizam de diversas isotopias, tanto no plano do jogo quanto no plano nas narrativas, para criar um ambiente polêmico que incentive o embate justo entre competidores. As principais isotopias identificadas nesta pesquisa foram:

- $\quad$ Isotopia da Igualdade - No plano do jogo, graças a ferramentas como o modelo de Flow de Cziksentmihalyi (2008) ou à Triangularidade descrita por Juul (2019), o jogo produz uma igualdade dinâmica, em que cada vez que uma tática de jogo desequilibra as partidas por muito tempo, Patches são criados para corrigir tal diferença. No plano das narrativas, todas as personagens do elenco possuem um percurso narrativo próprio e igualmente desenvolvido, no qual são apresentados como sujeitos atualizados e competentes, e em confronto com outros sujeitos com programas opostos, gerando assim ligações polêmicas entre programas e anti-programas, impedindo que certos personagens se configurem protagonistas ou antagonistas no jogo em definitivo.

- Isotopia da Totalidade/Globalidade - A partir de observações de Rosenfeld (2014), Cândido (2014), Todorov (2017) e Eco (2017), a respeito do caráter hermético e simbológicos dos universos e personagens de ficção, bem como a inevitabilidade de metáforas entre o mundo da ficção e o "mundo das coisas", o jogo busca criar um universo fictício que possua a representatividade global do mundo das coisas. Os desenvolvedores buscam criar mundos que mimetizem conflitos sociais e políticos do mundo de seus fãs e jogadores, bem como personagens que possuam a diversidade de gênero, cor, biotipo e sexualidade, ao mesmo tempo que agradem à comunidade 
de jogadores e incentivem a compra de passes e merchandising (com diversos graus de sucesso).

Por fim, vale lembrar que este "Mundo das coisas" não é ontológico, mas uma leitura enviesada, recorrente no discurso do ambiente digital, e nomeado nesta pesquisa como Manifestação cultural dominante, a partir das observações de Canclini (2007).

No capítulo 3, quando esta pesquisa levantou alguns princípios de organização dos fóruns que irão compor o segundo corpus de análise, já se valeu de alguns estudos sobre o objeto na própria área da semiótica:

- Do ponto de vista do objeto, os 7 fóruns listados como corpus são endereços digitais que se utilizam de maneira intensa da construção de sentido através da leitura de cybertextos, um sistema de leitura que propõe que tais fóruns sejam entendidos como uma totalidade de sentido a ser lida de maneira ergódica, como proposto por Aarseth (1997).

- Outras características importantes dos fóruns analisados são: a junção de diversos perfis que compartilham de $L O L$ ou Overwatch como interesse em comum; a existência de moderadores que administram e censuram assuntos que saiam do tema do fórum ou ultrapassem o limite da civilidade; o uso de perfis fantasiosos e pseudônimos; a assincronia entre troca de mensagens; o desenvolvimento de diversos tecnoletos e a tendência ao uso do inglês; o suporte de elementos multimídia; e também a comunicação em períodos mais curtos e com nominalizações, segundo observações de Marcuschi (2009).

- Relativo à forma da expressão multimídia do fórum, a análise do corpus a partir dos estudos sobre continuum memético proposto por Marino (2018) concluiu que o elemento que caracteriza a propagabilidade dos memes, análogo ao punctum de Barthes (2015), possui como característica um efeito de participação na construção do efeito de verdade de um discurso.

Para auxiliar neste movimento, existem as dinâmicas de apreensão das linguagens com elementos visuais, via a ratio facilis e ratio difficilis proposto por Eco (2014), e retomado por Fraenza (2017). Há também a utilização, nas linguagens com elementos 
textuais, de debreagens enuncivas e debreagens internas, nos moldes do proposto por Fiorin (2016).

- Os dois movimentos analisados permitem a potencialização da propagabilidade memética do punctum de um discurso: através dos comentários textuais, unidade mais elementar e democrática dentro do fórum, perfis podem trabalhar ativamente para a propagação (de maneira coletiva), e quando tal punctum começa a ser trabalhado em samples, remixes e remakes utilizando linguagens sincréticas, o menor número na ocorrência de discursos é compensado pela maior cristalização do efeito de verdade, objetivo político e ideológico do discurso.

Por fim, no capítulo 3 também foram levantadas algumas considerações a respeito das denominações das estruturas discursivas a serem analisadas dentro do fórum. A partir do modelo de estudo do nível discursivo de Pessoa de Barros (1988), os atores da enunciação são considerados da seguinte forma:

- $\quad$ No percurso da comunicação, o enunciador é um perfil, que se comunica com um enunciatário que, mesmo que nomeado como um outro perfil, é na verdade dirigido à comunidade como um todo, dada a natureza hiperpessoal e simultânea do fórum. Tal dinâmica é conhecida e aceita por todos os demais perfis, por isso esta pesquisa também assume que o julgador dessa comunicação acaba também sendo o coletivo da comunidade, que possui a prerrogativa de interferir nas interações de um perfil, sancionando-o positiva ou negativamente

- No percurso da produção, enquanto os sujeitos da enunciação são os perfis, o produtor do discurso e seus valores ideológicos é um operador, responsável pela construção e operação dos perfis, cabendo ao resto da comunidade o papel de receptor de tais discursos e valores ideológicos.

A respeito ainda dos percursos do nível discursivo, outras primeiras conclusões já puderam ser esboçadas:

- Existem dois tipos de sanção complementares, disponíveis no ambiente dos fóruns: a sanção qualitativa e a sanção quantitativa. Esta última, representada por likes 
(curtidas), será considerada como um elemento de sanção, mas não será analisada em profundidade. A sanção qualitativa será considerada como respostas e comentários feitos por outros perfis, que geram anti-programas narrativos, com anti-destinadores e anti-sujeitos, explicitando a natureza polêmica dos discursos, descrito por Pessoa de Barros (1988). Este segundo tipo de sanção será analisado com mais detalhes neste capítulo.

Após recapitular as considerações levantadas incialmente na descrição e análise dos jogos, bem como na descrição dos fóruns, procede-se agora a analisar algumas recorrências de estratégias veridictórias encontrados dentro do corpus de fóruns analisados. Os pontos levantados aqui são escolhidos, como descrito na introdução deste trabalho, por serem pontos nevrálgicos desses ambientes, e por possuírem relações com os demais itens abordados anteriormente, constituindo um panorama inicial de possibilidades sobre o assunto, e não uma teoria completa e cristalizada. Inicialmente, serão abordados os elementos sintáxicos.

\subsection{Elementos sintáxicos do discurso em fórum}

\subsubsection{O humor e a ambiguidade}

O humor é um elemento recorrente nos discursos das redes sociais, e não é diferente no espaço de fórum. Norma Discini, ao analisar semioticamente o blog de humor Kibeloco, aponta o caráter marcante da presença da sátira e do humor grotesco no estilo do enunciador Kibeloco. Para tal afirmação, a autora se vale do livro A cultura Popular na Idade Média e no Renascimento: $O$ Contexto de François Rabelais, do teórico literário russo, Mikhail Bakhtin.

Ao analisar os elementos da comédia e do grotesco utilizados pelo escritor François Rabelais (1494 - 1553) que criou Gargantua e Pantagruel, Bakhtin faz um levantamento de como o riso e o humor popular eram tratados durante a idade média europeia (material de referência do autor) e no renascimento (período em que sua obra foi desenvolvida e se popularizou), e chega a postular como tais mudanças interferiram na noção moderna do humor ocidental. 
Numa sumarização, Bakhtin afirma que o riso da cultura popular da Idade Média europeia (Festas dos loucos, carnavais, canções) é oriundo de uma “divisão" social relativa ao período. Os eventos sociais, como missas, relações hierárquicas e feudais, possuíam toda a pompa e seriedade tradicionalmente associadas ao período. Mas a crença da época, da "necessidade de criar uma válvula de escape para a 'segunda natureza humana' (o riso)" (BAKHTIN, 1987, p. 65), permitia que a população da idade média tivesse uma "segunda vida", de bufa e riso, que embora apartada de toda a "vida oficial" medieval, possuía uma estrutura ritualística e oficial tão sólida quanto esta.

Tal "segunda vida" das festas e folguedos era quase que um espelho grotesco da vida medieval: possuía suas próprias missas e orações, suas próprias bulas e livros, seus próprios poemas e hierarquias. Ao contrário porém, da busca pelos valores espirituais, castos e obedientes da Idade Média, estas práticas da "segunda vida" celebravam o mundo "de baixo", o grotesco do ser humano:

Em oposição aos cânones modernos, o corpo grotesco não está separado do resto do mundo, não está isolado, acabado nem perfeito, mas ultrapassa-se a si mesmo, franqueia seus próprios limites. Coloca-se ênfase nas partes do corpo em que ele se abre ao mundo exterior, isto é, onde o mundo penetra nele ou dele sai ou ele mesmo sai para o mundo, através de orifícios, protuberâncias, ramificações, e excrescências, tais como a boca aberta, os órgãos genitais, seios, falo, barriga e nariz. É em atos tais como o coito, a gravidez, o parto, a agonia, o comer, o beber e a satisfação de necessidades naturais, que o corpo revela sua essência como princípio em crescimento que ultrapassa seus próprios limites. É um corpo eternamente incompleto. (BAKHTIN, 1987, p. 23)

Esta "segunda vida" do cômico e grotesco medieval, pautada pelas reações corporais do mundo de baixo, possuía um gracejo e um folguedo para cada elemento da "vida oficial", sobre de quem se ria e sobre quem ria. Uma espécie de riso que congregava todos os segmentos dentro da festa.

Existe, portanto, a possibilidade de que todos os elementos de poder e prestígio da sociedade medieval tenham uma leitura a partir do "mundo de baixo", e esta leitura não acarreta uma punição, pois existe fora dos canais oficiais. A este fenômeno Bakhtin chama de riso libertador: o riso que permite a transformação dos agentes da opressão em "espantalhos", por congregar todos os extratos sociais dentro da celebração do "mundo de baixo", permitindo assim um renascimento, uma espécie de recomeço das relações do mundo oficial. 
Durante o período da Idade Média, as críticas feitas dentro dessa "segunda vida" eram de um certo modo genéricas. "Não somente não faz nenhuma exceção ao estrato superior, mas ao contrário, dirige-se principalmente contra ele. Apesar disso, ele não é dirigido contra um caso particular ou uma parte, mas contra o todo, o universal, o total”. (BAKHTIN, 1987, p. 76). Essa noção se mostra de acordo com a sociedade medieval, fortemente pautada por hierarquias e pela religião, em que as funções sociais eram mais importantes que os indivíduos que as exerciam. Ainda sobre isso, diz o autor:

Como o drama satírico da Antiguidade, a cultura cômica da Idade Média era em grande medida o drama da vida corporal (coito, nascimento, crescimento, alimentação, bebida, necessidades naturais), não, porém, do corpo individual nem da vida material particular, mas sim do grande corpo popular da espécie, para o qual o nascimento e a morte não eram nem o começo nem o fim absolutos, mas apenas as fases de um crescimento e uma renovação ininterruptos. (BAKHTIN, 1987, p. 76).

O desenvolvimento do renascimento europeu, porém, altera algumas das características desse humor popular. Primeiramente, alguns elementos da cultura popular medieval, como os personagens de Rabelais e procissões e fogos de artifício, são incorporados às festas da corte, em função dos poetas conhecedores de tais tradições medievais serem pagos pela corte para a produção de tais festividades. Essa apropriação dos motivos medievais do "mundo de baixo" acaba por necessitar de algumas degenerescências estilísticas: o grotesco medieval começa a se apresentar como burlesco.

Paralelo a esse acontecimento, o surgimento do humanismo dentro da cultura renascentista acaba por alterar as bases em que a comédia popular se assentava. Se antes o ser humano era visto como uma dualidade entre uma imagem oficial e séria e uma imagem bufa e cômica (sendo ambos perfeitamente coexistentes na moral medieval), no renascimento o foco e o estudo sobre o indivíduo gera uma nova concepção de moralidade. No Renascimento, não há mais a divisão entre o mundo oficial e o mundo do humor, mas este é absorvido pelos bailes da corte, pela literatura e por outros canais oficiais. Este período histórico humanista também vê o ser humano como perfeito, acabado e completo; portanto sua apresentação como grotesco e bufo já não pode mais ser tolerado como natural. Nas palavras de Bakhtin:

A degeneração do princípio cômico que organiza o grotesco, a perda de sua força regeneradora suscitam novas mudanças que separam mais profundamente $o$ 
grotesco da Idade Média e do Renascimento do grotesco romântico. As mudanças mais notáveis ocorrem com relação ao terrível. O universo do grotesco romântico se apresenta geralmente como terrível e alheio ao homem. Tudo o que é costumeiro, banal, habitual, reconhecido por todos, torna-se subitamente insensato, duvidoso, estranho e hostil ao homem. O mundo humano se transforma de repente em um mundo exterior. O costumeiro e tranquilizador revela seu aspecto terrível. Tal é a tendência do grotesco romântico (nas suas formas extremas, mais prototípicas), A reconciliação com o mundo, quando se realiza, ocorre em um plano subjetivo e lírico, às vezes mesmo místico. Ao contrário, o grotesco medieval e renascentista, associado à cultura cômica popular, representa o terrível através dos espantalhos cômicos, isto é, na forma do terrível vencido pelo riso. [...] As imagens do grotesco romântico são geralmente a expressão do temor que inspira o mundo e procura comunicar este temor aos leitores (aterrorizálos). (BAKHTIN, 1987, p. 34).

Após os desenvolvimentos humanistas do Renascimento, o que corrompe o homem perfeito é visto como uma profanação destrutiva, ao qual só cabe o escárnio ou a expulsão. A moralização do cômico assume formas punitivas e julgadoras. O riso popular que antes era visto como a exacerbação de uma "segunda natureza" do mundo e, portanto, componente deste, passa a ser uma força que combate os vícios e as degenerações do homem perfeito. Passa-se a crer que apenas certas coisas devem ser matéria de riso.

Esta tendência se solidifica no decorrer dos séculos seguintes, e Bakhtin observa que seu estudo sobre o olhar à cultura medieval a partir dos valores da época, difere "das teorias e filosofias do riso posteriores, como a de Bergson, que acentuam de preferência suas funções denegridoras" (BAKHTIN, 1987, p. 61).

A obra a qual Bakhtin se refere é O Riso: Ensaio sobre o significado do cômico, que reúne três artigos do filósofo francês Henry Bergson a respeito do tema, e publicados em 1900. Segundo Bakhtin, a abordagem de Bergson sobre o tema do riso é um exemplo da leitura romântica e moderna sobre o cômico e o grotesco. Enquanto não cabe a esta pesquisa um aprofundamento na filosofia de Bergson ${ }^{149}$, sua tratativa sobre o riso e o cômico apresenta elementos importantes para o assunto aqui abordado.

${ }^{149}$ A filosofia de Bergson, independentemente de seu valor para outros campos de estudo, trabalha com pressupostos teóricos que postulam a existência de uma totalidade ontológica de sentido por trás da linguagem, que apenas apresenta (ou esconde). Tais pressupostos são incompatíveis com a Semiótica Greimasiana, não podendo portanto ser levada em consideração nesta pesquisa. 
O autor francês afirma que o riso é fundamentalmente uma função de correção social. Algo pensado para corrigir os defeitos sociais (chamados pelo autor de mecânico e rígido, em oposto ao orgânico e fluído da vida humana):

O que a vida e a sociedade exigem de cada um de nós é uma atenção constantemente alerta, capaz de discernir os contornos da situação presente, e também certa elasticidade do corpo e do espírito, pela qual possamos nos adaptar a ela. Tensão e elasticidade, eis duas forças complementares entre si, colocadas em ação pela vida. O corpo carece em grande medida delas? Seguem-se os acidentes de todos os tipos, as deformidades, a doença. Faltam ao espírito? Seguem-se todos os graus de pobreza psicológica, todas as variações de loucura. Ao caráter, por fim? Temos as profundas inadaptações à vida social, fonte de miséria e, por vezes, de crime. [...] Toda rigidez de caráter, de espírito e, mesmo, do corpo será, portanto, suspeita para a sociedade, uma vez que pode ser o sinal de uma atividade que adormece e, também, de uma atividade que se isola, que tende a se afastar do centro comum ao redor do qual a sociedade gravita, de uma excentricidade, enfim. Neste caso, no entanto, a sociedade não pode intervir com uma repressão material, uma vez que ela não é atingida materialmente. Ela se vê em presença de algo que a preocupa, mas apenas enquanto sintoma - quase uma ameaça, no máximo um gesto. Será portanto com um simples gesto que ela responderá. O riso deve ser algo desse gênero, uma espécie de gesto social. Pelo temor que inspira, reprime as excentricidades, mantém em constante alerta e em contato recíproco determinadas atividades de ordem acessória que correriam o risco de se isolar e se entorpecer, dá maleabilidade, enfim, a tudo o que pode subsistir de rigidez mecânica na superfície do corpo social (BERGSON, 2018, p. 44-45).

Estas excentricidades são destrinchadas por Bergson no decorrer do livro: sonhadores, exaltados e loucos que "correm atrás do ideal e tropeçam nas realidades" (p. 42), possuidores de deformidades, mas não das que inspiram pena, mas "deformidades que uma pessoa bem conformada for capaz de imitar" (p. 46), pois estas possuem a mesma função de uma caricatura. A mesma lógica se aplica aos bonecos e os jogos, elementos que circulam entre o humano e o mecânico. Bergson inclusive descreve as falhas de caráter e os vícios como uma "deformidade da alma" (p. 42).

Pensando no "mundo de baixo" de Bakhtin, a interpretação de Bergson se encaminha para uma moralidade maior. Para ele, tais elementos são manifestações que expõe defeitos da alma: a obesidade e a distração se apresentam como reflexos de vícios e defeitos. Parte fundamental deste efeito de cômico, segundo Bergson, se deve ao fato de que o cômico se volta para a inteligência, não ao sentimento. 
Ainda que, para uma leitura contemporânea, tais observações possam parecer insensíveis, Bergson argumenta que o riso é uma faculdade da inteligência pura: caso o objeto do riso "me for apresentado de modo a despertar minha simpatia, ou meu temor, ou minha piedade, está tudo acabado, não conseguirei rir dele” (BERGSON, 2018, p. 98). Estratégias como a transformação do alvo do riso em uma caricatura, e o foco do riso nos gestos dos alvos ao invés de suas intenções (ações) ajudam a criar o território do riso: “Insociabilidade da personagem, insensibilidade do espectador, eis, em resumo, as duas condições essenciais" (Ibid, p. 101).

A apresentação, nesta pesquisa, destas duas leituras do humor e do riso (o riso regenerador de Bakhtin e o riso corretor de Bergson) não busca uma oposição direta entre os dois, ou ainda uma moralização de uma ou outra forma de interpretação do riso. Como bem observou Norma Discini, durante seu estudo do corpo do enunciador do site Kibe Loco:

Se, nas charges levadas a cabo no blog há uma ambiguidade própria do humor, há também nelas uma sombra, tênue, embora de um riso carnavalesco. Mas essa sombra tende a dissipar-se no movimento de construção do sentido próprio à sátira, caracterizada como crítica com alvo certeiro e como o que cobra julgamento moral e posicionamento na instância da enunciação (DISCINI, 2015, p. 11)

Esta ambiguidade do humor, que pode levar ao riso regenerador bakhtiniano ou ao riso corretor bergsoniano, e que possui estes dois polos em constante tensão e disputa é o que interessa a esta pesquisa, referente ao comportamento de fórum em relação ao cômico e ao humor. A escolha da discursivização do humor com base em cada uma destas chaves é uma escolha ideológica dos enunciadores, como podemos ver nos exemplos a seguir.

Figura 56 - Comentário extraído do site Reddit. 


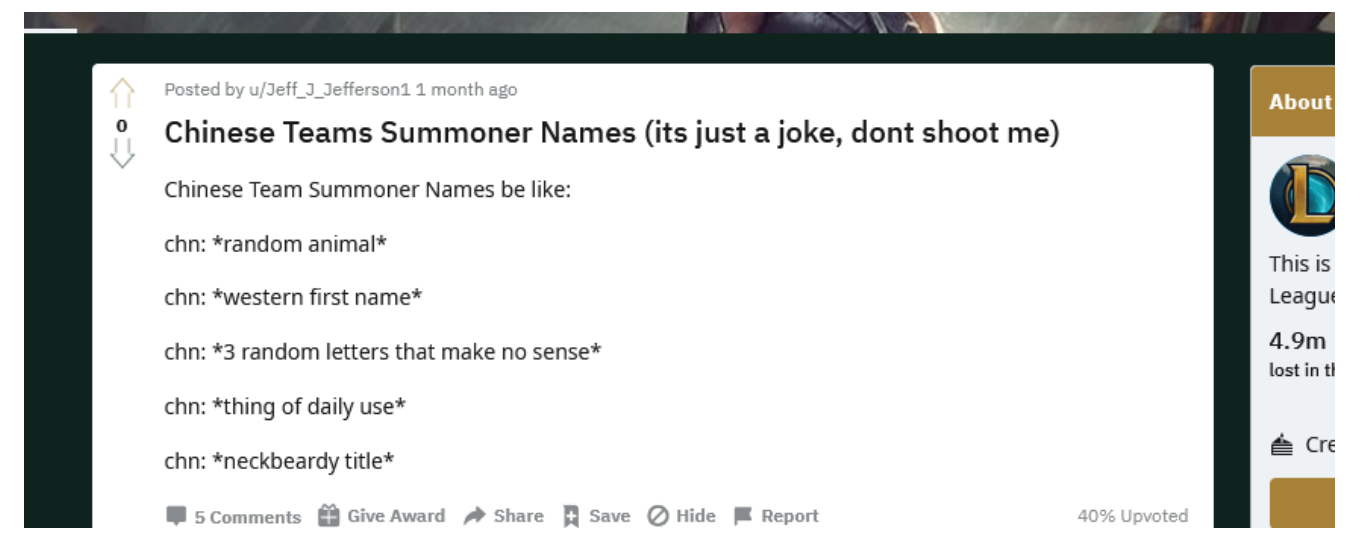

Fonte: Reddit $(2020)^{150}$.

$\mathrm{Na}$ imagem acima, o título da postagem traduz-se como "Nomes de times chineses de invocadores (é apenas uma piada, não atirem em mim)". Neste post ${ }^{151}$, o perfil enunciador Jeff_J_Jefferson propõe convenções imaginárias a respeito dos nomes dos perfis de jogadores chineses de LOL (chamados de invocadores dentro do tecnoleto do jogo), porém, reforça em seu próprio discurso que isto é apenas uma piada, pedindo que seus destinatários não o repreendam. Esta insistência em definir um discurso próprio ou de outro como "apenas uma piada" apresentase como um exemplo do uso do humor dentro da chave bakhtiniana do riso regenerador: o teor da piada é apresentado como um exemplar da "segunda vida de baixo", presente em todos os elementos da vida oficial, e portanto como uma proposta de riso regenerador.

Na imagem abaixo, vemos outro exemplo:

Figura 57 - Comentário extraído do site Youtube.

${ }^{150}$ Disponível em: <https://www.reddit.com/r/leagueoflegends/comments/jbkabg/chinese>. Acesso em: 10 mar. 2021.

151 JEFFERSON, Jeff J. Chinese Teams Summoner Names (its just a joke, dont shoot me). Reddit. Disponível em: <https://www.reddit.com/r/leagueoflegends/comments/jbkabg/chinese >. Acesso em: 13 dez. de 2020. 


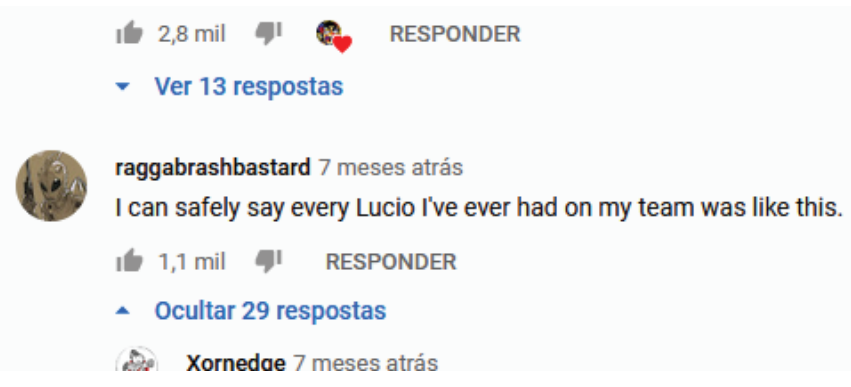

Fonte: Youtube $(2020)^{152}$.

Nesta imagem, o post do perfil raggabrashbastard se refere a um vídeo ${ }^{153}$ satírico do youtube que apresenta a personagem Lúcio, de Overwatch, como um colega de time incompetente, tradução do post do perfil é "Eu posso seguramente dizer que todos os Lúcios que já tive no meu time eram assim". Aqui nós temos um exemplo de riso corretor bergsoniano: a partir da piada que demonstrava um uso incompetente da personagem Lúcio, o perfil que postou o comentário acima postula que tais defeitos são uma característica de jogadores que usam tal personagem. Em resposta ao comentário apresentado acima, outro perfil fez a seguinte postagem:

Figura 58 - Comentário extraído do site Youtube.

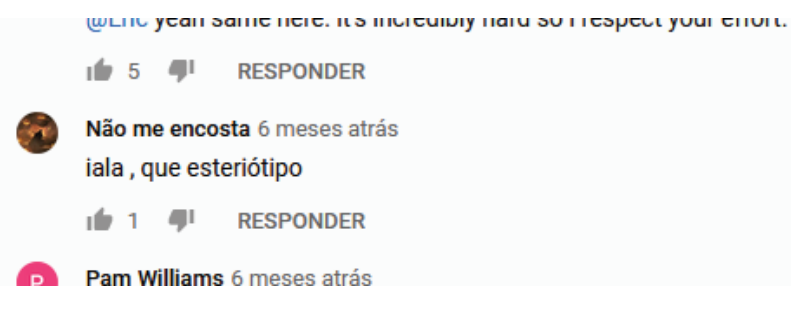

Fonte: Youtube $(2020)^{154}$.

No comentário apresentado acima, o perfil não me encosta percebe a moralização proposta e tenta sancioná-la negativamente ${ }^{155}$. Em outras ocasiões, as interpretações bakhtinianas e

152 Disponível em: <https://www.youtube.com/watch?v=RHFpl6ASZcg>. Acesso em: 10 mar. 2021.

153 DOPA TWO. Teammate Lucio (Overwatch Animation). Youtube. Disponível em: <https://www.youtube.com/ watch?v=RHFpl6ASZcg>. Acesso em: 14 dez. 2020.

${ }^{154}$ Disponível em: <https://www.youtube.com/watch?v=RHFpl6ASZcg>. Acesso em: 10 mar. 2021.

155 É interessante notar que o perfil que critica o comentário anterior escreve em português, e o personagem Lúcio, do universo de Overwatch, é brasileiro. As interpretações para este tipo de relação serão aprofundadas mais à frente neste capítulo. 
bergsonianas deste riso se alternam em uma mesma thread de postagens. No exemplo abaixo, há uma thread de discussão sobre uma ilustração ${ }^{156}$, na qual há uma piada que envolve atividade sexuais com uma personagem de 18 anos. Os seguintes comentários foram feitos:

Figura 59 - Comentário extraído do site Reddit.

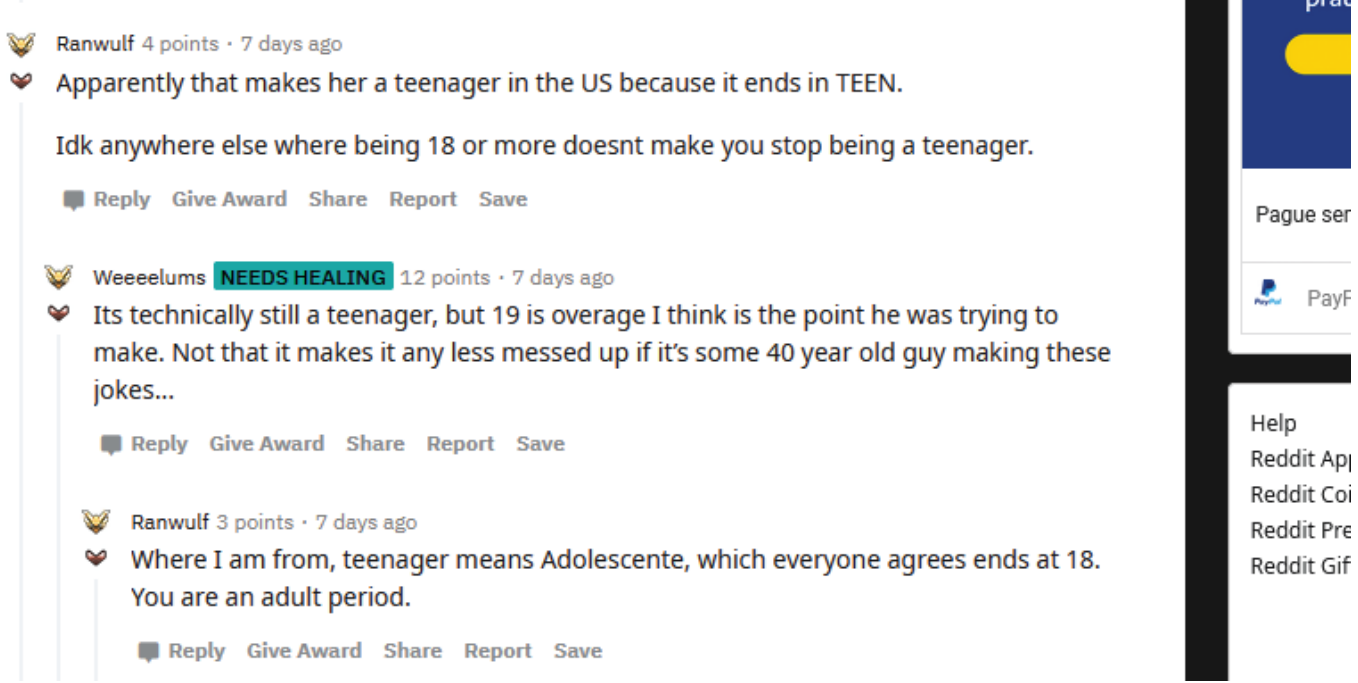

Fonte: Reddit $(2020)^{157}$.

Os perfis Ranwulf e Weeeelums fazem os seguintes comentários:

- “Aparentemente isso faz dela uma adolescente nos Estados Unidos porque termina em TEEN (eighteen). Eu não conheço nenhum lugar onde ter 18 ou mais não faz você parar de ser um adolescente.” (Ranwulf)

- “Tecnicamente ela ainda é uma adolescente, mas 19 já é maior de idade, e acho que esse era o ponto que o cara estava tentando fazer. Não que isso faça ser menos zoado se fosse um cara de 40 anos fazendo essa piada" (Weeeelums)

${ }^{156}$ BIG BAD BRAD 456. Perfect Timing. Reddit. Disponível em: <https://www.reddit.com/r/Overwatch_Memes /comments/k9oyao/perfect>. Acesso em: 14 dez. 2020.

157 Disponível em: <https://www.reddit.com/r/Overwatch_Memes/comments/k9oyao/perfect〉. Acesso em: 10 mar. 2021. 
- 'De onde eu venho, teenager significa 'adolescente', o que todo mundo concorda que acaba aos 18. Você é um adulto e ponto.” (Ranwulf)

Nesta conversa, Ranwulf argumenta que o uso do sufixo teen pelos americanos deixa em dúvida se uma mulher de 18 anos pode ser considerada menor de idade, enquanto o usuário Weeeelums intui que, mesmo que ela seja maior de idade, não retira o teor imoral do comentário se feito por, por exemplo, um homem de 40 anos. Mais abaixo, surge outro perfil, buttcontroversy, que responde aos comentários de Ranwulf:

Figura 60 - Comentário extraído do site Reddit.

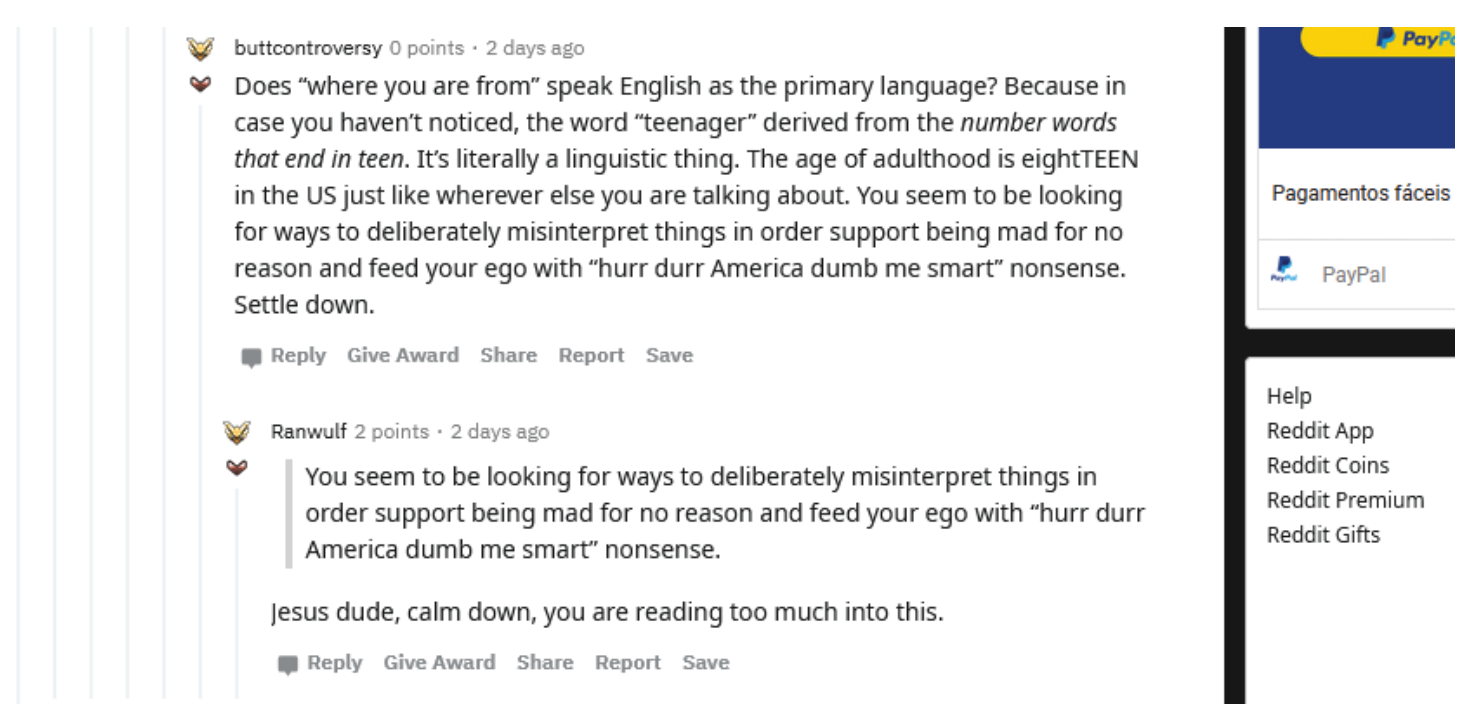

Fonte: Reddit $(2020)^{158}$.

O primeiro comentário, do usuário buttcontroversy pode ser traduzido como "Por acaso 'de onde eu venho' se fala inglês como primeira língua? Porque caso você não tenha notado, a palavra 'teenager' deriva dos numerais que terminam em teen. É literalmente uma coisa de linguística. A idade para maioridade é dezoito (eightEEN) nos Estados Unidos exatamente como em onde você está. Você parece estar procurando por maneiras de interpretar errado as coisas, como desculpa pra ficar bravo sem motivo e afagar seu ego com uma baboseira de "duh americanos ser burros e nós

158 Disponível em: <https://www.reddit.com/r/Overwatch_Memes/comments/k9oyao/perfect〉. Acesso em: 10 mar. 2021. 
ser espertos”. Para com isso.” Logo abaixo, Ranwulf apenas responde (através de uma citação direta) “Jesus cara, se acalma, você tá lendo coisa demais aqui”.

Num primeiro momento, podemos postular que as piadas que circulam nos fóruns possuem a possibilidade de serem interpretadas tanto a partir do modelo bakhtiniano quanto do modelo bergsoniano, e as próprias interpretações sobre as piadas podem ser sobre-interpretadas dentro deste eixo.

Já que o discurso em fórum está sendo considerado nesta pesquisa como a sequência de diversos discursos que possuem relação metatextual entre eles, a sucessão de interpretações do humor sob as chaves bergsoniana e bakhtiniana de leitura acabam por exercer uma função de reforçar ou diminuir, respectivamente, uma axiologia que compõe um discurso.

Comentários como o de Jeff_J_Jefferson ("é apenas uma piada, não atirem em mim") e Ranwulf ("Jesus cara, se acalma, você tá lendo coisa demais aqui") se apresentam como interpretações que visam diminuir a força de uma axiologia proposta (Chineses/disfórico $x$ Estrangeiros/eufórico e Americanos/disfórico x Estrangeiros/eufórico, respectivamente).

Já em comentários como os de raggabrashbastard ("posso seguramente dizer que todos os Lúcios que já tive no meu time eram assim”), e buttcontroversy (uma baboseira de 'duh americanos ser burros e nós ser espertos"”) se apresentam como interpretações que buscam recrudescer uma axiologia proposta (jogadores que jogam com lúcio/disfórico $x$ demais jogadores/eufórico e americanos/disfórico x estrangeiros/eufórico, respectivamente).

A importância desta contatação, no contexto deste trabalho, é a importância da oposição axiológica dentro da atividade da sanção. Segundo Greimas \& Courtés (2008) a sanção pragmática:

É um juízo epistêmico, proferido pelo Destinador-julgador sobre a conformidade dos comportamentos e, mais precisamente, do programa narrativo do sujeito 'performante' em relação ao sistema axiológico (de justiça, de 'boas maneiras', de estética etc.), implícito ou explícito, pelo menos tal como foi atualizado no contrato inicial. (GREIMAS \& COURTÉS, 2008, p. 426).

Dentro do modelo de thread que estamos analisando nesta pesquisa, numa sequência de textos e metatextos, o contrato proposto pelo enunciador inicial é unilateral, pois não se identifica 
claramente os valores do enunciatário. Tal situação propicia dificuldades no estabelecimento de uma sanção pragmática do discurso em fórum.

Porém, a ambiguidade do humor e do riso no espaço de fórum não é a única particularidade que dificulta a sanção dentro do espaço de fórum. Como observado nos capítulos anteriores, a ação dos fãs e o fandom como um todo é muito influente no espaço de fóruns.

\subsubsection{O fandom e a ambiguidade}

Henry Jenkins, em seu livro Textual Poachers: television, fans and Participatory culture (1992), já vislumbrava a ambiguidade interpretativa e, sua consequência disputa de axiologias, como parte da cultura do fandom. Mesmo numa análise geral do fenômeno do fandom, o autor afirma que:

Não há nada eterno e imutável sobre esta cultura, o fandom se origina em resposta a condições histórias específicas (não apenas configurações da grade televisiva, mas também o desenvolvimento do feminismo, novas tecnologias, a atomização e alienação da cultura contemporânea americana etc.) e se mantém em constante fluxo. (JENKINS, 1992, p. 3 - tradução nossa).

O autor ainda postula que, dentro do corpo social, este fandom é, além de mutável, sempre posto numa condição de "marginalidade". Jenkins argumenta que, baseado em valores estéticos e do bom-gosto, descritos pela sociologia como os valores de uma classe dominante e socialmente aceitos, o domínio do fã ${ }^{159}$ é o do gosto e da valoração de objetos que, dentro do resto da sociedade, não possuem tal valor. Ainda segundo Jenkins, o "mau-gosto" apresentado pelos fãs é punido pela sociedade. A respeito desta divergência entre a cultura do bom-gosto e a cultura dos fãs:

A cultura dos fãs mistura estas divisões, tratando textos populares como se estes merecessem o mesmo grau de atenção e apreciação de textos canônicos. Práticas de leitura (escrutínio, exegeses elaboradas, repetição e leitura prolongada etc.) aceitáveis quando usadas num trabalho de "mérito sério" parecem perversamente mal aplicados nos "dispensáveis" textos de cultura de massa. Fãs falam de

\footnotetext{
159 Tanto Henry Jenkins quanto Anne Jamison afirmam que a palavra fã (fan) é derivada da palavra fanático (fanatic),
} definida por Jamison como "um comportamento excessivo, próximo da loucura" (JAMISON, 2017, p. 163). 
"artistas" onde os demais só veem trabalhos comerciais, ou de significados transcendentes onde outros veem apenas banalidades, de "qualidade e inovação" onde outros veem apenas fórmulas e convenções. (JENKINS, 1992, p. 17 tradução nossa).

A partir da limitação por parte de uma noção específica de estética e bom gosto, da qual os objetos do fandom não fazem parte, cria-se uma desigualdade argumentativa entre fãs e seus críticos. Aos representantes da estética culta e socialmente estabelecida, cabiam críticas aos fãs (especialmente nos anos 90, objeto de observação do livro de Jenkins) como vítimas da cultura de massa, alienados, pervertidos, homens infantis e emasculados, mulheres histéricas e irresponsáveis. Da posição disfórica da estética, aos fãs não havia argumentos de igual intensidade.

A partir de tal desigualdade argumentativa, estratégias são desenvolvidas pelos fãs para o enfraquecimento de tal axiologia de valores, sendo a principal delas o apontamento de que tais comportamentos criticáveis partiriam de "outros" fãs ${ }^{160}$. "Para muitos, a única defesa legítima era alegar a 'normalidade' de seu estilo, professando sua conformidade geral com os valores da classe média como forma de criar um meio-termo com seus amigos não-fãs" (JENKINS, 1992, p. 20-21 - tradução nossa).

À medida que o fandom começa a se organizar na internet e nas redes sociais, entre o final dos anos 90 e o começo dos anos 2000, esta mudança exacerba a estratégia de segregação entre fãs de um mesmo fandom. "Ainda que tais conflitos não fossem novos [...] com a internet, no entanto, tornou-se possível que comunidades com gostos mais específicos se estabelecessem com mais facilidade e velocidade." (JAMISON, 2017, p. 127).

Como observado no item 2.6.3, os textos fantásticos são sempre usados como alegorias para o mundo real, e esta divisão e consequente disputa entre grupos de um mesmo fandom cria fenômenos como as guerras de shippers, quando grupos de fãs que torcem para casais de

\footnotetext{
${ }^{160}$ Não é porque os fãs fazem parte do fandom, que eles não acreditam, ainda que parcialmente, nos valores de bomgosto dominante. $\mathrm{O}$ equilíbrio entre estes dois conjuntos valores às vezes discrepantes é uma das atividades cotidianas que todo fã deve lidar.
} 
personagens $\left(\operatorname{ships}^{161}\right)$ diferentes se enfrentam numa espécie de discussão sobre a "validade" de cada um dos ships:

Guerras de shippers - que por muito tempo pareceram incompreensíveis para mim, porque não entendia como as pessoas poderiam ficar tão bravas com outras pessoas por elas gostarem de ler sobre as vidas sexuais de diferentes pessoas imaginárias - funcionam da mesma maneira. Para muitos fãs, quem você shippa, e como conta essa história, representa que tipo de relacionamento que você acha que é certo, o que se encaixa. Em toda esta dinâmica do fandom, a questão central pode ser a mesma: Quem pode contar a história? e de quem é a história? (JAMISON, 2017, p. 162)

Esta disputa sobre “quem pode contar a história? E de quem é a história?”, dentro do contexto da ambiguidade que está sendo aqui analisado, se apresenta sob a definição de fãs como Poachers (caçadores predatórios - em analogia à atividade ilegal de caçar elefantes e rinocerontes por suas presas e chifres, que em inglês é chamada de poaching).

Quando fala de "caça predatória”, Jenkins retoma as ideias de Michel de Certeau no livro A Invenção do Cotidiano (1998). Para este autor, o processo de leitura (definida como parte fundamental do processo de consumo) é erroneamente tratado em alguns estudos e teorias como um processo passivo. Tal pensamento, que incentiva consumidores e produtores técnicos a verem a si mesmos como "vítimas" das circunstâncias, igualmente reforça a ideologia das classes dominantes como detentoras da capacidade de doutrinar as classes menos dominantes.

O historiador francês busca ainda incentivar uma interpretação do ato de leitura em que “esta transformação se efetuou sob a figura de uma 'mestiçagem' entre dois elementos distintos, o escrito e o oral." (DE CERTEAU, 1998, p. 263). Esta mesclagem entre fala e escrita é defendida por Pessoa de Barros (2015b) como um elemento definidor da complexidade discursiva da internet.

Outro elemento proposto por De Certeau, que encontra ecos no referencial teórico desta pesquisa está na construção do sentido do texto. O autor alinha-se com outros que defendem o processo de leitura como o processo de construção de um novo texto, e não uma co-criação ou interpretação do texto existente, afirmando que "Se portanto o 'livro é um efeito de construção do

161 Ships são o termo que designa qualquer relação marcante entre dois (ou mais) personagens de um universo ficcional. Descrito em detalhes no glossário ao fim da dissertação. 
leitor' [...] este [o leitor] não toma nem o lugar do autor, nem um lugar do autor. Inventa nos textos outra coisa que não aquilo que era a 'intenção' deles [os tradicionais papéis de autor]. Destaca-os de sua origem e cria algo não-sabido" (DE CERTEAU, 1998, p. 265).

Tal criação discursiva durante o ato de leitura vai ao encontro às concepções já aqui abordadas de Espen Aarseth (1997), que chama de Ergódica a esta definição de leitura proposta por De Certeau. Ainda que o foco do autor sejam os textos digitais, este afirma que os princípios de leitura ergódica sempre estiveram presentes na sociedade, pois "O livro é adequando para o discurso linear mas é igualmente adequado para discursos não-lineares, como uma enciclopédia ou livros do tipo "escolha sua aventura"” (AARSETH, 1997, p. 46 - tradução nossa).

Os autores também atribuem à linearidade e interpretações tradicionais um caráter de coerção social: Aarseth vê a tradição da linearidade atribuída a escolhas ideológicas dos pesquisadores, enquanto De Certeau vê o "sentido oficial" como algo que pode ser produzido apenas por indivíduos autorizados pela cultura dominante, e que de alguma forma corrobora ideais da cultura dominante ${ }^{162}$.

Diante destes princípios teóricos, De Certeau afirma que:

Longe de serem escritores, fundadores de um lugar próprio, herdeiros dos servos da linguagem de antigamente mas agora trabalhando no solo da linguagem, cavadores e construtores de casas, os leitores são viajantes; circulam nas terras alheias, nômades caçando por conta própria através dos campos que não escreveram, arrebatando os bens do Egito para usufruí-los. A escritura acumula, estoca, resiste ao tempo pelo estabelecimento de um lugar e multiplica sua produção pelo expansionismo da reprodução. (DE CERTEAU, 1998, p. 269-270).

A partir da proposta de De Certeau, Jenkins propõe que o Poaching praticado pelos fãs contemporâneos é uma característica marcante destes, bem como atividade fundamental de seu estatuto:

O que é significativo sobre os fãs em relação ao modelo de Certeau é que eles constituem uma comunidade particularmente ativa e vocal de consumidores cujas atividades atraem atenção para este processo de apropriação cultural. Assim, eles

162 As ideias de De Certeau sobre o jogos de poder dentro da escrita e consumo vão num caminho similar às interpretações de Canclini (2007) sobre a globalização da cultura, abordadas em destaque neste trabalho no item 2.6.3. 
possuem um status contemporâneo parecido com os membros do 'fosso' no teatro do século 19 que mostravam sua autoridade sobre a performance, parecido com os leitores de Dickens e outros escritores de crônicas que escreviam suas próprias sugestões para desenvolvimentos de enredo [...] Fãs não são únicos em seu status como Poachers textuais, mas, eles desenvolveram o poaching como uma forma de arte. (JENKINS, 1992, p. 28 - tradução nossa).

A manipulação dos elementos do discurso de maneira seletiva por parte dos fãs será exemplificada a seguir, porém antes é necessário lembrar de um último elemento que possui relevância na construção da ambiguidade discursiva característica do discurso de fóruns.

\subsubsection{A ambiguidade da leitura ergódica}

O assunto da leitura ergódica já foi abordado anteriormente nesta pesquisa, principalmente no item 2.4. No presente item cabe apenas observar que a variedade de hipertextos disponíveis para os visitantes do fórum durante seu processo de leitura ocasiona uma tendência a interpretações divergentes de um mesmo texto.

Num artigo de 2017, intitulado "Contar e participar: Análise da tradução intersemiótica do videogame assassin's creed II para romance", Renata Mancini e Paulo Souza Júnior utilizam os conceitos de leitura ergódica e cybertexto propostos por Aarseth para analisar modalidades participativas em textos literários. Os autores afirmam que:

Para o nosso trabalho, o importante é observar como os enunciadores dessas obras, ao preverem variados caminhos de leitura possíveis, projetam um efeito de interação no discurso, e que essa é uma estratégia que imprime subjetividade às obras - tornando sua apreciação uma experiência mais íntima e peculiar (MANCINI \& SOUZA JÚNIOR, 2017, p. 37-38).

A própria dinâmica proposta pela leitura ergódica permite, de acordo com o artigo de Mancini e Souza Júnior e também desta presente pesquisa, um maior efeito de subjetividade. Quando o referencial de cada membro da comunidade difere, em função do percurso feito por estes entre os hiperlinks que contém os trechos da narrativa, mesmo fatos abordados de forma objetiva acabam por ter um efeito de subjetividade reforçados. "Sob o ponto de vista das estratégias enunciativas [...] o leitor é convidado a participar, interagir, moldar seu percurso (MANCINI \& SOUZA JÚNIOR, 2017, p. 39). 
Uma última observação se faz necessária: Mancini \& Souza Júnior baseiam suas observações em obras que, geralmente, são de autoria de um único produtor, e onde a navegação entre diversos hiperlinks gera apenas o efeito ou simulacro de ação do leitor na construção da narrativa, pois todos os caminhos possíveis da narrativa são, em alguma medida, previstos pelo produtor do discurso. No caso dos fóruns analisados por esta pesquisa, eles se aproximam mais das análises de Aarseth (1997) sobre MUDs (Multi-User Dungeons), em que os hiperlinks por onde um enunciatário percorre são providos por diversos produtores. Há, portanto, uma real agência do enunciatário na construção do discurso lido, já que nenhum dos produtores envolvidos nos fóruns possui um controle efetivo dos hiperlinks que compõe tais textos.

Expostos três elementos que operam numa cristalização da ambiguidade nos espaços de fórum (dinâmicas humorísticas, princípios constituintes dos fóruns e o texto ergódico), esta pesquisa agora apresentará alguns exemplos de como tais elementos alteram as veridicções dentro do espaço de fórum.

\subsubsection{O discurso de autoridade e a conspiração}

Em 7 de Janeiro de 2019 ${ }^{163}$, a Blizzard lançou o quadrinho Bastet ${ }^{164}$, que continha um aprofundamento da narrativa da personagem Ana Amari, que à época estava sendo lançada no jogo. Neste quadrinho, numa conversa entre a personagem Ana Amari e o personagem Jack Morrison, o Soldado 76, é revelado que este possuía um relacionamento amoroso com outro homem no passado.

Posteriormente, no mesmo dia, o escritor-chefe do jogo na época, Michael Chu, fez um post em sua conta na rede social Twitter, confirmando a canonicidade da orientação sexual da personagem Soldado 76.

${ }^{163}$ STRAPAGIEL, Lauren. "Overwatch” Hero Soldier: 76 Is Gay And The Reactions Are Just The Best. BuzzFeed News. 08 jan. 2019. Disponível em: <https://www.buzzfeednews.com/article/laurenstrapagiel/soldier-76-fromOverwatch-has-been-confirmed-as-gay-and>. Acesso em: 04 jan. 2021.

${ }^{164}$ OVERWATCH WIKI. Bastet. Fandom. Disponível em: 〈https://Overwatch.gamepedia.com/Bastet>. Acesso em: 04 jan. 2021. 
Figura 61 - Postagem no twitter de Michael Chu.
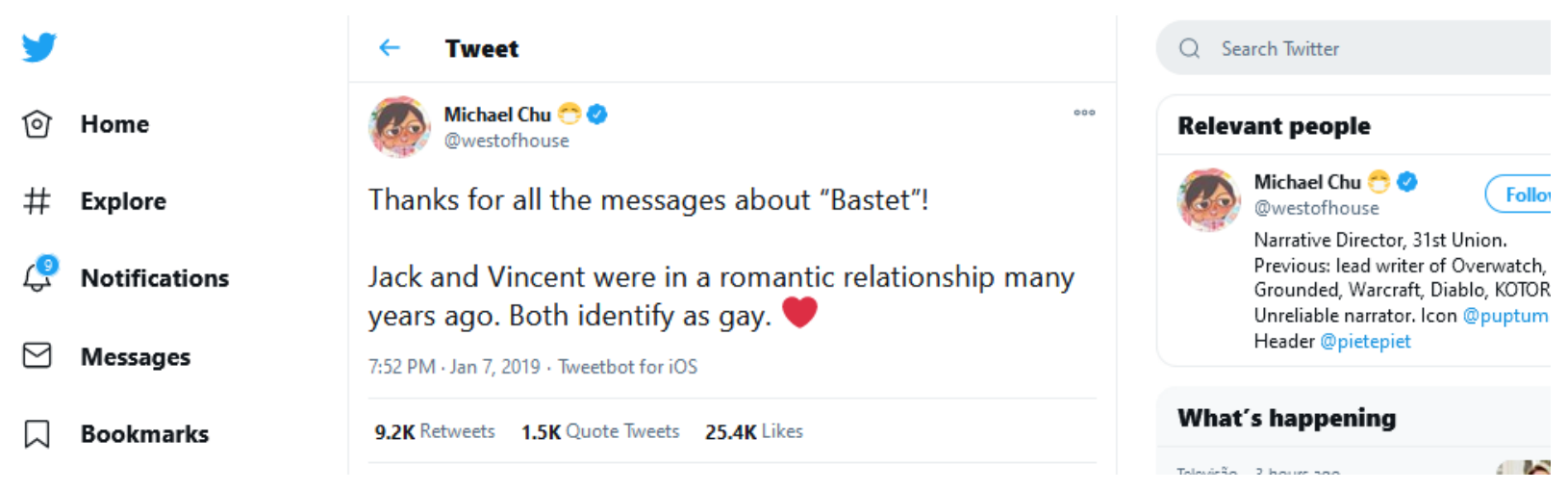

Fonte: Twitter $(2021)^{165}$.

A tradução do comentário acima seria “Obrigado por todas as mensagens sobre 'Bastet'! Jack e Vincent estiveram em um relacionamento romântico muitos anos atrás. Ambos se identificam como gay". As reações da comunidade a esta revelação, como comprova o observado no item 2.5.3 desta pesquisa, foram mistas, com elogios e críticas a este desenvolvimento narrativo para o personagem. Observaremos agora as estratégias discursivas utilizadas pelos críticos contrários a tal desenvolvimento, do ponto de vista da veridicção.

No Dicionário de Semiótica, uma das características que definem a sanção como “exercida pelo Destinador final, pressupõe nele um absoluto de competência” (GREIMAS \& COURTÉS, 2008, p. 426). No livro Teoria do Discurso: Fundamentos Semióticos, Diana Pessoa de Barros fala sobre o argumento de autoridade, destacando também o caráter de influência e poder na sanção do destinador final:

$\mathrm{O}$ argumento de autoridade, formulado em termos actanciais na sintaxe narrativa, deve ser considerado como a convocação de auxiliares do sujeito ou do antisujeito - adjuvantes ou oponentes - para que cumpram programas narrativos de uso: atribuam competência ao sujeito ou realizem, em seu lugar, fazeres necessários ao programa de base (BARROS, 1988, p. 111).

Outro autor a abordar o conceito do discurso de autoridade, Oswald Ducrot (1987) diferencia o discurso de autoridade, do ponto de vista sintáxico, em dois tipos: O chamado

165 Disponível em: <https://twitter.com/westofhouse/status/1082394625837428736>. Acesso em: 10 mar. 2021. 
Arrazoado por autoridade, em que se apresenta uma informação como uma asserção de um locutor, e em seguida se faz uma nova asserção da asserção. O outro tipo descrito por Ducrot é a Autoridade Polifônica, onde, no ato de uma enunciação, confundem-se o locutor da frase e o locutor da referência de autoridade feita.

Em função desta ambiguidade, o autor admite que "é habitual, em um discurso, tirar de talvez X as mesmas conclusões que seriam justificadas somente se se admitisse a verdade de X." (DUCROT, 1987, p. 146), portanto, a concordância com uma asserção intuída pelo próprio enunciador possui a tendência a ser encarada como uma asserção de fato. Na postagem acima, do perfil Michael Chu, vemos também um exemplo de Autoridade Polifônica, onde Michael Chu se refere a uma enunciação de Soldado 76 e seu ex-noivo Vincent (se identificam como), mas que é, na verdade, uma enunciação do próprio perfil Michael Chu.

Nos fóruns, existe a iniciativa de que se use o argumento de autoridade, como no exemplo abaixo, retirado de uma das respostas à postagem de Michael Chu:

Figura 62 - Resposta no Twitter à postagem de Michael Chu.
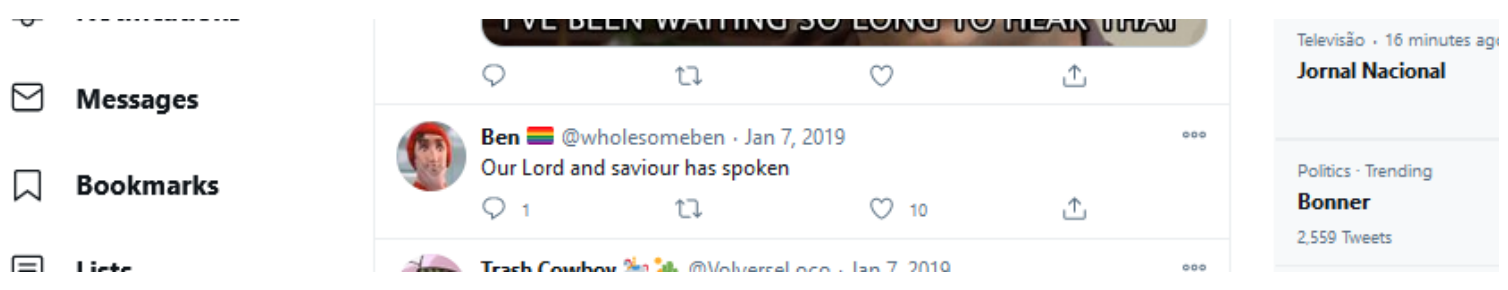

Fonte: Twitter $(2021)^{166}$.

Na imagem acima, o usuário Ben diz "Nosso senhor e salvador falou”. Este comentário usa figuras da "palavra de Deus" do escritor-chefe de Overwatch como uma espécie de palavra final, um argumento de autoridade. Este é um exemplo do Arrazoado por Autoridade, em que o perfil Ben faz uma asserção sobre a asserção do perfil Michael Chu. Neste caso, a implicação entre as duas frases vem do fato do comentário ser uma frase subjugada, dentro das mecânicas do fórum, ao comentário do perfil de Michael Chu.

166 Disponível em: <https://twitter.com/westofhouse/status/1082394625837428736>. Acesso em: 10 mar. 2021. 
Porém ambas as estratégias possuem sua eficácia reduzida dentro dos espaços de fórum analisados, e um dos motivos é a própria constituição do fórum, analisada no capítulo 3 desta pesquisa. Mesmo que Michael Chu fosse à época o escritor-chefe de Overwatch, seu anúncio veio através de um post no Twitter, meio disponível por seus detratores ou apoiadores. Nos espaços de fórum analisados ${ }^{167} 168$, os termos de acordo que regem tais interações e apresentam suas punições costumam versar principalmente sobre ameaças de bullying ou violência, discursos de ódio, divulgação de conteúdo pornográfico ou infrações similares. E ainda sim, há críticas sobre certa leniência ${ }^{169}$ com tais tipos de conteúdo ${ }^{170}$.

Porém, não existe nenhum tipo de punição ou sanção que o destinador julgador possa dar a quem questione ou publique discursos que divirjam do texto canônico do universo fantasioso do videogame. As ferramentas disponíveis nos fóruns analisados deixam o poder da manipulação do destinador enfraquecido, portanto pouco eficaz em criar as condições de veridicção necessárias para o convencimento dos enunciatários.

Nesta linha, Jenkins (2009) observa em seus estudos que esforços feitos por autores e produtores para controlar a liberdade de seus fandons (nominalmente, George Lucas sobre Star Wars e J.K. Rowling sobre Harry Potter) através de processos e expulsão de fóruns.

Tais esforços acabaram caído por terra, pois "Cada vez mais, entretanto, a web tem se tornado um local de participação do consumidor, que inclui muitas maneiras não autorizadas e não previstas de relação com o conteúdo de mídia” (JENKINS, 2009, p. 190). Como exemplo, diversas imagens mostrando o personagem Soldado 76 em relações românticas/sexuais com outras

${ }^{167}$ REDDIT. Reddit Content Policy. Reddit. Disponível em: <https://www.redditinc.com/policies/content-policy>. Acesso em: 06 jan. 2021.

168 YOUTUBE. Diretrizes da Comunidade. Youtube. Disponível em: <https://www.youtube.com/howyoutubeworks/ policies/community-guidelines/>. Acesso em: 06 jan. 2021.

${ }^{169}$ LEWIS, Becca. I warned in 2018 YouTube was fueling fariright extremismo. Here's what the platform should be doing. The Guardian. 11 dec. 2020. Disponível em: <https://www.theguardian.com/technology/2020/dec/ 11/youtube-islamophobia-christchurch-shooter-hate-speech>. Acesso em: 06 jan. 2021.

${ }^{170}$ ANONYMOUS. I Became part of the alt-right at age 13, thanks to Reddit and Google. Fast Company. 12 mai. 2019. Disponível em: <https://www.fastcompany.com/90438818/i-became-part-of-the-alt-right-at-age-13-thanks-toreddit-and-google>. Acesso em: 06 jan. 2021. 
personagens femininas foram postadas no fórum de imagens Dambooru ${ }^{171}$, mesmo após a postagem de Michael Chu.

Outra estratégia importante de ser observada está na argumentação, especialmente no uso do argumento de autoridade citado mais acima a partir de Pessoa de Barros (1988). Ainda referente aos movimentos discursivos relativos ao anúncio de Michael Chu sobre a sexualidade da personagem Soldado 76, esta pesquisa apresenta logo abaixo a imagem de uma argumentação retirada do Fórum de imagens Dambooru, onde um perfil critica esta revelação:

Figura 63 - Comentários em postagem do site Dambooru.

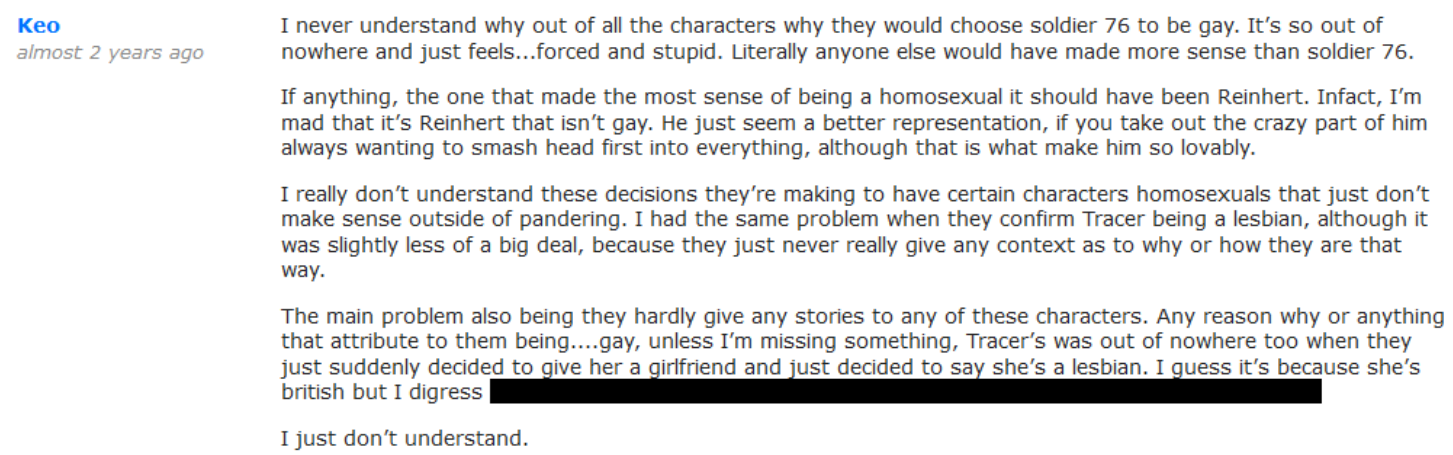

Fonte: Danbooru $(2021)^{172}$.

Na nossa tradução, o comentário do usuário Keo é o seguinte:

Eu nunca entendi por que, de todos os personagens, eles iriam escolher o Soldado 76 para ser gay. É tão sem sentido e parece... forçado e estúpido. Literalmente qualquer outro teria feito mais sentido do que o soldado 76.

Inclusive, alguém que faria muito sentido em ser gay seria o Reinhart. Aliás, eu estou bravo que não é o Reinhart que é gay. Ele parece um melhor representante, se você tirar a parte louca de ele sempre querer ser o primeiro a partir pra cima de tudo, apesar de que é isso que faz ele ser tão adorável.

Eu não entendo essas decisões que eles fazem sobre certos personagens serem homossexuais, que não faz nenhum sentido além de ser condescendência. Eu tive

${ }^{171}$ MARMALADE MUM. Post de Imagem. Danbooru. Disponível em: <https://danbooru.donmai.us/posts/3386736>. Acesso em: 07 jan. 2021.

172 Disponível em: <https://danbooru.donmai.us/posts/3386736>. Acesso em: 10 mar. 2021. 
o mesmo problema quando eles confirmaram a Tracer como sendo lésbica, apesar de que isso foi menos importante, por que eles nunca deram qualquer contexto do porquê ou como ela era desse jeito.

O principal problema é que eles não dão qualquer história para esses personagens. Nenhuma razão ou motivo para eles serem... gays, a não ser que eu tenha perdido algo. Sobre a Tracer, aquilo veio de lugar nenhum, quando eles simplesmente decidiram dar uma namorada pra ela e dizer que ela era lésbica. Acho que é por que ela é inglesa, mas estou divagando aqui.

Este comentário recebeu duas respostas de outros usuários:

Figura 64 - Comentários em postagem do site Danbooru.

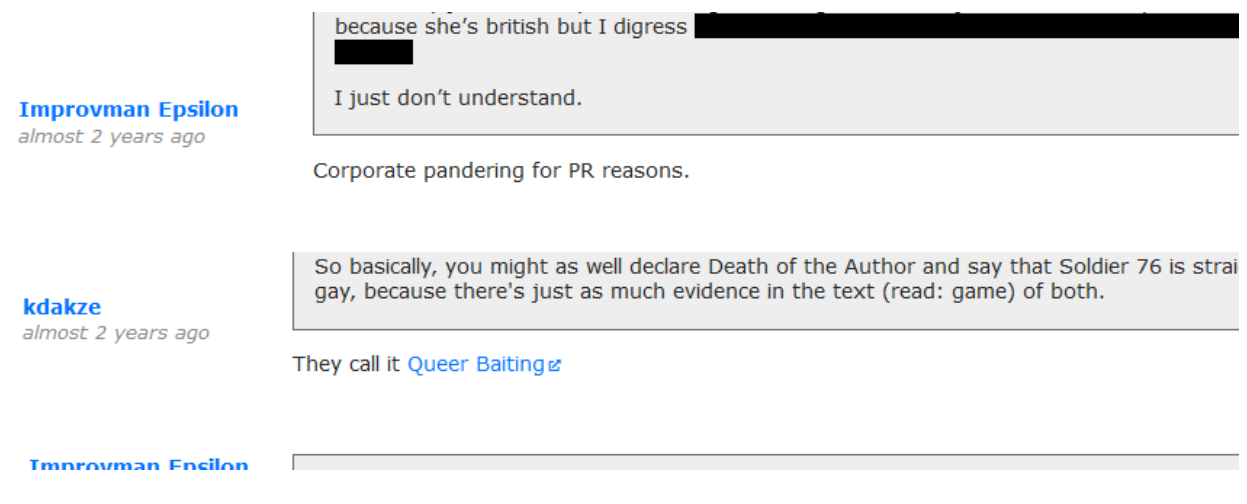

Fonte: Danbooru $(2021)^{173}$.

O perfil Improvman Epsilon diz "Condescendência corporativa por razões de relações públicas”, enquanto o perfil kdakze diz "Eles chamam isso de Queer Baiting ${ }^{174 ” . ~}$

Nos comentários analisados, os três perfis utilizam uma estratégia similar: descredibilizar a autoridade do perfil enunciador. Ainda que o perfil se apresente como Michael Chu, escritorchefe de Overwatch, portanto um argumento de autoridade, Improvman Epsilon e kdakze afirmam que, na verdade, Michael Chu está cumprindo um programa, manipulado por outro destinador, no

173 Disponível em: <https://danbooru.donmai.us/posts/3386736>. Acesso em: 10 mar. 2021.

${ }^{174}$ Queer Baiting é um termo que circula na internet, mas de estatuto duvidoso, usado para definir uma estratégia de marketing que se utiliza da sugestão de relacionamentos homoafetivos entre personagens (que, porém, nunca são confirmados) com o objetivo de atrair a audiência LGBTQIA+. Tal estratégia seria baseada na popularidade de trabalhos do fandom que apresentam relacionamentos homoafetivos (chamados de slash) e estudados por Jamison (2017). 
caso o departamento de Marketing da Blizzard, desenvolvedora de Overwatch (ou, num segundo momento, a comunidade LGBTQIA+.

Ao afirmar que, cumprindo um programa de Base proposto pelo destinador-julgador (Marketing da Blizzard), o sujeito (Michael Chu) está sendo recompensado positivamente (Mais dinheiro e popularidade para a Blizzard), e axiologizando negativamente tal programa de base (já que, segundo os perfis, o escritor-chefe deveria se preocupar em escrever "boas histórias", e não em agradar demográficos específicos) os perfis Improvman Episilon, Keo e kdakze diminuem a autoridade do enunciador Michael Chu, transferindo a origem da modalização do enunciador para uma entidade amorfa (neste caso, o Departamento de Relações Públicas da Blizzard), enquanto simultaneamente propõe a interpretação de seu discurso sob outra axiologia, para sancioná-lo negativamente.

Aqui temos outros exemplos de críticas, retiradas da thread do anúncio da orientação sexual do Soldado 76, feito por Michael Chu no Twitter:

Figura 65 - Resposta no Twitter à postagem de Michael Chu.

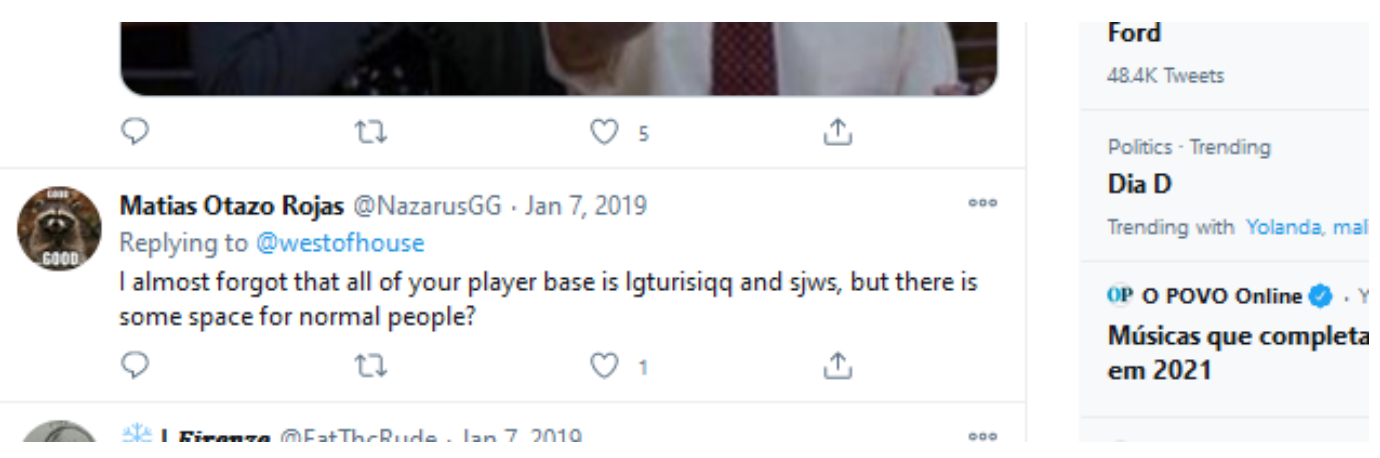




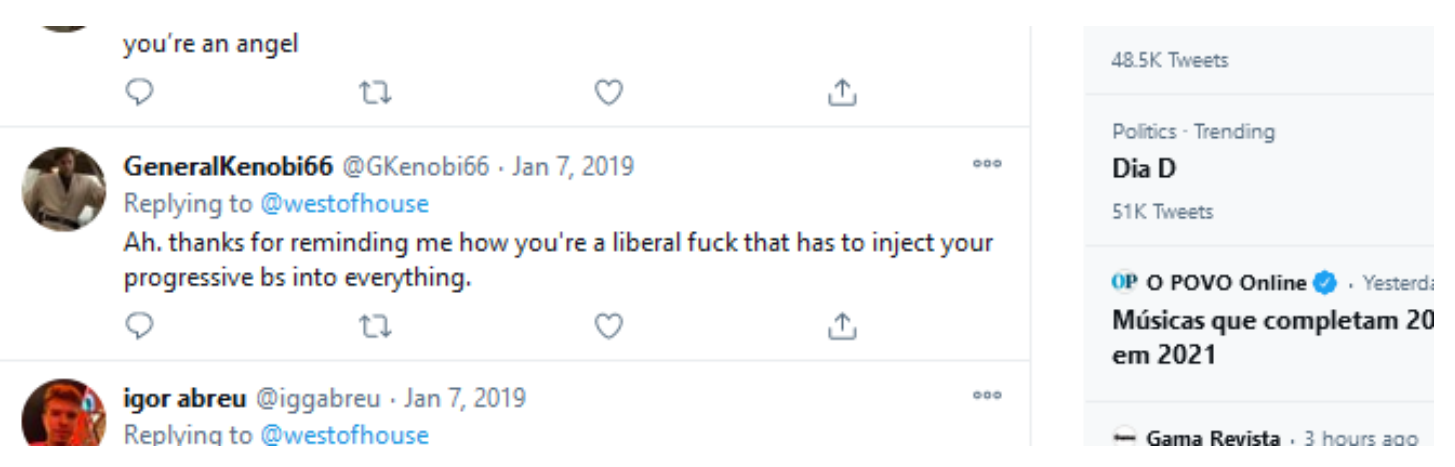

Fonte: Twitter $(2021)^{175}$.

O perfil Matias Otazo Rojas diz que "Eu quase esqueci que toda a sua base de jogadores são LGBTzxoanjdksr e SJWs, mas irá haver algum espaço para as pessoas normais?”. Já o perfil GeneralKenobi66 disse "Ah, obrigado por me lembrar como você é um escroto liberal que tem que injetar sua merda progressiva em tudo".

Todos os perfis críticos à decisão narrativa anunciada pelo perfil enunciador Michael Chu possuem o mesmo tipo de estratégia: reenquadrar o discurso do enunciador como um programa de uso, manipulado por um destinador, que nos exemplos acima recebeu diversos nomes: Departamento de Marketing da Blizzard, SJWs (Social Justice Warriors, como são apelidadas as pessoas que vigiam a implementação e manutenção de pautas progressistas na sociedade), Progressistas etc. No Brasil este tipo de papel costuma ser atribuído à Ditadura Gayzista ou Lacradores por exemplo ${ }^{176}$.

Todos estes enunciadores, apesar dos recobrimentos figurativos diferentes, possuem duas características recorrentes. A primeira delas é um recobrimento figurativo de conspiração: são apresentados como grupos seletos, que se ocultam em núcleos e fóruns fora dos fóruns de jogos, que agem de maneira manipuladora e com objetivos a longo prazo.

175 Disponível em: <https://twitter.com/westofhouse/status/1082394625837428736>. Acesso em: 10 mar. 2021.

176 DUBLANDO COISAS. Soldado 76 Virou Gay! Youtube. Disponível em: <https://www.youtube.com/watch?v= NX3IYkEfmT4>. Acesso em: 11 jan. 2021. 


\subsubsection{O destinador transcendente e a conspiração}

Quando se lê, dentro dos textos-contextos que circulam no fórum, as ações e capacidade atribuídas a estes enunciadores, percebe-se estar diante de um exemplo de um destinador transcendente. Este tipo de destinador foi abordado em detalhes pelo semioticista Luiz Tatit em seu livro Semiótica à luz de Guimarães Rosa, onde o autor paulista analisa o uso do destinador transcendente na obra do autor mineiro intitulada Nada e a nossa condição. Tatit descreve:

O destinador transcendente possui um estatuto especial. Representa uma função transitiva responsável pelo projeto maior do sujeito: sua constante busca de junção. Esse destinador articula disjunção e conjunção como estágios de um mesmo processo que mantém o sujeito em continuidade. Propõe logo a sutura em lugar da fratura. Difere portanto - já que pertence a um nível mais profundo - do manipulador e do julgador (embora possa eventualmente manifestar-se como tais), que constituem, respectivamente, etapas inicial e final do percurso narrativo. O destinador transcendente paira sobre todas as operações executadas e as paixões vividas pelo sujeito ao longo de sua trajetória. Ele acolhe as interrupções como elementos indispensáveis à continuidade. É por seu intermédio, pela força transitiva de sua atuação, que as narrativas não param. (TATIT, 2010, p. 20).

No caso dos fóruns analisados, especificamente, este destinador transcendente costuma ser invocado para representar um programa disfórico (no exemplo abordado, os destinadores Departamento de Marketing, SJW e Lacração manipulam seus sujeitos num eixo de homossexualidade [eufórico] e Heterossexualidade [disfórico], que são valores opostos aos discursos dos perfis GeneralKenobi66, Improvman Epsilon e Matías Otazo Rojas. Nos fóruns analisados, portanto, a estratégia mais comum é a invocação de um anti-destinador transcendente.

Entre as outras características do destinador transcendente descrito por Tatit, está uma espécie de inesgotabilidade de bens para manipulação, em que o dito destinador está sempre em condição de possuir o saber e o poder de manipular os sujeitos. Outra característica é a ocultação de suas ações: a ocultação do plano do destinador para com o sujeito. $\mathrm{O}$ destinador transcendente intervém na jornada do sujeito do começo ao fim, não apenas no início (destinador-manipulador) ou apenas no final (destinador-julgador), e em função disso, apenas este destinador transcendente "possui consciência de todo o processo vital" (TATIT, 2010, p. 24).

Este destinador transcendente possui uma certa estabilização dentro dos discursos religiosos (por exemplo, Deus ou o Espírito Santo). Porém no caso do corpus analisado, este destinador 
transcendente, poderoso que manipula seus sujeitos para além de seu conhecimento, acaba por reforçar a estratégia de retirar o poder de sanção dos enunciadores que discursam em fórum, independentemente do tipo de estratégia sintáxica usada. Bem como, auxilia na figurativização da conspiração, que os críticos pretendem usar de maneira disfórica na construção de seus alvos.

\subsection{5 - Os pressupostos e a interrupção da discussão}

Outra estratégia que surge dentro dos fóruns, também em resposta a tentativas de sanção, é o uso de pressupostos. Objeto de estudo de Ducrot (1987) e Pessoa de Barros (1988), a utilização dos pressupostos em um enunciado são as "indicações que ele traz, mas a partir das quais o enunciador não quer (quer dizer, faz como se não quisesse) fazer recair o encadeamento. Trata-se de indicações que se dão, mas que se dão à margem da linha argumentativa do discurso (DUCROT, 1987, p. 38). Ainda segundo o autor, o que explica a função por trás do pressuposto é:

Consideram-se pressupostos, em um enunciado, o que é trazido pelo enunciado, mas não de forma argumentativa, entendendo por isso que não se apresenta como devendo orientar a continuação do discurso. [...] Dizendo Você está quase atrasado, pressuponho que você não esteja atrasado: isso significa que o reconheço, mas a continuação que proponho a nosso discurso não diz respeito ao fato de que você não está atrasado; diz respeito ao fato de que você estava na iminência de atrasar-se. (DUCROT, 1987, p. 39)

Pessoa de Barros descreve como esta estratégia pode ser usada para "prender" o enunciatário dentro de um conjunto de valores conveniente ao enunciador, através de um emprego retórico:

O enunciador pode colocar como conteúdo pressuposto, por definição constituído de crenças e conhecimentos presumidos comuns ao enunciador e ao enunciatário, certas informações que ele sabe não serem compartilhadas com o enunciatário. Evita dizê-las diretamente, para não caracterizar intrusão, indiscrição ou mesmo injúria, mas as faz passar de qualquer forma. (BARROS, 1988, p. 101).

A eficácia deste tipo de estratégia discursiva, reside no fato de que negar tais pressupostos acaba por ser contraproducente, e inviabilizam a própria continuidade da conversa: por um lado, negar tais pressupostos impede que a conversa prossiga, pois desviaria o foco do ponto principal do discurso para o que deveria ser ponto pacífico. Do outro, caso tente-se atacar a estratégia do 
enunciador, "O locutor não pode ser atacado por isso, já que o diálogo posterior não deve referirse a ela" (DUCROT, 1987, p. 42). O enunciador sempre poderá se esquivar da responsabilidade de um pressuposto, pois este não reside no discurso de tal enunciador.

A seguir, temos um exemplo retirado de nosso corpus, ainda a respeito dos desdobramentos do anúncio de Michael Chu sobre o Soldado 76. Em uma postagem no fórum oficial da Blizzard ${ }^{177}$, uma thread propunha a interpretação que o anúncio da sexualidade do personagem Soldado 76 foi usado para encobrir uma atualização que recebeu grandes críticas da comunidade. O caso também recebeu outras acusações, como os méritos narrativos deste anúncio e como ele foi manejado no quadrinho Bastet ${ }^{178}$. Na thread do fórum da Blizzard, o perfil DPapercut fez o seguinte comentário:

Figura 66 - Comentário numa thread do fórum da empresa Blizzard.

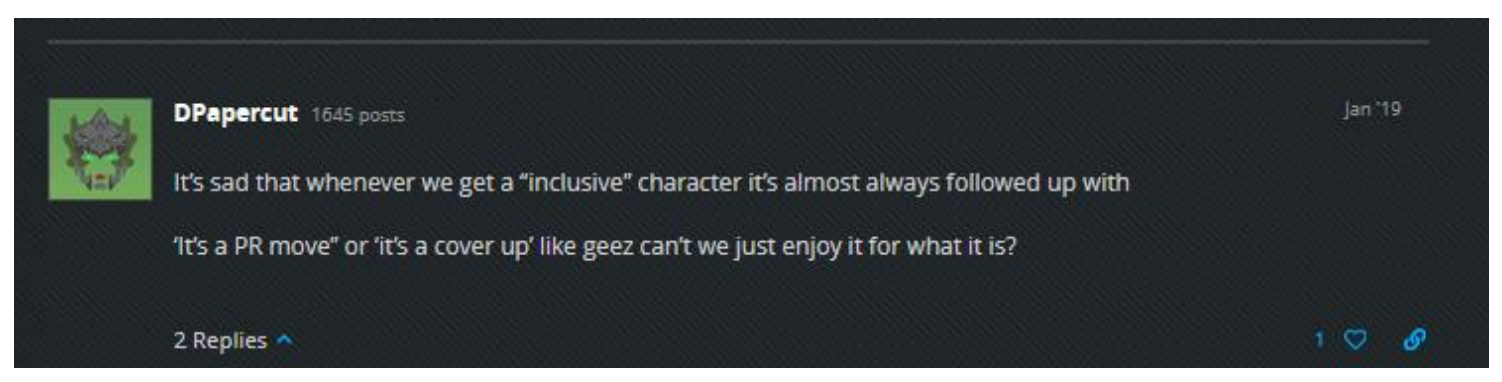

Fonte: Blizzard $(2021)^{179}$.

O comentário do perfil DPapercut se traduz como "É triste como toda a vez que ganhamos um personagem 'inclusivo', quase sempre ele é seguido por 'é uma jogada de marketing' ou 'é uma cortina de fumaça'. Tipo, pô, a gente não pode aproveitar isso pelo que ele é?"

177 BLIZZARD FÓRUNS. Blizzard used Soldier: 76 as a PR and marketing ploy. Blizzard. Disponível em: <https://us.forums.blizzard.com/en/Overwatch/t/blizzard-used-soldier-76-as-a-pr-and-marketing-ploy/281945>. Acesso em: 19 jan. 2021.

178 GOOSE BOOSE. My Main Issue With Soldier 76 Being Gay. Youtube. Disponível em: <https:// www.youtube.com/watch?v=yXndhMDT1k4>. Acesso em: 19 jan. 2021.

179 Disponível em: <https://us.forums.blizzard.com/en/overwatch/t/blizzard-used-soldier-76-as-a-pr-and-marketingploy/281945>. Acesso em 10 mar. 2021. 
É possível perceber que, enquanto a pergunta do perfil DPapercut seja sobre aproveitar ou não os efeitos do anúncio, fica subentendido que todos os críticos deste movimento, na verdade, possuem intuito homofóbico em suas críticas.

O resultado deste tipo de intervenção nos espaços de fórum analisados é, em certa medida, uma reversão da estratégia descrita por Pessoa de Barros: ao se utilizar de tais pressupostos, o objetivo do enunciador muitas vezes é que o enunciatário se dirija ao conteúdo pressuposto, e dessa forma interrompa suas ações veridictórias sobre o tópico da thread. No exemplo acima, o pressuposto lançado por DPapercut de que todas as críticas à revelação da orientação sexual do personagem Soldado 76 eram discursos homofóbicos, levou outros membros do fórum a, ao invés de falarem sobre o uso do anúncio como ferramenta de marketing (o argumento que originou a thread), se defenderem da acusação de Homofobia, como o perfil Alottagay, que comentou pouco depois:

Figura 67 - Comentário numa thread do fórum da empresa Blizzard.

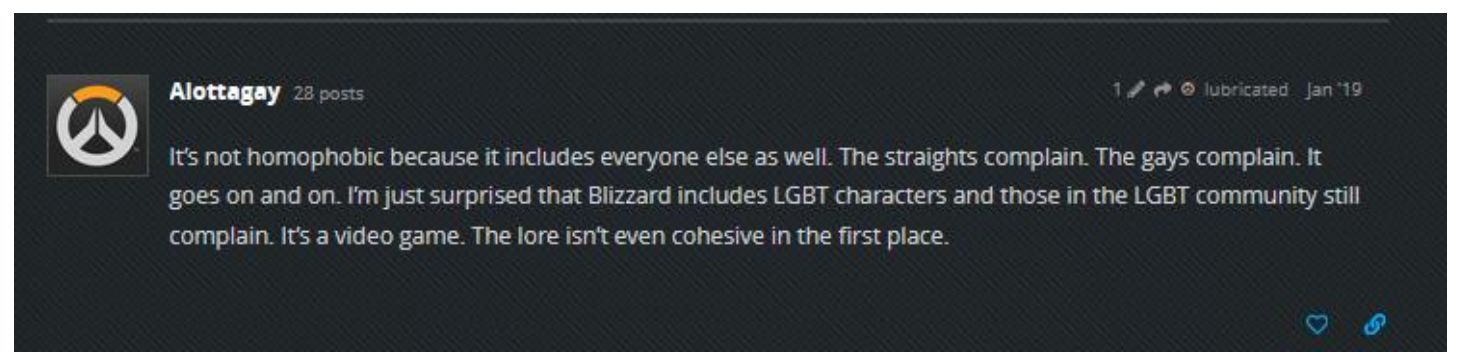

Fonte: Blizzard $(2021)^{180}$.

O comentário do perfil Alottagay se traduz por "Não é homofóbico porque inclui a todos também. Os héteros reclamam, os gays reclamam, e assim vai indo. Eu só estou surpreso que a Blizzard inclui personagens LGBT e os membros da comunidade LGBT ainda reclamam. É um videogame. O enredo não é sequer coeso para começar”. Esta estratégia de uso dos pressupostos como provocações para interromper um processo de discussão de veridicção de um discurso se

180 Disponível em: <https://us.forums.blizzard.com/en/overwatch/t/blizzard-used-soldier-76-as-a-pr-and-marketingploy/281945>. Acesso em: 10 mar. 2021. 
repete com grande frequência dentro dos fóruns analisados, valendo uma observação na presente pesquisa.

Uma última observação sobre os pressupostos deve ser feita: Ducrot, posteriormente à publicação de sua teoria sobre pressupostos e subentendidos em 1969, publicou uma espécie de reavaliação em 1978, onde comentou que era necessário rever a posição - que ele mesmo havia proposto - de que todos os sentidos identificáveis num pressuposto estariam previstos na própria significação da frase.

Tal retificação se prova adequada ao observarmos os pressupostos no nosso corpus. Pela ausência de hierarquia, bem como pela vinculação de comentários anteriores (uma prática que não é sempre realizada pelos perfis), é improvável que parte dos pressupostos pudesse ser compreendida se não pelo seu contexto com os outros comentários da thread.

\subsubsection{Os subentendidos e a responsabilidade}

Um último tipo de estratégia discursiva utilizado nos espaços de fórum analisados é o emprego de subentendidos. Esta estratégia discursiva consiste em:

Um efeito de sentido que surge na interpretação e que resulta do reconhecimento das razões do enunciador em dizer o que disse. Essa definição de subentendido indica que a pressuposição e demais atos ilocucionais apresentam-se no componente retórico sob a forma de subentendidos. (BARROS, 1988, p. 102.)

Este efeito de sentido, que em certa medida engloba o funcionamento dos pressupostos vistos anteriormente, é diretamente ligado ao momento da enunciação da mensagem, “...é construído como resposta à pergunta 'Por que ele falou desse modo?'. Em outras palavras, o locutor apresenta sua fala como um enigma que o destinatário deve resolver" (DUCROT, 1987, p. 42).

Outro indicativo da presença de subentendidos, e que também indica para a importância do momento da enunciação, é a adequação a duas leis do discurso, propostas por Ducrot: o da informatividade, que propõe que o enunciador deve falar algo que o enunciatário desconheça, exaustividade, que propõe que as informações devem ser sempre as mais fortes sobre o assunto, e a lítotes, que propõe que o enunciador leva o enunciatário a ver o enunciado como dizendo mais 
do que sua significação literal. A partir das regras de lílotes, exaustividade e informatividade, quando um enunciatário vê uma enunciação que parece inútil ou redundante, isto leva-o (e, em certa medida, incentiva-o) a buscar o subentendido no discurso.

E, assim como no caso dos pressupostos, os subentendidos também possuem uma mecânica estratégica:

O sentido, que é sempre, para mim, um retrato da enunciação, é então um retrato cuja responsabilidade o locutor deixa na mão do destinatário, processo quase explícito na expressão ‘eu não o obrigo a dizer' (o locutor parece aceitar, sem lhes dar origem, os subentendidos decifrados pelo destinatário). Perguntar-me-ão como é possível aceitar a interpretação do outro, a imagem que ele constrói do ato de enunciação, sem assumir a sua responsabilidade - o que é necessário para que se possa falar de sentido subentendido. Tudo o que posso dizer é que a linguagem oferece exemplos frequentes dessa atitude, certamente muito hipócrita. (DUCROT, 1987, p. 42).

Porém, dentro dos fóruns analisados por esta pesquisa, o uso do subentendido se mostra condicionado aos tipos de perfis existentes. Como o observado no item 3.3 desta pesquisa, o modelo de criação de perfis em fóruns exige, inicialmente, um endereço de e-mail, uma foto, um nome de usuário e ocasionalmente uma descrição. Estes elementos identitários podem ser figurativamente idênticos aos elementos que o produtor possui no mundo das coisas, ou podem ser diferentes, como nomes-fantasia, desenhos e descrições fantasiosas.

A tendência observada nos fóruns analisados indica que os perfis que expõe sua figurativização como igual à do mundo real, utilizarão com mais frequência o subentendido, pois para os perfis, o subentendido cria a salvaguarda de que se "sou acusado de maledicência, sempre poderei proteger-me por trás do sentido literal de minhas palavras e deixar a meu interlocutor a responsabilidade da interpretação que delas faz" (DUCROT, 1987, p. 19). Vejamos a seguir um exemplo desta dinâmica:

Figura 68 - Comentário de Twitter e seus respectivos anexos. 


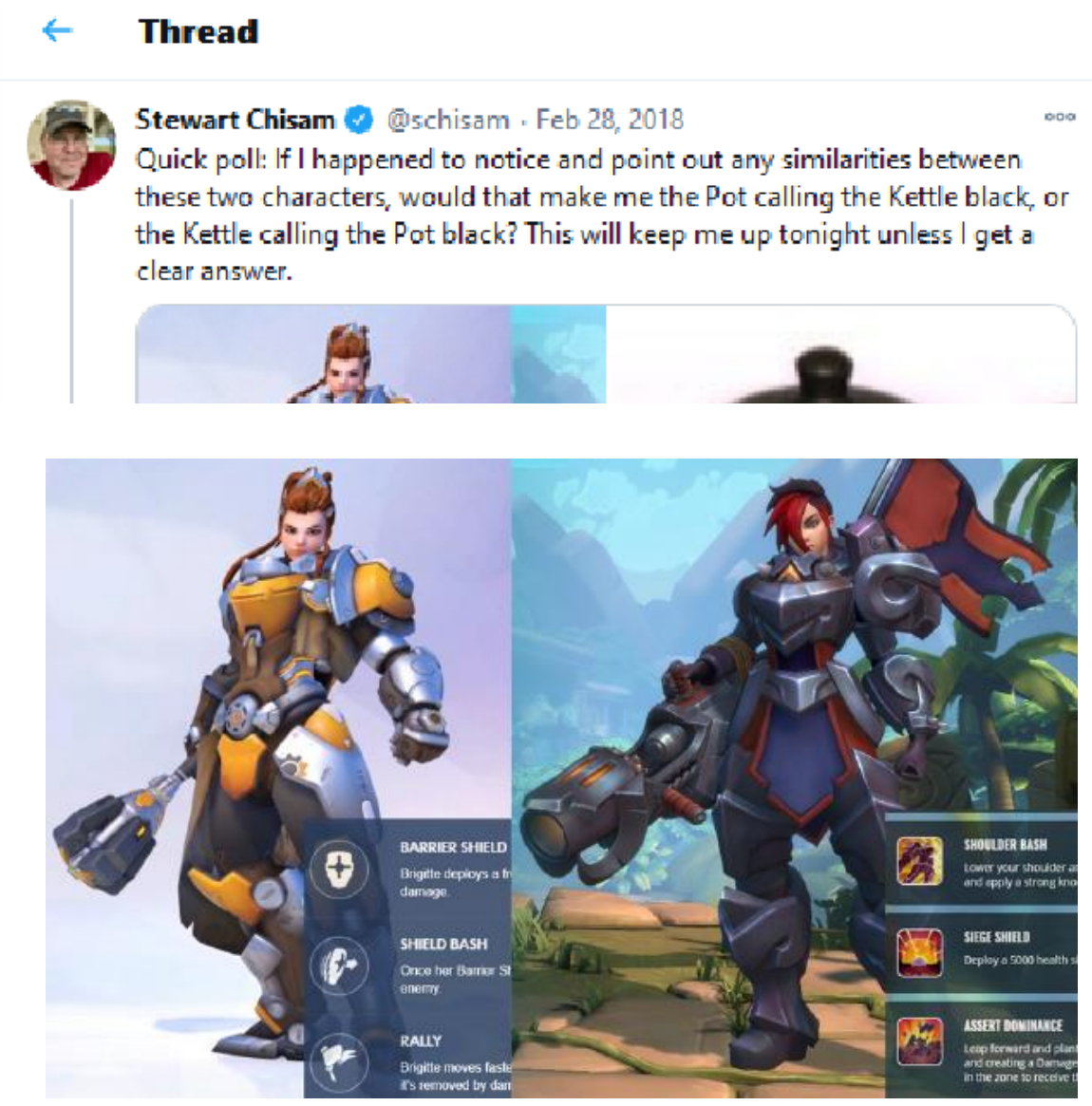

Fonte: Twitter $(2021)^{181}$.

Na imagem acima está uma postagem do perfil no Twitter de Steward Chisam, CEO da $\mathrm{Hi}$ Rez Studios, produtor de um jogo chamado Paladins, e sua postagem se traduz como "Pesquisa rápida: Se acontece de eu perceber similaridades entre estas duas personagens, isso seria o sujo falando do mal lavado, ou o mal lavado falando do sujo? Isso vai me manter acordado à noite até que eu encontre uma resposta ${ }^{182}$ ',

${ }^{181}$ Disponível em: <https://twitter.com/schisam/status/969032563384901632?ref_src=twsrc\%5Etfw\%7Ctwcamp\%5 Etweetembed\%7Ctwterm\%5E969032563384901632\%7Ctwgr\%5E\%7Ctwcon\%5Es1_\&re>. Acesso em: 10 mar. 2021.

182 O provérbio que o texto em inglês utiliza é "The Pot calling the Kettle black" e sua versão com a inversão dos atores. Esta expressão é constantemente utilizada para denotar a hipocrisia de uma pessoa ao acusar alguém de fazer algo que ela também faz. Esta pesquisa escolheu utilizar o provérbio português "o Sujo falando do Mal lavado", que conserva o sentido proposto. 
Anexada à mensagem, há uma imagem das personagens Brigitte (de Overwatch) e Ash (de Paladins) e suas respectivas habilidades principais. Ash foi lançada em Paladins em junho de 2017, enquanto Brigitte foi lançada em Overwatch em fevereiro de 2018. Como Paladins, por ser menos popular, foi classificado por jogadores como um "Clone de Overwatch"183, o subentendido proposto pelo perfil de Chisam é o de que os desenvolvedores de Overwatch teriam copiado sua personagem, o que explicaria também o uso do ditado popular ${ }^{184}$.

Devido a posição de Chisam no mercado de jogos, bem como as consequências que uma acusação indecorosa poderia gerar, o perfil Steward Chisam faz uso dos benefícios do subentendido. Porém, vejamos postagens de outros tipos de perfil, apresentadas a seguir:

Figura 69 - Comentários do site Reddit.

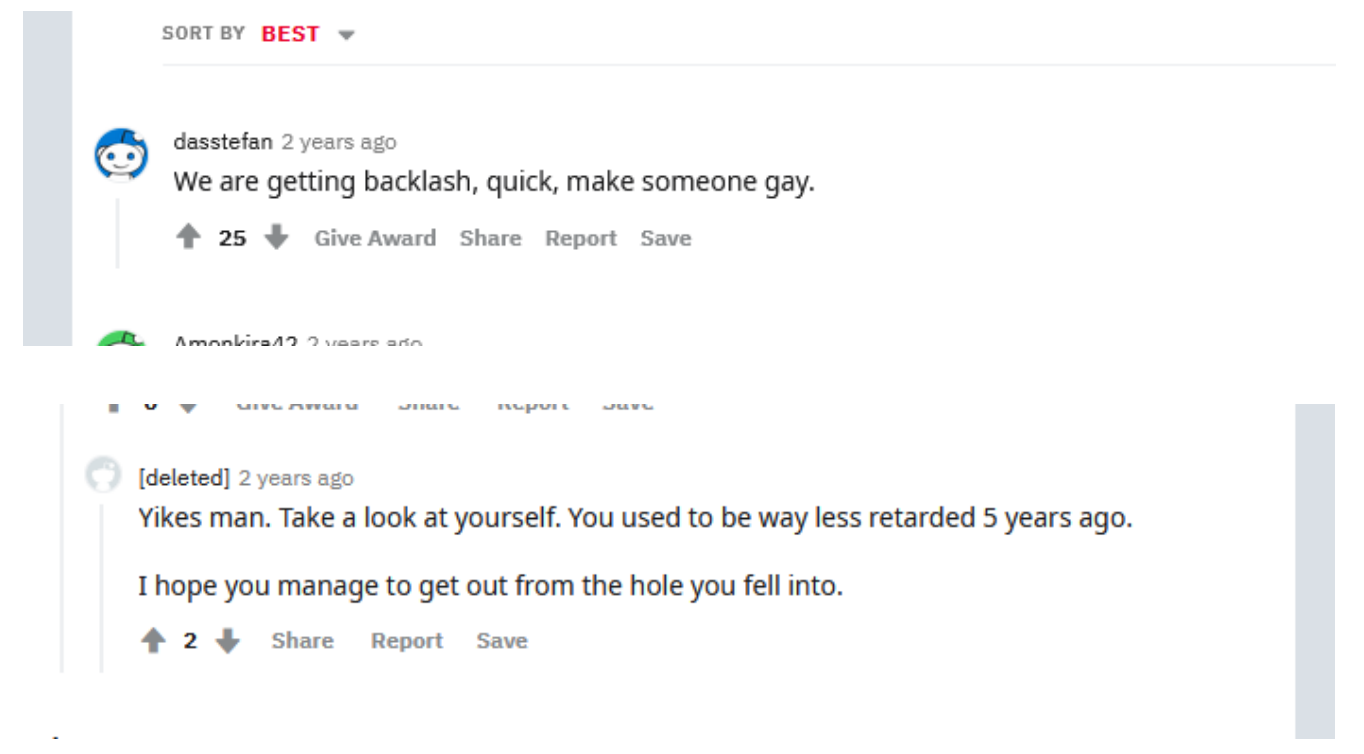

Fonte: Reddit $(2021)^{185}$.

183 D'ANASTASIO, Cecilia. The Overwatch-Paladins Clone Wars Continue. Kotaku. 03 jan. 2018. Disponivel em: <https://kotaku.com/the-Overwatch-paladins-clone-wars-continue-1823428873>. Acesso em: 21 jan. 2021.

${ }^{184}$ ANDREOZZI, Patrick. Overwatch: cinco polêmicas envolvendo o jogo de tiro da Blizzard. TechTudo. 27 abr. 2019. Disponível em: <https://www.techtudo.com.br/listas/2019/04/overwatch-cinco-polemicas-envolvendo-o-jogo-de-tiroda-blizzard.ghtml>. Acesso em: 20 jan. 2021.

185 Disponível em: <https://www.reddit.com/r/dotamasterrace/comments/aentke/soldier_76_is_gay_now_because_ lgbt_marketable/>. Acesso em: 10 mar. 2021. 
Ambas as postagens na imagem foram retiradas de uma thread no fórum Reddit a respeito do caso da sexualidade da personagem Soldado 76. Na parte de cima da imagem, a fala do perfil dasstefan pode ser traduzida como "Nós estamos recebendo críticas, rápido, transforme alguém em gay”, numa debreagem em que simula o raciocínio da empresa Blizzard. O comentário perfil deletado (que chamaremos de [deleted], pela ausência de conhecer seu nome original), mostrado na parte de baixo da imagem, pode ser traduzido como "Nossa cara, olhe para você. Você costumava ser menos retardado 5 anos atrás. Espero que você consiga sair desse buraco onde se enfiou”. Em resposta às discordâncias de outro perfil na thread.

Os comentários acima não possuem o uso de subentendidos pois suas afirmações são bem diretas. Isto acontece pois tanto o perfil dasstefan quanto o perfil [deleted] não possuem a necessidade, oferecida pelo subentendido, de proteção da face. Pois suas faces já estão protegidas pelos nomes-fantasia, ilustrações e descrições fantasiosas. A partir disso, eles podem opor-se a tentativas de validação e sanção dos discursos sem a necessidade de ater-se às boas práticas de interação.

Vale a pena observar um último ponto a respeito deste assunto: quando esta pesquisa se refere ao recobrimento figurativo com efeito do mundo das coisas ou não, esta não é a única regra que ajuda a separar os perfis pelo uso ou não de subentendidos. Existem nos fóruns perfis-fantasia que possuem uma base de seguidores ou um tempo gasto em sua construção, que faz com que tal perfil utilize subentendidos para preservação de sua face (mesmo que fantasiosa).

Estes exemplos de influência e elementos construtivos que abordamos são características do Ethos do enunciador. Perfis que apresentem figurativização correspondente ao mundo das coisas, ou que possuam longo período de atividade e base de seguidores possuem um Ethos mais positivo aos olhos da comunidade de fórum, em comparação a perfis com figurativização de fantasia ou sem muito destaque na comunidade, pois são mais descartáveis no caso de punições pelo abuso dos limites da civilidade discursiva. 


\subsubsection{A repetição como estratégia}

No decorrer dos últimos itens, esta pesquisa buscou apresentar algumas estratégias utilizadas na interação de fórum, do ponto de vista da sintaxe discursiva:

- A ambiguidade humorística, que permite que uma piada possa ser vista simultaneamente como crítica moralizadora ou comunhão regeneradora;

- A prática corrente dos fandoms de criar subgrupos dentro de uma mesma comunidade, com interpretações e teorias diversas do universo ficcional, e que necessitam do conflito como validação identitária;

- O princípio de leitura ergódica característico dos fóruns, que descentraliza o percurso narrativo, diversificando o processo de leitura entre os diversos fóruns analisados;

- O confronto ao discurso de autoridade, caracterizado pela recorrente invocação de anti-destinadores transcendentes, como forma de reenquadrar o discurso de autoridade como uma ação de agenda conspiratória;

- O uso extensivo de pressupostos, com o objetivo de desvirtuar discussões que proponham sanções e consequentes veridicções sobre certos discursos.

- Paralelamente ao uso "tradicional" de subentendidos, o completo abandono destes por parte de perfis descartáveis, que visam o ataque a um discurso divergente, para além das constrições sociais e estruturas de poder.

As estratégias aqui elencadas não representam a totalidade de estratégias interativas nos fóruns analisados, mas foram destacadas pela presente pesquisa pois convergem com o mesmo objetivo: dificultar um processo de sanção ao sentido de um discurso, o que, num segundo momento, dificulta também o reconhecimento do regime veridictório deste mesmo discurso.

É importante lembrar que, no caso do corpus analisado, tal ausência de sanção já é fortalecida pelo modo como os universos dos jogos ao qual estes fóruns se referem são construídos, lugares onde a não-sanção é oferecida à comunidade de fãs como uma oportunidade de 
engajamento (como descrito no item 2.5.2 desta pesquisa). Para suprir o enfraquecimento dos processos veridictórios tradicionais, esta pesquisa observa a utilização mais intensa de outro tipo específico de estratégia de criação de consenso em discurso: a repetição.

Em seu artigo "A complexidade discursiva na Internet”, na revista CASA, Pessoa de Barros observa que os discursos da internet possuem posições intermediárias entre elementos de fala (subjetividade, efemeridade, incompletude, cumplicidade e personalidade) e escrita (objetividade, duratividade, completude, individualidade e rigidez), em relação às características espaciais, temporais e actoriais do discurso. Porém, a autora afirma que:

Os discursos na internet dão maior tonicidade a algumas características da fala, mais intensa do que a escrita, como no caso da interatividade, e, ao mesmo tempo, aumentam a extensão da escrita, que dura mais, que não é passageira como a fala, e estendem, assim, seu alcance comunicacional (BARROS, 2019, p. 19)

Ao pensar na interação na internet como possuindo a intensidade e a dinâmica da fala, podemos observar os fenômenos da repetição em fóruns a partir do referencial da linguista Deborah Tannen, que em seu livro Talking Voices: Repetition, Dialogue, and Imagery in Conversational Discourse (2007), observa as dinâmicas de repetição ${ }^{186}$ dentro de diálogos falados.

Segundo o trabalho de Tannen, em linhas gerais, a repetição na linguagem "funciona para criar significado e negociar relações" (p. 15 - tradução nossa). O significado, segundo a autora, não é derivado diretamente das expressões usadas, ou pela desconstrução e definição dos termos, mas pela associação entre termos e frases do repertório do enunciador/enunciatário.

Tannen enumera diversos motivos pelos quais a repetição é considerada uma ocorrência comum na linguagem falada: a repetição de parte de uma frase permite ao ouvinte se concentrar

\footnotetext{
186 Em seu livro, Tannen faz diferenciações terminológicas entre Repetição (uma pessoa repete o próprio discurso) e Allo-Repetição (uma pessoa repete o discurso de outrem). A autora também difere repetição (repetition), onde se repetem as mesmas palavras, reciclagem (reciclying), onde se repete o assunto do discurso em outro momento, ressignificação (reframing), onde repete-se o assunto e as palavras, mas muda-se o foco do tema, e recriação (rekeying) uma repetição de uma discussão, mas com uma mudança no tom. Para a presente pesquisa, todas estas modalidades serão agrupadas como repetição, pois é o conceito geral de repetição em diálogo que interessa à pesquisa, e a autora vê todos estes elementos como responsáveis pela "evolução do discurso" (2007, p. 24 - tradução nossa).
} 
apenas nos elementos novos do discurso, bem como permite que se "ganhe tempo" para a formulação de outros argumentos.

Outros pontos levantados pela autora possuem ainda mais relevância para o objeto desta pesquisa: a repetição se apresenta como uma forma de aperfeiçoamento do discurso. Diz a autora, a respeito de uma história ouvida de uma de suas fontes:

Ela contou esta história antes, e irá contá-la de novo, e quando ela o fizer, ela vai usar uma variação da mesma sentença porque esta encapsulará para ela o que foi mais memorável e mais descritível sobre aquela experiência. Neste sentido, no momento em que ela contar esta história, ela irá repetir a sentença de seu próprio discurso anterior (TANNEN, 2007, p. 65 - tradução nossa)

Também é apontado por Tannen como uma função da repetição em diálogo a aprovação de um discurso (repete-se um discurso para dar-lhe aval durante o diálogo), bem como para mostrar o engajamento na conversa. A técnica de sombreamento (shadowing - repetir uma frase poucos instantes após o início de sua enunciação) é, segundo Tannen, uma estratégia comum para que um participante se mostre inserido na conversa e no tema, mesmo que ele não possua nada para incluir "permitindo ao falante tomar parte, relativamente sem esforço, na conversação" (p. 96 - tradução nossa).

A partir destes princípios, a proposta desta pesquisa é a de que, enquanto a eficácia dos modos tradicionais de sanção e veridicção é diminuída em função das estratégias descritas acima, a repetição dentro dos fóruns se apresenta como uma ferramenta de maior eficácia para a criação dos efeitos de sanção e veridicção.

Para justificar esta proposta, esta pesquisa observa que a própria Tannen se refere ao poder de criação de repertório comum através da repetição. No contexto da conversação, a repetição auxilia na cristalização de figuras e temas, bem como cria a sensação de proximidade entre enunciador e enunciatário:

Uma forma de participação comum no estabelecimento de sentido é a criação de imagens: tanto o falante que descreve ou sugere uma imagem com palavra, quanto o leitor ou ouvinte que cria tais imagens baseados naquela descrição ou sugestão (TANNEN, 2007, p. 134 - tradução nossa) 
A criação de imagens na fala, através de repetições e allo-repetições possui um sentido similar à utilização de temas e figuras nos discursos escritos. Para além das observações de Tannen, as observações sobre o funcionamento do continuиm memético, feitas no item 3.6 desta pesquisa, bem como o apontamento da utilização de tropes e temas advindos da manifestação cultural dominante, observados nos itens 2.6.2 e 2.6.3, corroboram a importância da repetição na criação e cristalização de temas e figuras dentro dos espaços de fórum analisados.

Utilizando a semiótica Tensiva, Luiz Tatit (2010) em suas análises semióticas das obras de Guimarães Rosa, observa efeitos similares aos descritos neste item, aos quais chama de práticas impregnantes:

Atos que se somam no campo de percepção do sujeito comprometendo sua capacidade de dar respostas parciais a cada um deles [...] O efeito de todo esse processo é semelhante ao acontecimento inesperado que surpreende o sujeito e lhe rouba momentaneamente a capacidade de reagir. Como se trata, porém, de um acontecimento extenso, prolongado, o efeito do impacto também tende a permanecer e, até mesmo, a recrudescer em virtude das novas ocorrências (TATIT, 2010, p. 117)

Como observado no decorrer deste item, a repetição em fórum ocorre em conjunto à ausência de sanções, e, dado ao fato de que cada percurso ergódico que cada enunciatário/enunciador percorre no conjunto "jogo+fóruns" é diverso, não é possível de se estabelecer o projeto de significado geral, que daria sentido a tais repetições ${ }^{187}$.

Uma última observação a respeito da repetição dentro do espaço do fórum refere-se à dinâmica de comportamentos conspiratórios, observada com mais detalhe no item 4.2 .4 desta pesquisa. As observações de Tatit a respeito das práticas impregnantes propõe que:

A longa duração das práticas impregnantes ocasiona em geral um efeito suplementar: ao se sentir cada vez mais tomado por sinais estranhos a seu cotidiano, o sujeito começa a suspeitar daquilo que considera como sua "realidade". A frequência com que recebe os estímulos de um universo a princípio fora do comum passa a configurar uma espécie de cotidiano concorrente que acusa a existência de uma realidade paralela. Em outras palavras, o aspecto extraordinário que normalmente define um acontecimento ameaça tornar-se

${ }^{187}$ Este projeto global é, entretanto, proposto na forma de estruturas conspiratórias, como será descrito mais a frente, neste mesmo item. 
ordinário, habitual e, mais uma vez, extensivo ao indivíduo como um todo, visto que poderá eventualmente conduzir sua vida diária. (TATIT, 2010, p. 118).

O que esta pesquisa propõe, a partir da leitura dos autores levantados, é que as repetições em fórum podem ser vistas como práticas impregnantes, como descritas por Tatit, que são possíveis graças às características de ambiguidade discursiva e dificuldade de sanções e veridicções dos espaços de fórum. Aliados aos efeitos da repetição nas dinâmicas da fala, propostos por Tannen, esta repetição acaba por criar um efeito de sanção, que compensa o enfraquecimento sanção discursiva e o consequente estabelecimento de regimes de veridicção.

Este recrudescimento (Tatit) e aproximação entre os enunciadores que se repetem (Tannen), aliados aos combates aos sancionamentos (item 4.2.4) e a proposta do universo ficcional de se apresentar como uma metáfora do mundo e sua diversidade (item 2.6.2), permite a aceitação do que, até então, era um conjunto considerado irreal, e que esta pesquisa vê como um discurso conspiratório.

Por fim, esta pesquisa irá analisar agora os elementos semânticos do discurso nos fóruns presentes no corpus, e observar como estes elementos se integram com os sistemas sintáxicos propostos acima.

\subsection{Elementos semânticos do discurso em fórum}

\subsubsection{Identidades desenvolvidas por fãs}

D.Va (pronuncia-se "diva"), uma personagem de Overwatch e lançada em 6 de novembro de 2015. Sua descrição geral na wiki de Overwatch é a seguinte:

Figura 70 - Descrição de D.Va na wiki de Overwatch. 


\section{STORY}

D.Va is a former professional gamer who now uses her skills to pilot a state-of-the-art mech in defense of her homeland. [2] She is a very competitive individual, ${ }^{[3]}$ and coupled with her progamer skills, this makes her an extremely effective mech pilot. Never backing down, D.Va always plays to win. ${ }^{[4]}$ While she projects a carefree, irreverant attitude, D.Va is burdened by the emotional cost of defending her homeland, and the facade the South Korean media projects on

her.

In addition to skills as a mech pilot, D.Va is also a competent mechanic. [5]

Fonte: Gamepedia $(2021)^{188}$.

A tradução desta apresentação inicial é:

D.Va é uma ex-gamer profissional que agora usa suas habilidades para pilotar um robô avançado em defesa da sua terra natal. Ela é um indivíduo competitivo, o que junto com suas habilidades de gamer profissional, faz dela uma piloto de robôs eficaz. Nunca recuando, D.Va sempre joga para vencer. Enquanto ela projeta uma atitude tranquila e irreverente, D.Va é pressionada pelo custo emocional de defender sua terra natal, e pela fachada que a mídia sul-coreana projeta sobre ela. Além de suas habilidades como piloto de robôs, D.Va é também uma competente mecânica.

Com o tempo, fãs dos fóruns de Overwatch passaram a apresentar a personagem como um estereótipo de um gamer ${ }^{189}$ tóxico, adicionando elementos em seus comentários e artes como um consumo excessivo de produtos industrializados, um comportamento histérico, violento e imaturo. Sua aparência física passou a ser apresentada com um desenho estilizado: corpo pequeno, cabeça grande expressões característica da estética de mangá, que denotam aparência de sadismo. Esta representação da personagem acabou sendo nomeada pelos fãs como "Gremlin D.Va" ou "Umaru D.Va". Os dois exemplos iniciais mostrados abaixo (apresentando relações de ratio difficilis com a personagem) foram lançados no site Dambooru em junho de 2016.

Figura 71 - Ilustrações da personagem D.Va.

${ }^{188}$ Disponível em: 〈https://overwatch.gamepedia.com/D.Va〉. Acesso em: 10 mar. 2021.

189 É interessante notar que, neste caso, a atribuição da personagem como sendo sul-coreana também conta para esta leitura, já que a Coréia do Sul possui grande relevância nos e-sports e na cultura gamer como um todo. Ver GAYATRI, D; RAJSHEKAR, N. South Korea: Making of a Game Industry. Case Centre. 2004. Disponível em: <https://www.thecasecentre.org/programmeAdmin/products/view?id=19677>. Acesso em: 15 jan. 2021. 

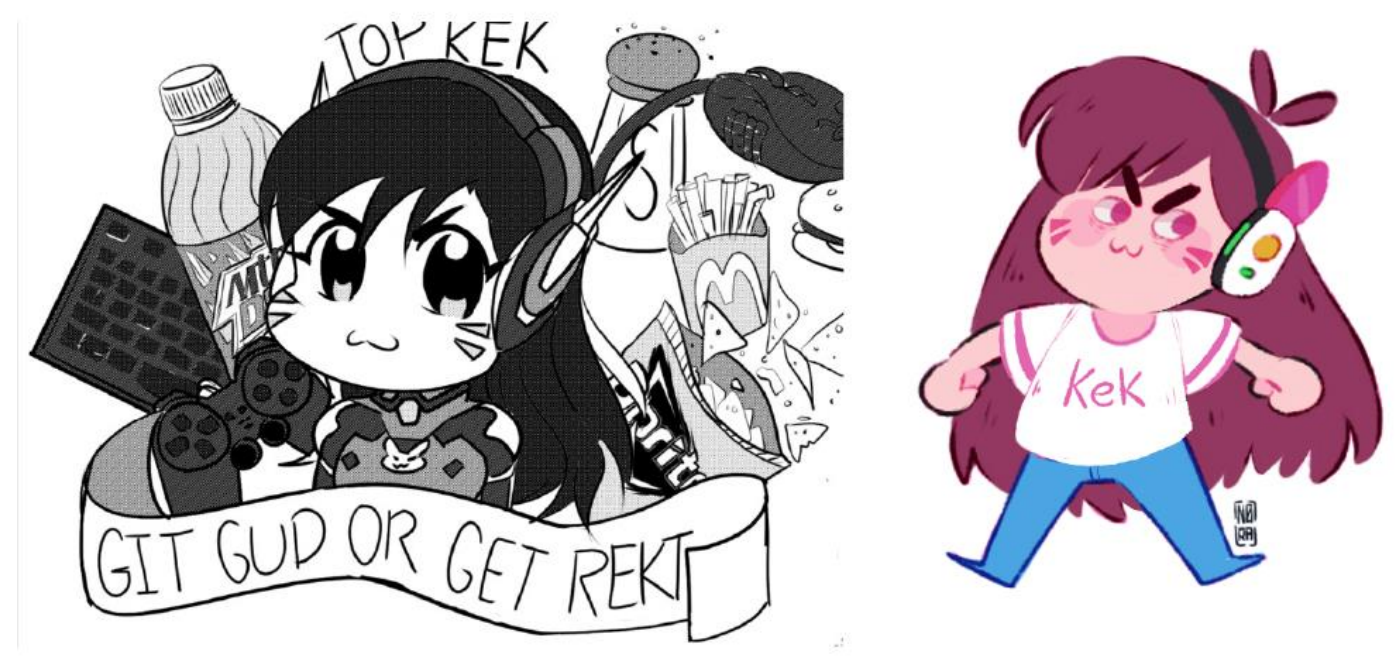

Fonte: Danbooru $(2021)^{190}$.

Em concordância com o que esta pesquisa analisou no item 3.6 e 3.7, à medida que este punctum memético se espalha e se multiplica dentro dos fóruns, artes e piadas mais complexas e cristalizadas (do tipo ratio facilis) começam a surgir. Os exemplos abaixo foram lançados no site Dambooru entre julho de 2016 e setembro de 2017.

Figura 72 - Ilustrações da personagem D.Va.

${ }^{190}$ Disponível em: <https://danbooru.donmai.us/posts?tags=d.va_\%28gremlin\%29>. Acesso em: 10 mar. 2021. 


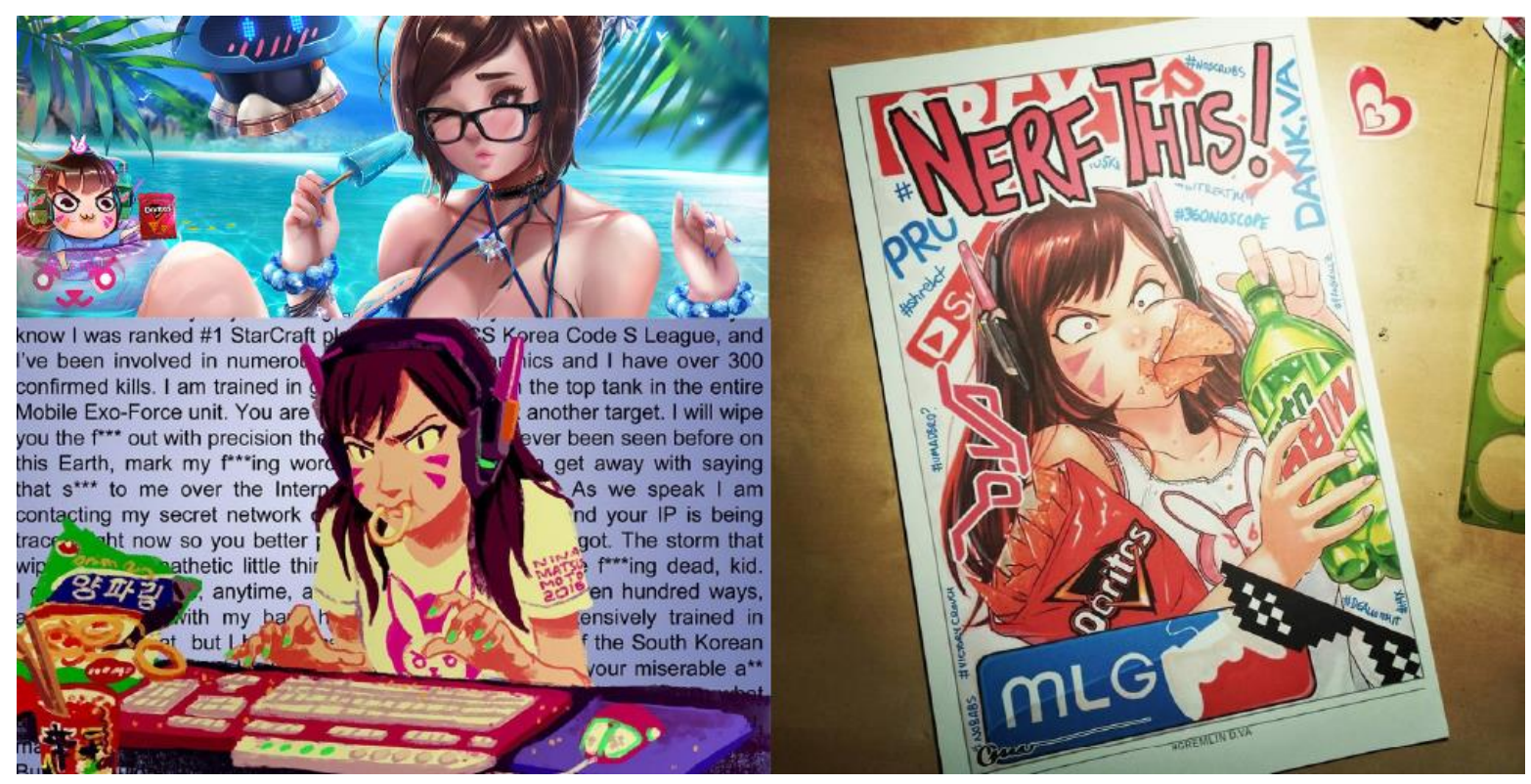

Fonte: Danbooru $(2021)^{191}$.

Em função da popularidade desta "versão" da personagem dentro dos fóruns de Overwatch, acabou-se criando dentro do fórum Dambooru a $\operatorname{tag}^{192}$ de pesquisa " $D . V a$ (gremlin)", que permite que se busquem todas as imagens do fórum que algum usuário identificasse como dotada de alguma representação desta versão da personagem.

Figura 73 - Tags de pesquisa numa imagem apresentando a personagem D.Va.

: slailiail $<\angle J$

\section{Characters \\ ? d.va (gremlin) 78 \\ ? d.va (overwatch) $4.2 \mathrm{k}$}

\section{General}

? 1 girl 3032k

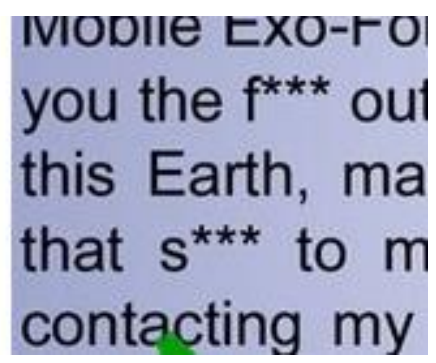

Fonte: Danbooru $(2021)^{193}$.

${ }^{191}$ Disponível em: <https://danbooru.donmai.us/posts?tags=d.va_\%28gremlin\%29>. Acesso em: 10 mar. 2021.

${ }^{192}$ Tag é o termo usado para uma palavra que, adicionada nos metadados de um arquivo digital, permite que este arquivo seja buscado via hiperlinks. Descrito em detalhes no glossário no fim da dissertação.

${ }^{193}$ Disponível em: <https://danbooru.donmai.us/posts/2403508>. Acesso em: 10 mar. 2021. 


\subsubsection{Identidades complexas e compartilhamento de semas}

No exemplo do item anterior, um elemento importante a ser destacado é que a tag " $\mathrm{D}$.Va (gremlin)" não sobrepõe ou substitui a tag "D.va (Overwatch)", pois esta é associada à representação canônica ${ }^{194}$ da personagem. Ambas aparecem simultaneamente numa mesma imagem ou texto. Doravante, esta pesquisa usará esses dois termos para se referir a ambas as acepções da personagem, encontradas nos fóruns do corpus desta pesquisa.

Para estruturar esta relação, esta pesquisa propõe a análise sêmica destes dois termos, análise esta proposta a partir do trabalho do linguista francês Bernard Pottier. Em seu livro Linguística geral: Teoria e descrição, o autor para um sema e um semema é a seguinte:

Cada traço considerado como distintivo relativamente a um conjunto é um sema. O conjunto dos semas que caracterizam um morfema é o semema: $\left\{\mathrm{sema}^{1}, \mathrm{sema}^{2}\right.$, ... sema ${ }^{\mathrm{n}}$ \}. (POTTIER, 1987, p. 62)

A partir desta explicação, vemos que estes traços/semas (alto, verde, baixo, cruel...) se agrupam em sememas ${ }^{195}$, que são como "descrições" do significado de um morfema ${ }^{196}$ (exemplo: Cadeira - superfície plana acima do solo, para sentar, com encosto) (ibid, p.63).

Para analisar estes radicais de significado, Pottier propõe o uso da Análise Sêmica, em que os morfemas são definidos pela combinação ou exclusão sêmica entre ele e outros morfemas de significado próximo. Abaixo vemos um exemplo desta análise sêmica, utilizada pelo autor para a definição de veículos:

Figura 74 - Exemplo de análise sêmica.

\footnotetext{
194 Canônico é o termo usado para definir as informações “oficiais" de um elemento dos jogos. Descrito em detalhes no glossário no fim da dissertação.

195 Semema é um conjunto de semas, que denota a acepção específica de uma palavra. Descrito em detalhes no glossário no fim da dissertação.

196 Morfema é a palavra, vista do sentido morfológico. Descrito em detalhes no glossário no fim da dissertação.
} 


\begin{tabular}{|c|c|c|c|c|c|c|c|c|}
\hline & $\begin{array}{c}\text { Anda sobre } \\
\text { a terra }\end{array}$ & $\begin{array}{c}\text { Anda sobre } \\
\text { trilhos }\end{array}$ & $\begin{array}{c}\text { Anda sobre } \\
\text { duas rodas }\end{array}$ & $\begin{array}{c}\text { Transporte } \\
\text { individual }\end{array}$ & $\begin{array}{c}\text { Transporte } \\
\text { pago }\end{array}$ & $\begin{array}{c}\text { Transporta } \\
\text { 4a } 6 \text { pessoas }\end{array}$ & $\begin{array}{c}\text { Transporte } \\
\text { inter-urbano }\end{array}$ & $\begin{array}{c}\text { Transporte } \\
\text { de pessoas }\end{array}$ \\
\hline TAXI & SIM & NÃO & NÃO & indiferente & SIM & SIM & indiferente & SIM \\
\hline ONIBUS & SIM & NÃO & NÃO & NÃO & SIM & NÃO & SIM & SIM \\
\hline CARRO & SIM & NÃO & NÃO & NÃO & SIM & NÃO & NÃO & SIM \\
\hline MOTO & SIM & NÃO & SIM & SIM & NÃO & NÃO & indiferente & SIM \\
\hline TREM & SIM & SIM & NÃO & NÃO & SIM & NÃO & NÃO & SIM \\
\hline AVIÃO & NÃO & NÃO & NÃO & indiferente & SIM & indiferente & NÃO & SIM \\
\hline
\end{tabular}

Fonte: imagem nossa, adaptada de Pottier (1978).

No Dicionário de Semiótica, foram propostas atualizações a respeito da terminologia utilizada neste tipo de análise. É observado que a análise sêmica em si possui o problema de que a falta de estrutura na escolha dos semas utilizados na análise pode ocasionar um deslize para um campo psicologizante. Os autores afirmam que a capacidade da análise sêmica é a de uma “disciplina autônoma, com sua própria especificidade, e, em contrapartida, com um domínio de aplicação limitado, (GREIMAS \& COURTÉS, 2008, p. 443-444)

Levando em consideração as observações dos autores, esta pesquisa crê que o uso da análise sêmica se mostra como uma das aplicações possíveis. A partir das observações dos capítulos anteriores, a natureza pessoal da leitura ergódica, a identificação de semas através da repetição, o intenso uso de tecnoletos e metáforas e o próprio contexto de manifestação cultural dominante da internet acabam por justificar o risco da abordagem "psicologizante" da análise sêmica, pois incluem os valores e ideologias característicos dos textos-contextos de jogo e fórum, o que é parte integrante da presente pesquisa.

Propõe-se uma análise sêmica para a observação das tags $D . V a$ (gremlin) e $D . V a$ (overwatch). Porém, para fins de exposição, será proposto um layout diferente de apresentação, para destacar os termos mais relevantes, mantendo porém o objetivo proposto por Pottier de destaque dos semas diferenciais e comuns para cada palavra.

Ainda sobre esta análise sêmica, é importante que sejam feitas algumas considerações. Greimas e Courtés (2008) propõe atualizações nas definições de sema, semema e lexema, que esta pesquisa pretende levar em consideração. 
Quanto aos semas, os autores observam que, apesar de seu caráter de "unidade mínima" proposto por Pottier, o sema deve ser visto como um elemento de natureza relacional, e não atômico/autônomo. Os semas são delimitados de maneira arbitrária e no momento da análise e, portanto, são a unidade mínima de sentido dentro do campo de exploração escolhido.

Os autores também propõem uma terminologia categórica de semas:

- $\quad$ Semas Figurativos: Grandezas no plano de conteúdo das línguas naturais, referente às articulações das qualidades sensíveis e sensoriais do mundo das coisas.

- Semas Abstratos: Grandezas de conteúdo que, ao contrário dos semas figurativos, categorizam o mundo e lhe dão significação. São semas abstratos categorias relação/termo e objeto/processo.

- Semas Tímicos: São os semas que se encaixam dentro da categoria euforia/disforia, sendo microssistemas sêmicos de valor axiológico.

Esta pesquisa propõe ainda, em relação ao objeto analisado, o uso de uma quarta categoria sêmica, que foi proposta por Pottier em sua obra, chamada Virtuema. De acordo com o autor, este termo denomina:

Todo elemento que é latente na memória associativa do falante e cuja atualização está ligada aos fatores variáveis das circunstâncias da comunicação. O virtuema representa a parte conotativa do semema. É muito dependente das aquisições sócio-culturais dos interlocutores. É, portanto, instável, mas se situa na competência em um momento dado. (POTTIER, 1978, p. 74-75)

Enquanto Greimas e Courtés, com razão, observam que a noção de virtuema é problemática, pois considera que é possível reconhecer tais elementos objetivamente, a presente pesquisa propõe o uso de virtuema para definir semas que possuam um sentido apenas compreensível através do entendimento dos tecnoletos presentes no jogo e no fórum. A respeito do virtuema, o autor reforça que "Essa liberdade associativa alcançará seu máximo se se propõe um termo desconhecido do ouvinte" (POTTIER, 1978, p. 77).

A partir da premissa que tecnoletos não podem ser elevados ao mesmo nível de uma linguagem, por sua aplicação limitada, tanto temporalmente quanto espacialmente, esta pesquisa 
reservará o termo virtuema aos semas cujo sentido é intrínseco ao universo do jogo, ultrapassando apenas sua utilidade como metáfora.

A respeito dos sememas, os autores do Dicionário de Semiótica observam que são adequados para definir uma acepção de uma palavra, enquanto à palavra em si, os autores sugerem o uso do termo lexema. Desta forma, "O lexema - enquanto reunião de sememas - é, como se vê, o resultado do desenvolvimento histórico de uma língua natural, enquanto o semema é um fato estrutural, uma unidade do plano do conteúdo" (GREIMAS \& COURTÉS, 2008, p. 441). Os sememas, possuem um núcleo, que são os seus elementos diferenciais e exclusivos, enquanto os demais semas são contextuais, vindos do texto onde o núcleo é utilizado.

Um exemplo desta construção terminológica é o lexema "cachorro", que pode possuir os sememas "animal mamífero quadrúpede, da família dos canídeos e domesticado pelo homem” e "homem infiel e sem caráter", a depender do texto. É importante observar que o semema não é uma unidade de significação do signo mínimo:

É no momento de sua manifestação no discurso que essa figura alcança sua base classemática (constituída de semas contextuais) e seleciona assim um percurso semêmico que realiza como semema, com exclusão de outros percursos possíveis, os quais, tendo permanecido virtuais, são suscetíveis de produzir, em outros contextos discursivos, outros sememas de um mesmo lexema (GREIMAS \& COURTÉS, 2008, p. 441-442)

Feitas as considerações necessárias a respeito da terminologia que esta pesquisa aplicará nas análises sêmicas propostas, é apresentada a seguir a análise de dois sememas do lexema D.Va, aqui chamados de D.Va (overwatch) e D.Va (gremlin):

Figura 75 - Análise Sêmica de D.Va (overwatch) e D.Va (gremlin). 


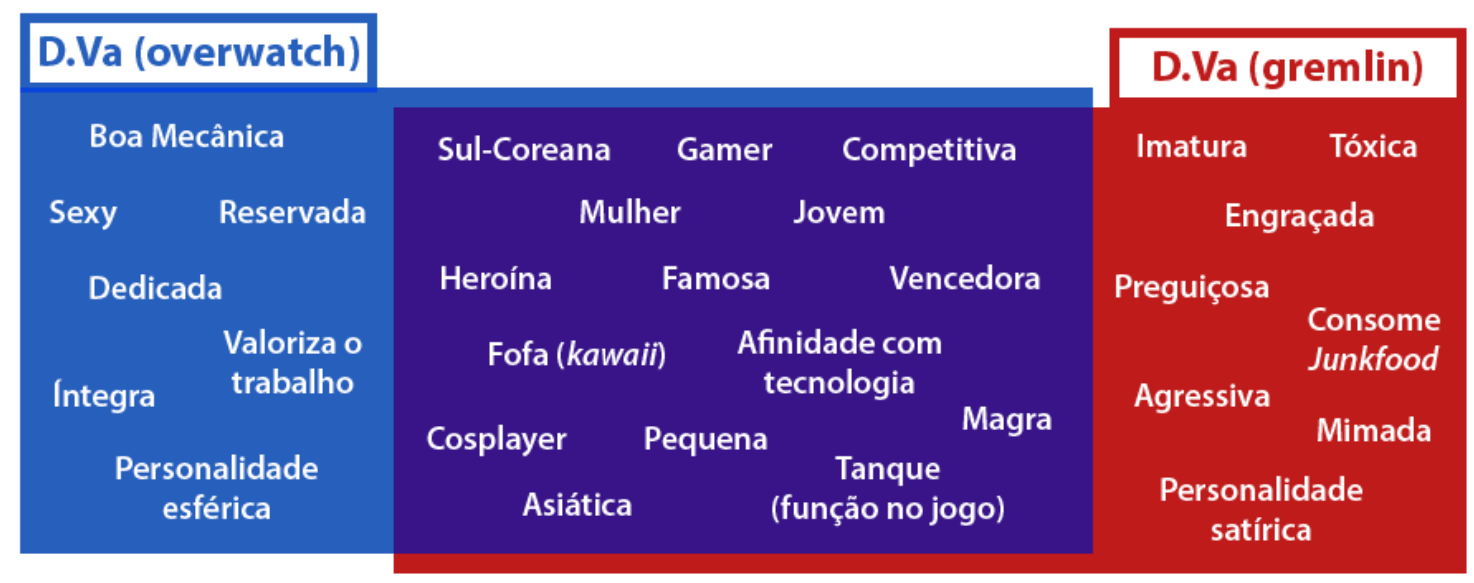

Fonte: imagem nossa.

Esta pesquisa propõe a comparação de dois sememas distintos pois, apesar da observação feita anteriormente, sobre o percurso semêmico, a leitura ergódica, a repetição em espaço de fórum e a estética de incompletude observadas nos capítulos 2 e 3, criam diversas leituras "incompletas" dentro do sistema contextual jogo-fórum. É possível se considerar que ambos os sememas aparecem simultaneamente dentro do texto-contexto fórum, sendo esta comparação entre ambos os sememas válida apenas para o tipo de texto analisado, segundo proposta aqui levada a efeito.

Os termos do semema D.Va (overwatch) possuem alguns semas, como Sul-Coreana, Gamer, Dedicada, Competitiva e Jovem, por exemplo. Esses semas fortalecem-se pelo contexto cultural da predominância de gamers profissionais sul-coreanos na comunidade de jogadores, como apontado anteriormente neste item. O simples fato de os jogos analisados criarem representações metafóricas de diversas culturas globais, propicia o uso de associações culturais (itens 2.6.2 e 2.6.3), fundamental ao funcionamento dos semas tímicos e virtuemas. É importante lembrar que, como contexto cultural, esta pesquisa considera as dominâncias e conflitos descritos a respeito da manifestação cultural dominante, proposto no item 2.6.2.

Analogamente, a comunidade de jogadores e fãs que habita o fórum também se utiliza dos mesmos recursos. Os semas do semema D.Va (gremlin): Gamer, Competitiva, Tóxica, Imatura e Engraçada são também fortalecidos pelo contexto cultural, em que o atual comportamento eufórico 
e irônico da comunidade de gamers acaba por criar episódios de agressividade e comportamento tóxico ${ }^{197}$.

Enquanto todas as palavras utilizadas no fórum são afetadas por esta dinâmica, esta pesquisa dará destaque aos termos da linguagem códica e seus tecnoletos: os personagens, localizações, ações e outros termos, que são palavras que circulam apenas dentro dos jogos e seus fóruns, e se apresentam como espaço privilegiado para manipulação de sentido por parte do fandom dos fóruns.

Ainda que os sememas D.Va (overwatch) e D.Va (gremlin) sejam diferenciáveis a partir de seus núcleos, como observado na análise sêmica, eles permanecem vinculados pelo lexema comum D.Va. Porém, dentro da dinâmica do fórum, o semema D.Va (overwatch) possui a capacidade de influir mais diretamente sobre o semema $D$.Va (gremlin) do que o contrário $^{198}$, já que o primeiro é estabelecido pela desenvolvedora, enquanto o segundo é resultado da dinâmica de repetição dentro do espaço de fórum, portanto de mais difícil cristalização dentro do tecnoleto corrente nos espaços de fórum.

Desenhada esta proposta de análise sêmica dos lexemas e sememas do universo dos fóruns e jogos analisados, cabe agora explicar como funcionam as estratégias discursivas em fórum relativo aos semas.

Num artigo chamado "A Estrutura semântica", presente no livro Sobre o Sentido: ensaios semióticos (1975), A.J. Greimas faz um estudo sobre as estruturas semânticas, o autor descreve-a da seguinte forma:

A estrutura semântica aparece então como uma combinatória virtual porém exaustiva de categorias sêmicas, enquanto que os usos e as performances semânticas correspondem a manifestações restritas, particularizadas sob a forma das culturas e personalidades. Dois enfoques paralelos, mas diferentes, se fazem

${ }^{197}$ RATAN, Rabindra; SHEN, Cuihua; WILLIAMS, Dmitri. Toxicity in Gaming is Dangerous. Here's How to Stand Up to It. Wired. 12 set. 2020. Disponível em: <https://www.wired.com/story/toxicity-in-gaming-is-dangerous-hereshow-to-stand-up-to-it/>. Acesso em: 28 jan. 2021.

198 Mas é importante ressaltar que, como observado no item 2.6.3, que caso uma interpretação feita pelos fãs se torne muito popular, não é incomum que os desenvolvedores acenem em reconhecimento a esta interpretação (com skins ou Easter Eggs), ou mesmo que assumam essa informação, colocando-a na narrativa canônica do universo de fantasia. Este, aliás é o caminho almejado por uma boa parcela de fãs: alçar suas interpretações a elementos canônicos da narrativa. 
possíveis: a) uma exploração de universos semânticos virtuais e abertos, considerados como possibilidades criativas do homem; b) uma descrição de universos semânticos passados ou presentes, mas restritos e realizados, que recubram o conjunto das dimensões históricas e tipológicas da humanidade (GREIMAS, 1975, p. 38).

Para uma organização desta dualidade de enfoques, Greimas propõe dois termos distintos: forma semiótica e forma científica. Para apresentar a diferença entre ambos, o autor recorre a exemplos:

Se se reconhece a existência de uma forma específica, própria a cada substância utilizada no plano da expressão, deve-se aceitar ao mesmo tempo que a forma que se chamará semiótica da substância seja diferente da forma científica da mesma substância: se, por exemplo, a química enquanto ciência é uma organização formal específica a um domínio dado de substância, logo os elementos químicos são as unidades mínimas (= os traços distintivos) cuja combinatória produz, no plano da manifestação, um dos aspectos do que se chama, por falta de um termo mais apropriado, o mundo do senso comum. A química é uma forma científica cuja manifestação superficial é utilizada, a partir de uma nova articulação, para a construção da forma semiótica que, através de todos os tipos de linguagem, deve servir à expressão do sentido. (GREIMAS, 1975, p. 39)

Este princípio de análise da estrutura semântica esboçado por Greimas é retomado e refinado por Waldir Beividas, em seu livro Semióticas sincréticas: posições (a linguagem do cinema)(2015). Neste trabalho, Beividas busca aprofundar estas formas propostas por Greimas, com o objetivo de conceber princípios para o estabelecimento de objetos semióticos a partir de linguagens complexas, como o cinema.

O autor propõe um modelo triforme de linguagem: forma códica (ou forma linguística), forma semiótica e forma científica. Este modelo teria funcionamento tanto no plano da expressão quanto no plano do conteúdo. Quanto ao plano do conteúdo, foco da pesquisa nesse momento, a proposta da divisão de competências de cada forma é a seguinte:

No plano do conteúdo, se nos atemos à organização e descrição das categorias sêmicas como, por exemplo, a da espacialidade, estaríamos estabelecendo a forma científica da substância semântica; se nos atermos à estruturação semêmica (conjunto hierarquizado de semas), estamos estabelecendo a forma semiótica da substância semântica; por fim, se descrevemos o modo lexemático de como a língua natural resolve um semema (ex. "chuva" para / água que cai do céu/) estamos estabelecendo no lexema a forma linguistica da substância semântica. (BEIVIDAS, 2015, p. 102-103) 
Este sistema de análise, devidamente espelhado para o plano da expressão, dá origem ao diagrama a seguir:

Figura 76 - Modelo triforme de linguagem.

\begin{tabular}{|l|l|}
\hline \multirow{4}{*}{ CONTEÚDO } & Forma Científica \\
\cline { 2 - 2 } & Forma Semiótica \\
\cline { 2 - 2 } & Forma Códica \\
\hline \multirow{3}{*}{ EXPRESSÃO } & Forma Códica \\
\cline { 2 - 2 } & Forma Semiótica \\
\cline { 2 - 2 } & Forma Científica \\
\hline
\end{tabular}

Fonte: imagem nossa, adaptada de Beividas (2015)

É interessante notar que, para Beividas, o quadrado semiótico do nível fundamental, enquanto dispositivo, seria a forma científica do discurso de uma linguagem, enquanto o investimento valorativo e antropomórfico dos semas axiologizados estaria já no domínio da forma semiótica.

Voltando ao tema dos lexemas e sememas utilizados nos jogos analisados, esta pesquisa crê serem fundamentais na compreensão as formas científica e semiótica. A forma científica é, se considerarmos os exemplos de Greimas e Beividas, a instância em que as unidades de sentido são estabelecidas, ou seja, estabelece-se o que pode ser nomeável.

Esta pesquisa propõe que, a partir da premissa, analisada no item 2.6.3, de que o universo fictício simula, através de metáforas, o mundo real e, portanto, possui um pseudociência ${ }^{199}$, que acaba por criar os tecnoletos e os neologismos usados nos jogos e nos fóruns, para definir conceitos necessários ao desenvolvimento do enredo.

${ }^{199}$ O raciocínio aqui proposto poderia ser expandido, afirmando-se que o universo de fantasia dos jogos possui uma pseudo-física, uma pseudo-química, uma pseudo-política etc. Porém tal detalhamento não é útil pois cada uma destas pseudo-ciências operaria sob as mesmas funções, simular suas contrapartes do mundo das coisas, se utilizando de elementos idênticos, elementos metafóricos e elementos narrativos, criando neologismos e tecnoletos quando necessário. Esta pesquisa portanto propõe agrupar todos estes funcionamentos similares no termo pseudociência. 
Como exemplo destes termos, podemos mostrar que, em Overwatch, existem os ômnicos, uma raça robótica que possui inteligência artificial e divide o mundo com os seres humanos. Esta palavra, que define "uma raça não-humana e sintética" não existe no léxico do mundo das coisas, mas foi desenvolvida para atender às necessidades do enredo e suas metáforas ${ }^{200}$. Umberto Eco (2017), a respeito dos mundos de ficção, afirma:

Isso significa que os mundos ficcionais são parasitas do mundo real. Não existe nenhuma regra relativa ao número de elementos ficcionais aceitáveis em uma obra. E, como efeito, aqui há uma enorme variedade - formas como a fábula, por exemplo, a todo instante nos levam a aceitar correções em nosso conhecimento do mundo real. No entanto, devemos entender que tudo aquilo que o texto não diferencia explicitamente do que existe no mundo real corresponde às leis e condições do mundo real (ECO, 2017, p. 89)

A partir deste princípio, esta pesquisa propõe considerar que as estratégias observadas neste capítulo são utilizadas, por diversos grupos dentro do fandom dos respectivos jogos, com o objetivo de desenvolver sememas, que permanecem vinculados aos tecnoletos propostos pelo universo fantástico do jogo, que carreguem suas opções ideológicas.

O objetivo é que, através da repetição destes sememas feitos pelos fãs, eles recebam um efeito de sentido de sanção e, permitam a este mesmo grupo que crie discursos sobre suas ideologias sem que possam ser impedidos ou descreditados.

Observando o caso mencionado acima, referente à personagem D.Va, os valores do comportamento tóxico atribuído a $\mathrm{D} . \mathrm{Va}$ (gremlin) permanecem associados à persistência e heroísmo da personagem $D . V a$ (overwatch), pois ambas as representações são associadas constantemente no espaço de fórum. O efeito de sentido de sanção promovido pela repetição acaba por validar os discursos possíveis a partir do semema que compõe $\mathrm{D}$.Va (gremlin). Vejamos no exemplo abaixo, retirado do site Imgur:

Figura 77 - Thread no site Imgur.

200 A partir dos princípios propostos mais acima, definir o personagem Zenyatta, de Overwatch, como “ômnico" seria utilizar tal palavra como um virtuema, dentro do semema/lexema Zenyatta. 


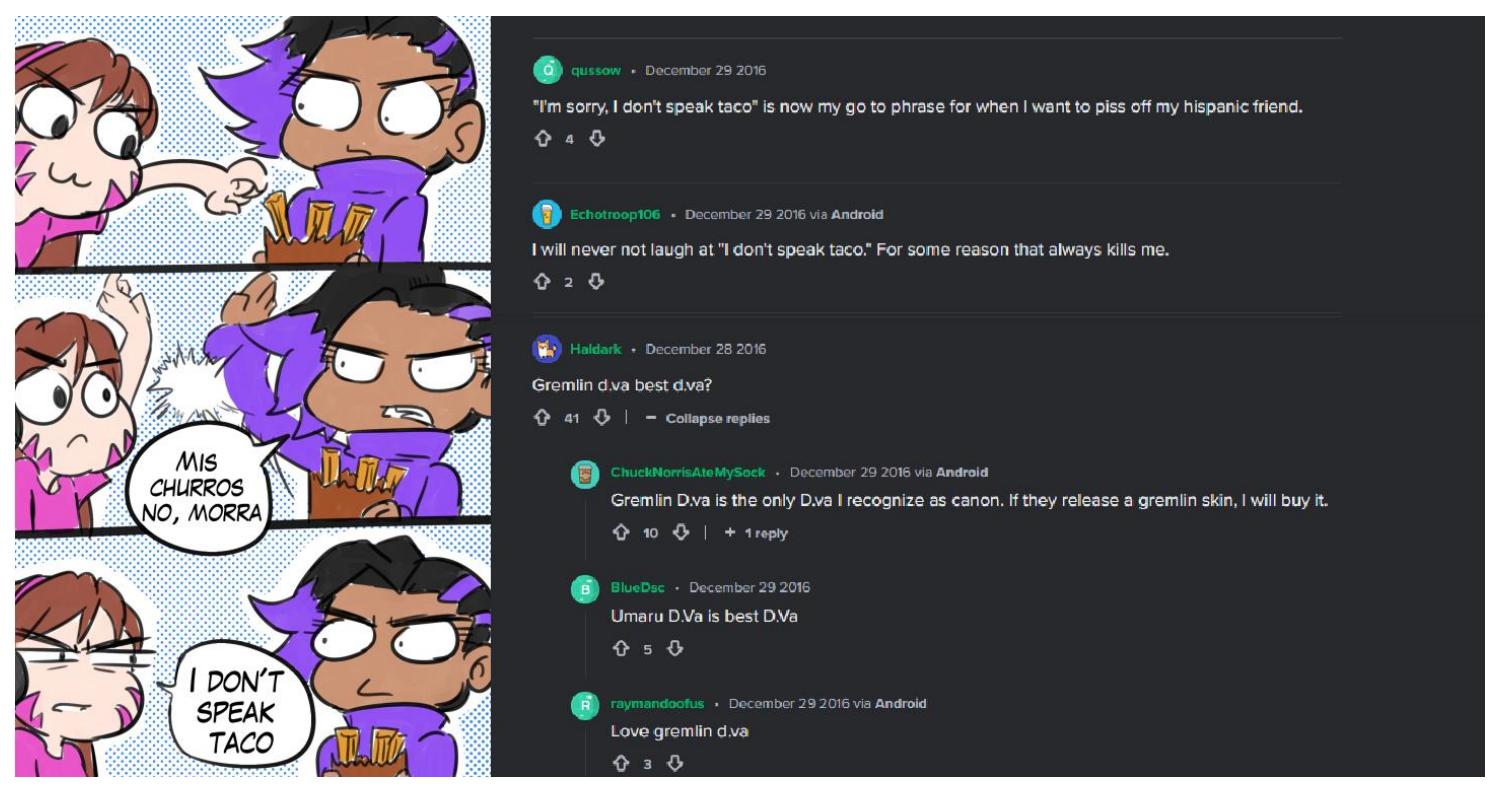

Fonte: Imgur $(2021)^{201}$.

No quadrinho à esquerda, a personagem D.Va tenta pegar os churros da personagem Sombra, que é mexicana. Sombra a impede dizendo "Meus churros não, morra!" em espanhol, ao qual D.Va responde "Eu não falo Taco", maneira pejorativa de se referir a comentários em espanhol na internet.

Nos comentários sobre essa imagem, à direita, o perfil qussow diz “'desculpe, eu não falo taco’ é agora minha frase padrão quando eu quiser irritar meu amigo hispânico". O usuário Echotroop106 diz "Eu nunca não irei rir de 'eu não falo taco'. Por alguma razão isso sempre me mata de rir". Mais abaixo os perfis Haldark, ChuckNorrisAteMySock, BlueDsc e raymandoofus elogiam a personagem D.Va em sua forma sêmica gremlin, dizendo "Gremlin D.Va é a melhor D.Va?" "Gremlin D.Va é a única D.Va que reconheço como canon. Se eles lançarem uma skin gremlin, eu irei comprá-la", "Umaru D.Va é a melhor D.Va" e "Amo a gremlin D.Va", respectivamente.

A xenofobia a minorias, dentre elas os hispânicos, é um elemento criticado a respeito da toxicidade dos gamers na internet. Através de uma construção semêmica que se apoia nas informações canônicas do jogo, este comportamento pode ser apresentado como irreverente e 
inofensivo. E o efeito de verdade que a repetição em fórum de discursos com a $\mathrm{D}$.Va (gremlin) propicia, encoraja os perfis supracitados a manifestar aprovação a este comportamento.

Outro exemplo das estratégias aqui apontadas, de manipulação dos semas, sememas e virtuemas dentro dos tecnoletos presentes no universo dos jogos pode ser visto no caso da campeã Seraphine, de $L O L$.

Em 29 de outubro de 2020, a campeã Seraphine foi lançada em LOL após uma campanha de marketing que envolvia a criação de perfis em redes sociais como Twitter, Instagram e Soundcloud ${ }^{202}$, que simulavam a personagem como uma cantora e compositora independente. A referida campanha de marketing teve duração entre julho e outubro de 2020, e imediatamente após o fim da campanha, era visível que uma vocal parcela do fandom de $L O L$ criticava a adição da personagem ao jogo, sendo o fato noticiado à época 203204.

Os discursos de tais fãs partiam de dois pontos: o primeiro diz respeito à história de Seraphine, de acordo com a pseudociência do universo de $L O L^{205}$ : Seraphine e sua família mudaram de Zaun para Pitlover (respectivamente as cidades de temática Distópica e Steampunk, como discutido no item 2.6.3 desta pesquisa) em busca de melhores condições de vida. Seraphine é uma empata capaz de ouvir a "música interior" das pessoas, e a incapacidade de ignorar a pluralidade de "músicas interiores" da metrópole de Pitlover ameaçava enlouquecê-la. Para salvar a filha, os pais de Seraphine compraram um cristal Brackern, e construíram fones Hextec que isolariam a capacidade empata da filha. O cristal acabou por ensinar Seraphine a controlar sua habilidade, e se

202 SERA DOT WAV. Série de Hiperlinks. LinkTree. Disponível em: 〈https://linktr.ee/seradotwav>. Acesso em: 31 jan. 2021.

${ }^{203}$ DODLEK, Tamara. LoL: The Hate Is Real - Why Does Everyone Hates Seraphine? Early Game. 30 oct. 2020. Disponível em: <https://www.earlygame.com/LOL/LOL-hate-is-real-why-does-everyone-hate-seraphine/>. Acesso em 31 jan. 2021.

${ }^{204}$ HIGGINS, Chris. Why does Half of the internet hate Seraphine, the new LoL champ? HyperX Gaming. 03 nov. 2020. Disponível em: <https://ag.hyperxgaming.com/article/11116/why-does-half-the-internet-hate-seraphine-thenew-LOL-champ>. Acesso em: 31 jan. 2021.

205 LEAGUE OF LEGENDS WIKI. Seraphine (League of Legends). Fandom. Disponível em: <https:// leagueoflegends.fandom.com/wiki/Seraphine>. Acesso em: 31 jan. 2021. 
tornar uma cantora que fazia shows entre Pitlover e Zaun, buscando unir os povos através de sua música.

Dentro da pseudociência do universo de LOL, Hextec ${ }^{206}$ é uma tecnologia avançada, que se baseia em máquinas que são alimentadas por cristais, sendo os melhores destes cristais chamados Brackern $^{207}$. Estes, por sua vez, são considerados uma espécie consciente, com uma mente compartilhada entre todos os seus membros e que pode viver por milênios, grande parte deste tempo em hibernação coletiva. O núcleo destes Brackerns por sua vez é o que gera energia para a tecnologia Hextec, e a voz que Seraphine ouve em seus fones é um exemplar desta inteligência coletiva dos Brackerns. Há inclusive um campeão em $L O L$, Skarner ${ }^{208}$, lançado anos antes de Seraphine (Agosto de 2011), que é um Brackern que busca resgatar os núcleos de sua espécie que são usados como fonte de energia, bem como impedir que novos exemplares sejam roubados durante suas hibernações.

A partir desta criação de lexemas particulares aos tecnoletos do fórum (forma científica), dentro dos parâmetros da pseudociência de $L O L$, sistema jogo-fórum oferece diversos caminhos narrativos incompletos, com investimentos sêmicos (forma semiótica) variados, graças ao método de leitura ergódica do fórum. O fandom então busca que um semema específico (forma códica) se sobreponha sobre os demais, através do efeito de sentido de sanção propiciado pelas estratégias de repetição, observadas na análise sintáxica do nível discursivo.

Para exemplificar melhor tal dinâmica, observemos a análise sêmica de três sememas específicos, recorrentes durante as abordagens do lexema Seraphine no fórum de $L O L$ :

Figura 78 - Análise Sêmica de Seraphine (LOL).

\footnotetext{
206 LEAGUE OF LEGENDS WIKI. Hextech. Fandom. Disponível em: <https://leagueoflegends.fandom.com /wiki/Hextech>. Acesso em: 31 jan. 2021.

207 LEAGUE OF LEGENDS WIKI. Brackern. Fandom. Disponível em: <https://leagueoflegends.fandom.com /wiki/Brackern>. Acesso em: 31 jan. 2021

${ }^{208}$ LEAGUE OF LEGENDS WIKI. Skarner (League of Legends). Fandom. Disponível em: <https://leagueoflegends .fandom.com/wiki/Skarner>. Acesso em: 31 jan. 2021
} 


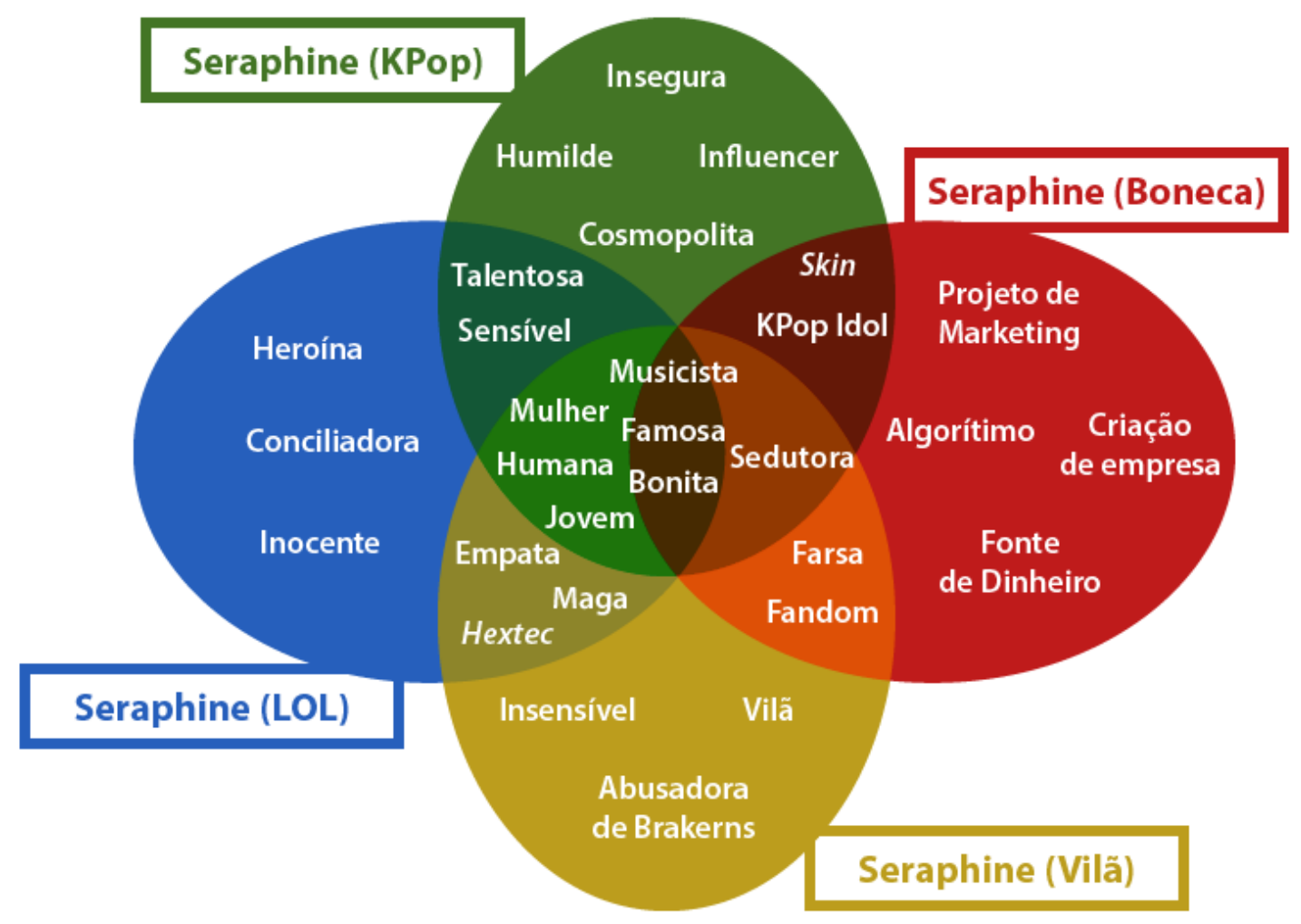

Fonte: imagem nossa.

$\mathrm{Na}$ análise sêmica apresentada acima, foram propostos 4 sememas a respeito do lexema Seraphine:

- $\quad$ Seraphine $(L O L):$ A campeã de $L O L$, de função Mago e Suporte, que habita entre Zaun e Pitlover, e que busca unir as duas cidades através da música. É constituída pelas informações fornecidas pela desenvolvedora do jogo.

- $\quad$ Seraphine (Vilã): A campeã de $L O L$, de função Mago e Suporte, que habita entre Zaun e Pitlover, e que abusa de uma raça de criaturas milenares (Brackerns) para satisfazer as ambições pessoais, se utilizando do poder deles para se firmar como uma estrela. É constituída pelas informações fornecidas pela desenvolvedora do jogo, e devidamente manipuladas pelo fandom. 
- $\quad$ Seraphine (KPop $\left.{ }^{209}\right)$ : Uma skin da personagem de $L O L$ e lançada através de uma ação de marketing em mídias sociais, coabita no mesmo universo paralelo onde existe a banda KDA, formada por outras 4 campeãs de $L O L$. Uma talentosa musicista, de temperamento caridoso e sensível, ainda que insegura, que realiza o sonho do estrelato ao fazer uma parceria com KDA para o lançamento de um single. É constituída pelas informações fornecidas pela desenvolvedora do jogo, e devidamente manipuladas pelo fandom.

- $\quad$ Seraphine (Boneca): Uma skin da personagem de $L O L$ e lançada através de uma ação de marketing em mídias sociais, é a tentativa mais extrema da empresa Blizzard de ganhar dinheiro fácil em cima dos fãs, criando uma personagem fraca, apenas para atrair fãs de KPop com o lançamento de novas músicas e manipulação de tendências nas redes sociais. É constituída pelas informações fornecidas pela desenvolvedora do jogo, e devidamente manipuladas pelo fandom.

Como observado por Greimas e Courtés (2008), as relações entre os semas mais recorrentes nos quatro sememas analisados são psicologizadas e desiguais, porém esta é exatamente a importância desta análise, pois apresenta as estratégias de manipulação dos valores por parte da comunidade em busca da eficácia na manipulação memética.

O semema Seraphine (vilã) se estrutura em uma proposta de sanção narrativa, a partir de uma leitura das estruturas da forma científica do universo de $L O L$. A existência dos Brackerns no universo ficcional e sua possível denominação como um ser vivo, usado como fonte de energia, invalidaria a proposta de atribuir à Seraphine $(L O L)$ semas tímicos de valor eufórico como "inocente" e "conciliadora".

O semema Seraphine (boneca), por sua vez, usa as estruturas da forma científica do jogo, em que se define uma skin como unidade nomeável, para criticar o abuso da utilização das skins te temática KPop do universo KDA (forma semiótica do universo de $L O L$ ) na atração de jogadores

\footnotetext{
${ }^{209}$ Abreviação do termo Korean Pop, gênero musical coreano que possui bastante sucesso no ocidente.
} 
(forma semiótica do jogo), resultando em uma personagem que possui pouca integração com o universo principal de $L O L$ (forma códica do universo de $L O L$ ).

Ambos os raciocínios partem de conjuntos de valores que não são equivalentes, e em alguns casos fazem com que o próprio semema possua conflitos internos. Ainda assim, ambos os sememas estão presentes na última postagem do Twitter de Seraphine, feito pela empresa Blizzard, como parte de sua campanha de lançamento ${ }^{210}$. Dentre os comentários feitos na última postagem do Twitter, após o lançamento de Seraphine no jogo, seguem abaixo alguns exemplares:

Figura 79 - Postagem no Twitter da personagem Seraphine.

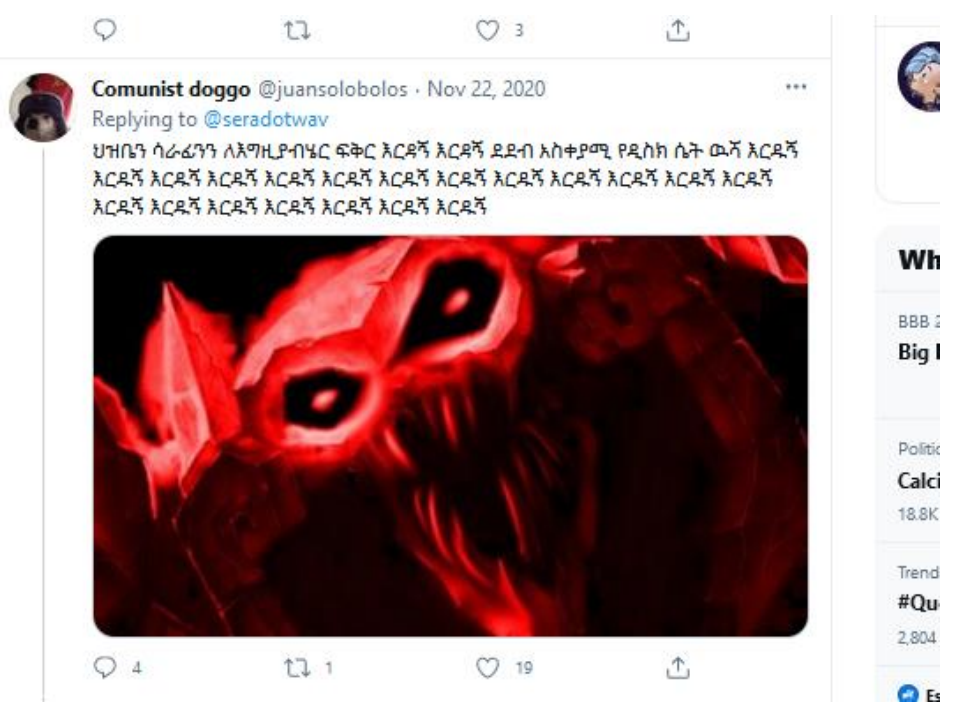

Fonte: Twitter $(2021)^{211}$.

A imagem acima foi postada 15 vezes na thread do último post do twitter de Seraphine, todas por perfis diferentes. A imagem mostra o campeão Skarner, um Brackern, com uma mensagem codificada solicitando "Justiça para Skarner". Este tipo de postagem deslegitima a proposta de sanção no twitter de Seraphine, mobilizando os semas do semema Seraphine (vilã), enquanto se vale da estratégia de repetição, apontada nos itens anteriores.

210 SERA DOT WAV. Perfil de Twitter. Twitter. Disponível em: <https://twitter.com/seradotwav/status/ $1325274845458935809>$. Acesso em 02 fev. 2021.

${ }^{211}$ Disponível em: <https://twitter.com/seradotwav/status/1325274845458935809>. Acesso em: 10 mar. 2021. 
A seguir, outros exemplos retirados da mesma thread de mensagens:

Figura 80 - Postagem no Twitter da personagem Seraphine.

Ricky@Rikyeul · Nov 8, 2020

Replying to @seradotwav and @JumaraloHexCore

Please dont leave, you can stay with us and keep using the social media. :'(

Q 1

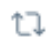

$\bigcirc_{3}$

Migraineismeltingmybrain @Migraineismelt · Nov 18, 2020

Dude, thats a company pretending to be an indie girl.

七】

○ 6

Fonte: Twitter $(2021)^{212}$.

Figura 81 - Postagem no Twitter da personagem Seraphine.

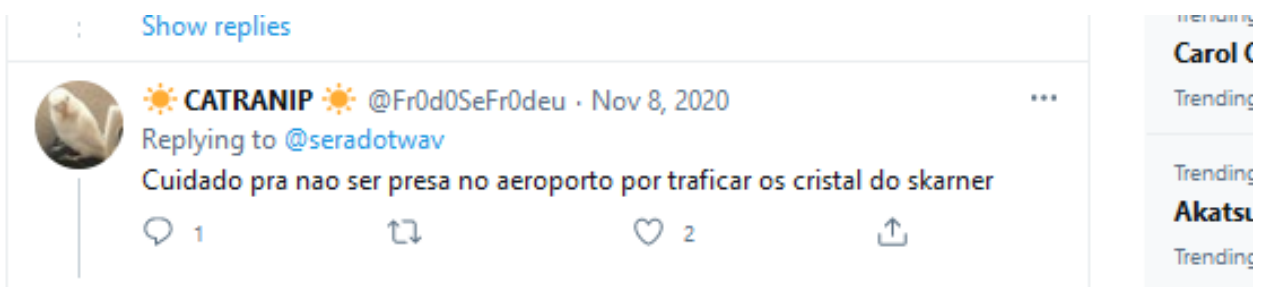

Fonte: Twitter $(2021)^{213}$.

Na primeira imagem, o perfil Ricky lamenta o anúncio do fim das postagens no Twitter de Seraphine, enquanto o perfil Migraineismeltingmybrain responde "Cara, isso é só uma empresa fingindo ser uma menina indie", invocando o semema Seraphine (Boneca). Na segunda imagem, o perfil CATRANIP comenta "Cuidado pra não ser presa no aeroporto por traficar os cristais do Skarner", se referindo aqui ao semema Seraphine (Vilã).

Os sememas invocados pelos perfis nesta thread não operam nos mesmos modelos de linguagem, pois o semema Seraphine (Boneca) se refere ao modelo de linguagem do jogo, enquanto o semema Seraphine (Vilã) opera no modelo de linguagem do universo pseudocientífico

212 Disponível em: <https://twitter.com/seradotwav/status/1325274845458935809>. Acesso em: 10 mar. 2021.

${ }^{213}$ Disponível em: <https://twitter.com/seradotwav/status/1325274845458935809>. Acesso em: 10 mar. 2021. 
de $L O L$. Porém, ainda assim, os perfis podem usar estrategicamente ambos os sememas para se reforçarem discursivamente.

Segundo a análise sêmica do lexema Seraphine, ambos os sememas compartilham os semas de "fraude" (Seraphine [Vilã] é uma "falsa-boa-moça" no universo do jogo, enquanto Seraphine [Boneca] é uma jogada de marketing na forma de uma "falsa-hipster"). Ambos os sememas também reforçam o sema de "fandom" (em que se apresentam como uma ação da comunidade de fãs contra decisões ruins da empresa Blizzard).

A partir destas observações, esta pesquisa propõe que a manipulação dos sememas, mesmo que possuam semas opostos ou não operem no mesmos modelos de linguagem, possibilita estratégias de confronto ou reforço de certos semas, sempre pautados pela repetição e pela interrupção de processos de sanção.

Uma última estratégia de manipulação no domínio sêmico do nível discursivo se refere ao uso de metáforas. Segundo o Dicionário de Semiótica "Atualmente, esse termo é empregado em semântica lexical ou frasal para denominar o resultado da substituição - operada sobre um fundo de equivalência semântica -, num contexto dado, de um lexema por outro" (GREIMAS \& COURTÉS, 2008, p. 305).

Toda a metáfora, a princípio, é um lexema comum, com possíveis sememas e núcleos: Quando dois sememas de lexemas diferentes possuem pelo menos um sema em comum, abre-se a possibilidade da concretização de uma metáfora; sendo que seu potencial metafórico só se mostra no ato da transferência, no lugar de outro lexema.

Tal qual o estabelecimento de um semema num discurso, a metáfora, ainda que carregue consigo uma virtualidade de leituras, depende dos desdobramentos do percurso gerativo de sentido para que uma (ou mais) destas leituras se concretize no texto, através do percurso gerativo de sentido.

Como observado nos itens 2.6.1 a 2.6.3, a necessidade de um elenco de personagens equilibrado, permitindo que todos possam assumir o papel de sujeito de uma narrativa. Este princípio torna necessário que o universo do jogo manipule uma grande quantidade de lexemas e 
tecnoletos, e consequentemente uma grande quantidade de metáforas e pluri-isotopias, muitas vezes conflitantes.

Segue abaixo uma sequência de comentários em relação a personagem Seraphine, no site Reddit:

Figura 82 - Sequência de comentários do site Reddit.

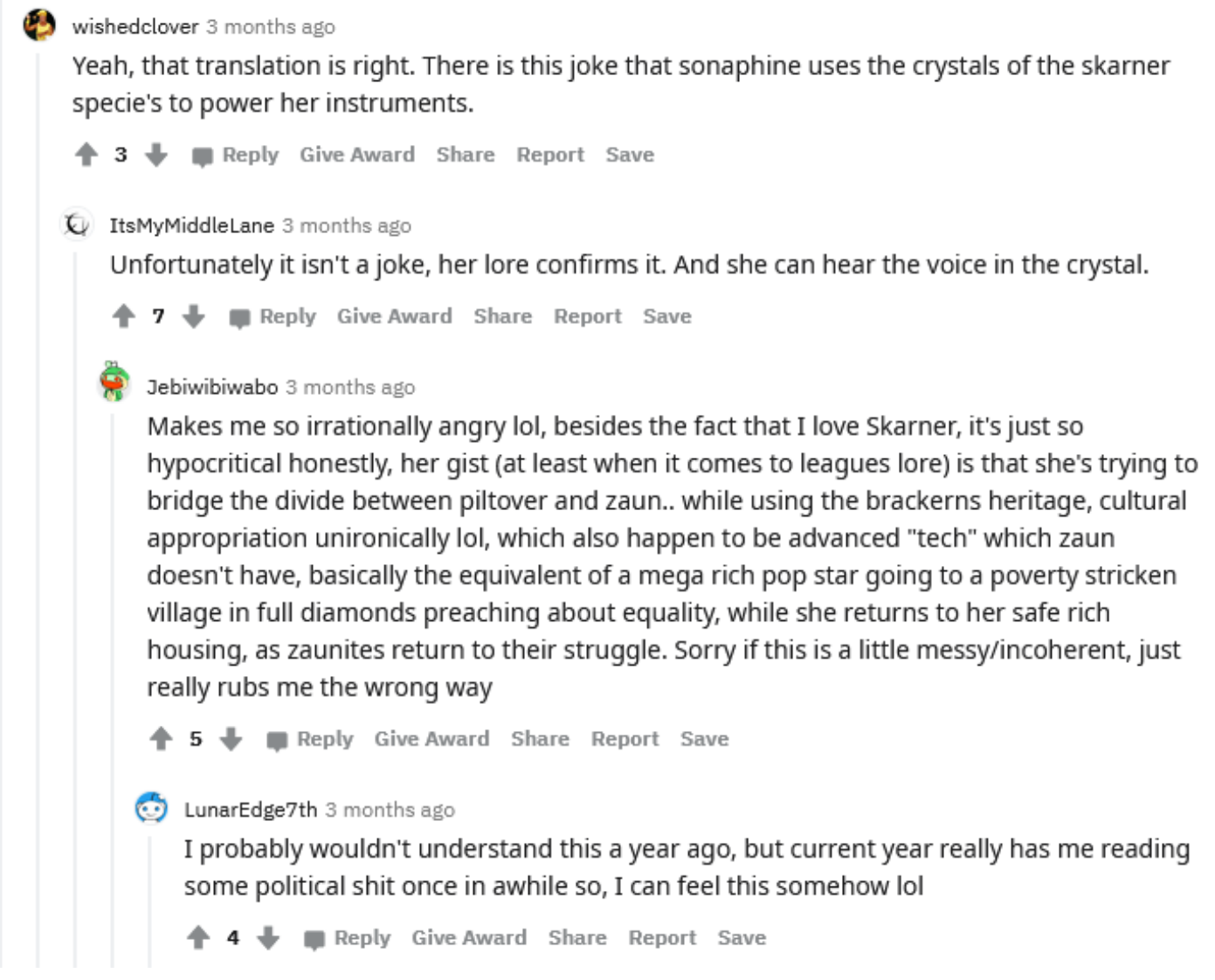

Fonte: Reddit $(2021)^{214}$.

Na postagem acima, 4 perfis comentam sobre um meme, onde fotografias de caçadores tem o rosto substituído pelo rosto da personagem Seraphine.

214 Disponível em: <https://www.reddit.com/r/SkarnerMains/comments/j9zmo6/i_cant_read_this_but_theres_a_ funny_meme_going/>. Acesso em: 10 mar. 2021. 
O primeiro perfil, wishedclover, diz (tradução nossa) "Sim, a tradução está certa. Tem uma piada em que Sonaphine ${ }^{215}$ usa um cristal da espécie de Skarner para alimentar seus instrumentos". O perfil seguinte, ItsMyMiddleLane, corrige "Infelizmente isso não é uma piada, a história dela confirma isso. E ela consegue ouvir a voz do cristal".

Em seguida, o perfil Jebwibiwabo faz uma longa postagem (tradução nossa):

Isso me deixa tão irracionalmente bravo hehe, pois além do fato de eu amar o Skarner, isso é muito hipócrita. Todo o mote dela (ao menos ao que diz respeito ao universo de LOL) é que ela está tentando diminuir as barreiras entre Pitlover e Zaun... enquanto usa a herança Brackern, apropriação cultural, sem ironias aqui hehe, e além de tudo, através da tecnologia avançada que Zaun não possui. É basicamente o equivalente da estrela Pop rica indo a um vilarejo miserável, cheia de diamantes, pregando igualdade: enquanto ela retorna pra casa sua casa rica e segura, os zaunitas voltam para seu sofrimento. Me desculpem se esse texto foi bagunçado/incoerente, é que isso me incomoda bastante.

A seguir, o perfil LunarEdge complementa: "Eu provavelmente não entenderia isso há um ano atrás, mas este ano me fez começar a ler sobre política e outras coisas de vez em quando, e eu consigo entender isso." (tradução nossa).

A leitura de que Seraphine usa um núcleo da espécie de Skarner é declarada no textocontexto do jogo, tal qual a desigualdade social entre Zaun e Pitlover. A leitura de Seraphine como uma celebridade que usa causas sociais para autopromoção é possível, do ponto de vista dos semas e sememas analisados, pois está virtualizado nas narrativas de Seraphine, Skarner e Zaun/Pitlover. Porém, o desenvolvimento destas metáforas toma certas liberdades com o texto.

A natureza dos sentimentos de Seraphine sobre Zaun, ou mesmo o conhecimento de Seraphine sobre a origem de seu cristal ou os detalhes de sua relação com essa "voz" dos Brackerns não é desenvolvida. Sua suposta insensibilidade sobre tal situação é muito mais um sema do trope da "Diva insensível" do que algo que seja reconhecível em Seraphine, pois ambos os lexemas compartilham semas como "celebridade".

\footnotetext{
215 Sonaphine é uma gíria, que mistura o nome de 2 campeãs de $L O L$ : Sona e Seraphine. Esta palavra costuma ser usada para afirmar que a campeã Seraphine (lançada em 2020) é uma cópia da personagem Sona (lançada em 2010). A thread analisada é a de fãs do personagem Skarner, portanto certo antagonismo torna-se previsível.
} 
Quando esta metáfora é desenvolvida, pelo perfil LunarEdge, novos semas são propostos (ainda que de maneira oblíqua), como a ligação dos eventos sociais de 2020 com a postura de Seraphine proposta pelo perfil Jebwibiwabo, configurando uma pluri-isotopia. Tanto o uso das metáforas quanto a construção dos sememas possíveis dos tecnoletos, observados neste item, dependem desta disputa sêmicas e de um certo deslocamento de sentido.

A funcionalidade desta estratégia pode ser desenvolvida, se observarmos a discussão proposta por Umberto Eco em Os limites da interpretação (2000). Neste livro, o autor postula sobre os extremos epistemológicos da interpretação: um extremo é o sentido como "verdade do mundo", um discurso que se aproxima da pansignificação proposta por Todorov (2017). No outro extremo, o autor fala sobre a semiose hermética, descrito como "a habilidade incontrolada de deslizar de significado para significado, de semelhança para semelhança, de uma conexão para outra" (ECO, 2000, p. 279). O autor retomaria este pensamento em outras obras (2018).

Dentro desta semiose hermética, Eco propõe, sob o nome de deriva hermética, baseando sua explicação nos trabalhos sobre a cadeia de "semelhanças de família", do filósofo Renford Bambrough:

Figura 83 - Ilustração de Deriva Hermética.
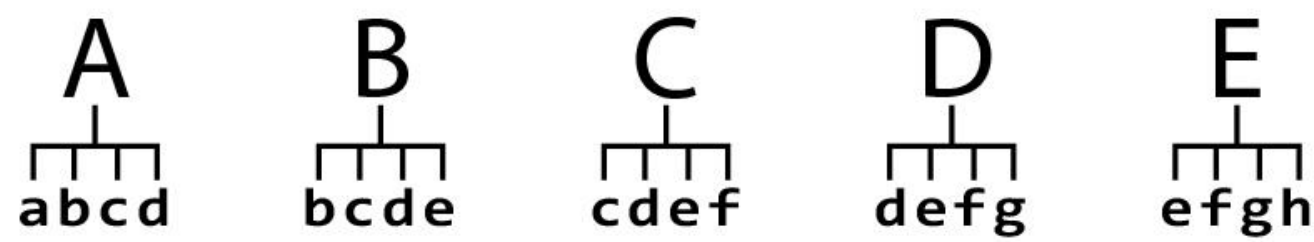

Fonte: imagem nossa, adaptada de Eco (2000)

Segundo Eco, a deriva hermética explica como duas coisas sem nada em comum podem se relacionar por uma cadeia de relações:

No final, não existe qualquer propriedade comum que una $\mathrm{A}$ e E salvo aquela de pertencer à mesma rede de semelhança de família. Numa cadeia desse tipo, no momento em que chegarmos ao conhecimento de $\mathrm{E}$, toda a noção referente a $\mathrm{A}$ terá desaparecido. As conotações proliferam de modo canceroso [...] pois o prazer da deriva está inteiro no deslizamento de um signo para o outro, e nela não existe outro escopo senão o prazer mesmo dessa viagem labiríntica por entre os signos ou as coisas. (ECO, 2000, p. 282). 
Umberto Eco se baseia muito mais no referencial da semiótica Peirceana do que no modelo Greimasiano, porém, o raciocínio pode ser transplantado para o objeto de estudo desta pesquisa com as devidas considerações.

A deriva hermética é aqui considerada como uma estratégia de utilização dos sememas e metáforas dentro da semântica discursiva em fórum. Enquanto Eco argumenta que o prazer da deriva está na deriva em si, no caso dos fóruns, este movimento de deslizar entre sememas e metáforas busca trazer ao centro do percurso gerativo as figuras e semas adequados à defesa de certas ideologias. Quando a temática e os sememas usados se mostram adequados a certas axiologias, a estratégia (observada na análise das táticas de sintaxe) de repetição ad nauseam, promove maior cristalização das figuras e sememas propostos.

Neste sentido, as movimentações observadas anteriormente sobre a rejeição à Seraphine, em que se apontavam estratégias de marketing lado-a-lado a uma interpretação alternativa da narrativa da personagem, se mostram como estratégias. Mobilizam-se sememas e metáforas com semas e virtuemas em comum, que orbitem ao redor dos valores disfóricos da falsidade e hipocrisia ${ }^{216}$, e então repete-se tal estratégia de vinculação em todas as instâncias que citarem o lexema Seraphine, nos diversos fóruns. Quando os demais fãs encontram repetidas vezes tais relações, mesmo que percorrendo diferentes caminhos ergódicos de leitura, cria-se o efeito de sentido de sanção, e convenciona-se que "O fandom odeia Seraphine"217.

Nos textos de estrutura mais tradicional, como livros lineares ou pinturas, existem elementos que costumam invalidar derivas herméticas infinitas, que acabem por correlacionar elementos apenas pelo critério de semelhança familiar. Umberto Eco, a este respeito, aponta que "A semiose é virtualmente ilimitada mas nossos escopos cognitivos organizam, emolduram e

${ }^{216}$ Não estará no escopo desta pesquisa compreender quais são as axiologias buscadas durante estas estratégias dentro dos jogos que compõe o corpus da; mas, vale a pena observar que, na maioria dos casos, os valores refletem os princípios da manifestação cultural dominante: desgosto pela cultura musical coreana, incômodo com o protagonismo feminino na narrativa de inclusão social tradicionalmente vinculada à ideologia da esquerda política, ou outros tipos de ideologias similares.

217 QIANA REEVES. Comentários de Rioters sobre o hate na Seraphine. Riot. 13 out. 2020. Disponível em: $<$ https://forums.comunidades.riotgames.com/t5/Outros-Assuntos-de-LOL/Coment\%C3\%A1rio-de-Rioters-sobre-ohate-na-Seraphine/td-p/935976>. Acesso em: 04 fev. 2021. 
reduzem essa série indeterminada e infinita de possibilidades [...] só nos interessa saber o que é relevante em função de um determinado universo do discurso" (ECO, 2000, p. 281).

Este universo do discurso determinado é garantido pelo percurso gerativo de sentido; o processo de sanção define quais os percursos validados e quais permanecerão virtualizados, bem como as metáforas e pluri-isotopias que de fato estão presentes no texto. Entretanto, como observado anteriormente, a ausência da sanção narrativa no universo do jogo, bem como as estratégias usadas em fórum para desautorizar sanções, diminuem a eficácia desta salvaguarda.

Outros elementos também acabam por permitir uma maior utilização da deriva hermética: a dificuldade de observar tal deriva, enquanto processo, dentro de um sistema de hipertextos; a multiplicidade de linguagens dentro do fórum - linguagem do fórum, linguagem do jogo e linguagem da pseudociência da fantasia -, bem como a possibilidade dos fãs de interferirem nos níveis científicos, semióticos e códigos da linguagem. Por último, é importante observar que os deslizamentos da deriva hermética, e mesmo seu uso excessivo, é fruto de enunciadores coletivos, pois ainda que cada postagem possa ser considerada, por si só, um texto, a maior parte das figuras e temas se estruturam no texto-thread ou no texto-fórum.

Após analisar a sintaxe e semântica do nível discursivo dentro do espaço de fórum, a presente pesquisa agora procede a analisar o tema da veridicção.

\subsection{Veridicção via Graus de Concessão}

A veridicção, segundo definição do Dicionário de Semiótica, é um “dizer-verdadeiro [...] a inscrição (e a leitura) das marcas de veridicção, graças às quais o discurso enunciado se ostenta como verdadeiro ou falso, mentiroso ou secreto" (GREIMAS \& COURTÉS, 2008, p. 530).

Quanto à diferença entre o conceito de verdade e de veridicção, muito já foi discutido sobre a importância de tal separação para o estudo semiótico, e esta pesquisa se contenta em reproduzir a fala de Greimas em Sobre o Sentido II, quando o autor pondera sobre as diversas formas de narrativas existentes (abstratos, figurativos, normativos, descritivo, literários, narrativos, etc.), bem como constata que diversos discursos jurídicos, religiosos e mesmo científicos, deixam-de-ser ou 
passam-a-ser considerados verdade, de acordo com conjunturas sociais de suas épocas. A partir deste pensamento:

Se a verdade é apenas um efeito de sentido, conclui-se que sua produção consiste no exercício de um fazer particular, um fazer-parecer-verdadeiro, isto é, a construção de um discurso cuja função não é o dizer-verdadeiro, mas o parecerverdadeiro. Este parecer não visa mais, como no caso da verossimilhança, à adequação ao referente, mas à adesão por parte do destinatário a quem se dirige, e por que procura ser lido como verdadeiro. Tal adesão, por sua vez, só pode ser obtida se corresponder à sua expectativa; ou seja, a construção do simulacro da verdade é fortemente condicionada não diretamente pelo universo axiológico do destinatário, mas pela representação que dele fizer o destinador, artífice de toda manipulação e responsável pelo sucesso ou fracasso de seu discurso. (GREIMAS, 2014, p. 122)

No livro Sobre o Sentido II (2014), Greimas fala, a respeito da veridiç̧ão, como um “jogo de máscaras":

A sobredeterminação dos actantes segundo a categoria do ser e do parecer explica este extraordinário 'jogo de máscaras' feito de enfrentamentos entre heróis disfarçados, desconhecidos ou reconhecidos e traidores transvestidos, desmascarados ou punidos, o qual constitui um dos eixos essenciais do imaginário narrativo. (GREIMAS, 2014, p. 67)

José Luiz Fiorin, em seu Elementos da Análise do Discurso (2008), retoma a metáfora do jogo de máscaras, mas a vincula à etapa da sanção, em que "ocorre a constatação de que a performance se realizou e, por conseguinte, o reconhecimento do sujeito que operou a transformação" (FIORIN, 2014, p. 31) e afirma ainda que:

A narrativa pode pôr em ação um jogo de máscaras: segredos que devem ser desvelados, mentiras que precisam ser reveladas etc. É na fase da sanção que ocorrem as descobertas e as revelações. É, neste ponto da narrativa, por exemplo, que os falsos heróis são desmascarados e os verdadeiros são reconhecidos (FIORIN, 2014, p. 31)

Vemos aqui, portanto, a relação implícita entre os mecanismos da sanção do nível narrativo com a veridicção do nível discursivo: A sanção narrativa do destinador a respeito do percurso do destinatário capitaneia o caráter eufórico ou disfórico das relações axiológicas da narrativa, bem como cristaliza os respectivos temas e figuras mobilizados. Similarmente, a veridicção é o momento em que o enunciatário avalia o sujeito da enunciação construído pelo enunciador, veridiccionando o discurso dentro do quadrado de veridicção. 
O modelo deste quadrado veridictório, proposto por Greimas, está reproduzido na imagem a seguir, baseado em Beividas (2019):

Figura 84 - Quadrado Veridictório.

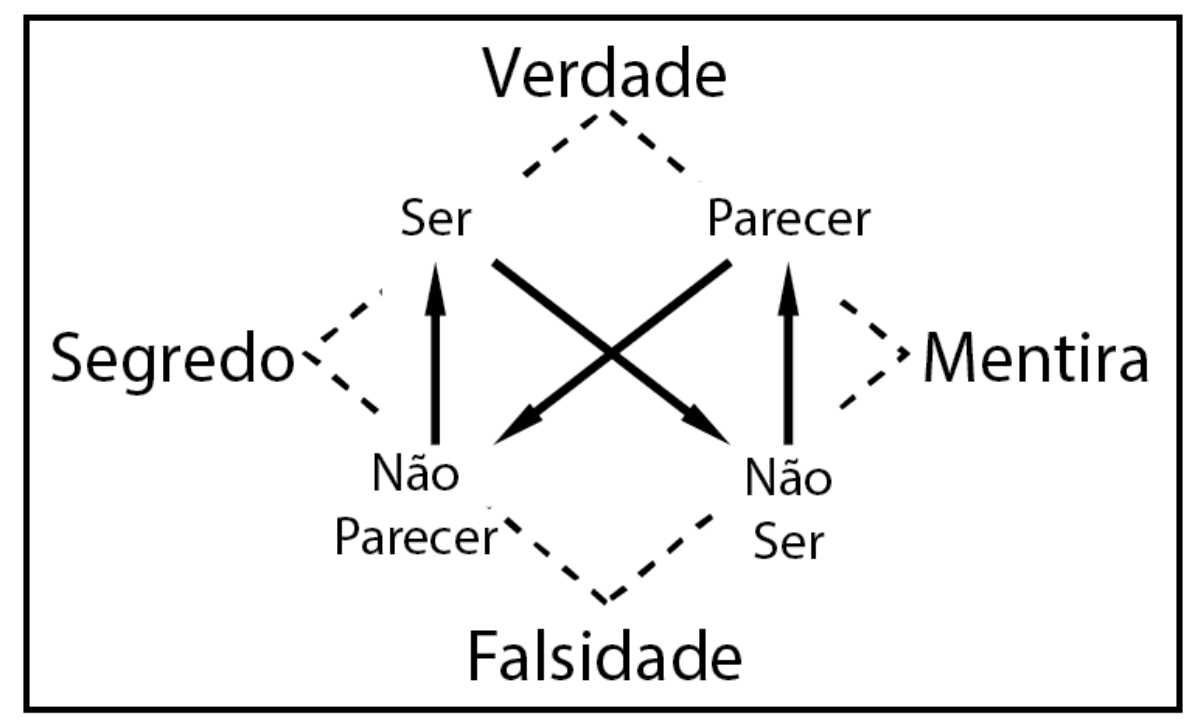

Fonte: imagem nossa, adaptada de Greimas \& Courtés (2008).

Neste quadrado veridictório, são inseridas as categorias do Ser, Não-Ser, Parecer e NãoParecer. Estas quatro categorias são resultado da sobreposição de dois esquemas: o da imanência (ser) e o da manifestação (parecer). Para que os valores de uma narrativa sejam considerados verdadeiros, eles devem parecer verdadeiros dentro do texto (manifestação), e o enunciatário deve vê-los como adequado ao seu conjunto ideológico de valores (imanência).

Entre a manifestação/parecer e a imanência/ser, é proposto que "há uma solicitação do parecer, que o enunciador direciona ao enunciatário, para que ele tome uma decisão do ser" (MANCINI \& LISBOA, 2021, no prelo - tradução dos autores). Ainda que hierarquicamente não haja diferença entre os dois, há uma antecedência sintagmática do parecer em relação ao ser.

Quando a crença em tais discursos e sua aparência coincidem, temos os discursos considerados verdadeiros (é - parece) ou falsos (não é - não parece), em que a oposição polêmica da sanção se encerra e há a aceitação/recusa dos valores propostos pelo destinador/enunciador por parte do destinatário/enunciatário. Sobre a diferença entre crer e saber algo como verdadeiro, Pessoa de Barros afirma: 
Interpretar, para o sujeito, é, por excelência, confrontar a proposta recebida com seu universo do saber e do crer, com os sistemas de valores que atribuem sentido aos fazeres e aos estados. Distinguir a adesão "fiduciária", que envolve sobretudo o crer, da adesão "lógica", que recorre ao saber, é separar tipos de racionalidade, que, no ato de interpretar, se misturam e se confundem na certeza ou na dúvida da verdade, na verdade ou na falsidade da certeza (BARROS, 1988, p. 58)

A intersecção entre essas categorias resulta nas possíveis sanções, mostradas a seguir:

- Verdade: é a intersecção entre o ser e o parecer, quando o discurso é julgado como demonstrando certos valores como verdadeiros, com os quais o enunciatário concorda.

- $\quad$ Falsidade: é a intersecção entre o não-ser e o não-parecer, quando o quando o discurso é julgado como demonstrando certos valores como falsos, com os quais o enunciatário concorda.

- $\quad \underline{S e g r e d o}$ : é a intersecção entre o ser e o não-parecer, quando o quando o discurso é julgado como demonstrando certos valores como falsos, com os quais o enunciatário discorda.

- $\quad$ Mentira: é a intersecção entre o não-ser e o parecer, quando o quando o discurso é julgado como demonstrando certos valores como verdadeiros, com os quais o enunciatário discorda.

Para que tal acordo seja firmado, o enunciador deve produzir um discurso eficaz, através um fazer persuasivo, construindo um ethos e um pathos adequado ao universo de valores de seu enunciatário, bem como o uso de procedimentos discursivos específicos, para que se instale o crerverdadeiro em ambos os lados da comunicação.

Os semioticistas brasileiros Renata Mancini e Vinícius Lisboa, no artigo "Uma leitura tensiva das modalidades veridictórias" (2020), propõe uma abordagem das modalidades veridictórias a partir dos estudos tensivos de Claude Zilberberg. A partir do princípio da proeminência do parecer em relação ao ser, os autores propõem:

Posicionando os dois funtivos de acordo com os modos de existência, de forma a considerar um sujeito que apreende o parecer e o julga, esse é da ordem do atualizado, da apropriação em relação ao repertório virtual para uma percepção 
inicial, que é, então, realizada no ser, com um ponto de vista do sujeito (MANCINI \& LISBOA, 2021, no prelo - tradução dos autores).

A atualização do parecer virtualizado é proposto, então, como uma competência, que portanto é realizada através de um processo: o sujeito-julgador percebe a narrativa virtualizada e disponível para julgamento a partir de seus valores, estes também virtualizados; ele compreende a estrutura como forma atualizada e solicitante de sanção; ele realiza o julgamento, se as virtualidades da narrativa preenchem seus próprios valores virtualizados, e; quando o julgamento do regime veridictório se estabelece, ocorre a potencialização (e retorno à visualização), quando o resultado da veridicção alimenta os valores virtualizados, reforçando-os ou reorganizando-os.

Considerando a existência deste "percurso de veridicção", os autores do artigo então propõem que as quatro categorias veridictórias necessitem de desdobramentos para atender a tal percurso:

Se cada manifestação é uma solicitação ao enunciatário, que tem perfil específico e faz um esforço de apreensão para julgar a imanência, não podemos ampliar para mais que quatro os resultados possíveis desse jogo? Todas as verdades e falsidades são iguais e se confirmam com a mesma exatidão? Todos os segredos e mentiras surpreendem com igual espanto? E se estamos falando de efeitos de sentido diferentes que se constroem na enunciação, como semioticistas, não devemos tentar dar conta de caracterizá-los? (MANCINI \& LISBOA, 2021, no prelo tradução dos autores)

Com este objetivo em mente, os autores estabelecem relações implicativas e concessivas entre as quatro modalidades veridictórias: a Verdade e a Falsidade são modalidades implicativas, pois quando algo parece/não parece, espera-se que ele seja/não seja. Já as modalidades de Mentira e Segredo são concessivas, pois a mudança de expectativa causa um aumento de intensidade, obrigando-o a relocalizar seus valores e modalizações.

A partir da necessidade de representar tais diferentes intensidades em cada percurso veridictório, Mancini e Lisboa propõe o seguinte gráfico:

Figura 85 - Modelo veridictório tensivo 


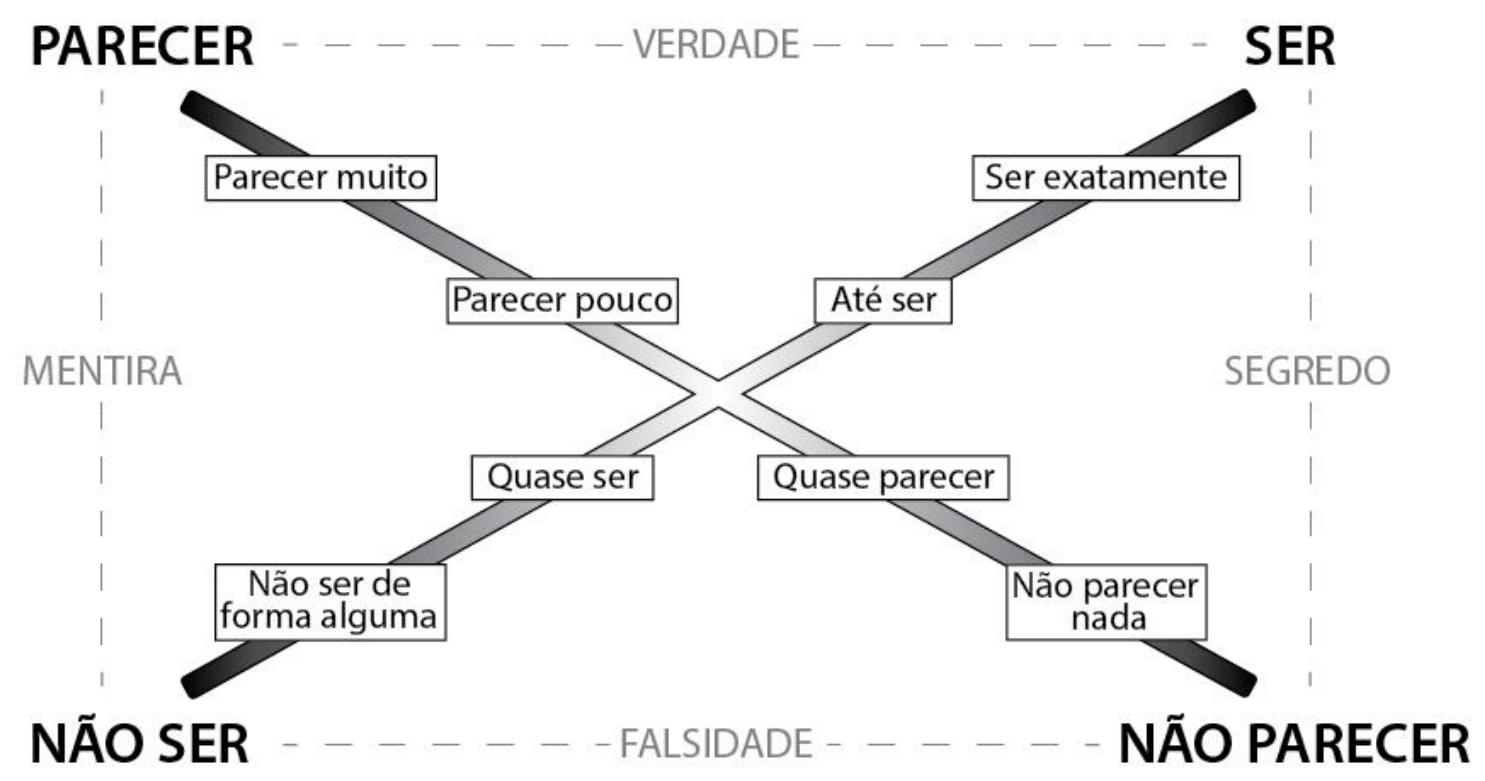

Fonte: imagem nossa, adaptada de Mancini \& Lisboa (2021).

A partir do modelo apresentado, o processo de veridicção passa a levar em consideração a experiência sensível do enunciatário, bem como o esforço empreendido pelo enunciador na construção do discurso. Quanto maior a intensidade do Ser/Não Ser/Parecer/Não Parecer, representados no modelo acima como as pontas do " $\mathrm{X}$ " central, maior aderência e inerência entre o sujeito (enunciatário) e objeto (discurso). Nestes casos, o sujeito se vê penetrado pelo sentido do objeto. Quanto menor a intensidade, menos a aderência/imanência, levando ao simples reconhecimento do objeto.

Os autores observam ainda que a mentira e o segredo, por serem mais impactantes ao sujeito, possuem perfis iconoclastas:

O segredo e a mentira, ao contradizerem as capacidades do sujeito, essas baseadas nos valores virtualizados, potencializam novos valores na práxis enunciativa. Enquanto a outra dupla confirma e fortalece os valores vigentes, essa os desloca, os enfraquece e os põem em xeque. Uma sucessiva revelação de segredos sobre algo sólido é capaz de fazê-lo derreter? Uma sequência de desmentidas sobre um dogma pode derrubá-lo do pedestal? Quantos e de que ordem tensiva deveriam ser esses acontecimentos? São perguntas que podem nortear novas reflexões sobre as surpresas por trás das veridicções que põem em conflito o ser e o parecer (MANCINI \& LISBOA, 2021, no prelo - tradução dos autores). 
Esta pesquisa pretende utilizar o modelo veridictório tensivo proposto por Mancini \& Lisboa, por crer que a estrutura de gradiente é adequada para observar a interação em fóruns online, do ponto de vista macrotextual ${ }^{218}$, que inclui os fóruns e os jogos analisados nesta pesquisa.

Inicialmente, é importante apontar que, dada a natureza dos jogos do corpus, analisados no capítulo 2, o universo ficcional destes é altamente metafórico e pluri-isotópico, pois tentam compreender em si uma metáfora do mundo e suas diferenças, desigualdade e pluralidade. Esta alta densidade metafórica é reforçada pela estratégia, das empresas produtoras dos jogos, do uso da incompletude narrativa como efeito de sentido, como proposto por Razzino Ernica (2014), que mantém a euforização ou disforização dos temas e figuras no campo do virtualizado.

Estas estratégias permitem que, quando um enunciatário, membro da comunidade, entre no fórum, encontre alguns discursos pontuais que mobilizem tal pletora de pluri-isotopias, metáforas, semas, sememas e virtuemas numa configuração específica, extremamente adequada aos seus valores. E graças à possibilidade de participação no continuum memético como co-enunciador (Spaziante [2007] e Marino [2018]), assim como em threads, através de comentários que constantemente atualizam o texto (Discini [2015]), este enunciatário pode anexar ao macrotexto fórum sua leitura extremamente adequada a seus valores. Temos então, dentro do gradiente ser/não ser, a alta aderência e inerência características do sujeito penetrado por um discurso, na ordem do "ser exatamente" e "não ser de forma alguma".

Porém, os textos do espaço de fórum, além de solicitarem a interpretação, como dizem Mancini \& Lisboa, solicitam também a intervenção dos enunciatários. Assim como tal enunciador hipotético pode interferir no macrotexto coletivo do fórum, outros co-enunciadores, que possuem valores ideológicos divergentes ou opostos, podem usar da mesma estratégia. Em cada novo processo de leitura ergódica, costuma ser improvável que nosso enunciatário hipotético não se depare com intervenções de co-enunciadores, propondo veridicções diferentes.

${ }^{218}$ Macrotexto será a definição usada por esta pesquisa para se referir a textos que sejam produzidos por mais de um enunciador, como threads em fóruns, conjuntos de threads, ou postagens que se refiram a decisões dos desenvolvedores dos jogos. Descrito em detalhes no glossário no fim da dissertação. 
Como foi observado anteriormente por Jamison (2017) e Jenkins (1992), sobre as dinâmicas dos fãs (item 4.2.2), o fandom tem uma característica de enfrentamento constante. Disputas entre facções de fãs a respeito de interpretações sobre o universo ficcional não são incomuns (como esta pesquisa observou ao estudar os casos de D.Va, Soldado 76 e Seraphine), e mesmo quando existe uma facção estável dentro do fandom, não é incomum que surjam divisões dentro deles.

A partir da premissa que as veridicções da verdade e da falsidade são implicativas pois surpreendem pouco, e as veridicções do segredo e da mentira surpreendem muito, pois são concessivas, aliada à predisposição combativa dentro dos fandons, levam à uma preeminência da presença da mentira e do segredo nos espaços de fórum. Para um impacto maior dentro do sistema de valores propostos pelos macrotextos do fórum, ao invés dos co-enunciadores intervirem, reforçando veridicções como verdades ou falsidades, estes enunciatários assumem o papel de coenunciadores, muitas vezes, para propor veridicções dos textos em fórum como segredos e mentiras.

Porém, do ponto de vista do macrotexto, diversas variáveis interferem nesta dinâmica:

- A natureza dos perfis de fórum como enunciadores pouco confiáveis, abordado no item 3.3 desta pesquisa;

- A constante atualização do jogo, na condição de texto-base;

- As ambiguidades promovidas pelo humor e pelo uso extenso de pressupostos, abordados no item 4.2 desta pesquisa e;

- A necessidade de que, devido à pouca influência de perfis individuais, estratégias conjuntas de veridicção tenham que ser utilizadas, levando a alianças e oposições pontuais entre grupos do fandom, com o objetivo de promover repetições o suficiente para cristalizar o continuum memético e também criar o efeito de sentido de sanção discursiva.

O efeito da manifestação (parecer) do discurso proposto acaba se tornando confuso e conflitante, levando a um tipo de veridicção de baixa aderência e inerência, do tipo "quase parecer" ou "parecer pouco". Na imagem a seguir, as duas condições propostas acima estão marcadas em vermelho: 
Figura 86 - Modelo veridictório tensivo aplicado ao objeto de pesquisa.

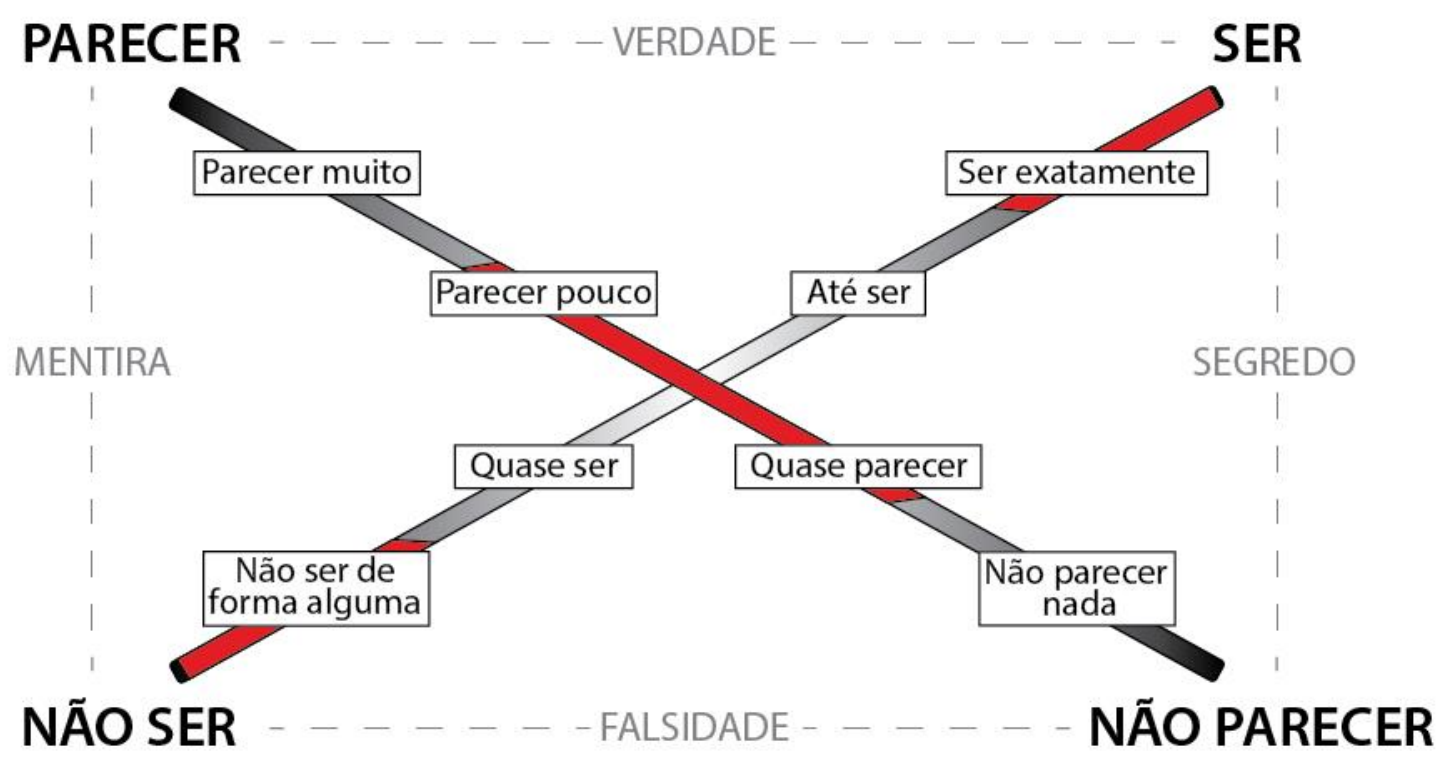

Fonte: imagem nossa, adaptada de Mancini \& Lisboa (2021).

Algumas considerações devem ser feitas a respeito desta proposta. Inicialmente, os próprios autores do modelo veridictório tensivo admitem que "a ideia deste trabalho não é propor um número fixo de possibilidades, e sim uma formulação que contenha um intervalo entre elas, mediado por graus, pelo acréscimo e subtração de mais e menos que permite casas decimais infinitas entre os números que parecem inteiros" (MANCINI \& LISBOA, 2021, no prelo - tradução dos autores).

De acordo com esta expectativa, esta pesquisa também não pretende estabelecer graus fixos em sua afirmação, mas ao invés disso apontar uma tendência: geralmente, as veridicções em espaço de fórum são regidas, em sua maioria, pelos regimes do segredo e da mentira, com o gradiente da manifestação sendo manifestado com menor aderência e imanência (menos intenso), enquanto o gradiente da imanência é manifestado com maior aderência e imanência (mais intenso).

Outra observação necessária se deve ao alcance desta afirmação. Esta análise é feita a partir de macrotextos do espaço de fórum, não podendo ser estendida a outras configurações discursivas do espaço de fórum. Grupos de textos menores ou mesmo individuais, como a interação em fórum entre apenas dois perfis, ou comentários analisados individualmente, tenderão a não seguir a leitura 
acima proposta, pois tanto a construção do texto como o perfil dos enunciadores e enunciatários envolvidos serão diferentes.

Quanto à sequência sintagmática da veridicção, que vai do parecer ao ser, esta pesquisa propõe a seguinte leitura:

- O discurso construído pelo enunciador coletivo está fundado em um universo altamente metafórico, e em um percurso narrativo que não possui sanção, onde, portanto, permanecem virtualizadas diversas possibilidades axiológicas e tímicas;

- Como observado no item 4.2 desta pesquisa, a maioria das tentativas de sanção, via comentários, praticadas no fórum, costuma ser posta em xeque, através de estratégias como a recorrência a um destinador transcendente, o uso de pressupostos ou a manipulação ad nauseam de sememas do discurso;

- A cada atualização do macrotexto, as veridicções de segredo e mentira se repetem, pois num discurso de enunciador e enunciatário coletivos, as veridicções de mentira e segredo causam mais impacto e, portanto, são mais eficazes em reorganizar as figuras, temas e sememas em circulação;

- Devido ao impasse veridictório, diante das constantes sobreposições de segredos e mentiras, as repetições em fórum, as alianças e oposições temporárias entre ideologias em prol de estratégias maiores, e as cristalizações do continuum memético acabam por gerar um efeito de sentido de sanção, que ainda que não encerre o discurso, serve como convenção de sanção dentro do fandom;

- Tal efeito de sentido de sanção se apresenta como um parecer (manifestação) pouco aderente e pouco inerente, em função da pluralidade de leituras virtualizadas e das constantes atualizações;

- Porém, o ser (imanência) interpretado pelos enunciatários é de alta aderência e imanência, pois, apesar dos conflitos textuais dentro do macrotexto, a ação do enunciatário é sustentada por um discurso “ideal”, do qual é possível encontrar ecos em outros discursos ou mesmo nas virtualizações incompletas. Este discurso ideal é, 
em última instância, o discurso que o próprio enunciatário, na condição de coenunciador propõe, e tenta manter vivo e reprodutível dentro do macrotexto;

- É característica do discurso de internet que, a não ser que um discurso se propague, ele desaparece (Jenkins, Green \& Ford, 2014). Portanto a imanência intensa sobre uma manifestação pouco intensa, que se apresenta nos segredos e mentiras do macrotexto do fórum, busca manter fragmentos dispersos do discurso que é o "ideal" para o enunciatário, para que este possa continuar empreendendo a busca de promover sua própria versão.

Após o levantamento da dinâmica veridictória dos fóruns, dentro do corpus e escopo propostos por esta pesquisa, o último ponto a ser abordado é a observação de como este tipo de discurso se apresenta em relação a outros discursos que circulam no mesmo espaço.

\subsubsection{Discurso mentiroso, discurso poético, discurso fantasioso e discurso conspiratório}

Durante os últimos anos, a semioticista Diana Pessoa de Barros tem promovido estudos sobre as Fake News do ponto de vista da semiótica. Numa de suas mais recentes publicações, o artigo intitulado "As Fake News e as 'anomalias"” (2020), a autora descreve, em relação ao processo veridictório que permite que se acredite em uma Fake News:

Quando a interpretação se baseia, sobretudo ou apenas, nas crenças e emoções do destinatário interpretante, os discursos mentirosos são entendidos como verdadeiros. Em outras palavras, por mais absurdos que pareçam, os discursos cujos valores estão de acordo com as crenças e sentimentos do destinatário são por ele considerados verdadeiros. É o chamado viés de confirmação, tendência de as pessoas acreditarem nas informações que apoiam suas visões e valores, e desconsiderarem as que dizem o contrário (BARROS, 2020, p. 28).

O raciocínio do viés de confirmação proposto por Pessoa de Barros guarda similaridades com a dinâmica veridictória apontada no item anterior. Porém, enquanto no caso das Fake News, o enunciatário ignora elementos conflitantes de um discurso, que poderia ser considerado mentiroso, em nome de um crer intenso, no modelo proposto por esta pesquisa, o enunciatário busca uma sanção conflituosa em relação à manifestação, para garantir a sobrevivência das 
virtualidades do seu discurso ideal (que, para fins de comparação, é análogo ao "crer intenso" observado nas Fake News).

Devido ao potencial danoso que as Fake News possuem, pois tentam criar desinformação, manipulando o discurso e as crenças do enunciatário, Pessoa de Barros sugere enumerar quais as características principais desse tipo de discurso, para então propor estratégias de combate a ele. As estratégias fundamentais das Fake News, de acordo com a autora são:

- Escalonamento: $\mathrm{O}$ destinador/enunciador cria um vínculo com o seu destinatário/enunciatário divulgando, inicialmente, notícias comprovadamente verdadeiras, e que ajudem a alinhar emocional e ideologicamente enunciador e enunciatário. Quando tal vínculo se cristaliza, o destinador começa a inserir notícias falsas, que manipulem os mesmos elementos emocionais e ideológicos que o vinculam ao enunciatário, para que este se veja predisposto a se valer do viés de confirmação em seu processo de veridicção do discurso.

- $\quad$ Ancoragem: O destinador/enunciador se utiliza de uma figurativização (atores, lugares e datas) conhecida do destinatário/enunciatário, para reforçar o efeito de realidade e, ao mesmo tempo, se valer desta figurativização para criar o efeito do argumento de autoridade, já que uma afirmação atribuída a uma figura conhecida, e devidamente capacidade, suscita menos dúvidas em relação à mesma afirmação, pronunciada por um locutor desconhecido.

- $\quad$ Emprego de pessoa: O emprego da primeira e segunda pessoa em Fake News é utilizado para produzir um efeito de proximidade e cumplicidade "entre o destinador, que viu, viveu e sentiu o que está contando, e o destinatário” (BARROS, 2020, p. 29). O emprego da terceira pessoa, por sua vez, reforça o efeito de isenção do enunciador, bem como pode reforçar a figurativização da autoridade, descrita no item anterior.

Levantadas as características mais marcantes dos discursos de Fake News, a autora propõe estratégias de análise e, consequentemente, desmonte deste tipo de discurso.

A análise dos diálogos que a possível Fake News mantém com outros textos. A retomada dos textos-contextos é importante pois "Os sentidos de um texto se constroem dialogicamente, ou 
seja, pelas relações com outros textos. No caso das notícias falsas, os diálogos apontam incoerências e contradições entre essas vozes" (BARROS, 2020, p. 31). Comparação com textos e atores citados, bem como textos que versem sobre o mesmo universo figurativo, são exemplos de análise dialógica.

Outra estratégia proposta pela autora é a análise da organização discursiva e textual da possível Fake News:

Em outras palavras, se o texto for mal elaborado, usar estratégias inadequadas, organizar-se de forma contraditória, não seguir o padrão do gênero ou o estilo de língua apropriado, apresentar problemas de argumentação e de concordância semântica, ele poderá ser "desmascarado" com base nos "desvios" e "erros" de sua composição interna ou de seu estilo e valores. (BARROS, 2020, p. 34).

Definidos os modos de analisar e desmascarar as Fake News, Pessoa de Barros propõe então o entendimento destes elementos como um tipo específico de discurso (o discurso das Fake News), que seria reconhecível pelas estratégias que utiliza. "Temos insistido que estas interpretações se fazem com base no projeto enunciativo, e veridictório, do enunciador e nos conhecimentos, crenças e emoções do enunciatário que interpreta" (BARROS, 2020, p. 37).

Para nomear este "tipo de discurso", a autora propõe o termo projeto enunciativo ${ }^{219}$, a partir da acepção proposta por Renata Mancini, em seu artigo “A tradução enquanto processo":

Entendemos por projeto enunciativo o conjunto de estratégias de textualização postas em prática no ato de criação que dão corpo ao projeto de persuasão de um enunciador (o perfil discursivo de quem "diz") em relação ao fazer interpretativo do perfil específico de enunciatário visado (perfil discursivo do leitor, espectador, ouvinte etc.). Vale reforçar que o fazer interpretativo contempla também os modos de engajamento sensível, para além dos elementos de construção da intangibilidade (MANCINI, 2020, p. 26).

Este projeto enunciativo, dentro dos moldes propostos por Mancini, se constrói a partir da manipulação de três eixos principais:

219 Projeto Enunciativo é o conjunto de estratégias discursivas que visam atingir um determinado efeito sobre o enunciatário de um discurso. Descrito em detalhes no glossário no fim da dissertação. 
- $\quad$ Foco narrativo: Hierarquizando os programas narrativos e organizando as narrativas que apresentam o conteúdo do texto;

- Dinâmica de perspectivas: estratégias de localização pessoal/espacial/temporal do discurso, e;

- Direcionamento ideológico/axiológico: As escolhas semânticas e sintáxicas, de temas e figuras.

A identificação dos aumentos e diminuições de intensidade provocados pelo projeto enunciativo constrói o que Mancini nomeia Arco Tensivo. Em seus estudos, voltados para tradução, este arco pode ser definido como "o desenho da interface sensível de uma obra, um perfil que se constrói a partir da alternância entre momentos de impacto (mais fortes e mais tênues) e momentos mais brandos (em graus de atonia), isto é, entre saliências (acentos) e "passâncias" (inacentos)" (MANCINI, 2020, p. 25). O arco tensivo é, portanto, a identificação dos aumentos e diminuições de intensidade no decorrer da narrativa. A intenção e estratégias utilizadas para gerar este tipo de arco tensivo, é o projeto enunciativo, e, por fim, a recorrência de um projeto enunciativo (como é o caso das Fake News) se apresenta como um tipo de discurso.

No caso do "discurso de Fake News" observado por Pessoa de Barros, estas "constroem seu arco tensivo a partir de cifras tensivas de impacto, definidas pelas saliências ou acentos que procuramos apontar nas estratégias de construção desse tipo de texto, e produzem com isso maior engajamento de seu destinatário" (BARROS, 2020, p. 38).

A partir dos estudos de Mancini e Pessoa de Barros, esta pesquisa encerrará sua análise propondo um esboço, usando das noções de arco tensivo e projeto enunciativo, de um dos tipos de discurso recorrentes nos fóruns, cujos elementos principais foram levantados no decorrer desta 
dissertação, e propõe-se chamar de "discurso conspiratório online" 220 . Os principais elementos estratégicos deste tipo de discurso podem ser numerados como:

- $\quad$ Figura de universalidade: Inicialmente, sobre as ideologias que circulam no discurso conspiratório online, estas podem ser diversas, mas se constroem sobre uma mesma estrutura. Tal discurso se constrói dentro de um universo ficcional complexo, altamente metalinguístico, pois sua estética de incompletude permite que as figuras e metáforas de narrativas opostas permaneçam virtualizadas dentro dele. Este universo se torna denso ao ponto de precisar de uma pseudociência própria para dar conta do volume de significados. O usuário do discurso conspiratório online se vale deste universo, que se encontra num ponto de equilíbrio entre a forma finita e o conteúdo infinito.

Ao falar sobre o escudo forjado por Hefesto para Aquiles, durante a guerra de Tróia narrada em Ilíada, Homero descreve uma paisagem detalhada e rica, que se estende temporalmente e é cercada pelo oceano. No livro A vertigem das Listas (2010), Umberto Eco analisa esta passagem, sobre esta vastidão de detalhes comprimida dentro da forma fechada do escudo, e afirma que:

Do ponto de vista referencial, uma colocação em forma não nos encoraja a ver outras coisas além das que ela representa. O escudo de Aquiles nos fala apenas daquele território citadino e campestre e não daquilo que existe além do círculo do Oceano. Isso não exclui este território como um modelo universal da cidade ou aquelas imagens como uma alegoria de bom governo, da guerra, da paz ou da condição natural. Mas a forma limita o universo do "dito" (ECO, 2010, p. 12).

Portanto este universo ficcional se vale de metáforas e tropes da cultura da internet (a manifestação cultural dominante) para suscitar figuras que representem as

${ }^{220}$ A nomenclatura "conspiratório online" proposta se justifica em função das particularidades do ambiente digital: teorias conspiratórias e comportamentos conspiratórios existem desde muito antes da internet, sendo sido objeto de estudo de ECO (2000), e possuindo alguns de seus exemplos mais famosos relacionados a períodos anteriores à internet (os conspiratórios sobre alienígenas e sociedades secretas já eram conhecidos do senso comum desde a primeira metade do século XX, se pegarmos como exemplo os efeitos de "Guerra dos Mundos"[1938] e "Protocolos dos Sábios de Sião" [1920]). Esta pesquisa se limita, ao nomear tal tipo de discurso como "conspiratório online", a observar tais discursos conspiratórios que dependem do suporte dos fóruns e da internet, separando-se assim de um hipotético "discurso conspiratório offline", que, enquanto certamente guardará semelhanças com o discurso conspiratório online analisado, possuirá também diferenças de forma e conteúdo. 
culturas humanas e sua variedade e divergências, de modo que, formalmente, propõe um universo fechado e global, onde qualquer resposta sobre o mundo pode ser encontrada.

Ao mesmo tempo, como foi discutido na escolha do termo "elenco" (item 2.5.3) para nomear os campeões e agentes de cada jogo, este universo possui uma lista de termos-chave não-exaustiva, e desenvolvida, de acordo com a necessidade de tal universo formal fechado, de acolher novas metáforas e figuras dentro de sua totalidade universal de sentido.

Cada novo personagem criado nos jogos é uma porta de entrada para novas pluriisotopias que ainda não estavam presente neste universo discursivo, mas são apresentadas e figurativizadas como se já estivessem virtualizadas dentro deste universo pleno de sentido.

- Domínio do tecnoleto: Este universo, rico em metáforas e uma linguagem pseudocientífica própria, acaba por se espalhar na linguagem científica, semiótica e códica (Beividas, 2015) dos discursos que se referem a tal universo. O indivíduo que se utiliza do discurso conspiratório online domina a manipulação do tecnoleto deste universo, em todos os seus níveis de linguagem.

Possuindo este amplo conhecimento da construção semântica de cada palavra, circulante nos discursos, este indivíduo constrói e interpreta os textos do fórum manipulando cada léxico particular do tecnoleto, propondo sememas específicos, com um conjunto de semas que se mostre eficaz na criação e sustentação de certas figuras e metáforas, úteis aos valores ideológicos deste enunciador.

Para além de saber construir e manipular tal semântica, o usuário do discurso conspiratório online se engaja em movimentos pontuais em que rechaça ou apoia certos sememas, pois vê neles os semas e valores que interessam a seu discurso ideológico.

- Segredos e Mentiras: Devido às movimentações estratégicas do enunciador/ sancionador, que se vale do discurso conspiratório online na construção dos temas e 
figuras, este tem por estratégia a predileção de sanções do tipo do Segredo e da Mentira.

Este enunciador/enunciatário preferirá buscar, dentro do macrotexto do fórum, discursos com valores opostos aos dele, para exercer as sanções do segredo e da mentira. Mesmo quando estiver sancionando um discurso como verdadeiro ou falso, ele irá lançar mão de temas, debreagens e narrativas disfóricas que coloquem discursos divergentes na chave do segredo (como, ao dizer que um discurso é verdadeiro, argumentar que algum tipo de hegemonia oprime tal discurso, e ele se apresentaria, portanto, como secreto) e da mentira (ao dizer que um discurso é verdadeiro, irá evocar discursos e valores divergentes, presentes em outros discursos, para então apresentá-los como mentira). É, aliás, a busca pelo segredo e pela mentira, que está por trás das estratégias de ataque ao discurso de autoridade, uso do destinador transcendente, e abuso dos pressupostos.

Esta estratégia possui dois principais pontos úteis ao enunciador/enunciatário do discurso conspiratório online: a primeira é que, devido à quebra de expectativa entre o parecer e o ser, presente na veridicção da mentira e do segredo, este tipo de sanção veridictória salta mais aos olhos dos outros fãs/enunciatários do fórum, do que uma sanção de verdade/falsidade.

O outro efeito é de que, devido ao aumento da intensidade, após uma sanção veridictória concessiva do tipo do segredo ou da mentira (Mancini \& Lisboa, 2021 no prelo), figuras e temas acabam sofrendo uma revisão, após a quebra da expectativa. Esta revisão é o terreno ideal para o enunciador do discurso conspiratório online pôr em prática seu conhecimento do tecnoleto vigente, e cristalizar certos sememas lexicais, em benefício próprio.

Pessoa de Barros (2020) já observou anteriormente que tanto o discurso das Fake News quanto o discurso poético operam dentro do regime da mentira e do segredo, respectivamente. $\mathrm{O}$ discurso da conspiração online se vale de ambos em suas estratégias. 
- $\quad$ Comportamento Saturante: O usuário do discurso conspiratório online, em concordância com o elemento fanático da cultura dos fãs, se comporta de maneira excessiva e saturante. Após mergulhar no universo fantasioso complexo, manipular e pluralizar os significados dos tecnoletos lexicais, e entrar em combate com autoridades e sanções divergentes, sobrepondo-as com suas próprias ideologias, este co-enunciador e membro do enunciatário coletivo se vê dentro de um ambiente intenso e conflitante.

Ainda que, na maioria dos casos, tais enunciadores/enunciatários não tenham consciência dos mecanismos da disciplina semiótica, eles sabem da importância da repetição dentro do espaço de fórum. O enunciador conspiratório online, se engaja então nas práticas de repetição, produzindo seus discursos e suas veridicções em várias threads dentro do macrotexto do fórum; bem como replicando e comentando qualquer comentário de ideologia divergente.

Tais enunciadores também produzem e compartilham discursos em diversas linguagens, bem como tomam parte em movimentos como tornar certas hashtags as mais citadas num site, ou ainda a postagem, de diversos perfis, de um mesmo discurso, como forma de protesto ou intervenção.

Com esta estratégia, o enunciador conspiratório online colabora o quanto pode para que os discursos que possuam suas inclinações ideológicas adquiram o status de efeito de sentido de sanção, bem como promove a cristalização, dentro do continuum memético, de certos discursos multi-linguagem, que servem de material para a produção de mais discursos.

Com estes quatro pilares, qual poderia ser pressuposto como o objetivo maior deste discurso conspiratório online? Ainda que seja necessário um aprofundamento maior a respeito dessa proposta, bem como uma definição mais clara dos limites de sua abrangência, alguns encaminhamentos já podem ser propostos por parte desta pesquisa.

O enunciador do discurso conspiratório online, que possui um crer intenso sobre uma verdade que apenas ele (e às vezes um grupo limitado de semelhantes) conhece, usa as estratégias 
apontadas acima para promover argumentos elípticos ${ }^{221} \mathrm{em}$ virtualmente qualquer texto dentro do macrotexto do fórum. Opera sempre para construir sua verdade como se extraísse pepitas do "sentido do mundo" que acredita, que se encontravam virtualizadas dentro de discursos, sejam favoráveis ou contrários. Agindo desta forma, operando de maneira ergódica e caótica dentro do discurso, o enunciador conspiratório online não pode ser sancionado nem desmentido. Consegue assim dizer o que acredita, a todo o momento que quiser e para quem quiser, sem a necessidade (que para ele, é um inconveniente) de realizar a análise intertextual de seus valores, pois manipulará os tecnoletos, as metáforas, as pessoas e os papéis do discurso.

${ }^{221}$ Argumento Elíptico, no contexto desta pesquisa, será considerado um argumento oculto dentro de um discurso, mas do qual pressupõe-se a existência, a partir de sinais dentro da enunciação ou das figuras do discurso. Diferentemente de um subentendido (Ducrot 1987), onde geralmente a etiqueta impede que o enunciador aborde o subentendido diretamente, no caso do argumento elíptico o enunciador mantém tal informação "escondida" dentro do discurso como uma estratégia de construção de sua pseudociência e dos sememas de seu tecnoleto. Já que, na maioria dos casos, o endereçamento a tal argumento elíptico exporia seu caráter meramente fictício e metafórico. 


\section{CONSIDERAÇÕES FINAIS}

No decorrer deste estudo, a presente pesquisa buscou analisar como a manipulação de um universo fantasioso, mas com relações metafóricas com o mundo das coisas, interfere nas estratégias de sanção e veridicção discursivas. Num segundo momento, propôs-se ainda o enquadramento de algumas dessas estratégias, às quais foi dado o nome de "discurso conspiratório online". Nas considerações finais de tal pesquisa, cabem algumas observações mais gerais sobre o que foi discutido.

Primeiramente, é importante apontar que o "discurso conspiratório online” possui uma forma difícil de ser enquadrada com precisão: o comportamento desse discurso não é exclusivo do espaço de fandom e nem pode ser considerado como a única estratégia utilizada pelos fãs em suas manobras discursivas.

Sobre a não-exclusividade do ambiente de fórum, é possível aprofundar um pouco o raciocínio. $\mathrm{Na}$ introdução deste trabalho, foi proposto que a presente pesquisa poderia ajudar a compreender a dinâmica dos QAnon, Negacionistas e seguidores de políticos conspiratórios, porém, para atingir tal intento é necessário delimitar o seu campo de ação. Mais precisamente, é preciso analisar as características da dimensão de fantasia que de fato é observável dentro do discurso.

Pessoa de Barros (2020), ao analisar as Fake News sobre tratamentos alternativos contra o coronavirus, aponta "contradições, incoerências, rupturas e anomalias" (BARROS, 2020, p. 30), que são identificáveis por se referir a uma forma científica aceita e com autoridade estabelecida. Num dos exemplos utilizados, vemos o procedimento de análise:

Um exemplo é o de um vídeo em que Jorge Gustavo, "químico autodidata", afirma, categoricamente, que passar álcool em gel nas mãos não só não é eficaz na prevenção de infecções por vírus e bactérias, como favorece a transmissão de doenças, como a Covid-19, e propõe, em seu lugar, o vinagre, usando argumentos, aparentemente, científicos; quando colocamos esse texto para dialogar com os textos da Química, verificamos que os estudiosos da área desmentem o que nele é dito sobre o álcool gel e afirmam que o vinagre não mata o vírus; a intertextualidade indica que o texto do vídeo não se sustenta na área da Química, pois se contrapõe, com erros técnicos e conceituais e sem apresentar evidências científicas, ao conhecimento científico já adquirido sobre a questão; (BARROS, 2020, p. 31). 
Quando um discurso de forma científica simplória - como as teorias presentes na afirmação do químico autodidata Jorge Gustavo - entra em divergência com a forma científica mais robusta na qual é baseada, a diferença de status de ambas as formas científicas dentro da sociedade acaba por gerar a leitura da falsidade (não parece e não é verdadeiro). Pois:

A "Verdade", para ser dita e assumida, tem de deslocar-se em direção às instâncias do enunciador e do enunciatário. Não mais se imagina que o enunciador produza discursos verdadeiros, mas discursos que produzem um efeito de sentido "verdade": desse ponto de vista, a produção da verdade corresponde ao exercício de um fazer cognitivo particular, de um fazer parecer verdadeiro que se pode chamar, sem nenhuma nuance pejorativa, de fazer persuasivo (GREIMAS \& COURTÉS, 2008, p. 531).

Para persuadir o enunciatário, o enunciador necessita que seu discurso atinja os valores que aquele considera como verdadeiros. O discurso do químico autodidata, analisado por Pessoa de Barros, se apresenta apenas como um "desvio" conveniente do discurso da química: ele dialoga com poucos universos de valores - Veem-se acenos ao discurso meritocrata, e dos valores da tradição, mas nenhuma hipertextualidade real - e, em grande parte, só consegue circular em ambientes que respeitem a autoridade do discurso da química, mas não possuam as competências necessárias para sua manipulação. Tal estrutura permite que o modelo de análise crítica de Pessoa de Barros identifique com facilidade os embustes discursivos.

Para que um discurso seja passível de classificação como “discurso conspiratório online”, além da circulação em fóruns digitais, ele deve se apresentar como uma espécie específica de fantasia, contendo os elementos apontados nesta pesquisa: o efeito de globalidade e de representatividade, os usos intensos da metáfora e da pluri-isotopia, uma pseudociência (forma científica), sememas (forma semiótica) e tecnoletos (forma códica) próprios, a ausência de sanção e recompensas nos diversos embates narrativos.

Como exemplo, podemos observar brevemente um mundo fantasioso que, ocasionalmente, se encontra com os discursos de Fake News analisados por Pessoa de Barros: o discurso da ameaça 
comunista. Nos últimos anos, tanto negacionistas brasileiros ${ }^{222}$ como membros do QAnon $^{223}$ têm se referido à um suposto complô, promovido por organizações e indivíduos vinculados aos valores de uma "esquerda progressista", que pretende destruir as liberdades e valores sociais. Tal construção fantasiosa atende com mais precisão aos elementos propostos pelo modelo do discurso conspiratório digital: a ameaça comunista possui versões particulares em diversos países e grupos sociais $^{224}$, bem como envolve membros de todos os matizes políticos, sociais e culturais ${ }^{225}$, dando o efeito de globalidade e representatividade ao universo fantasioso. Esse discurso conspiratório digital também possui uma forma pseudocientífica, sememas e termos próprios ${ }^{226}$. Por fim, é uma ideologia que propõe a manutenção do conflito, diminuindo sanções (principalmente negativas) e transformando-as em novos conflitos não-sancionados 227.

Assim como apontado anteriormente nesta conclusão, o território fluído por onde circula o discurso conspiratório online faz com que, ao invés da observação apenas do ambiente digital específico ou um grupo que possa se utilizar de tais estratégias, é preciso também observar as características do universo fantasioso ao qual tais discursos se referem. Isso é justificado pois as características da construção da fantasia digital que permeia os discursos conspiratórios online são importantes para a construção da noção de "verdade". Porém, é sempre importante lembrar que não se pode preestabelecer que um tipo de fantasia, mesmo que seguindo aos elementos

222 FERNANDES, Sabrina, PERRUSO, Marco Antonio, KAZ, Roberto. Como surgem as teorias conspiratórias da direita? Carta Capital. 08 jun. 2019. Disponível em: <https://www.cartacapital.com.br/opiniao/como-surgem-asteorias-conspiratorias-da-direita/>. Acesso em: 13 mar. 2021.

${ }^{223}$ WONG, Julia Carrie. QAnon explained: the antisemitic conspiracy theory gaining traction around the world. The Guardian. 25 ago. 2020. Disponível em: <https://www.theguardian.com/us-news/2020/aug/25/qanon-conspiracytheory-explained-trump-what-is >. Acesso em: 13 mar. 2021.

${ }^{224}$ GALLAGHER, Aoife, BOUMA, Rudy. How did the QAnon conspiracy go global? Al Jazeera. 10 fev. 2021. Disponível em <https://www.aljazeera.com/podcasts/2021/2/10/how-did-the-qanon-conspiracy-go-global>. Acesso em: 13 de mar. 2021.

225 GOMES, Wilson. O complô comunista como matriz governamental de Bolsonaro. Revista Cult. 26 jul. 2019. Disponível em <https://revistacult.uol.com.br/home/o-complo-comunista-como-matriz-governamental-de-bolsonaro />. Acesso em: 13 mar. 2021.

${ }^{226}$ REDAÇÃO. Glossário de 'bolsonarês' para entender o novo governo. Revista Veja. 06 jan. 2019. Disponível em: <https://veja.abril.com.br/politica/glossario-de-bolsonares-para-entender-o-novo-governo/>. Acesso em: 13 mar. 2021.

227 TEIXEIRA, Lucas Borges. Com CoronaVac, Bolsonaro pode tirar de Dória protagonismo na vacinação. UOL. 10 jan. 2021. Disponível em: <https://noticias.uol.com.br/saude/ultimas-noticias/redacao/2021/01/10/coronavacprotagonismo-bolsonaro-doria-vacinacao.htm>. Acesso em 13 mar. 2021. 
apresentados nesta pesquisa, não é por si só a responsável pelo discurso conspiratório online. É na intersecção de universo fantasioso, dinâmica de fórum e projeto enunciativo avesso à sanção e a veridicção concessiva, que este discurso floresce de maneira adequada.

Quanto aos ideais envolvidos neste discurso, ainda que seja cedo para afirmar alguma conclusão, dada a necessidade de um aprofundamento da presente pesquisa, é possível propor que o discurso conspiratório online possui elementos fascistas, caso consideremos como referência o Ur-Fascismo proposto por Umberto Eco em O Fascismo Eterno (2018). Em uma conferência proferida em 1995, o autor, ao falar sobre as diversas características heterogêneas e contraditórias que os regimes fascistas demostravam no decorrer do século XX:

O termo "fascismo" adapta-se a tudo porque é possível eliminar de um regime fascista um ou mais aspectos, e ele sempre continuará sempre a ser reconhecido como fascista. Tirem do fascismo o imperialismo e teremos Franco ou Salazar; tirem o colonialismo e teremos o fascismo balcânico. Acrescentem ao fascismo italiano um anticapitalismo radical (que nunca fascinou Mussolini) e teremos Ezra Pound. Acrescentem o culto da mitologia celta e o misticismo do Graal (completamente estranho ao fascismo oficial) e teremos um dos mais respeitados gurus fascistas, Julius Evola. A despeito dessa confusão, considero possível indicar uma lista de características típicas daquilo que eu gostaria de chamar de "Ur-Fascismo", ou "fascismo eterno". Tais características não podem ser reunidas em um sistema; muitas se contradizem entre si e são típicas de outras formas de despotismo ou fanatismo. Mas é suficiente que uma delas se apresente para fazer com que se forme uma nebulosa fascista. (ECO, 2018, p. 42-44).

Tais elementos funcionam, de acordo com o próprio autor, como uma semelhança de família, descrita neste trabalho, no item 4.3.2. E é possível observar que alguns dos 14 pontos levantados por Eco dialogam com algumas das características propostas para o discurso conspiratório online:

- 1: O culto à tradiçãa - Uma espécie específica de sincretismo, que não tolera contradições, e que pressupõe que a verdade já foi descoberta, e todos os desdobramentos do saber devem apenas se referir a essa verdade. "Quem percorre as prateleiras das livrarias americanas que trazem a indicação 'New Age' encontrará até mesmo Santo Agostinho, o qual, que se saiba, não era fascista. Mas o próprio fato de juntar Santo Agostinho e Stonehenge, isto é um sintoma de Ur-Fascismo" (ECO, 2018, p. 46). No corpus desta pesquisa, os valores-base dos universos 
fantasiosos dos jogos são constantemente reafirmados sob novas roupagens, a cada expansão de personagens, através dos efeitos de globalidade e representatividade.

- 3: A ação pela ação - "Pensar é uma forma de castração. Por isso, a cultura é suspeita na medida em que é identificada com atitudes críticas" (ECO, 2018, p. 48). A tendência do discurso conspiratório da internet em buscar a sanção concessiva, bem como a produção ad nauseam de posts, discursos, imagens e memes para a criação do efeito de sentido de sanção, pode ser encarada por essa perspectiva. É importante ressaltar porém que, enquanto o ambiente de fórum, coletivamente, não apresenta tais efeitos, o usuário ou grupo de usuários do discurso conspiratório online se engaja numa incessante manifestação de seus pontos de vista.

- 4: O desacordo é traição - Em busca de solidificar suas visões, sememas e metáforas, não é incomum que os usuários do discurso conspiratório online ataquem divergências dentro dos fóruns, buscando tirar o protagonismo de projetos enunciativos diferentes, e gerando subgrupos antagonistas, como observado por Jamison (2017). Tal qual no item anterior, é importante observar que existe uma diversidade de ideias dentro dos fóruns de fãs pelo simples volume de pessoas, sem o percalço espacial, presentes. Porém o discurso conspiratório online costuma rechaçar tais pluralidades.

- \#7: Obsessão da conspiração - "Para os que se veem privados de qualquer identidade social, o Ur-Fascismo diz que seu único privilégio é o mais comum de todos: ter nascido em um mesmo país [...] Os únicos que podem fornecer uma identidade às nações são os inimigos" (ECO, 2018, p. 50-51). Ainda que as "fronteiras" entre as identidades em fóruns não possuam materialidade geográficas, elas incluem o contexto socioletal da manifestação cultural dominante, e se constroem com valores igualmente sólidos, possuindo inclusive a inclinação a enxergar conspirações por parte de todos que divirjam de seus valores. O uso dos perfis de fórum (item 3.3) e a recorrência ao destinador transcendente (item 4.2.4).

- 8: Os inimigos são, ao mesmo tempo, fortes demais e fracos demais - "Os adeptos [do Ur-Fascismo] devem sentir-se humilhados pela riqueza ostensiva e pela 
força do inimigo [...] precisam, contudo, ser convencidos que podem derrotar o inimigo" (ECO, 2018, p. 51-52). A ambiguidade de avaliação dos opositores foi vista em diversos pontos da pesquisa, porém é possível destacar essa ambiguidade entre o riso bergsoniano (crítico aos inimigos perigosos) e riso bakhtiniano (que traz os inimigos ao "mundo de baixo") no item 4.2.1, e também ao uso do destinador transcendente, em que o opositor é apresentado como uma débil marionete de uma figura superior, esta sempre mais elusiva e perigosa.

- 9: A vida é uma guerra permanente - Na pesquisa apresentada, foi apontada a predileção pela veridicção concessiva da mentira e do segredo, bem como as diversas estratégias de sanção, em especial no capítulo 4, como o uso extensivo de pressupostos, bem como a ausência se subentendidos, disputa das configurações sêmicas do discurso e postagens acusatórias e conspiratórias replicadas ad nauseam. A recorrência desses dispositivos gera um "Complexo de Armagedom: a partir do momento em que os inimigos podem e devem ser derrotados tem que haver uma batalha final, depois da qual o movimento assumirá o controle do mundo" (ECO, 2018, p. 52). Os usuários do discurso conspiratório online tratam cada divergência como uma ameaça a sua interpretação do universo ficcional, portanto uma batalha que precisa ser ganha.

- 11: Cada um é educado para tornar-se um herói - A manutenção dos perfis e dos comentários pelos adeptos do discurso conspiratório online é próxima da necessidade de que "na ideologia Ur-Fascista o heroísmo é a norma” (ECO, 2018, p. 54). Graças ao manto do anonimato promovido pelos perfis de fórum, esses usuários se engajam no comportamento excessivo e combativo abordado nos itens anteriores. Para além da postura combativa, o culto ao heroísmo aparece também na busca dos usuários pelas sanções quantitativas (likes) dos fóruns, que se apresentam como forma de reconhecimento da excepcionalidade heroica dentro do ambiente digital. 
- 14: O Ur-Fascismo fala a "novilíngua ${ }^{228 " ~-~ O r i g i n a l m e n t e, ~ E c o ~ u t i l i z a ~ o ~ t e r m o ~}$ para se referir às manipulações linguísticas promovidas pelo nazismo e o partido fascista italiano, mas aponta que "devemos, porém, estar prontos a identificar outras formas de novilíngua, mesmo quando tomam a forma inocente de um talk show popular" (2018, p. 59). O controle do tecnoleto do universo ficcional, construído desde a forma científica até sua forma códica, por parte dos usuários do discurso conspiratório online, pode ser vista sob esta perspectiva.

Pensando na possibilidade de extensão do uso das propostas aqui arroladas, para além dos fóruns de jogos e na direção de discursos sociopolíticos em outras plataformas digitais, e a suposição de suas relações com o Ur-Fascismo, tal ideia merece algumas ressalvas. A primeira é que tal proposta é inicialmente apenas uma hipótese em fase inicial, ainda necessitando de maiores estudos para poder ser afirmada com propriedade. A segunda ressalva é, novamente, o fator da independência do discurso conspiratório online de seus suportes: essa natureza Ur-Fascista proposta não é intrínseca aos jogos e seus universos de fantasia, nem aos fóruns, nem aos fãs; mas sim ao discurso aqui analisado, que circula entre estes meios (e outros), fazendo uso de suas características para um projeto enunciativo específico.

Uma última observação deve ser feita sobre o discurso conspiratório online. Seus limites e os detalhes de suas características ficam mais claros à medida que se observam suas interações com outros espaços, bem como quando identificam-se a outras formas discursivas. No capítulo 4, a observação do discurso de Fake News de Pessoa de Barros, ajudou a estabelecer diferenças que compõem o próprio discurso conspiratório online. O confrontamento desta proposta com outras correntes semióticas também se faz necessário; um maior aprofundamento dos elementos abordados a partir da semiótica tensiva de Claude Zilberberg, ou a observação das estratégias apontadas dentro dos níveis de pertinência de Jacques Fontanille, cuja a terminologia apresenta semelhança com alguns dos termos aqui propostos.

228 A Novilíngua é o termo usado por George Orwell, para se referir à língua oficial mandatória, proposta ao estado fictício de Oceania pelo Ingsoc, o partido político que controla a região, no livro 1984 (1949). 
Apesar das observações acima, acredita-se que os pontos aqui levantados já apresentam-se como plausíveis hipóteses de partida para aprofundar a literatura a respeito das relações narrativas entre a fantasia e a sociedade, especialmente as relações intermediadas pela interface digital. 


\section{REFERÊNCIAS BIBLIOGRÁFICAS}

AARSETH, Espen J. Cybertext - Perspectives on Ergodic Literature. Maryland : John Hopkins University Press, 1997.

AARSETH, Espen J. Allegories of Space: The question of spaciality in computer games. In: ESKELINEN, M.; KOSKIMAA, R. (org.). Cybertext Yearbook 2000. Jyväskylä. University of Jyväskylä. 2001.p 152-171.

ANGELO, José Romero Cardozo. Análise semiótica de videogames: uma aposta na interdisciplinaridade. 2015. Dissertação (Mestrado em Estudos de Linguagem). Instituto de Letras, UFF, 2015. Disponível em: <https://app.uff.br/riuff/handle/1/11248 >. Acesso em: 11 mar. 2021.

BAKHTIN, Mikhail. A cultura popular na Idade Média e no Renascimento: o contexto de François Rabelais. Tradução: VIEIRA, Yara Frateschi. São Paulo: Editora Hucitec, 1987.

BARBIERI, Daniele. A Linguagem dos Quadrinhos. Tradução: DO AMARAL, Thiago de Almeida Castor. São Paulo: Editora Peirópolis, 2017.

BARROS, Diana Luz Pessoa de. Teoria do Discurso: Fundamentos Semióticos. São Paulo: Atual Editora, 1988.

BARROS, Diana Luz Pessoa de. Teoria Semiótica do Texto. São Paulo: Editora Ática, 2005.

BARROS, Diana Luz Pessoa de. A comunicação humana. In: FIORIN, José Luiz (org.). Introdução à Linguística I: Objetos teóricos. São Paulo: Editora Contexto, 2015a, p. 25-54.

BARROS, Diana Luz Pessoa de. A complexidade discursiva na internet. CASA: Cadernos de Semiótica Aplicada, Araraquara, v. 13, n.2, 2015b, p. 13-31. Disponível em: <https://periodicos. fclar.unesp.br/casa/article/view/8028>. Acesso em: 10 dez. 2020.

BARROS, Diana Luz Pessoa de. As Fake News e as 'anomalias'. VERBUM: Cadernos de pós graduação. São Paulo, v. 9, n. 2, 2020, p. 26-41. Disponível em: <https://revistas.pucsp.br/index.php/verbum/article/view/50523>. Acesso em: 12 jan. 2021.

BARTHES, Roland. A Câmara Clara: notas sobre a fotografia. Tradução: GUIMARÃES, Júlio Castañon. Rio de Janeiro: Nova Fronteira, 2015.

BEIVIDAS, Waldir. Semióticas sincréticas: Posições (a linguagem do cinema). São Paulo: Annablume, 2015.

BEIVIDAS, Waldir. "Teoria Semiótica do Discurso: Tendências Atuais, Pontos Críticos, Conceitos Revisitados"; Disciplina de Pós-Graduação. 20 de março - 02 de julho; São Paulo, Depto. de Linguística, FFLCH-USP, 2019. 
BERGSON, Henry. O Riso: Ensaio sobre o significado do cômico. Tradução: CAPPELLO, Maria Adriana Camargo. São Paulo: Edipro, 2018.

CAILLOIS, Roger. Os Jogos e os Homens: A máscara e a Vertigem. Tradução: PALHA, José Garcez. Lisboa: Edições Cotovia, 1990.

CANCLINI, Néstor Garcia. Diferentes Desiguales y Desconectados: mapas de la interculturalidad. Barcelona: Editorial Gedisa S.A., 2007.

CÂNDIDO, Antônio. A Personagem do Romance. In: CANDIDO, Antônio (et.al.). A Personagem de Ficção. São Paulo: Perspectiva, 2014.

CZIKSENTMIHALYI, Mihaly. Flow: the Psychology of Optimal Experience. Nova York: Harper Collins, 2008.

DAWKINS, Richard. O Gene Egoísta. Tradução: RUBINO, Rejane. São Paulo: Companhia das Letras, 2007.

DE CERTEAU, Michel. A Invenção do Cotidiano: artes do fazer. Tradução: ALVES, Ephraim Ferreira. Petrópolis: Editora Vozes, 1998.

DISCINI, Norma. Blog e campo de presença. CASA: Cadernos de Semiótica Aplicada, v. 13, n. 2, 2015, p. 89-143.

DUCROT, Oswald. O dizer e o dito. Tradução: GUIMARÃES, Eduardo. Campinas: Pontes Editores, 1987.

ECO, Umberto. Os limites da interpretação. Tradução: CARVALHO, Pérola de. São Paulo: Perspectiva, 2000.

ECO, Umberto. A Vertigem das Listas. Tradução: AGUIAR, Eliana. Rio de Janeiro: Editora Record, 2010.

ECO, Umberto. Tratado geral de semiótica. Tradução: DANESI, Antonio de Pádua, DE SOUZA, Gilson Cesar Cardoso. São Paulo: Perspectiva, 2014.

ECO, Umberto. Seis passeios pelos bosques da ficção. Tradução: FEIST, Hildegard. São Paulo: Companhia das Letras, 2017.

ECO, Umberto. Pape Satàn Aleppe: crônicas de uma sociedade líquida. Tradução: AGUIAR, Eliana. Rio de Janeiro: Editora Record, 2017b.

ECO, Umberto. O Fascismo Eterno. Tradução AGUIAR, Eliana. Rio de Janeiro: Editora Record, 2018. 
ERNICA, Renato Razzino. A incompletude narrativa como efeito de sentido nos jogos digitais. In: Texto Digital, v. 10, n. 1, 2014, p. 46-75.

FIORIN, José Luiz. Em busca do Sentido: estudos discursivos. São Paulo: Editora Contexto, 2008.

FIORIN, José Luiz. Elementos de análise do Discurso. São Paulo: Editora Contexto, 2014.

FIORIN, José Luiz. As astúcias da Enunciação: as categorias de pessoa, espaço e tempo. São Paulo: Editora Contexto, 2016.

FRAENZA, Fernando. Filosofía natural de la imagen. Córdoba: Editoral Brujas, 2017.

GALLI, Fernanda Correa Silveira. Linguagem da internet: um meio de comunicação global. In: MARCUSCHI, Luiz Antônio; XAVIER, Antonio Carlos (orgs.). Hipertexto e gêneros digitais: Novas formas de construção de sentido. São Paulo; Cortez Editora, 2009. P. 147-164.

GENETTE, Gérard. Palimpsestos: a literatura de segunda mão. Tradução: BRAGA, Cibele, VIEIRA, Erika Viviane Costa, GUIMARÃES, Luciene, COUTINHO, Maria Antônia Ramos, ARRUDA, Mariana Mendes, VIEIRA, Miriam. Belo Horizonte: Edições Viva Voz, 2010.

GREIMAS, Algirdas Julien. Semântica Estrutural. Tradução: OSAKABE, Haquira, BLIKSTEIN, Izidoro. São Paulo: Editora Cultrix, 1973.

GREIMAS, Algirdas Julien. A Estrutura Semântica. In: GREIMAS, Algirdas Julien. Sobre o Sentido: Ensaios Semióticos. Tradução: CEZAR, Ana Cristina Cruz, FERNANDES, Ana Maria Sampaio, CHALITA, Katia Hakim, ALVIM, Clara de Andrade, PINTO, Maria Zélia Barbosa. Petrópolis: Editora Vozes, 1975, p. 36-45.

GREIMAS, Algirdas Julien. Acerca do Jogo. Tradução: PORTELA, Jean Cristtus. Significação Revista de Cultura Audiovisual, v. 34, n. 27, 2007.

GREIMAS, Algirdas Julien, COURTÉS, Joseph. Dicionário de Semiótica. Tradução: LIMA, Alceu Dias, BARROS, Diana Luz Pessoa de, CAÑIZAL, Eduardo Peñuela, LOPES, Edward, DA SILVA, Ignacio Assis, SOMBRA, Maria José Castagnetti, MIYAZAKI, Tieko Yamaguchi. São Paulo: Editora Contexto, 2008.

GREIMAS, Algirdas Julien. Sobre o Sentido II: Ensaios Semióticos. Tradução: DA CRUZ, Dilson Ferreira. São Paulo: Editora EDUSP, 2014.

HOGAN, Ron. Recreio Literário ou Uma Infância moldada pela Fic. In: JAMISON, Anne. Fic: Por que a fanfiction está dominando o mundo. Tradução: BARBÃO, Marcelo. Rio de Janeiro: Anfiteatro, 2017, p. 114-118.

HUIZINGA, Johan. Homo Ludens. Tradução: MONTEIRO, João Paulo. São Paulo: Perspectiva, 2014. 
JAMISON, Anne. Fic: Por que a fanfiction está dominando o mundo. Tradução: BARBÃO, Marcelo. Rio de Janeiro: Anfiteatro, 2017.

JENKINS, Henry. Textual Poachers: television, fans and participatory culture. Londres: Routledge, 1992.

JENKINS, Henry. Cultura da Convergência. Tradução: DE ALEXANDRIA, Susana L. São Paulo: Aleph, 2009.

JENKINS, Henry; GREEN, Joshua; FORD, Sam. Cultura da Conexão: criando valor e significado por meio da mídia propagável. Tradução: ARNAUD, Patrícia. São Paulo: Aleph, 2014.

JUUL, Jesper. The definitive history of games and stories, ludology and narratology. In: The Ludologist. Publicado em 22 de fevereiro de 2004. Disponível em: https://www.jesperjuul.net/ludologist/ (Acesso em 10 de janeiro de 2020).

JUUL, Jesper. Introduction to Game Time / Time to play - An examination of game temporality. In: WARDRIP-FRUIN, Noah; HARRIGAN, Pat (ed.). First Person: new Media as Story, Performance and Game. Massachusetts: MIT Press, 2004b. p. 131-142.

JUUL, Jesper. Half-Real: videogames entre regras reais e mundos ficcionais. Tradução: DA LUZ, Alan Richard. São Paulo: Editora Blucher, 2019.

KALIL FILHO, Marcos. A forma de vida neoliberal: o daily vlogger e a "empresa de si mesmo". Tese de Doutorado em Estudos de Linguagem. IL/UFF, 2020.

KOMESU, Fabiana Cristina. Blogs e as práticas de escrita sobre si na internet. In: MARCUSCHI, Luiz Antônio; XAVIER, Antonio Carlos (org.). Hipertexto e gêneros digitais: novas formas de construção de sentido. São Paulo; Cortez Editora, 2009, p. 135-146.

LOWOOD, Henry. A tecnologia encontrada: Jogadores como inovadores na produção de machinima. In: MORAN, Patrícia; PATROCÍNIO, Janaína (org.). Machinima. Tradução: SOARES, Gabriel Ribeiro. São Paulo; Pró-Reitoria de Cultura e Extensão Universitária da USP, 2011, p. 10-51.

MANCINI, Renata; SOUZA JÚNIOR, Paulo. Contar e participar: análise da tradução intersemiótica do videogame assassin's creed II para romance. Cadernos de Letras UFF. v. $27, \mathrm{n}$. 54, 2017, p. 23-40.

MANCINI, Renata. A tradução enquanto processo. Revista Cadernos de Tradução. v. 40, n. 3, 2020, p. 14-33.

MANCINI, Renata; LISBOA, Vinícius. Uma leitura tensiva das modalidades veridictórias. Tópicos del Seminario: Revista Semiótica. Dossiê: Claude Zilberberg: la semiótica tensiva. 2021 (no prelo). 
MARCUSCHI, Luiz Antônio. Gêneros textuais emergentes no contexto da tecnologia digital. In: MARCUSCHI, Luiz Antônio; XAVIER, Antonio Carlos (org.). Hipertexto e gêneros digitais: Novas formas de construção de sentido. São Paulo: Cortez Editora, 2009. P. 15-80.

MARINO, Gabriele. Qual semiótica da propagabilidade: uma abordagem sistemática de memes e virais de Internet. Revista Ícone, v. 16, n, 1, 2018, p. 9-40.

MURRAY, Janet H. Hamlet no Holodeck: O futuro da narrativa no ciberespaço. Tradução: DAHER, Elissa Khoury, CUZZIOL, Marcelo Fernandez. São Paulo: Editora Unesp, 2003.

POTTIER, Bernard. Linguística geral: Teoria e descrição. Tradução: MACEDO, Walmírio. Rio de Janeiro: Presença e Universidade Santa Úrsula, 1978.

PROPP, Vladimir I. Morfologia do conto maravilhoso. Tradução: SARHAN, Jasna Paravich. Rio de Janeiro: Editora Forense Universitária, 2010.

ROSENFELD, Anatol. Literatura e Personagem. In: CANDIDO, Antônio (et.al.). A Personagem de Fiç̧ão. São Paulo: Perspectiva, 2014.

SALEN, Katie; ZIMMERMAN, Eric. Regras do Jogo: Fundamentos do Design de Jogos, Volume 2. Tradução: FURMANKIEWICZ, Edson. São Paulo: Editora Blucher, 2016a.

SALEN, Katie; ZIMMERMAN, Eric. Regras do Jogo: Fundamentos do Design de Jogos, Volume 3. Tradução: FURMANKIEWICZ, Edson. São Paulo: Editora Blucher, $2016 \mathrm{~b}$.

SCHWARTZMANN, Matheus Nogueira. A noção de texto e os níveis de pertinência da análise semiótica. In: Estudos Semióticos, Edição especial, No. 14, 2018, p. 1-6.

SILVA JÚNIOR, Mário Sérgio Teodoro da. Apontamentos sobre a narratividade e a aspectualização do ato de jogar no jogo Super Mario World. In: Texto Livre - Linguagem e Tecnologia, V. 12, No. 1, 2019, p. 85-111.

SPAZIANTE, Lúcio. Sociosemiotica del Pop: Identità, testi e patriche musicali. Roma : Carocci Editore, 2007.

TANNEN, Deborah. Talking Voices: Repetition, Dialogue, and Imagery in Conversational Discourse. Cambridge: Cambridge University Press, 2007.

TATIT, Luiz. No calor da obra: Encontros com a produção cultural contemporânea. Entrevista com Luiz Tatit. In: Revista Letras, No. 52, 1999, p. 215-239.

TATIT, Luiz. Semiótica à luz de Guimarães Rosa. Cotia: Ateliê Editorial, 2010.

TODOROV, Tzvetan. Introdução à Literatura Fantástica. Tradução: CASTELLO, Maria Clara Correa. São Paulo: Perspectiva, 2017. 
WONG, Wucius. Princípios de Forma e Desenho. Tradução: LAMPARELLI, Alvamar Helena. São Paulo: Martins Fontes, 2001.

XAVIER, Antonio Carlos. Leitura, texto e hipertexto. In: MARCUSCHI, Luiz Antônio; XAVIER, Antonio Carlos (orgs.). Hipertexto e gêneros digitais: Novas formas de construção de sentido. São Paulo: Cortez Editora, 2009. P. 207-220.

\section{REFERÊNCIAS DE JOGOS}

BLIZZARD ENTERTAINMENT; IRON GALAXY STUDIOS. Overwatch. Irvine: Blizzard Entertainment, 27 out. 2015. Jogo de videogame (mídia digital: Microsoft Windows, Playstation 4, Nintendo Switch, Xbox One).

RIOT GAMES. League of Legends. California: Riot Games, 27 out. 2009. Jogo de videogame (mídia digital: Microsoft Windows, MacOs).

\section{REFERÊNCIAS DE SITES}

REDDIT. Disponível em: <https://www.reddit.com/>. Acesso em: 11 mar. 2021.

TWITTER. Disponível em: <https://twitter.com/home>. Acesso em: 11 mar. 2021.

IMGUR. Disponível em: <https://imgur.com/>. Acesso em: 11 mar. 2021.

DANBOORU. Disponível em: <https://danbooru.donmai.us/>. Acesso em: 11 mar. 2021.

RULE 34. Disponível em: <https://rule34.paheal.net/>. Acesso em: 11 mar. 2021.

ARCHIVE OF OUR OWN. Disponível em: <https://archiveofourown.org/>. Acesso em: 11 mar. 2021.

FANDOM. Disponível em: <https://www.fandom.com/>. Acesso em: 11 mar. 2021.

GAMEPEDIA. Disponível em: <https://www.gamepedia.com/>. Acesso em: 11 mar. 2021.

YOUTUBE. Disponível em: <https://www.youtube.com/>. Acesso em: 11 mar. 2021.

OVERWATCH. Disponível em: <https://playoverwatch.com/pt-br/>. Acesso em: 11 mar. 2021.

LEAGUE OF LEGENDS. Disponível em: <https://na.leagueoflegends.com/pt-br/>. Acesso em: 11 mar. 2021. 


\section{GLOSSÁRIO}

Actantes - Segundo Pessoa de Barros (2005), o actante é "uma entidade sintática da narrativa". Os actantes são recobertos pelos atores quando analisados no nível discursivo (o sujeito vira o cavaleiro e o anti-sujeito vira o dragão). Porém é importante frisar que um actante pode ser representado por diversos atores, bem como um mesmo ator pode incorporar diversos papéis actanciais.

Actorialização - Segundo Greimas \& Courtés (2008), a actorialização é um dos componentes da construção do discurso, junto com a espacialização e a temporalização. A actorialização é o processo de instituir e constituir os atores do discurso, por exemplo como a definição de um narrador presente ou ausente. Responsável pela atribuição do Eu - Tu - Ele do discurso.

Arquitextualidade (Genette) - Segundo o autor, a Arquitextualidade é a relação de um texto com textos preexistentes que são similares a ele, considerados como parte de uma tradição coerente. Ainda segundo o autor, gênero e estilo são conceitos importantes no nível arquitextual de um texto.

Atores (semiótica) -Os atores são os recobrimentos figurativos aplicados aos actantes no nível

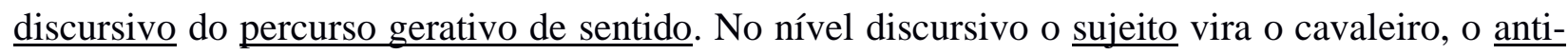

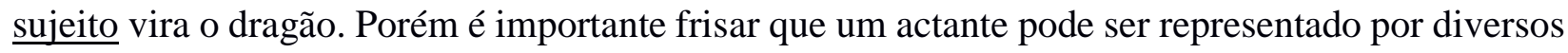
atores, bem como um mesmo ator pode incorporar diversos papéis actanciais.

Axiologia (semiótica) - Segundo Greimas \& Courtés (2008), a axiologia na semiótica é qualquer categoria semântica representada no quadrado semiótico. Nesta axiologia, um termo é investido de um valor positivo (ou eufórico), e outro é investido de valor negativo (disfórico). Estas axiologia pode ser de caráter abstrato ou figurativo.

Bugs (Jogos) - Bug (o termo na área de informática possui uma origem contestada, mas significa "inseto" em inglês) é o jargão que define uma falha na programação de um jogo. Este termo difere do termo Glitch pois, quando um bug é acionado na programação de um jogo, ele acaba por fazer o jogo parar de funcionar ( $c r a s h$ ), sendo geralmente considerado um problema de grande porte num jogo. 
Buff (jogos) - Termo utilizado na comunidade de desenvolvimento de jogos, Buff significa uma modificação (chamada de $\underline{\text { Patch }}$ ) em algum elemento de um jogo posterior ao seu lançamento, com o objetivo de torná-lo mais eficaz ou mais poderoso. A origem do termo é estadunidense, relativo ao termo usado para descrever os pelos que protegem o Búfalo na natureza. É o termo contrário de Nerf.

Canon/Canônico (internet) - Em seu uso corrente na internet, um termo, interpretação ou texto é considerado canônico quando se refere a um evento sancionado pelo universo oficial do jogo, que é de controle dos produtores do referido jogo. Toda a informação que não é considerada canônica, é de autoria do Fandom, como memes e fanfics.

Contrato (semiótica) - Termo usado na semiótica para descrever, em termos gerais, uma relação intersubjetiva com o objetivo o estabelecimento de condições. Existem contratos fiduciários, que é estabelecida a respeito de um objeto de valor, geralmente consequência de uma manipulação de um destinador. Podem também ser os contratos de veridicção, que define os acordos entre enunciador e enunciatário sobre os regimes veridictórios de um discurso.

Crossover (fandom) - Crossover é o nome dado à prática dos fãs (e, em certas ocasiões, de publishers e empresas) de fazer com que universos de fantasias diferentes se encontrem num mesmo texto. Tal prática pressupõe o embate e adequação entre Formas Científicas diferentes, o que por si só é parte do interesse que tais acontecimentos geram.

Cybertexto (Aarseth) - De acordo com Aarseth (1997), o cybertexto é uma prática de organização textual, em que o fluxo de leitura pressupõe uma resposta interativa das decisões do leitor. Num cybertexto não há a possibilidade da visualização simultânea da totalidade textual, pois o sentido depende das decisões do leitor. Um exemplo de cybertexto é a ferramenta de hipertextos, que organiza wikis na internet, por exemplo.

Debreagem (Fiorin) - De acordo com Fiorin (2016), a Debreagem é uma operação que "disjunge de si e projeta para fora de si, no momento da discursivização, certos termos ligados à sua estrutura de base com vistas à constituição dos elementos fundadores do enunciado, isto é, pessoa, espaço e tempo". Existem dois tipos de Debreagem: 
- Enunciativa, onde são marcados os elementos de pessoa (eu-tu) /espaço (aqui) /tempo (agora) da enunciação, como por exemplo quando lemos um romance de época em que o protagonista "fala" com o leitor.

- Enunciva, onde são marcados os elementos de pessoa (ele) /espaço (alhures) /tempo (então) do enunciado, como por exemplo na linguagem científica e acadêmica.

Easter Egg (jogos) - No seu uso corrente dentro da internet, Easter Egg (termo em inglês para "Ovos de Páscoa", em função da tradição pascoal de buscar os ovos de chocolate escondidos durante as festas) é qualquer informação, escondida dentro do jogo, que faça uma referência a algum outro elemento, seja do universo do jogo, seja de outros universos de outros jogos. Os Easter Eggs costumam ser uma forma dos desenvolvedores do jogo realizarem "acenos" ao fandom, referenciando teorias ou piadas internas que comprometeriam o universo fantasioso caso fossem tratadas como canônicas.

Embreagem (Fiorin) - Segundo Fiorin (2016), a Embreagem é uma operação que cria um “'retorno de efeito à enunciação', produzido pela neutralização das categorias de pessoa e/ou espaço e/ou tempo, assim como pela denegação da instância do enunciado. Uma embreagem sempre pressupõe que tenha ocorrido uma debreagem anterior.

Enunciador (semiótica) - No nível discursivo do percurso gerativo de sentido, é o enunciador implícito da comunicação, quem enuncia o discurso. Que difere de um narrador, pois não é um actante do discurso.

Enunciatário (semiótica) - No nível discursivo do percurso gerativo de sentido, é o enunciatário implícito na comunicação, para quem o discurso é enunciado. Difere de um narratário, pois não é um actante do discurso.

Ergódica (Aarseth) - Tradução do inglês Ergodic, que por sua vez é uma junção dos termos gregos Ergon (trabalho) e Hodos (caminho), é um termo proposto por Espen Aarseth (1997) para definir o processo de leitura de um cybertexto, em que o leitor avança em seu processo semiótico de leitura pulando através de diversos hiperlinks, buscando criar o seu sentido máximo de apreensão. 
Espacialização - Segundo Greimas \& Courtés (2008), a espacialização é um dos componentes da construção do discurso, junto com a actorialização e a temporalização. A espacialização é o processo de instituir e constituir as referências espaciais do discurso, por exemplo como a definição de um espaço definido ou não num texto. Responsável pela atribuição do Aqui - Lá - Alhures do discurso.

Ethos (discurso) - De acordo com Fiorin (2008), o ethos é o "autor ideal", o recobrimento de traços que definem quem enuncia o discurso. O ethos do enunciador é o conjunto de traços identificado num conjunto de obras (como o ethos do autor Machado de Assis). Junto com o $\underline{\log O S}$ e o pathos, o ethos constitui uma das bases da argumentação.

Fandom (internet) - É uma aglutinação entre as palavras Fan e Domain, é considerado o espaço digital (sites e fóruns) onde os fãs se encontram e exercem suas interações sobre as narrativas que admiram.

Fic/Fanfic (Jamison) - De acordo com Jamison (2017) a fanfic/fic (ambas abreviações do termo fanfiction) é a atividade em que uma pessoa produz uma narrativa utilizando os universos ficcionais criados por outro indivíduo.

Figura/Figurativização (semiótica) - Na semiótica, a figurativização é o recobrimento da narrativa, que localiza a corporeidade do texto, bem como os valores socio-histórico-políticos invocados pelo discurso.

Flow (Cziksentmihalyi) - Termo cunhado pelo psicólogo Mihaly Cziksentmihalyi (2008) para definir o efeito de satisfação que se pode atingir durante uma atividade, quando há um equilíbrio entre a ansiedade do desafio e o tédio do domínio. É um conceito conhecido dentro do desenvolvimento de logos, sendo citado por Juul (2019) e Salen \& Zimmerman (2016a).

Freemium - uma aglutinação dos anglicismos "free" (um jogo de graça) e "premium" (recursos pagos e exclusivos). É um termo aplicado popularmente para designar jogos em que a atividade de jogar e utilizar os recursos é gratuita, porém o acesso a elementos específicos do jogo que não são necessários, mas facilitam e potencializam o desempenho do jogador, são pagos. 
Forma Científica (Beividas/Greimas) - É o termo proposto por Beividas (2015) a partir das propostas de Greimas (1975), que se refere aos elementos linguageiros que são estabelecidos no momento da escolha dos elementos nomeáveis em uma dada linguagem. Comparável ao exemplo, muitas vezes usado ao se falar de linguagem, do esquimó que possui 15 nomes para os diferentes tipos de neve, enquanto outra linguagem pode possuir apenas um. É uma forma estabelecida como anterior ao nível fundamental.

Forma Semiótica (Beividas/Greimas) - É o termo proposto por Beividas (2015) a partir das propostas de Greimas (1975), que se refere aos elementos linguageiros que são estabelecidos durante o percurso gerativo de sentido, o conjunto hierarquizados de semas e suas relações constitutivas.

Forma Códica (Beividas) - É o termo proposto por Beividas (2015) a partir das propostas de Greimas (1975), que se refere aos elementos linguageiros que são característicos da manifestação do discurso. É o modo como os sememas são constituídos dentro do discurso.

Fórum (internet) - Um fórum de internet é geralmente um site (como o Reddit) ou uma parte de um site maior (como os sites oficiais de League of Legends e Overwatch) dedicado à interação entre desenvolvedores, fãs e usuários de um jogo, uma mídia social ou outro produto. No Fórum, cada usuário pode ter um perfil, com o qual é possível Postar ou responder em Threads de discussão.

Glitches (jogos) - Glitch (o termo na área de informática possui uma origem contestada, mas significa “escorregar" em Alemão e Ídiche) é o jargão que define uma inconsistência na programação de um jogo. Este termo difere do termo $\underline{B u g}$ pois, quando um glitch é acionado na programação de um jogo, ele geralmente cria resultados visuais/auditivos inesperados, como sobreposição de elementos visuais (clipping) ou áudios inesperados, mas não impede o funcionamento dos demais elementos da programação do jogo.

Hardware - Termo genérico para nomear os aparelhos físicos que, de acordo com Salen \& Zimmerman (2012) são utilizados pelo jogador para uma interação "imediata, mas limitada" com a programação do jogo de videogame. Exemplos de hardware são mouse, teclado, monitor, computador, console, microfone etc. 
Hipertexto (Aarseth/Xavier) - Segundo Aarseth (1997), o hipertexto é o texto que promove um vínculo de sentido de leitura entre trechos localizados em espaços diferentes, amplamente utilizado no princípio de leitura ergódica. Hipertextos são amplamente utilizados em sites e wikis, sendo chamados de hiperlinks. Para Xavier (2009) o hipertexto é uma forma híbrida, dinâmica e flexível de linguagem que dialoga com outras interfaces semióticas, adiciona e acondiciona à sua superfície formas outras de textualidade.

Hipertextualidade (Genette) - Segundo Genette (2010), a Hipertextualidade é o processo em que um texto é gerado a partir de outro texto. $\mathrm{O}$ autor divide estas hipertextualidade em duas categorias. A transformação (que pode ser uma paródia lúdica, um travestimento satírico, ou a transposição como uma tradução) e a Imitação (como o Pastiche lúdico, a Charge satírica ou uma Forjação, de cunho mais sério).

Idioleto - Segundo Greimas e Courtés (2008) o idioleto é um "fenômeno de superfície, que afetam, em primeiro lugar, os componentes fonético e lexical da língua". Segundo os autores, o idioleto pode ser aproximado do conceito de estilo do enunciador, as atividades semióticas de um ator individual. Um exemplo deste conceito é a categoria de "textos machadianos", que possuiriam o mesmo idioleto atribuído a Machado de Assis.

Intertextualidade (Genette) - Segundo Genette (2010), a intertextualidade é a relação que um texto com outro ou vários que se incluem nele em vários graus. Alguns exemplos são a Alusão (a citação indireta a outro texto), Citação (referência direta e transcrita a um outro texto) e Plágio (Absorção de um texto externo no texto).

Isotopia (semiótica) - Segundo Fiorin (2009), a Isotopia consiste na "recorrência de um dado traço semântico ao longo de um texto. Para o leitor, a isotopia oferece um plano de leitura, determina um modo de ler o texto". De acordo com o autor "Essa leitura não provém da fantasia do leitor, mas está inscrita no texto". Fiorin porém pondera que "Há alguns discursos que articulam duas ou mais isotopias e outros que se desenvolvem simultaneamente sobre vários planos isotópicos", permitindo o que chama de pluri-isotopia.

Jectal (Tatit) - Segundo Luiz Tatit (1999), o elemento jectal (o verbo jéter, que no francês significa jogar, lançar) é o termo comum entre as palavras "sujeito" e "objeto", significando o 
elemento que lança o objeto para dentro do sujeito, e o sujeito em busca do objeto, transformando a relação em algo semioticamente existencial para ambos.

Lexema (Semântica) - Segundo Greimas \& Courtés (2008), o lexema é uma unidade de sentido sêmico resultante da reunião de diferentes sememas, como que um conjunto de possibilidades de uso dentro de uma narrativa.

Logos (discurso) - Segundo Fiorin (2008), logos é o conhecimento contido na própria comunicação. Junto com o ethos e o pathos, o logos constitui uma das bases da argumentação.

Ludologia (Juul) - É, segundo Juul (2019), o “estudo dos jogos". Durante os anos 90, houve um princípio de antagonismo no campo dos estudos de jogos entre uma abordagem narratológica mais radical (a história contada no jogo predominava sobre sua mecânica) e a Ludologia também mais radical (a mecânica do jogo era predominante sobre sua história). Nos últimos anos, a Ludologia se ocupa com o estudo dos jogos, considerando a relação entre a narrativa e a mecânica como uma característica constitutiva deste tipo de meio.

Macrotexto - No contexto desta pesquisa, o Macrotexto é o texto ergódico que engloba o conjunto fórum-jogos, e que é composto por diversas unidades textuais menores.

Manifestação Cultural Dominante (Canclini) - Termo proposto por esta pesquisa, a partir das observações de Canclini (2007), de que uma determinada cultura não é uma estrutura estável, mas sim a resultante de diversas relações de conflito e dominância entre manifestações culturais diversas. Neste contexto, a Manifestação Cultural Dominante é a cultura que domina o ambiente da internet, possuindo uma ideologia branca, masculina, cis gênero, heteronormativa, ocidental, cristã e capitalista.

Manipulação (semiótica) - Em termos semióticos, é a etapa inicial do nível narrativo, em que um destinador faz um destinatário crer nos valores de um determinado objeto de valor, transformandoo em um sujeito que dará início a sua performance, a etapa da ação.

Meme (Dawkins/Marino) - Termo proposto por Dawkins (2007), um neologismo a partir da palavra grega mimeme (imitação) e da palavra francesa même (memória), o meme define um elemento cultural que se propaga da mesma forma que o gene, descrito por Dawkins. Dentro da 
semiótica, consideraremos a interpretação de Marino (2018) sobre o princípio de Dawkins, de que o meme é um elemento do tipo punctum que provoca uma atenção particular no observador, convidando-o promover tal sensação dentro do continuum memético da internet, através de $\underline{\text { samplings, }}$ remixes e remakes.

Meta (jogos) - Na acepção desta pesquisa, o Meta é uma abreviação do anglicismo Metagaming, usado principalmente pela comunidade de League of Legends para se referir ao modo e ao conhecimento de quais são as estratégias e formas padrão de se jogar um jogo, como se fossem as convenções e a etiqueta que cada jogador utiliza. No caso de LOL e Overwatch o conceito de Meta tem relação com as convenções de utilização do elenco de campeões e heróis, nos moldes que eles foram originalmente planejados pelos desenvolvedores. Jogadores que usem uma personagem do tipo "tanque" para atacar na linha de frente ou um personagem que aplica muito dano apenas para dar cobertura costumam ser acusados de "jogar contra o meta", pois suas práticas seriam consideradas confusas e contraproducentes.

Metatextualidade (Genette) - De acordo com o autor, a metatextualidade é a relação de um texto com um ou vários textos que este comenta, explica etc. Umberto Eco (2017) chama esta metatextualidade de análises, críticas de um texto, avaliações dentre outros.

MOBA (jogos) - Sigla em inglês para Massive Online Battle Arena (Arena de batalhas massivas online), gênero de jogo caracterizado por um cenário fechado aonde diversos jogadores em diferentes computadores se enfrentam em partidas.

Mods (jogos) - Mod é a abreviação da palavra anglicana modification (modificação), e serve para definir alterações de caráter não-oficial, feitas por fãs, na programação e nos atributos de um jogo. Geralmente estas alterações são de caráter estético, como skins para personagens, porém existem mods mais complexos que podem alterar também as regras da programação do jogo. Lowood (2011) considera que tais mods contribuem para alongar a "vida útil" de um jogo em manter o interesse de seus fãs.

Morfema (linguística) - Segundo Greimas e Courtés (2008) o morfema é a parte da palavra que indica a sua função, pode ser considerado como uma unidade mínima de análise gramatical, antes da entrada no campo fonológico. 
Mundo das coisas (semiótica) - Termo utilizado por Pessoa de Barros (1988) para descrever o mundo físico cuja existência independe do discurso analisado. Este termo é análogo ao termo "Mundo natural", proposto por Greimas \& Courtés (2008), definido como um conjunto de qualidades sensíveis e de ordem física, química, biológica etc.

Narratologia (Todorov) - Termo cunhado por Todorov (1969) para o campo de estudo que analisa as narrativas e suas estruturas, e a forma como estar interferem na sociedade. Considerada área de atuação de autores como Todorov, Bakhtin e Propp.

Nerf (jogos) - Termo utilizado na comunidade de desenvolvimento de jogos, Nerf significa uma modificação (chamada de $\underline{\text { Patch }}$ ) em algum elemento de um jogo posterior ao seu lançamento, com o objetivo de torná-lo menos eficaz ou menos poderoso. A origem do termo vem de uma linha de brinquedos (Nerf Gun) de tiro em que os projéteis são feitos de uma espuma que tem por objetivo não machucar os usuários. É o termo contrário de $\underline{B u f f}$.

Nível Discursivo - Nível mais superficial do Percurso Gerativo de Sentido, onde é aplicado o recobrimento figurativo à narrativa estruturada no nível narrativo. Neste nível os actantes se transformam em atores socio-culturalmente localizados no mundo das coisas, bem como são criadas as figuras "observáveis" num texto.

Nível Fundamental - Nível mais profundo do Percurso Gerativo de Sentido, é o nível onde se instaura uma oposição axiológica entre dois termos - um eufórico e outro disfórico - a partir dos quais são estabelecidos os valores que organizarão o nível narrativo.

Nível Narrativo - Nível intermediário do Percurso Gerativo de Sentido, é onde os valores presentes no nível fundamental são narrativizados a partir do modelo Proppiano, onde são apontados os actantes (sujeito, anti-sujeito, objeto, etc.) e onde se estrutura a modalização do sujeito para que este exerça suas performances, moldando o mundo.

Objeto de Valor - Dentro do percurso gerativo de sentido, especificamente no nível narrativo, o objeto de valor é o actante onde o sujeito projeta seus desejos e o objetivo da busca que movimenta a narrativa. Sujeito e Objeto de valor são os dois polos da relação jectal em que se expressam os valores do discurso. 
Patch (jogos) - O termo Patch (do inglês, Retalho), é um jargão no desenvolvimento de jogos para nomear as atualizações que são periodicamente feitas em jogos online como League of Legends e Overwatch. Estes Patchs servem para inserir atualizações, como novos cenários, funcionalidades ou personagens, bem como a aplicação de $\underline{B u f f s}$ ou Nerfs em elementos pré-existentes.

Paratextualidade (Genette) - De acordo com o autor, a paratextualidade é a relação de textos acessórios que ajudam a constituir um texto. Exemplos de paratextos são títulos, subtítulos, capas, páginas de sites, notas de rodapé, ilustrações etc.

Pathos (discurso) - Segundo Fiorin (2008), o pathos é o "leitor ideal", um conjunto de traços que identifica a quem é enunciado um texto. O pathos não é a disposição real do enunciatário, mas sim a imagem que o enunciador faz do enunciatário. Junto com o $\underline{\text { ethos }}$ e o logos, o pathos constitui uma das bases da argumentação.

Perfil (internet) - Os perfis são identidades que podem enunciar discursos dentro dos fóruns, criadas pelos usuários de acordo com as regras e funcionalidades vigentes dentro do site em que ele será utilizado. A quantidade de informação que um perfil possui pode variar. Vale notar que ao comunicar-se no ambiente digital, o usuário médio não possui métodos para comprovar se o conteúdo de um perfil com o qual se interage possui correspondência com o mundo natural ou não. Portanto, a incerteza e a dúvida sobre a legitimidade de um perfil são parte de seu ethos como enunciador ou enunciatário.

Percurso Gerativo de Sentido - Segundo Pessoa de Barros (2005), o percurso gerativo de sentido é um modelo semiótico para "construir o sentido do texto", este percurso conta com três níveis (Nível Fundamental, Nível Narrativo e Nível Discursivo), organizados do mais elementar ao mais complexo, respectivamente. Estes níveis descrevem percurso narrativo do Sujeito do texto em busca de seu Objeto de Valor, e a busca dos meios modais para fazê-lo (chamados na semiótica de

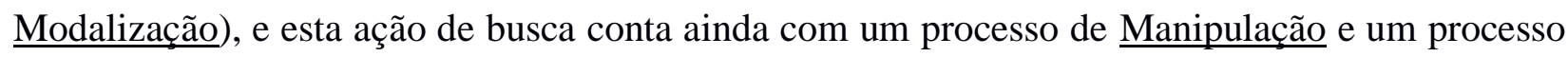
de $\underline{\text { Sanção. }}$

Postagem (internet) - Postagem é um neologismo construído a partir da palavra Post, utilizada para descrever uma mensagem texto-visual em um Fórum na internet, e à qual geralmente inaugura 
ou compõe uma Thread de mensagens. A palavra postar já costuma ser utilizada no Brasil de maneira conjugada, "postei", "postando" etc.

Projeto Enunciativo (Mancini) - Segundo Mancini (2020), o projeto enunciativo pode ser definido como a "alma do texto", um conjunto de estratégias de textualização que visam concretizar um projeto de veridicção e persuasão em um texto. Este projeto enunciativo pode ser considerado o "resultado ideal" do texto em relação a seu enunciatário.

Pseudociência (fantasia) - Termo proposto por esta pesquisa para se referir, no contexto da forma científica proposta por Greimas (1975) e Beividas (2015), aos cânones das ciências fantasiosas dos universos de LOL e Overwatch, responsáveis por definir os lexemas criados pelos respectivos universos ficcionais.

Punctum (Barthes) - Segundo Barthes (2015), o Punctum (o que me punge) é um objeto parcial que toma a atenção do observador, e a ressignifica como uma nova imagem. Em análise da relação entre foto, observador, fotógrafo e fotografado, Barthes propõe uma oposição entre o Studium (um afeto médio, interesse humano pela cultura apresentada na foto) e o Punctum (elemento marcante e perfurante que punge o observador).

Ratio Difficilis (Eco) - De acordo com Umberto Eco (2017), a ratio difficilis é "quando uma ocorrência expressiva concorda diretamente com o seu conteúdo, seja porque não existe tipo expressivo performado, seja por que o tipo expressivo já é idêntico ao tipo de conteúdo". A ratio difficilis é uma situação em que se fazem operações de instituição de código. Tal processo de invenção não equivale, porém, num processo de "criatividade gerida pelas regras" (que é o território da Ratio Facilis), mas sim num processo de "criatividade que muda as regras", propondo um novo modo de codificar.

Ratio Facilis (Eco) - De acordo com Umberto Eco (2017), a ratio facilis é "quando uma ocorrência expressiva concorda com o seu tipo expressivo, conforme foi institucionalizado por um sistema da expressão e - como tal - previsto pelo código". São exemplos de ratio facilis as réplicas de um objeto, ou sinais de trânsito: o raciocínio é que "para produzir um significante que signifique $\mathrm{X}$, deve-se produzir um objeto construído de modo $\mathrm{Y}$ - modo prescrito pelo tipo provido pelo sistema de expressão". 
Remaking (Spaziante) - Chamado também de "reinterpretação", é o termo proposto por Spaziante (2007) para se referir à recriação de um texto pré-existente. Sendo considerada a terceira e última etapa de desenvolvimento do continuum memético.

Remixing (Spaziante) - Chamado também de "reinterpretação manipulativa", é o termo proposto por Spaziante (2007) para se referir à modificação/reapropriação de um texto pré-existente. Sendo considerada a segunda etapa de desenvolvimento do continuum memético.

Respawn (jogos) - Um neologismo anglicano (re-spawn = re-gerar/regenerar) é o nome atribuído a uma mecânica recorrente em muitos jogos multijogador: quando um jogador é eliminado da partida, após um determinado período de tempo (que serve como sanção negativa ao desempenho do programa de base de jogador na partida), ele poderá renascer dentro da base de seu time, e assim retornar à partida.

Sampling (Spaziante) - Chamado também de "reinterpretação apropiativa", é o termo proposto por Spaziante (2007) para se referir à extração de um texto pré-existente. Sendo considerada a primeira etapa de desenvolvimento no continuum memético.

Sanção (semiótica) - No nível narrativo do percurso gerativo de sentido, a sanção é a terceira e última etapa, onde a ação do sujeito é julgada a partir do contrato fiduciário contraído na etapa da manipulação. Pessoa de Barros (1988) propõe que exista uma etapa equivalente à sanção no percurso temático de comunicação e de produção, ambos no nível discursivo, onde o discurso do enunciador é sancionado quanto à sua eficácia.

Sandbox (jogos) - São tipos de jogos caracterizados pelo encorajamento a uma modalidade de jogo considerada mais livre. A maioria dos jogos sandbox são não-lineares (ou possuem pouca linearidade), uma grande quantidade de elementos interativos, objetivos e regras mínimos. Segundo S. Breslin o próprio nome sandbox refere-se à caixa de areia em que crianças brincam, aonde a partir de materiais disponíveis dentro de tal caixa, a criança constrói o mundo de sua brincadeira; no mesmo princípio, os jogos sandbox almejam oferecer um ambiente digital interativo onde os jogadores explorem os efeitos de suas ações em tal espaço.

Semas (semiótica) - De acordo com Greimas e Courtés (2008), um sema é a unidade mínima da significação, situado no plano do conteúdo. Resultado do desvio diferencial em relação a outros 
semas, só podem ser apreendidos no interior da estrutura elementar da significação. O termo "mínimo", no caso dos semas, possui uma acepção relativa, pois sempre vai depender do campo de exploração escolhido, não possuindo assim uma listagem universal.

Semântica (discurso) - Segundo Pessoa de Barros (2005), a semântica discursiva examina a disseminação dos temas num discurso, sob a forma de percursos e o investimento figurativo dos percursos. Segundo Greimas e Courtés (2008), se buscarmos por exemplo um texto que, no nível fundamental, opõe liberdade (eufórico) e prisão (disfórico), no nível narrativo, esta oposição será desenvolvida num percurso em que o sujeito busca o objeto de valor "liberdade". No nível discursivo, por fim, o tema da liberdade pode ser reconhecido pelas figuras de uma torre representando a prisão, e o resgate de um cavaleiro representando a liberdade, tendo como modelo por exemplo, a fábula de Rapunzel.

Semelhança de Família (Eco) - De acordo com Eco (2000, 2018) a semelhança de família é o fenômeno interpretativo em que, mesmo que dois elementos não possuam, a princípio, nenhuma relação, sua aparição reincidente junto a objetos que possuam relação entre si de fato, acaba por gerar a interpretação de que tais elementos são relacionados.

Semema (linguística) - Segundo Pottier (1978), o semema é um conjunto de semas que caracterizaria a acepção de um lexema, como se fosse uma das definições possíveis de uma palavra em um dicionário. De acordo com Greimas \& Courtés (2008), o semema pode possuir um núcleo sêmico, uma parte invariável do lexema, e que, junto de alguns semas contextuais, forma um semema.

Ships (internet) - Ship é o sufixo comum em termos como Friendship (amizade) e Relationship (relacionamento). Segundo Jamison (2017), dentro do Fandom, o ship é o desejo de que dois personagens estejam em um tipo de relacionamento. Existem inclusive categorias específicas de ship: Slash (homem/homem), Femslash (mulher/mulher) e Enemyslash (personagens que são inimigos no texto original). O princípio básico de um Ship é que envolva o desejo de uma profunididade de relacionamento entre dois personagens maior do que a apresentada no texto de origem. 
Sintaxe (discurso) - Segundo Pessoa de Barros (2005), a sintaxe explica as relações do sujeito da enunciação com o discurso enunciado e também as relações "argumentativas" que se estabelecem entre enunciador e enunciatário. De acordo com Greimas e Courtés (2008), as ferramentas de $\underline{\text { debreagens }}$ e embreagens, bem como os procedimentos de actorialização, espacialização e $\underline{\text { temporalização, }}$ são as formas de estudar os elementos que constituem o sujeito da enunciação como um todo.

Skin (jogos) - Anglicismo referente à pele no inglês. Recurso presente em muitos jogos, é um recurso estético que permite alterar o mapa de textura do avatar do jogador, com o intuito de permitir que este jogue colocando "roupas" diferentes na sua personagem. Do ponto de vista da semiótica, pode servir como sanção pragmática e cognitiva pelas habilidades do jogador, comemoração de eventos ou elemento cosmético de compra, altera o recobrimento figurativo do

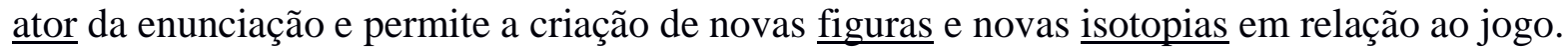

Socioleto - Segundo Greimas e Courtés (2008), o socioleto “caracteriza o fazer semiótico em suas relações com a estratificação social", é através do socioleto que se pode localizar a classe social, tempo e espaço de um enunciador/produtor, através das "varrições semióticas que os opõem uns aos outros (é seu plano de expressão) e pelas conotações sociais que os acompanham (é seu plano de conteúdo)". Um exemplo dessa categoria são os traços que permitem identificar um grupo de autores com o "Romantismo do século XIX".

Software - Termo genérico para nomear os aplicativos e programas que, de acordo com Salen e Zimmerman (2012), contém os sistemas complexos automatizados que guiam as regras execução e interação dentro de um videogame.

Spectrum (Barthes) - De acordo com Barthes (2015) o spectrum é uma das práticas da fotografia, que é a prática de quem é fotografado. O autor vê isso como a prática de quem tenta passar uma imagem específica, mas depende da interação com o fotógrafo (operator) e da leitura do público (spectator). Trazendo ao spectrum uma sensação de impotência, que tange à ambiguidade.

Studium (Barthes) - Segundo Barthes (2015), o Studium (latim da palavra estudo) é uma relação de afeto médio com uma foto, em que o observador entra em concordância com o discurso cultural proposto pelo fotógrafo. Em análise da relação entre foto, observador, fotógrafo e fotografado, 
Barthes propõe uma oposição entre o Studium (um afeto médio, interesse humano pela cultura

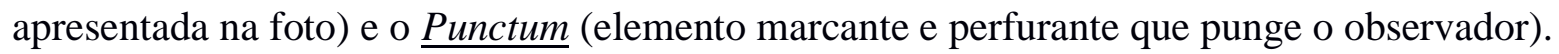

Sujeito (semiótica) - De acordo com Pessoa de Barros (2005), o sujeito é um actante da narrativa, que se define por sua relação de busca pelo objeto de valor. A principal característica do sujeito dentro da narrativa são seus diversos papéis actanciais, que se alteram à medida que a narrativa prossegue, como o papel do "sujeito competente" e do "sujeito realizador da performance". Greimas e Courtés (2008) definem o sujeito dentro na narrativa como o actante que "concebe sua vida enquanto projeto, realização e destino".

Sujeito da enunciação - De acordo com Pessoa de Barros (1988), dentro do nível discursivo, o percurso de produção do discurso é idealizado por um produtor. Este busca criar um ethos de enunciador e um pathos de enunciatário, para que o discurso se torne eficaz em sua função de convencer alguém a julgar a veridicção de tal enunciado como verdadeira. Como tal ethos e tal pathos são criados pelo mesmo produtor, no percurso de produção, o enunciador (ethos) e enunciatário (pathos) são sincretizados como o sujeito da enunciação.

Tag (internet) - Anglicismo criado a partir da palavra inglesa tag (etiqueta), representa uma informação que pode ser inserida nos metadados de um texto ou imagem, e permitem que tal texto (e todos os que possuam a mesma tag) possa ser pesquisado via hipertextos ou bancos de dados.

Tecnoleto (Galli) - De acordo com Galli (2009), o termo Tecnoleto é frequentemente denominado língua de especialidade (a partir do francês langue de spécialité), porém, existem críticas a esta designação, em função do uso impróprio do termo "língua", sendo preferível o uso do termo tecnoletos. Se refere a uma espécie de vocabulário técnico, transportado para o uso na língua comum, que demarca especificidades comunicativas de um determinado grupo social.

Temporalização (semiótica) - Segundo Greimas \& Courtés (2008), a temporalização é um dos componentes da construção do discurso, junto com a actorialização e a espacialização. A temporalização é o processo de instituir e constituir as referências temporais do discurso, por exemplo como a definição de uma data específica no texto, ou a concomitância com a enunciação do discurso. Responsável pela atribuição do Presente - Passado - Futuro do discurso. 
Thread (internet) - Thread é um anglicismo utilizado para se referir coletivamente às respostas (replies) dadas por mais de um usuário dentro de uma Postagem, que pode ser feita em algum Fórum. Geralmente estas threads possuem uma dinâmica de "roda de conversa", pois costumam se tornar respostas de respostas, gerando linhas de discussão e assuntos paralelos.

Transmídia (Jenkins) - Segundo Jenkins (2009), uma narrativa transmídia é uma narrativa cujos trechos constituintes estão espalhados por mais de um meio de transmissão midiático. $\mathrm{O}$ termo transmídia se popularizou entre 2005 e 2012 como uma estratégia de marketing, e é aplicado também em jogos, como LOL e Overwatch.

Triangularidade (jogos) - É uma mecânica utilizada em diversos jogos de estratégia com diversos tipos de unidade descrita em 1982 por Chris Crawford, que se refere a uma relação cíclica em que as unidades de combate do jogo possuem a mesma série de atributos, e cada unidade possui alguns atributos fortes e outros fracos. A variação entre combinações de atributos entre as unidades garante que nenhuma unidade seja constantemente mais forte que as outras, e obriga o jogador a se utilizar de diferentes estratégias, dependendo de cada situação de jogo.

Trope (internet) - Trope é um termo corrente na internet, baseado na palavra Tropo, originária da tradição retórica, usada para nomear uma figura que modifica o sentido das palavras (Greimas \& Courtés - 2008), é considerado uma convenção, que um autor pode assumir como conhecido pela maioria dos leitores. No caso desta pesquisa, será considerado que tais tropes representam uma isotopia da cultura da internet, tal cultura será chamada de "manifestação cultural dominante", uma leitura de mundo a partir de um viés branco, heterossexual, machista, do hemisfério norte, ocidental, colonizador e anglicano.

Veridicção - De acordo com Greimas e Courtés (2008) é um "dizer-verdadeiro". Como na teoria linguística de Saussure há o princípio de imanência, em que o significado da mensagem não pode se basear em referenciais externos à mensagem, a veridiç̧ão consiste nas marcas presentes na leitura do texto, graças às quais o discurso enunciado é interpretado como verdadeiro ou não, produzindo um "efeito de verdade".

Virtuema (linguística) - De acordo com Pottier (1978), o virtuema seria um tipo específico de sema, que seria latente na memória associativa do falante, e cujo valor é dependente das 
circunstâncias socioculturais da comunicação. Ainda que a acepção original proposta por Pottier encontre discordâncias em estudos mais recentes, esta pesquisa propõe o uso do termo virtuema para definir os semas cuja existência depende do tecnoleto, fazendo referência à Forma Científica do tecnoleto.

Wikis (internet) - Wiki, uma palavra que significa "rápido" no idioma havaiano, é o nome dado a um tipo de website que pode ter seu conteúdo editado por usuários, desenvolvido inicialmente por Ward Cunningham em 1994. A maioria dos sites de wiki, tendo como exemplo maior a Wikipedia de Jimmy Wales e Larry Sanger, tem como principal objetivo servir como uma espécie de enciclopédia, reunindo o máximo de informação sobre um determinado assunto. No caso das wikis, geralmente a autoria é atribuída a um enunciador difuso, nomeado como a comunidade da internet.

XP (jogos) - Abreviação do termo em inglês Experience, costuma significar os pontos adquiridos pelos jogadores em partidas, necessários para que ele possa aumentar suas habilidades bem como

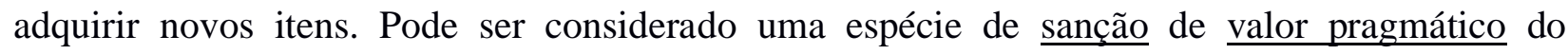
desempenho do jogador. 